EUR OPA PERSPECTIVES IN TRANSITIONAL JUSTICE

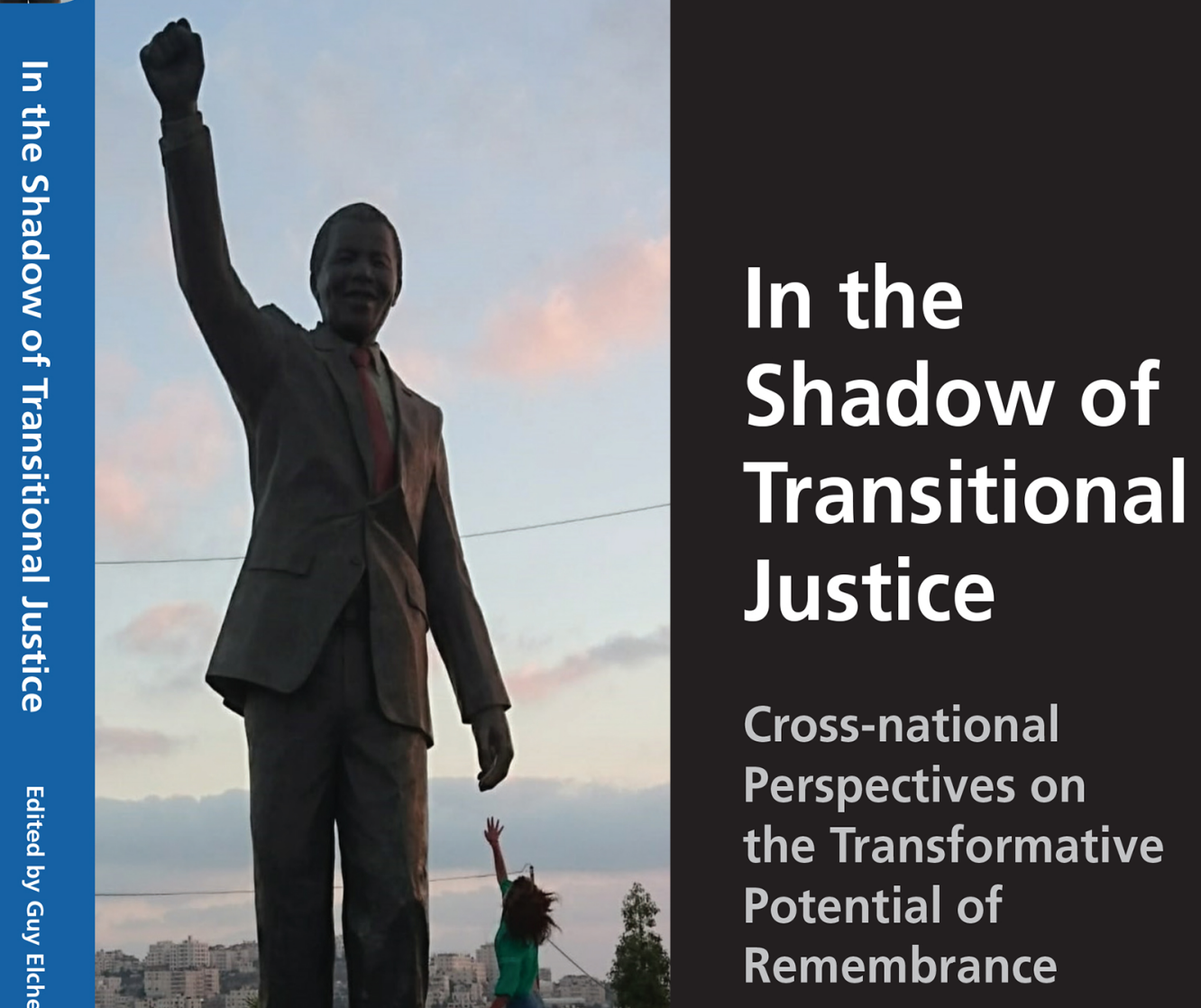
and Neloufer de Mel 


\section{In the Shadow of Transitional Justice}

This volume bridges two different research fields and the current debates within them. On the one hand, the transitional justice literature has been shaken by powerful calls to make the doctrine and practice of justice more transformative. On the other hand, collective memory studies now tend to look more closely at meaningful silences to make sense of what nations leave out when they remember their pasts. The book extends the scope of this heuristic approach to the different mechanisms that come under the umbrella of transitional justice, including legal prosecution, truth-seeking and reparations, alongside memorialization.

The 15 chapters included in the volume, written by expert scholars from diverse disciplinary and societal backgrounds, explore a range of practices intended to deal with the past, and how making the invisible visible again can make transitional justice - or indeed any societal engagement with the past - more transformative. Seeking to combine contextual depth and comparative width, the book features two key case analyses - South Africa and Sri Lanka - alongside discussions of multiple cases, including such emblematic sites as Rwanda and Argentina, but also sites better known for resisting than for embracing international norms of transitional justice, such as Turkey or Côte d'Ivoire. The different contributions, grouped in themed sections, progressively explore the issues, actors and resources that are typically forgotten when societies celebrate their pasts rather than mourning their losses and, in doing so, open new possibilities to build more inclusive processes for addressing the present consequences of past injustice.

Guy Elcheroth is Professor of Social Psychology at the Faculty of Social and Political Sciences, University of Lausanne, Switzerland, and Academic Director of the Lausanne Summer School on Transitional Justice and Conflict Transformation.

Neloufer de Mel is Senior Professor of English (Chair) at the Department of English, University of Colombo, Sri Lanka, and Co-director of the GCRF Gender, Justice and Security Research Hub. 


\section{Europa Perspectives in Transitional Justice}

The Europa Perspectives in Transitional Justice series from Routledge, edited by Professor Tim Murithi, provides a platform for innovative research and analysis of concepts, strategies and approaches to dealing with the past in deeply divided societies worldwide. The series encourages multidisciplinary scholarship on issues relating to reconciliation and how it is enhanced by efforts to promote redress and achieve socio-economic justice. The series aims to provide an invaluable resource for academics, policymakers, peace practitioners, researchers and all those interested in issues relating to addressing the deep-seated divisions within countries and communities. It also aims to propose forward-looking recommendations on how to achieve societal transformation.

The series comprises individual and edited volumes which provide analysis of transitions taking place at the global, regional and country levels, as well as engaging with thematic issues in the broad field of transitional justice and reconciliation.

Tim Murithi is Extraordinary Professor of African Studies at the Centre for African Studies, University of the Free State, and also Head of the Justice and Reconciliation in Africa Programme at the Institute for Justice and Reconciliation in Cape Town, South Africa. He has more than 21 years of experience in the fields of peacebuilding, governance, international justice and security in Africa. He sits on editorial boards and advisory panels for the Journal of Peacebuilding and Development, African Journal of Conflict Resolution, the Africa Peace and Conflict Journal and the journal Peacebuilding. He is author and editor of eight books; in addition he has authored more than 75 journal articles, book chapters and policy papers.

Truth, Justice and Reconciliation in Colombia: Transitioning from Violence Edited by Fabio Andrés Díaz Pabón

\section{Post-war Dilemmas of Sri Lanka}

Democracy and Reconciliation

S. I. Keethaponcalan

\section{In the Shadow of Transitional Justice}

Cross-national Perspectives on the Transformative Potential of Remembrance

Edited by Guy Elcheroth and Neloufer de Mel

For more information about this series, please visit: www.routledge.com/ Europa-Perspectives-in-Transitional-Justice/book-series/ECPTJ. 


\title{
In the Shadow of Transitional Justice
}

Cross-national Perspectives on the Transformative Potential of Remembrance

\author{
Edited by \\ Guy Elcheroth and Neloufer de Mel
}


First published 2022

by Routledge

2 Park Square, Milton Park, Abingdon, Oxon OX14 4RN

and by Routledge

52 Vanderbilt Avenue, New York, NY 10017

Routledge is an imprint of the Taylor \& Francis Group, an informa business

(C) 2022 selection and editorial matter, Guy Elcheroth and Neloufer de Mel; individual chapters, the contributors

The right of Guy Elcheroth and Neloufer de Mel to be identified as the authors of the editorial material, and of the authors for their individual chapters, has been asserted in accordance with sections 77 and 78 of the Copyright, Designs and Patents Act 1988.

Trademark notice: Product or corporate names may be trademarks or registered trademarks, and are used only for identification and explanation without intent to infringe.

The Open Access version of this book, available at www.taylorfrancis.com, has been made available under a Creative Commons Attribution-Non Commercial-No Derivatives 4.0 license.

British Library Cataloguing in Publication Data

A catalogue record for this book is available from the British Library

Library of Congress Cataloging-in-Publication Data

A catalog record has been requested for this book

ISBN: 978-0-367-76510-1 (hbk)

ISBN: 978-1-032-12835-1 (pbk)

ISBN: 978-1-003-16728-0 (ebk)

DOI: $10.4324 / 9781003167280$

Typeset in Times New Roman

by Taylor \& Francis Books 


\section{Contents}

1 Spotlights and shadows: revisiting the scope of transitional justice

GUY ELCHEROTH AND NELOUFER DE MEL

\section{PART I}

\section{Commemoration as celebration}

2 Celebrating the end of apartheid TIM MURITHI

3 Commemorating genocide in Rwanda ERIN JESSEE

4 Victory celebration and the unmaking of diversity in post-war Sri Lanka

PAIKIASOTHY SARAVANAMUTTU

\section{PART II}

\section{Forgotten issues $\quad 65$}

5 Social justice and the persistence of racialized segregation 67 KEVIN DURRHEIM AND AMY JO MURRAY

6 Intergenerational justice 79 ESTHER SURENTHIRARAJ

7 Non-citizens' rights: Xenophobia, nationalism and struggle post-transition 
vi Contents

\section{PART III}

Forgotten actors 105

8 Diaspora communities in transitional justice: A hidden presence 107 STEPHAN PARMENTIER, MINA RAUSCHENBACH AND LAURA HEIN

9 Rural women and their access to the law: Gendering the promise of post-war justice

NELOUFER DE MEL AND DANUSHKA MEDAWATTE

10 Former combatants: Assessing their reintegration ten years after the end of war

RAMILA USOOF-THOWFEEK AND VIYANGA GUNASEKERA

\section{PART IV}

\section{Forgotten resources}

11 Constructive resistance and the importance of not knowing in transitional justice

BRIONY JONES

12 Inclusive narratives of suffering

JOHANNA RAY VOLLHARDT, MICHELLE SINAYOBYE TWALI AND SUMEDHA JAYAKODY

13 How crowds transform identities YASEMIN GÜLSÜM ACAR AND STEPHEN REICHER

14 Collective resilience

SANDRA PENIĆ, JOHN DRURY AND ZACHARIA BADY

15 On the futures of reckoning with the past 


\section{Contributors}

Yasemin Gülsüm Acar is a Lecturer in the Department of Psychology at the University of Dundee, UK. She received her PhD from Claremont Graduate University, USA, in 2015, where she specialized in social identity and identity politicization through collective action. She has published numerous book chapters and articles on the consequences of collective action. She has also produced publications on various perceptions of the Kurdish-Turkish Peace Process in Turkey.

Zacharia Bady recently obtained a doctorate in social sciences from the University of Lausanne. His research focuses on the definition of collective identities in contexts torn by political violence or societal upheavals more generally. He has developed inductive survey methods designed to capture complex identity configurations that prevail in any given social context.

Neloufer de Mel is Senior Professor of English (Chair) at the Department of English of the University of Colombo, Sri Lanka. The author of Militarizing Sri Lanka: Popular Culture, Memory and Narrative in the Armed Conflict (2007) and Women and the Nation's Narrative: Gender and Nationalism in 20th Century Sri Lanka (2001), her recent journal publications and edited volumes have been on post-war Sri Lanka, providing feminist, postcolonial and cultural studies perspectives on questions of justice, post-war security and reframing democracy. She is a Co-director and Co-investigator at the GCRF Gender, Justice and Security Research Hub, has held several distinguished research fellowships at international universities and academic institutions including Yale, the Institute for Human Sciences, Vienna and the universities of Zurich and New York, and she has been the recipient of several research grants.

John Dixon is Professor of Social Psychology at the Open University, having previously worked at Lancaster University, UK, the University of Worcester, UK, and the University of Cape Town, South Africa. A former editor of the British Journal of Social Psychology, his publications include Racial Encounter: The Social Psychology of Contact and Desegregation (2005, 
Routledge), co-authored with Kevin Durrheim, and Beyond Prejudice: Extending the Social Psychology of Intergroup Conflict, Inequality and Social Change (2012, Cambridge University Press), co-edited with Mark Levine. He has also published numerous research articles on prejudice, intergroup contact and social change.

John Drury is Professor of Social Psychology at the University of Sussex, UK. His research focuses on collective behaviour - in protests, riots and social movements, in emergencies, and in less dramatic crowd phenomena such as at festivals, music and sports events. His findings on collective resilience in mass emergencies have informed the training of crowd safety managers and the UK Civil Contingencies Secretariat's National Risk Assessments. He is a former editor of the British Journal of Social Psychology.

Kevin Durrheim is Professor of Psychology at the University of KwaZuluNatal, South Africa, where he teaches social psychology and research methods and runs a research lab. He writes on topics related to racism, segregation and social change.

Guy Elcheroth is Professor of Social Psychology at the Faculty of Social and Political Sciences, University of Lausanne, Switzerland, and former Director of its Life Course and Inequality Research Centre. His research examines the links between collective shocks and collective resilience, the role of memories in the processes of conflict transformation, and the fate of critical voices in contexts of heightened nationalism. From 2014 to 2020, he led the Pluralistic Memories Project, an international consortium on the role of collective memories in armed conflicts. A member of several editorial committees, he has been Associate Editor of the Journal of Social and Political Psychology, and is the current Academic Director of the Lausanne Summer School on Transitional Justice and Conflict Transformation.

Viyanga Gunasekera is a Researcher at the International Centre for Ethnic Studies, Colombo, and is reading for an MPhil in Psychology at the University of Peradeniya, Sri Lanka. Her research has covered the psychosocial well-being of ex-combatants and pluralistic memories in post-war Sri Lanka. Currently, she is involved in studies that explore barriers to women's representation in politics, issues related to land and gender, and the social well-being of coastal communities.

Laura Hein is a doctoral candidate and teaching assistant at KU Leuven University - Leuven Institute for Criminology, Belgium, in the field of transitional justice and political crimes. Her $\mathrm{PhD}$ research focuses on the role of diaspora in transitional justice processes with Argentina as a case study. Her main areas of research interests are the links between transitional justice and forced displacement, the role of memory and acknowledgement of exiles' experiences and restorative justices approaches in 
transitional justice settings. She also works as a policy officer for the European Forum for Restorative Justice and contributes to the development and implementation of the organization's policy and advocacy work at both European and international level.

Sumedha Jayakody is currently finalizing his $\mathrm{PhD}$ at the University of Lausanne. His research investigates implications of asymmetric power, especially differing experiences of victimization on interethnic attitudes and behavioural outcomes relating to restorative and retributive justice in Sri Lanka.

Erin Jessee is a Senior Lecturer in History at the University of Glasgow, with over a decade of experience conducting oral historical and ethnographic fieldwork in conflict-affected settings, particularly Rwanda, BosniaHerzegovina and Uganda. She is the author of Negotiating Genocide in Rwanda: The Politics of History (2017), co-editor of Researching perpetrators of Genocide (2020) and has published several articles in notable journals such as Medical History, Memory Studies, Conflict and Society, History in Africa, Oral History Review and Forensic Science International, among others.

Briony Jones is Associate Professor of International Development at the University of Warwick, UK. Her research takes place at the intersection of transitional justice, peacebuilding and development. She specializes in the politics of societies following large-scale violations of human rights, and in particular on the issues of resistance, citizenship and the politics of knowledge. She is Deputy Director of the Warwick Interdisciplinary Research Centre for International Development, Co-chair of the Human Rights and Transitional Justice Standing Group of the European Consortium for Political Research, and a member of the Working Group on Sustainable Development Goal 16 and Transitional Justice.

Philippa Kerr is currently a Postdoctoral Research Fellow affiliated with the Psychology Department at Stellenbosch University, South Africa. She has a $\mathrm{PhD}$ in Psychology from the University of KwaZulu-Natal, and has published research on xenophobia in South Africa, as well as on the casualization of academic labour. She is also an artist and musician.

Danushka Medawatte is a Senior Lecturer at the Faculty of Law, University of Colombo. Since 2012, she has worked with Sri Lankan women affected by the armed conflict. She is currently leading the drafting of the National Action Plan on Women, Peace, and Security on behalf of the State Ministry of Women and Child Development, Sri Lanka. She is a Co-investigator at the GCRF Gender, Justice and Security Research Hub. She has an LLB (Hons) and an MPhil from the University of Colombo and an LLM from Harvard Law School, USA.

Tim Murithi is Head of Programme at the Institute for Justice and Reconciliation in Cape Town and Extraordinary Professor of African Studies at 
the University of Free State in South Africa. He has 25 years of experience in peace, security, governance, transitional justice and development in Africa and has held positions with the United Nations Institute for Training and Research, Geneva, Switzerland; the Institute for Security Studies, Addis Ababa, Ethiopia; the Department for Political Studies and Centre for Conflict Resolution, University of Cape Town; the Nordic Africa Institute and the Department of Peace and Conflict Research, Uppsala University, Sweden; and the Department of Peace Studies, University of Bradford, UK. He has written over 100 journal articles, book chapters and policy papers. He is the author and editor of 11 books, including The Ethics of Peacebuilding (2009), The African Union: PanAfricanism, Peacebuilding and Development (2005), the Routledge Handbook of Africa's International Relations (2014), and The Politics of Transitional Justice in the Great Lakes Region of Africa (2016). He is the General Editor of the Routledge Europa Series on Perspectives in Transitional Justice.

Amy Jo Murray is a Researcher based at the University of KwaZulu-Natal. She is exploring innovative ways of understanding social justice and inequality through qualitative research. She is studying the unsaid within racialized relationships, specifically within paid domestic labour.

Stephan Parmentier teaches the sociology of crime, law and human rights at the Faculty of Law of the University of Leuven, and coordinates the Research Line on Human Rights and Transitional Justice at the Leuven Institute of Criminology. He also serves as Chairperson of the Interfaculty Council of Development Cooperation at the University of Leuven, as Vice Dean for International Relations at the Faculty of Law and is a member of the university-wide Ethical Commission on Dual Use, Military Use \& Misuse of Research. He has been the Secretary-General of the International Society for Criminology since 2010, and for many years has also been a member of the Advisory Board of the Oxford Centre of Criminology and of the International Centre for Transitional Justice (New York, USA, and Brussels, Belgium). He is the founding General Editor of the Series on Transitional Justice (Intersentia Publishers, Cambridge/ Antwerp), and the founding editor of The International Journal of Restorative Justice (Eleven Publishing, The Hague). He has published widely on transitional justice, human rights, restorative justice and peacebuilding, and has conducted fieldwork in Bosnia/Serbia, Central and Southern Africa, and Central and South America.

Sandra Penić is a Lecturer at the University of Geneva. Her research focuses on political violence. She studies the impact of mass exposure to political violence on intergroup attitudes, emotions and psychological well-being in different conflict-torn societies. 
Mina Rauschenbach holds a PhD in Social Sciences (University of Lausanne) and is a Lecturer at the Institute of Social Sciences of the University of Lausanne, as well as a Research Associate at the Leuven Institute of Criminology (University of Leuven/KU Leuven). Her main areas of research interest concern the role of victimhood in collective understandings of the past and how they shape different stakeholders' (e.g. victims, perpetrators, citizens, diaspora communities) justice perceptions and beliefs in the aftermath of serious human rights violations. She is General Editor of the Series on Transitional Justice (Intersentia Publishers, Cambridge/Antwerp).

Stephen Reicher is Wardlaw Professor of Psychology at the University of St Andrews, UK. He is Vice President of the Royal Society of Edinburgh, a fellow of the British Academy, a Fellow of the Academy of Social Sciences and a Fellow of the Canadian Institute for Advanced research. His work is on group processes, addressing the relationship between social identities and collective action.

Paikiasothy Saravanamuttu is the founding Executive Director of the Centre for Policy Alternatives in Colombo, and he was the Secretary to the country's Consultative Task Force on Reconciliation Mechanisms in 2016-17. He holds a PhD in International Relations from the London School of Economics and Political Science, UK, and lectured in International Politics at the University of Southampton, UK, from 1984-92. He was the winner of the inaugural Citizens Peace Award in 2010 and has been nominated for a number of international peace prizes.

Esther Surenthiraraj is a Lecturer in the Department of English, University of Colombo. She holds a PhD in Social Sciences from the University of Lausanne. She has also been trained in English (Language and Literature) and Linguistics. Engaged in interdisciplinary research work, she employs discourse analysis as a primary mode of analysis across a range of topics. Her current interests are memory, narrative, identity and rhetoric in Sri Lanka.

Michelle Sinayobye Twali received her PhD in Social Psychology from Clark University in Massachusetts, USA, and is currently a postdoctoral fellow at Princeton University and Innovations for Poverty Action. Her research has mostly investigated the ways in which victim groups make sense of their experience, and how this meaning-making influences their well-being, their attitudes and behaviours towards their in-group and other groups (the perpetrator and other victim groups), and their support for or opposition to relevant policies.

Ramila Usoof-Thowfeek is Senior Lecturer in Psychology in the Department of Psychology, University of Peradeniya. After completing her doctoral degree in Psychology (specializing in the psychology of peace and violence) at the University of Massachusetts, Amherst, USA, she has worked 


\section{xii List of contributors}

on topics related to the post-war realities in Sri Lanka, including the psychosocial well-being of communities in the north and east of Sri Lanka, social identities and development, and collective memory. She has also been involved with several non-governmental organizations, such as the International Centre for Ethnic Studies, Colombo, the World Bank and the United Nations Development Programme, in conducting this work.

Johanna Ray Vollhardt is an Associate Professor of Psychology at Clark University, where she directs the Social Psychology PhD programme and is also affiliated with the Strassler Center for Holocaust and Genocide Studies, the Peace and Conflict Studies concentration, and the Center for Race, Gender, and Area Studies. Her research focuses on how people make sense of their group's collective victimization and oppression, and related issues such as resistance in repressive and violent contexts, groupbased power, and acknowledgement. She received the Dissertation Award and Early Career Awards from the International Society of Political Psychology and is a founding Co-editor of the Journal of Social and Political Psychology. 


\section{Spotlights and shadows: revisiting the scope of transitional justice Guy Elcheroth and Neloufer de Mel}

\section{Transitional justice at a crossroads}

There are two different ways of answering the question "what is transitional justice?" The first focuses on what differentiates transitional justice, in principle, from other human activities meant to respond to injustice and crime. From this angle, two elements can be seen as critical to the definition of transitional justice. On the one hand, it occurs in societies that are in some way over-burdened by a past legacy of systemic injustice, generally to a degree that would impair social life and the functioning of institutions in manifold ways. On the other hand, it refers to forms of justice that can only be delivered when such societies have reached a turning point at which previously closed opportunities for dealing with a criminal or oppressive system become open, most typically after the toppling of an authoritarian regime or the end of war. In that view, transitional justice is largely defined by its historic context. The Nuremberg trials can be considered as (pioneering) examples of transitional justice not only because of the Nazi regime's scope of atrocity, but also because Nazi Germany had been defeated when the trials took place. The South African Truth and Reconciliation Commission (TRC) is generally seen as an emblematic case of transitional justice, not only because of the horrendousness of the racist crimes institutionalized by the apartheid regime but also because it was instituted in the wake of the legal abolishment of apartheid and of democratic elections bringing to power a previously oppressed majority.

The second way of answering the definitional question focuses on what is typically done in practice under the banner of transitional justice. From this perspective, transitional justice is mainly defined by the particular type of mechanisms that have been implemented historically to address past injustice. At the heart of such a definition one can identify a triangle of mechanisms which foreground dealing with either perpetrators, victim-survivors or the system: prosecution, reparation and truth-seeking. These are often complemented by a second triad of mechanisms aiming to prevent reoccurrence, through changing institutions, elites or ideologies: reform, lustration and memorialization. From this view, the Nuremberg trials were transitional

DOI: $10.4324 / 9781003167280-1$ 


\section{Guy Elcheroth and Neloufer de Mel}

justice simply because they were war crimes tribunals, and the South African TRC because it was a truth commission. Such a working definition potentially broadens the scope of transitional justice, as political transition becomes a secondary criterion - or defined circularly, as transition to a situation where there is sufficient political will to institute a given mechanism. In this view, a political decision to "belatedly" tackle a so far unaddressed legacy, such as Belgium's recent decision to create a special commission to examine its colonial past (Ponselet 2020), or a "premature" move to address crimes in the midst of open violence - as with the creation of the International Criminal Tribunal for the former Yugoslavia in 1993, while war was still raging in Croatia and Bosnia - can also be seen as transitional justice, as long as the way of dealing with misdeeds draws on transitional justice's cumulative toolkit.

However, a recent wave of debate in the field further complicates the picture. The crux of current discontent within an important part of the transitional justice community of scholars and practitioners lies with the recurrently observed failure of key mechanisms to trigger systemic change, to deliver on social justice or to tackle deep sources of violence, suffering and conflict rooted in economic structures (see Gready and Robins 2019). This debate is based on the understanding that "transitional justice is in crisis" (Gready 2019, p. 1) and has led some observers to wonder whether a "schism" is in the making in the field (Balasco 2018), between sceptics and enthusiasts of its transformative turn. For the latter, the quality of social change achieved in effect through a transitional justice process is a more central concern than the intrinsic qualities of the means mobilized. This approach appears, hence, to open the door to a third type of definition, focusing more on the grand objectives of any transitional justice process than on the type of mechanisms it institutes. What matters most in this view is the transformative ideal a society is capable of moving towards: minimally, to become more resilient and to prevent further outbursts of violence; more ambitiously, to become fairer and to overcome systems of oppression. Such a focus on "transformation" also further relativizes the importance of "transition": sometimes this notion is even seen as being part of the problem, as it focuses on a particular historical moment, rather than on chronic, long-term patterns of oppression.

In short, the transformative current proposes a new vision of what transitional justice should aspire to be. Doing so, it may be blurring the lines - or revealing disagreement - about its specific contribution to a much broader field of practices that work towards greater social justice. (What else can transitional justice offer to the wider field, if not the idea that engagement with the past during political turning points can be a powerful pathway to change?) It raises the question whether transitional justice's traditional focus on the extraordinary - on extraordinary circumstances following authoritarian regimes or armed conflict and on extraordinary tools such as special jurisdictions, ad hoc truth commissions or reparations for specific groups of 
victims - has become both its main strength and its main weakness. What space can be given to shake "ordinary" forms of oppression or to attune "ordinary" forms of suffering within a "limited mandate" for transitional justice? Will it still be possible to reconcile the renewed focus on dismantling oppressive structures spanning from the past into the present, and the progressive values underlying this focus, with the tools that decades of transitional justice practice and research have left us with?

\section{Societies caught in transition: when justice is postponed}

The fact that transitional justice can be strong when facing the extraordinary, but weak towards the ordinary, implies that its brilliance sometimes fades with the passage of time. South Africa is certainly emblematic of these two faces of transitional justice. While the country's experience has often been referred to as an exemplary demonstration of what a truth and reconciliation process can achieve, and while it has shaped the field's "global norm" (BenJosef Hirsch 2014), today it anchors the most influential critiques of the same norm (Gready 2011; Evans 2018). Apartheid has disappeared in law, but segregation and racial inequality remain as an enduring social reality in urban landscapes and in the daily experiences of South Africans (Dixon and Durrheim 2003; Evans 2016). If the focus is on social transformation, retrospectively, the South African TRC might be seen as a weak form of transitional justice, in the sense that it has not set in motion profound changes to the social and economic structures which sustain racial inequality. In a context where change has been fought for and has been celebrated, but then never realized at the promised scale, different aspects of social life appear frozen while the past does not go away. The experience of racial inequality but also the rhetoric of struggle - reoriented against new targets (Kerr et al. 2019) are both persistent and blurred.

To be fair, however, we don't know what kind of society South Africa would be today had there been no truth process in the 1990s. In Palestine, where the experiment of a peace process without a truth process addressing past violence and collective expulsion was launched during the same period, a regime of formal segregation is in place today, with a complex web of territorial fragmentation, permit systems, separate roads, military checkpoints and the fence that Palestinians call the "apartheid wall". Within and outside Palestine, Palestinian refugee camps display dramatic instances of the paradox of a transient situation that lasts, and of a language of struggle, of martyrs and heroes passed down over generations together with the memories of the lost places and a non-enforced right to return (Khalili 2007).

\section{Triumph and trauma: when commemoration becomes invasive}

It is more than a bitter historical irony that the state that is currently holding the reins of this institutionalized system of segregation is itself born out of 
unimaginable atrocity. Klar et al. (2013) have analysed Israel's treatment of the Holocaust, from an earlier period of silence to the current reality of everpresent commemoration - in the daily news, books, classrooms, remembrance days and organized trips to Poland's death camps. While all of these commemorative activities gravitate around the moral imperative of nonreoccurrence, there is more than one way to understand the lessons of history and more than one meaning of "never again": from never again letting catastrophe happen to the Jewish community, to never again accepting cruelty inflicted on any human community. In present-day Israel, these different voices are not equally strong, and are not equally sustained by state institutions. The Israeli case therefore illustrates that, while collective trauma can contain the seeds of its non-recurrence, eventually the lessons learned depend on what exactly is seen as needing to be avoided and hence, not least, on the nature of the state and regime that channel the commemorative energy.

Rwanda is arguably the most far-reaching contemporary experiment with transitional justice. Mechanisms unprecedented in their range and scope have been implemented in response to the horrendous tragedy of the genocide committed in 1994. These include a special international criminal tribunal and local Gacaca tribunals, a reorganization of the state and legislation to eradicate the institutional roots of genocide, as well as massive memorialization projects to tackle its ideological roots, and entrench the "never again" imperative. The sheer number of people involved in different roles bears no comparison, with the number of accused génocidaires, witnesses and even local Gacaca judges being counted in the hundreds of thousands (McKnight 2014), while the annual 100 days of mourning have become an inescapable commemorative routine for the country's 12 million inhabitants. As in the case of South Africa after apartheid, these massive efforts could not have been deployed without the required political will. Similarly to Nelson Mandela's African National Congress, the party and regime led by Paul Kagame is imbued with a twofold historical legitimacy in Rwanda after the genocide: as representatives of the historic victims and as leaders of an eventually victorious struggle against the previous criminal regime.

Rwanda seems, hence, an interesting place to look for how a transitional justice experiment can transform a society when it is delivered top-down by a voluntarist state power and is designed to infuse all spheres of social life. Research from different fields has revealed a range of worrisome side-effects of such collective state-enforced "treatment". Psychologists have warned against the re-traumatizing effects on survivors and witnesses (e.g. Brounéus 2010), anthropologists against the diversion of justice to serve individual or collective agendas (e.g. Burnet 2008) and political scientists against the blurring of power relations when idealized "local" forms of justice are manipulated by overhanging state actors (Kochanski 2020). What seems to hold these apparently disparate problems together is the underlying "danger of a single story" (Jessee 2017): the narrowing down of complex stories about past violence to one pre-eminent and tightly monitored narrative. Today, it is 
possible that many Rwandans are psychologically, socially or politically insecure not because of a lack of engagement with the past, but because they struggle to integrate their own experiences, concerns or aspirations with the regime's overarching call for remembrance, instituted as a moral, social and even legal imperative.

But, again, it seems unfair to judge the impact of transitional justice without looking at societies where there is no full-hearted attempt to hold perpetrators accountable or to memorialize the collective trauma. In Sri Lanka, the military victory of the government forces over the rebel forces, in 2009, not only brought to its end an almost three-decades-long civil war, but also opened a boulevard for a triumphalist, state-led narrative on the war, which left little space to mourn losses, especially among the Tamil minority which bore the highest toll during the brutal ending of the fighting. Victory monuments were built throughout the country - including near sites where countless civilians were trapped during the latter stages of the war - and Sri Lankans from the south of the country were "toured" into the war sites in the north, to be told the government's tale of war and victory against terrorism (Hyndman and Amarasingam 2014). At the same time its former opponents, the Liberation Tigers of Tamil Eelam, were wiped out in the country, through the elimination of its leaders during the final offensive, the "rehabilitation" of its surviving, lower-ranked combatants and the removal of its military cemeteries. Keeping intact sites to mourn the losses - even modest and informal - has become a risky operation within the country, and remaining attempts to preserve the memory of the struggle are sometimes displaced to the diaspora (Orjuela 2020). In this context of post-war triumphalism, an emboldened Sri Lankan government has made resistance against a "global norm" version of transitional justice a part of its heroic narrative to defend national sovereignty against both terrorism and Western interference (Parasram 2012).

\section{Disenchantments, new expectations and the scope of transitional justice}

To recap, transitional justice has become an inherently controversial project, contested on multiple grounds. On the one hand, it is opposed by those who worry when it goes too far, permeating social life with an inescapable duty to remember, and on the other hand by those who are disappointed when it does not go far enough, and provides only symbolic or exceptional justice where chronic injustice remains. Furthermore, it has become a target for those who denounce the double standards of the international community and see the global norm as a Western norm, as an ideological justification to the promotion of Western geopolitical influence.

Notwithstanding these critiques, there are concurrent calls to further expand the scope of transitional justice to the most pressing unresolved problems of our times. When African nations call for an international investigation into systemic racism in the United States on the backdrop of its 
unaddressed history of slavery (Human Rights Council 2020), or when the European Union, in its current anti-racism action plan, responds to the Black Lives Matter movement by encouraging a critical re-examination of Europe's colonial history (European Commission 2020), the intellectual heritage of transitional justice is clearly discernible. More creatively, some scholars are mobilizing a transitional justice lens to fight against global warming and its consequences, by addressing the historical roots of current obstacles to climate justice (Klinsky and Brankovic 2018), or by designing a framework for reparative justice for climate refugees (Buxton 2019).

All in all, it seems that transitional justice has become a site of both recurrent disenchantments and new hopes. With this book, we aim to take both seriously, recognizing the good reasons underlying disenchantments and hopes. But the book is also rooted in something more. Something that runs through the history of transitional justice as a red thread, underlies its bright and dark sides, and helps to make sense of the formidable - sometimes excessive and unrealistic - expectations placed on transitional justice as well as of dreams that turn sour: our collective intuition of the world-making force of remembrance.

Memories can be our prisons, but sometimes they pave the ways out of them. Transitional justice processes are typically high-stakes events, which crystalize strong advocacy and resistance, not only because they can send to jail high-profile leaders, or better the living circumstances of those recognized as victims of criminal systems, but also because a society that accepts to revisit its past potentially remixes the cards for what becomes possible (or impossible) in the present. Forced after World War II to look deeply into its own moral abysses, German society had symbolically closed doors to certain forms of political and military organization for its post-war generation, and cleared the way to a new constitutional democracy. This process created winners and losers, but it was able to draw on a then consensual set of values and worldviews. But to what extent does remembering our collective pasts affect how we organize and act together, and why does it often result in entrenching the social status quo, while at other times turning it upside-down?

\section{Can remembrance change societies?}

If we want engagement with the past to be a lever for change, then what we remember from the past needs to be more than what the powerful and the victorious retain and celebrate. To be clear about that point, it is helpful to disentangle notions that are sometimes used in a loosely overlapping way, such as remembrance, commemoration or celebration of the past. Commemoration can be thought of as a socially instituted form of remembrance - often orchestrated by nation-states - while celebration stands for a triumphalist form of commemoration, which foregrounds victory, virtue and vindication. The examples alluded to in the previous section call to mind what can happen when remembrance is reduced to commemoration, or when 
commemoration is reduced to celebration. But they should not lead us to overlook the fact that commemoration can also be more than celebration, and remembrance more than commemoration. It is therefore important (and, indeed, a primary motivation for this book) to clarify why non-celebrative forms of commemoration are essential for reimagining social life during periods of transition, and how non-commemorative forms of remembrance provide the creative building blocks for such an undertaking.

\section{Selective silences: worlds built on oblivion}

When opening their monograph dedicated to formal commemorations of the 1974 Portuguese Revolution, Billig and Marinho (2017, pp. 3-4) warn readers about what they do not aim to do:

Works about collective memory often examine texts and speeches in order to extract and then reconstruct a group's shared, or contested, collective representations of its past. We could have done this. It would have been possible to pore over the ceremonial speeches, extracting hints about the memory of 25 April and then collecting these hints together to form a pattern that we then claim to be 'the Portuguese collective memory or memories' of the revolution. If we did this, we would be acting like the police inspector who overlooks the obvious absence. In our desire to find the shared memory, we would run the risk of failing to notice how little direct remembering is going on in these ceremonial speeches.

Instead of searching for "the memories" in the solemn words and phrases pronounced by leaders during commemorative speeches, or in their grand symbolic gestures, Billig and Marinho set out to "look for absences" and, this way, were able to highlight some notable patterns of meaningful silence. Across the political spectrum, parliamentary speakers have commemorated the events of 25 April 1974 "forgetting" to mention what concretely happened on that date - past its mythicized dawn, when the captains were joined by the people in the streets of Lisbon - or what General Spinola, who became the new republic's first president, did during the day. Despite the solemnly displayed national unity, they would also systematically "forget" to applaud the words of their political opponents. Most conservative politicians would, moreover, "forget" to decorate their buttonholes with a red carnation - not only the commemorative symbol of the popular revolt, but also a reminder of its socialist inspiration.

To literary scholars, Billig and Marinho's approach might ring a bell. Pierre Macheray, in his classic Theory of Literary Production, wrote:

The speech of the book comes from a certain silence, a matter which it endows with form, a ground on which it traces a figure. Thus, the book 
is not self-sufficient; it is necessarily accompanied by a certain absence, without which it would not exist.

(p. 85, emphasis added)

But making sense out of silence might prove enlightening well beyond the realm of books, scripted texts or solemn commemorative speeches. The social worlds surrounding us - if we dare to use the oxymoron - are filled with absences, which can prove heavily meaningful when set in their relevant context. Selective forgetting happens when families talk or don't talk about their country's colonial past (Licata and Klein 2010), when archivists decide which documents to conserve in a national archive (Millar 2006) or when we share our most memorable life events with other people (Pasupathi et al. 2009). It filters what we retain from intimate experiences and from social crises, and it holds together our national narratives, from their most mundane (Billig 1995) to their most aggressive and militant expressions (Ramanathapillai 2006, 2012).

\section{Truth, memory and the quest for shared reality}

From a strictly logical point of view, the phrase "selective memories" comes close to a pleonasm. Memories simply are what we retain, for a given period, from a potential infinity of events, experiences or sensations, and there is no plausible reason to expect such selection to occur "randomly", in the way that statisticians use the term: with equal chances of selection given to each instance. The idea of living every moment of our individual or collective existence with the cumulative legacy of anything ever experienced beforehand seems logically and psychologically untenable. It furthermore makes sense to expect that some good reasons are at play when we keep certain memories and unburden ourselves from others. But, as there can be a plurality of good reasons potentially in conflict with each other, the critical question is: what makes certain good reasons outweigh others, or when it comes to collective remembrance, what makes some people's good reasons prevail over those held by others?

The examples given in the previous section suggest that, for experiences that can either be forgotten or remembered in societies confronted with their troubled past, there is always an underlying political dimension. The "good reasons" of leaders, state representatives or militant challengers to favour certain memories over others appear often relatively easy to infer, once we have a good enough idea of the past involvements, current interests and future agendas of specific actors. The more complex and less well understood part of the process lies with larger groups of people, and with the questions of when and how they align their memories with those of particular political leaders, especially when there is no perfect match between elites and people's involvements, interests and agendas.

To grasp what is at play in these collective processes, we first need to be clear about one thing: the fact that there are specific reasons why certain 
things are remembered and others forgotten does not imply that the process is fully deliberate, i.e. that we only remember what we want to remember. We also need to have a chance to remember. It is sociologically and psychologically well established that "memories" are not like inert things that can be put away and stored somewhere to be preserved. The only chance for our memories to survive is that we practise them: we remember by rehearsing. We retain a memory by spending time thinking about it, by telling it to someone, by writing it up, singing it, crying it or playing it. Therefore, when stripped of sufficient opportunities to do any of these things, we will, sooner or later, loose a memory. Another consequence is that each time we tell, write, sing, cry or play a memory, we do more than simply keep it alive: we give it new life. The memory is not simply preserved, it is re-elaborated and transformed - potentially enriched of certain qualities and impoverished of others - each time we remember.

The critical point for understanding the relationship between remembrance and social change is that we are seldom alone in these transformative moments. Two decades of research into the social psychology of remembrance suggest that "not being alone" when remembering might actually be a pre-condition both to keeping a memory alive and to transforming it by sharing it. Two telling experiments help to make this point concrete. In one experiment, Pasupathi, Stallworth and Murdoch (1998) showed short movie excerpts to research participants and then asked them to recount some of the clips they had seen to someone else. The clips were actually randomly allocated to three different types of treatment: for some clips, the person to whom a research participant retold the movie content was instructed to do nothing other than to listen attentively; for other clips (s)he was distracted by a different task while listening; while the remaining clips were not recounted at all. When asked to recall the content of the movie excerpts three weeks later, research participants proved able to provide significantly more details for those clips that they had been given an opportunity previously to relate to someone who was actively listening. Interestingly, distracted listeners were of no help: as many details were forgotten from the clips recounted to someone displaying no signs of genuine interest as from the clips that were not retold at all. These findings suggest, therefore, that we remember better what we are able to share: remembering is a social practice, not something that can be done effectively in isolation, or without the sense of a meaningful social exchange.

In another noteworthy experiment, Marsh (2007) was interested not so much in how detailed or accurate memories are depending on the social circumstances, but rather in how they are transformed by being shared. She asked research participants to read a story, then to retell it with a specific purpose (either to recommend the main character or to complain about him/ her) and, finally, to recall the original story as accurately as possible. As a result, in the final recall, participants tended to forget elements from the original story that were incongruent with the purpose of their own previous 
retelling of the story, and they added elements (not present in the original story) that were congruent with this purpose. This finding led Marsh to speculate: "What people remember about events may be the story they last told about those events" (p. 19, emphasis added).

Subsequent studies have reached similar conclusions. Some authors have gone further in theorizing the underlying motives and mechanisms through which our memories change. Echterhoff et al. (2009) have highlighted our epistemic and social need to live in a shared reality as a driving force. Most facets of our lives unfold in a social world that $i$ s the world we share with others and upon which we can act jointly. Being unable to live in a shared reality breeds isolation, helplessness and estrangement. As a consequence, we invest effort in keeping intact a sense of shared reality by selecting and accommodating what we share with others to what we anticipate they will be able to hear and recognize as true and as relevant. But there is also an internal side to the process: we tend to remember our experiences in the way we've shared them. Our stories become our memories and what we can't turn into "good stories" - stories others will listen too attentively - is doomed to oblivion.

Those who control state power can pull a variety of strings that shape opportunities to share stories publicly and position them as "good stories" that are worthy of being widely heard and rehearsed. But no state is almighty, and the spaces to share stories are negotiated at multiple scales. For example, Di Pasquale (2012) has studied a small mountainous village community, in the Italian region of Tuscany, that has managed to keep alive, over a period of 60 years, a locally shared memory of a World War II massacre, despite a policy of forgetting and impunity pursued by state authorities, until their memories were finally sanctioned by a belated trial of the Nazi officers responsible for the atrocity:

The survivors and the relatives of the dead have constructed their memory around their own cognitive and cultural horizons. They have crystallized their experiences, integrated personal stories with details of everyday local life and linked this collective representation with relevant information from the outside. In this way, the subjectivities of mourning have formed a mnemonic community defined by continual recollection of their wartime past. This means that the Nazi violence has affected the entire social group: none of the members has been able to forget it, even if not all of them have wanted to deal with it.

(p. 501)

\section{Scales of transformation}

So far, we have referred rather loosely to processes that play out at the most contrasting levels of human experience: from the intimate process of remembering to the "global norm" of transitional justice, with community and state levels in between. In our current world of nations, how a process of 
transitional justice becomes instituted at the national level is often particularly consequential and the question as to what international actors can and should do to facilitate the occurrence of such a process is typically of particular pragmatic relevance. This question is tied, however, to difficult unresolved problems, both normatively and analytically.

Normatively, there is the question of what legitimacy "foreign" actors have to influence a domestic process. As alluded to already with the Sri Lankan example, state actors facing international pressure are often eager to point out their own democratic legitimacy and the principle of national sovereignty, and to denounce external human rights claims as power politics conducted under a moral guise. Friction between international and local actors accusing each other, respectively, of "interference" and "spoilerism", might be more typical than harmonious cooperation and converging objectives (e.g. Höglund and Orjuela 2013). In this context, recent voices have warned against romanticizing local communities' roles in transitional justice, as they often become the sites of competition between domestic and international actors, where either side refers to local practices, traditions or aspirations to further their own agendas and project their own understanding of coming to terms with the past (e.g. Kochanski 2020).

Thorough and controversial ethical debates certainly remain necessary in this field, as there will never be a neutral perspective from which to judge the legitimacy of different actors entering into friction with each other in the global system. But these debates might remain fruitless so long as they are guided by abstract and idealized notions of the "national community" or of the "international community". It is important therefore to look at specific groups of actors that have a stake in the process and to wonder to what extent their perspective and interests are, and can be, concretely represented by entities such as state institutions or international organizations. For example, what justice can defeated groups or minority communities expect from the nation-state when state institutions are controlled by the majority? What effective access do groups that occupy a peripheral position in any given social structure have to formal justice?

Analytically, there is the question of how complex processes that intersect across different scales end up making a difference in practice. A simple political analysis of key actors' interests, power calculus and resources risks falling short of processes that are also about emerging dynamics, unintended consequences and shifting social ecologies. Political power is always contingent upon the capacity to mobilize support and shape collective action: even in the most coercive authoritarian regime, the question remains, for example, at what point people expect that others will follow orders and that those who disobey will be punished. Moreover, social groups and social systems generally do not come out of periods of collective violence as they have entered them (Elcheroth and Reicher 2017). What is valuable - and hence defines collective and individual interest - changes in the face of collective trauma (Spini et al. 2019), or during the very process of addressing 
past crimes (Rimé et al. 2011). Sometimes new groups emerge out of violence (e.g. Thiranagama 2013). Often, intergroup configurations shift entirely, when previous alliances break up or new alliances are created, or when previously passive third parties become actively involved (Dixon et al. 2020). Such complex dynamics and moments of unpredictable change are sometimes feared as potential roads to chaos, but they also sow the seeds for progressive social change (Drury 2018). In moments of transition, small differences can have large consequences when one change triggers the next, in a cascading sequence of events. Social change is not decreed top-down, but well-timed policy initiatives can take an emergent movement beyond a specific tipping point (see Nyborg et al. 2016). If the success of transitional justice is to be measured at its capacity to be transformative, it becomes important to judge any transitional justice process not only by its internal procedures, but also by the way it interacts, at a specific place and time, with collective resources set in motion locally and globally. The oversights of transitional justice with the most far-reaching consequences might be those that "forget" that resources such as potential allies for justice, changing collective values or facilitative "stocks" of common experiences are available, where and when they are.

\section{Exploring the shadows}

At this point, a range of reasons why we aim to revisit transitional justice from its shadows might have transpired. We do not only borrow the idea from Billig and Marinho, and Macherey, that omissions - what is not shown, said or remembered - can be meaningful, but also anticipate that by shifting our gaze away from what is actively lit to what is rendered more difficult to see, we can learn something useful about demobilizing delusions, missed opportunities or unexplored possibilities. To recap with examples from two sites already alluded to, which will be deepened throughout this book: in South Africa, deep economic injustice and racial segregation never went away, but might have been temporarily more difficult to see, during the postapartheid "honeymoon" period. In Sri Lanka, internally displaced communities have been caught in transient spaces over periods long enough for new generations to grow up as so-called refugees, but largely moved out of sight for the country's dramatic end of the war and triumphalist transition to the new post-war era. Other examples of questions raised by typical oversights that merit closer scrutiny are: what is overwritten when a state celebrates the "rehabilitation" of the combatants it has just defeated? Or, which experiences are implicitly accepted for marginalization when transitional justice is delivered nationally, while many armed conflicts or repressive regimes around the world have also produced generations of forced exile communities?

While we believe in the relevance of critically questioning the effective contribution of existing transitional justice processes for creating more fairness and less suffering in the long term, we do not want to throw the baby 
out with the bathwater. Setting in motion processes of "transformative justice" is certainly a laudable objective in many circumstances, but affirming this objective does not remove the need for societies that have been confronted with injustice and suffering at an extraordinary scale to find extraordinary means to deal with their past - and to seize windows of opportunity for doing so during periods of political transition. Rather than shelving the historic "toolkit" that several decades of societal experiments with transitional justice have left us with, we therefore suggest looking at this collective legacy from new angles, in order to reimagine its transformative power.

\section{Joint aims, plural approaches: how 15 original angles make a book}

To find these new angles, we have prioritized out-of-the box thinking and proceeded in a somewhat unorthodox manner. Most of the scholars who look into the shadows of transitional justice here are not specialists on transitional justice. This means that - several notable exceptions apart - most contributors to this collective volume did not make a career studying, let alone implementing, transitional justice mechanisms, but come from a broad range of different research fields. It also means that many of us have been trained originally in disciplines not seen as core to the transitional justice community, such as social psychology, oral history, anthropology, cultural or gender studies - while law, criminology and political science are not absent. But we all have in common a marked interest and years- or decades-long research experience with problems of social justice, collective action, social trauma, collective remembering and/or history writing.

There is still something else that binds together the different contributors: a joint involvement in an international doctoral training initiative - initially as part of the Pluralistic Memories Project, before it became the Lausanne Summer School on Transitional Justice and Conflict Transformation - as lecturers, participants or organizers. This common involvement has facilitated, over the years, the development of common references and a culture of dialogue between scholars with different sensibilities, rooted in different societal and disciplinary backgrounds. When the project to write a collective book arose and concretized, this culture of exchange was further nurtured through author-editor brainstorming meetings, original co-writing arrangements for some chapters, collective discussions of chapter drafts between authors from each section, and written feedback from peer contributors as well as the editors. The aim of this process was not to create consensus, but rather to eventually convey a lively debate where different voices express themselves with sufficient clarity to be mutually intelligible, and where arguments rooted in different sensibilities speak to each other, instead of ignoring each other. One salutary aspect of this process is that it sometimes led us to see and circumvent peculiarities of the conceptual jargons or assumptions shared conventionally within specific fields, hopefully to the benefit of a similarly diversified readership. 


\section{From spotlights to shadows: how the book is organized}

The cross-national orientation of the book, and the case examples it discusses, serve its overarching goal to look into both the local and global shadows of transitional justice. To inspect the local shadows, the book relies on some emblematic cases which include South Africa, but also Rwanda and Argentina, with a focus on processes and societal dynamics not yet mainstreamed in the abundant literature that exists already on these cases. To inspect the global shadows created by these same cases - which tend to set the standard of what is and what is not considered as a transitional justice process in the international arena - the book integrates contributions from experts of sites better known for resisting the setting-up of mechanisms to deal with their troubled pasts than for embracing international norms of transitional justice, such as Sri Lanka, Turkey and Côte d'Ivoire. To combine, moreover, the advantages of contextual depth and multiple perspectives on one specific case with the reward of cross-contextual variability and comparative analysis, the book features two key case analyses deepened through several contributions - South Africa, as a prototypical case of transitional justice, and Sri Lanka, as a case of "resistance", alongside analyses of multiple cases, within and across individual contributions.

In effect, the book is organized as a counter-current journey from the spotlight to what is in the shadow of transitional justice. Starting with a description of how instructive cases of transitional justice have turned commemoration into celebrations of a certain version of history, the different contributions then progressively explore the issues, actors and resources that are typically forgotten when societies celebrate their pasts rather than mourn their losses, or get sidelined in the focus on the classic pillars of transitional justice.

The first section of the book hence presents three cases where commemoration of past suffering has turned into political celebration of the moral triumph of overcoming past harm, and of the role of current regimes. The ensuing self-referential dynamics by which victors, or those "on the right side of history", celebrate their achievements tend to obscure the creative process of undoing frontlines, making emergent communities visible, transforming understandings of social relationships and empowering new collectives of actors. The first two case analyses, by Murithi and by Jessee, show how commemoration has turned into celebration in the aftermath of emblematic transitional justice processes in South Africa and Rwanda. The following contribution, by Saravanmuttu, shows how, in Sri Lanka, similar political ends are achieved, ironically, through resisting international pressures for transitional justice rather than by complying with them.

The second section pursues a systematic analysis of three types of challenges that justice delivered during limited periods of transition, and focusing on the most egregious forms of violence, struggles with tackling structural social inequality (Durrheim and Murray); being relevant to post-generations, born after specific violent events but affected by their long-term 
consequences (Surenthiraraj); and preventing new forms of violence grounded in the disenchantments of the formerly oppressed, when expectations for historical redress remain unfulfilled (Kerr and Dixon). Bringing into focus time periods long after the official dismantling of apartheid in South Africa, or the resettlement of Muslims evicted from their homes during the civil war in Sri Lanka, these chapters foreground what has been neglected in the mechanisms instituted and the fault lines that have emerged in the meantime.

The third section highlights those who are left out, or inadequately considered, when transitional justice is delivered as a nationalist and state-driven process in the hands of victors, or parties and institutions claiming the moral high ground. Discussing prosecutions and truth-processes from the perspective of exiles on the one hand (Parmentier, Rauschenbach and Hein), and women from rural communities on the other (de Mel and Medawatta), and state-sponsored "rehabilitation" from the perspective of former combatants, including child and female combatants (Usoof-Thowfeek and Gunasekera), the section offers insights into why a broader or fairer inclusion of forgotten actors is vital for avoiding some of transitional justice's pitfalls.

The fourth and final section starts with Jones' critical examination of resistance to transitional justice, problematizing the normative assumptions underlying its understanding and inviting us to see the creative potential in certain forms of resistance. The section then moves on with three systematic discussions, offered by Vollhardt, Twali and Jayakody, by Acar and Reicher, and by Penic, Drury and Bady, of under-exploited collective resources that can potentially make engagement with collective trauma more transformative, such as inclusive, cross-sides narratives, the creative power of crowds and new, emergent forms of solidarity and resilience.

Our guiding ambition in the process of assembling and bringing into dialogue these different contributions has been to end up with a collective book that becomes more interesting when it is explored as a whole. We hope that its readers might approach it like a collective exhibition, where one not only wishes to rush to one's favourite piece but takes the time to wander around and let oneself be surprised by how each piece gains an additional dimension through the context created by all the others.

\section{Acknowledgements}

The work leading to this chapter and book has been greatly facilitated by two research grants from the Swiss National Science Foundation, funding the Pluralistic Memories Project (r4d - Swiss Programme for Research on Global Issues for Development, SNSF grant numbers: 400240_146955 / 400240_171188). The University of Lausanne, through its International Relations Office, has provided financial and logistic support for the Lausanne Summer School on Transitional Justice and Conflict Transformation, without which many of the encounters at the origin of the book would not have taken place. The editors would also like to thank all members of the 
Pluralistic Memories Project for years of fruitful exchanges, which have inspired much of the ideas and research discussed in this book.

\section{References}

Balasco, Lauren Marie. "Locating transformative justice: Prism or schism in transitional justice?” International Journal of Transitional Justice, vol. 12, no. 2, 2018, pp. 368-378.

Ben-Josef Hirsch, Michal. "Ideational change and the emergence of the international norm of truth and reconciliation commissions". European Journal of International Relations, vol. 20, no. 3, 2014, pp. 810-833.

Billig, Michael. Banal nationalism. London, Sage, 1995.

Billig, Michael, and Cristina Marinho. The politics and rhetoric of commemoration: How the Portuguese parliament celebrates the 1974 revolution. London, Bloomsbury, 2017.

Brounéus, Karen. "The trauma of truth telling: Effects of witnessing in the Rwandan gacaca courts on psychological health". Journal of Conflict Resolution, vol. 54, no. 3, 2010, pp. 408-437.

Burnet, Jennie E. "The injustice of local justice: Truth, reconciliation, and revenge in Rwanda". Genocide Studies and Prevention, vol. 3, no. 2, 2008, pp. 173-193.

Buxton, Rebecca. "Reparative justice for climate refugees". Philosophy, vol. 94, no. 2, 2019, pp. 193-219.

Di Pasquale, Caterina. "Massacre, trial and 'choral memory' in Sant'Anna di Stazzema, Italy (1944-2005)”. International Journal of Transitional Justice, vol. 6, no. 3, 2012, pp. 486-501.

Dixon, John, and Kevin Durrheim. "Contact and the ecology of racial division: Some varieties of informal segregation". British Journal of Social Psychology, vol. 42, no. 1, 2003, pp. 1-23.

Dixon, John, Guy Elcheroth, Philippa Kerr, John Drury, Mai Albzour, Emina Subašić, Kevin Durrheim, and Eva G. T. Green. "It's not just 'us' versus 'them': Moving beyond binary perspectives on intergroup processes". European Review of Social Psychology, vol. 31, no. 1, 2020, pp. 40-75.

Drury, John. "Beyond the contagion concept". Psychology Review, November 2018.

Echterhoff, Gerald E., Tory Higgins, and John M. Levine. "Shared reality: Experiencing commonality with others' inner states about the world". Perspectives on Psychological Science, vol. 4, no. 5, 2009, pp. 496-521.

Elcheroth, Guy, and Stephen Reicher. Identity, violence and power: Mobilizing hatred, demobilizing dissent. London, Palgrave Macmillan, 2017.

European Commission. A Union of Equality: EU anti-racism action plan 2020-2025. European Commission, 18 September 2020, ec.europa.eu/info/sites/default/files/a_ union_of_equality_eu_action_plan_against_racism_2020_-2025_en.pdf. Accessed 29 March 2021.

Evans, Matthew. "Structural violence, socioeconomic rights, and transformative justice". Journal of Human Rights, vol. 15, no. 1, 2016, pp. 1-20.

Evans, Matthew. Transformative justice: Remedying human rights violations beyond transition. London, Routledge, 2018.

Gready, Paul. The era of transitional justice: The aftermath of the truth and reconciliation commission in South Africa and beyond. London, Routledge, 2011. 
Gready, Paul. "Introduction". From transitional to transformative justice, edited by Paul Gready and Simon Robins. Cambridge: Cambridge University Press, 2019, pp. 1-28.

Gready, Paul, and Simon Robins. From transitional to transformative justice. Cambridge University Press, 2019.

Höglund, Kristine, and Camilla Orjuela. "Friction and the pursuit of justice in postwar Sri Lanka”. Peacebuilding, vol. 1, no. 3, 2013, pp. 300-316.

Hyndman, Jennifer, and Amarnath Amarasingam. "Touring 'terrorism': Landscapes of memory in post-war Sri Lanka”. Geography Compass, vol. 8, no. 8, 2014, pp. 560-575.

Human Rights Council. Human Rights Council holds an urgent debate on current racially inspired human rights violations, systemic racism, police brutality and violence against peaceful protests. News section of the United Nations Human Rights Council, 17 June 2020, www.ohchr.org/EN/HRBodies/HRC/Pages/NewsDetail.asp x?NewsID=25971\&LangID=E. Accessed 29 March 2021.

Jessee, Erin. "The danger of a single story: Iconic stories in the aftermath of the 1994 Rwandan genocide". Memory Studies, vol. 10, no. 2, 2017, pp. 144-163.

Kerr, Philippa, Kevin Durrheim, and John Dixon. "Xenophobic violence and struggle discourse in South Africa". Journal of Asian and African Studies, vol. 54, no. 7, 2019, pp. 995-1011.

Khalili, Laleh. "Heroic and tragic pasts: Mnemonic narratives in the Palestinian refugee camps 1". Critical Sociology, vol. 33, no. 4, 2007, pp. 731-759.

Klar, Yechiel, Noa Schori-Eyal, and Yonat Klar. "The 'never again' state of Israel: The emergence of the Holocaust as a core feature of Israeli identity and its four incongruent voices". Journal of Social Issues, vol. 69, no. 1, 2013, pp. 125-143.

Klinsky, Sonja, and Jasmina Brankovic. The global climate regime and transitional justice. London, Routledge, 2018.

Kochanski, Adam. "The 'local turn' in transitional justice: Curb the enthusiasm". International Studies Review, vol. 22, no. 1, 2020, pp. 26-50.

Licata, Laurent, and Olivier Klein. "Holocaust or benevolent paternalism? Intergenerational comparisons on collective memories and emotions about Belgium's colonial past". International Journal of Conflict and Violence, vol. 4, no. 1, 2010, pp. $45-57$.

Macherey, Pierre. A theory of literary production. London, Routledge \& Kegan Paul, 1978.

Marsh, Elizabeth J. "Retelling is not the same as recalling: Implications for memory". Current Directions in Psychological Science, vol. 16, no. 1, 2007, pp. 16-20.

McKnight, Janet. "The anatomy of mass accountability: Confronting ideology and legitimacy in Rwanda's gacaca courts”. Conflict Trends, vol. 1, 2014, pp. 35-42.

Millar, Laura. "Touchstones: Considering the relationship between memory and archives". Archivaria, vol. 61, 2006, pp. 105-126.

Nyborg, Karine, et al. "Social norms as solutions." Science, vol. 354, no. 6308, 2016, pp. $42-43$.

Orjuela, Camilla. "Passing on the torch of memory: Transitional justice and the transfer of diaspora identity across generations". International Journal of Transitional Justice, vol. 14, no. 2, 2020, pp. 360-380.

Parasram, Ajay. "Erasing Tamil Eelam: De/re territorialisation in the global war on terror". Geopolitics, vol. 17, no. 4, 2012, pp. 903-925.

Pasupathi, Monisha, Kate C. McLean, and Trisha Weeks. "To tell or not to tell: Disclosure and the narrative self”. Journal of Personality, vol. 77, no. 1, 2009, pp. 89-124. 
Pasupathi, Monisha, Lisa M. Stallworth, and Kyle Murdoch. "How what we tell becomes what we know: Listener effects on speakers' long-term memory for events". Discourse Processes, vol. 26, no. 1, 1998, pp. 1-25.

Ponselet, Gaëlle. "Commission on Belgium's colonial past: 'It's important, but will it succeed?" Justice Info, 8 October 2020, www.justiceinfo.net/en/45612-commissionbelgium-colonial-past-important-but-will-it-succeed.html. Accessed 29 March 2021.

Ramanathapillai, Rajmohan. "Past traumas and present suffering: Consequences of Buddhist narratives in the Sri Lankan peace process". South Asia: Journal of South Asian Studies, vol. 35, no. 4, 2012, pp. 832-857.

Ramanathapillai, Rajmohan. "The politicizing of trauma: A case study of Sri Lanka". Peace and Conflict, vol. 12, no. 1, 2006, pp. 1-18.

Rimé, Bernard, et al. "The impact of Gacaca tribunals in Rwanda: Psychosocial effects of participation in a truth and reconciliation process after a genocide". European Journal of Social Psychology, vol. 41, no. 6, 2011, pp. 695-706.

Spini, Dario, Davide Morselli, and Guy Elcheroth. "War experiences and emerging rights claims in postwar former Yugoslavia: The role of generalized conflict exposure and collective anomie.” European Journal of Social Psychology, vol. 49, no. 6, 2019, pp. 1173-1189.

Thiranagama, Sharika. "Claiming the state: Postwar reconciliation in Sri Lanka". Humanity: An International Journal of Human Rights, Humanitarianism, and Development, vol. 4, no. 1, 2013, pp. 93-116. 


\section{Part I}

Commemoration as celebration 



\title{
2 Celebrating the end of apartheid
}

\author{
Tim Murithi
}

\section{Introduction}

In the mid-1990s, transitional justice originated from a legalistic tradition, with a narrow emphasis on the use of judicial processes to address civil and political violations in countries undergoing transition (Murithi 2009). Africa's experience demonstrated that traditional notions of transitional justice needed to be rethought and reframed. African actors derived these lessons from their own cultural practices as well as from elsewhere around the world and contributed towards diffusing them. Specifically, in order to effectively address the real concerns of victims of past violations, transitional justice norms had to be expanded beyond their civil and political focus to include socio-economic and psychosocial dimensions and to engage memorialization and commemoration.

One of the central dilemmas of transitional justice, namely the tension between the pursuit of accountability and the inclusive memorialization and commemoration of past violations, continues to play itself out in the majority of post-conflict situations in Africa. Specifically, South Africa, Rwanda, Uganda, Kenya, Sierra Leone and Liberia adopted processes and institutions which sought to address the violations of the past, but did not leverage the opportunity provided to deepen the processes of commemoration. Rather, the South African, Kenyan and Sierra Leonean Truth and Reconciliation Commissions (TRCs) touched upon the importance of memorialization and commemorative processes, and some of their experiences have been analysed, modified and adopted by other states around the world.

The South African TRC was established in the context of a transition impacted by violence and the targeted, politically motivated killing of over 5,000 people (eNCA 2014). In the aftermath of the transition, the opposing military forces were entirely capable of unleashing more mayhem on the citizens of the country. On the one hand, there were heightened fears of retribution among the so-called white, previously advantaged communities. On the other hand, demands emerged for a punitive form of redress for apartheid atrocities among sections of the previously disadvantaged people of colour. Consequently, the South African TRC was conceived as a

DOI: $10.4324 / 9781003167280-3$ 


\section{Tim Murithi}

palatable "middle way" between outright retribution and blanket impunity. There had been very few previous experiments with the use of truth commissions, based mainly in Latin America and the Balkans, and in which the importance of quelling the flames of political violence and retribution was taking priority over correcting the economic crimes of apartheid. According to Charles Villa-Vicencio - who had been Research Director of the TRC and then Executive Director of the succeeding Institute for Justice and Reconciliation (IJR) - the TRC was assigned "the important task of instituting corrective moral justice by putting the record straight ... it had no power to execute punitive justice, nor did it have the power to execute distributive justice, in the sense of correcting material imbalances" (Villa-Vicencio 2004, p. 20, emphasis added).

Focusing on the South African experience, in this chapter I will explore how transitional justice processes can raise awareness, and mobilize societal and political engagement with the lasting legacies of historical experiences, by providing a narrative of the past that is "complete enough". In my view, this presupposes, first of all, an effort to identify the lasting effects of material imbalances, which can then provide the basis for more pluralistic and inclusive forms of commemoration.

\section{Apartheid and memory}

South Africa's history is a story of entitlement and preference for one group at the expense of another. The way that the ensuing historical injustice is remembered reflects the extent to which South Africa's citizenry is transitioning towards a fairer and more inclusive society (Alexander 2002). In 1652, the Dutch settler community, led by Jan van Reeibeck, gradually begun to define what belonged to them and what they were entitled to. Perversely, this process also defined what the natives and indigenous people were not entitled to. In 1913, the Native Land Act solidified European settler privilege, and further disenfranchised the coloured and black population (Alexander 2002). This act eschewed the moral responsibility of the European settlers to their fellow human beings, and through such legal instruments a culture of entitlement became entrenched further in the country. Simultaneously, socalled coloured and black people, which are problematic terms to use, became dispossessed of their land and rights to their land. They became disowned by the nation that was supposed to provide them with the means to self-sovereignty and the means to flourish as human beings.

The South African apartheid project, which was formally implemented between 1948 and 1994, was one of the most extensive projects of racial entitlement and disenfranchisement in recent human history (Wilkins and Strydom 2012). It was a vast and comprehensive "white" cultural, political, social and economic empowerment programme which generated and perpetuated wealth for the white minority population. Its logical consequences were poverty, deprivation and destitution for a large majority of black and 
coloured people (Van Der Westhuizen 2007). Apartheid, at its core, was also a patriarchal project: it promoted gender subservience, an elitist philosophy and the subjugation of some human beings for the benefit of others. It established an aggressive misuse of power for the purpose of materialistic gain and thereby created an alienated sense of nationhood, particularly among the oppressed. In effect, it was a system of exploitation and systemic oppression which also perpetuated great harm to the psychology of its victims and survivors (Bunting 1969).

The extensive apartheid laws imposed on South Africa during this period were designed to brainwash the population and insinuate a racial prism in their psyches. Apartheid was at its heart a totalitarian system: a programme designed to alter the minds and souls of human beings and orient them towards separation and segregation in deeply fundamental ways (Bunting 1969). If we want to transcend, through processes of commemoration and memorialization, the psychic orientation created by this brainwashing programme, it is essential to grasp the full extent to which it has altered people's understandings of social reality.

The reason why the apartheid "reality construct" remains so powerful in memory, and in the lived reality of many South Africans today, is because it was insidiously effective in moulding people's minds through political, economic and social engineering (Bunting 1969). In effect, apartheid was one of the most devious mind-altering systems ever devised by a group of human beings to subjugate, subordinate, marginalize and exclude another group of people. It is important to understand, however, that the legacy of the reality of apartheid produces effects that shape different people's memories in different ways. The sense of injustice of the system does not permeate the memories of the beneficiaries of apartheid and their descendants as strongly as it does those of the survivors and their descendants (Institute for Justice and Reconciliation 2019).

During apartheid, South Africa was a divided nation. The answer to the question of who constitutes the nation was quite clear to the authors and beneficiaries of apartheid. At the core of their brutal psychic experiment was race socialization (Fatton 1986). So-called white people were systematically taught how to be, act and interact with their fellow human beings as racists (Helms 1990; Thompson and Carter 1997). The eminent Martinican theorist of race Frantz Fanon has argued in his seminal book Black Skin, White Masks that the objective of race socialization is to programme a sense of superiority and self-pride among "white" people and to inflate their sense of self-worth (Fanon 1967). The opposite side of the coin was a systematic programme to malign the so-called black people by casting them as subhuman, primitive, lazy, promiscuous, untrustworthy, violent and crime-prone (Thompson and Carter 1997). This apartheid construct sought to impose black inferiority as an acceptable worldview and the segregation of black people in dilapidated townships and shanty towns - with all the social ills that this generated including, ironically, criminality - as an acceptable policy. 


\section{Tim Murithi}

This system hence instituted a lack of self-worth among black people and strictly constrained their opportunities for self-expression, creativity and, in particular, for commemoration and memorialization.

The apartheid system established race identities based on the perception that people share a common heritage with a particular racial group, such as so-called whites, and not with others, such as so-called blacks (Frederickson 1988). These sentiments are still widespread and very much alive in today's South Africa. For example, the Institute for Justice and Reconciliation's South African Reconciliation Barometer (SARB) shows that, while there has been some degree of racial integration, there is still a long way to go for the country's citizens to genuinely interact with each other as cultural equals. Specifically, the SARB data show that "most South Africans report that they would like to interact more often with people from other race groups, but for many people language and confidence barriers, as well as negative prior experiences, represent obstacles to doing so" (Institute for Justice and Reconciliation 2019, p. 8, emphasis added). Findings such as these suggest that the racial prism instilled by apartheid into all who lived with the system, whether as beneficiaries or survivors, continues to have lasting, transgenerational effects.

\section{The transformative function of transitional justice}

Transitional justice can be delivered through a wide range of mechanisms, which seek to frame and catalyse the different processes by which societies affected by violent conflict or authoritarian rule address past violations, as a precursor to laying the foundations for more inclusive societies (Murithi 2009). From its predominantly legalistic origins, transitional justice has confronted a range of societal, economic and political pressures that have precipitated a broader scope and mandate. Many of these pressures emerged from processes that were unfolding on the African continent, which placed the continent at the forefront of experimentations with pushing the boundaries of transitional justice (Murithi 2016).

The prosecutorial framework implemented in Latin America and the Balkans in the mid-1990s was soon confronted by a proliferation of cultural, social, economic and political contradictions, which challenged the narrow focus of legally inspired transitional justice norms (Murithi 2016). In cases where historic violations went unpunished, unrecognized or not memorialized, a sense of injustice and moral contradiction can prevail for long afterwards (Buckley-Zistel et al. 2014). The legal approach to transitional justice is also generally unable to provide effective redress for systematic societal injustice or economic crimes, because the causal relations involved can hardly be established in terms of specific acts perpetrated against specific victims. In situations in which a particular ethnic or racial group has benefited from the economic exploitation of another, responsibility is often widespread and diffuse, from the political leaders who implemented the policies to 
the constituencies that supported or voted for them. In most cases, it is challenging to pinpoint individual perpetrators for the prosecution of economic crimes. The processes needed to promote redress typically include, therefore, a range of interventions located beyond the scope of a punitive model of transitional justice. Transitional justice rapidly had to face a broad range of challenges and a multiplicity of expectations: to administer justice; to restore societal trust; to facilitate commemoration and memorialization of past violations; and/or to promote reconciliation in deeply divided communities. In particular, the demands for socio-economic justice have pushed the normative boundaries of transitional justice beyond the confines of its historical origins within the legal sphere.

\section{South Africa's Truth and Reconciliation Commission}

In spite of the available option of pursuing prosecutions for the human rights violations that were committed during apartheid, South Africa deliberately chose the path of prioritizing a restorative transitional justice model (Du Toit and Doxtader 2011). The option of prosecution was available during the country's transition, in the mid to late-1990s, and is still viable even to this day. The fact that South Africa adopted its own unique path still distinguishes it as a norm-setter, and the model it adopted is constantly being analysed and scrutinized around the world for its important insights. Following Ben-Josef Hirsch (2006), the South African TRC has critically contributed to an international norm-setting process in terms of the global popularization of truth commissions and the trans-nationalization of its guiding principles (Ben-Josef Hirsch 2006). The South African model has been attractive to a broad range of national and international actors, due to its widely perceived success in enabling South African society to move forward from a divisive and brutalizing past, avoiding a full-blown descent into internecine armed conflict. However, it is evident that, despite the path it chose, the country has not yet addressed all the challenges emanating from its past. Apartheid-generated racism, gender-based violence, inequality and poverty remain endemic in South African society. In effect, there is latent violence within South African society which, like the apparently dying embers of a glowing fire, can rapidly flare up again and undermine social stability. This fact seems to be routinely glossed over by many international observers, which continues to imbue the South African TRC with a false aura of efficacy (Waldmeir 1998). Consequently, because it has frequently been portrayed as the quintessential truth and reconciliation commission, the widely disseminated South African model has had a major impact on the establishment of public truth-telling as a critical component of transitional justice in the global arena.

The South African TRC was empowered with adequate authority and legitimacy to discuss the socio-economic basis of apartheid, and to suggest possible reform programmes (Selim and Murithi 2011). However, the TRC adopted specific definitions of key terms like "violations", "abuses" and "participation" 


\section{Tim Murithi}

that significantly narrowed its mandate, and consequently limited its ability to engage with, and provide guidance on, the ideological and socio-economic aspects of apartheid (Barchiesi 1999, p. 8). Advocates of the approach adopted by the TRC have argued that if the TRC had attempted to provide a historical reconstruction of the "truth" which included socio-economic oppression under apartheid, and elaborate on decisive recommendations for systemic economic and social restructuring, then the Commission would have faced formidable political obstacles. According to Barchiesi (p. 8), "any attempt by the TRC to challenge those obstacles would have probably entered a contradiction with the functional purpose to promote national unity and reconciliation". However, critics have responded that millions in South Africa did not identify with the TRC initiatives under the chosen terms, or did so to a limited extent only and instead turned their hopes towards education, employment, healthcare or economic growth (Colvin 2008, p. 418).

\section{Shifting paradigms and the enduring impact of the TRC}

Over time, growing historic distance and shifting theoretical paradigms have reopened the debate on the enduring societal impact of the TRC (Bell and Ntsebeza 2003). Specifically, the inability of South African society to achieve a much more profound transformation has raised questions about the effectiveness of a reconciliation agenda that is not sufficiently buttressed by an equivalent programme of socio-economic redress. In particular, a younger generation of South Africans, who were born after the 1994 transition to independence and democratic governance, have questioned the legal and socio-economic utility of the TRC. Concretely, progressive and humanistoriented youth formations have argued that while the political functionality of the TRC was evident, the inability of the Commission to lay the foundations for bringing about a fundamental transformation in the material lives of the majority of people in South Africa has undermined its moral effectiveness. In addition, they have questioned the moral probity of a national institution that seemed to have placed the burden of "reconciliation" on the victims and survivors of the brutal apartheid system of white supremacy and human exploitation (Crush 2008). Njamnjoh, in his seminal book \#RhodesMustFall: Nibbling at Resilient Colonialism in South Africa (2016), and other critics of the South African transition, have further argued that the failure of the wider "white" sector of the South African society to embrace the TRC as a collective platform for memoralization and commemoration of the injustices of the past - as a tool to promote deeper cultural and societal transformation of racial attitudes and economic wealth - implies that it was a missed opportunity for the country as a whole.

For the South African project going forward, it has to pick up from where the TRC left off and to pursue the challenging pathway of deeper introspection as well as the unlearning of white supremacists' attitudes, which regrettably are all too common and are regularly reported upon across the society as a whole 
(Njamnjoh 2016; Reddy 2015). This will require revisiting the objectives of the TRC with a view to creating new spaces for more pluralistic forms of memorialization and commemoration, which challenge the perceived and persistent orthodox viewpoint of the South African "miracle" or the "rainbow nation". This will be a challenging but necessary journey for South Africa to undertake in order to mitigate against the further fragmentation and the resurgence of apartheid patterns of thought and behaviour, which are increasingly becoming evident across the country. As Kerr and Dixon (Chapter 7) as well as Durrheim and Murray (Chapter 5) in this volume observe, these include the phenomenon of xenophobia, witnessed in 2008, 2015 and 2019, which included the targeted killing by South Africans of African citizens who had immigrated from other parts of the continent, particularly in the high-density low-income urban informal settlements. In effect, this is a side effect of the increasing fragmentation of the society, fuelled by unresolved and residual identity politics and by patterns of economics distribution inherited from the apartheid system of segregation and exploitation (Crush 2008). The Institute for Justice and Reconciliation's SARB notes that "xenophobic sentiments are pervasive with roughly four in ten $(40 \%)$ of South Africans agreeing that they are likely to prevent people from other African countries from accessing certain services and from participating in certain activities" (IJR 2019, p. 8).

The South African TRC was established during a "honeymoon" period, when the celebration of the end of apartheid overshadowed reflections which could have created the space for a deeper form of engagement with the historical injustices that were meted out to the majority of the country's people. The South African TRC was therefore symptomatic of the "celebrative moment" that accompanies countries undergoing transition from conflict and authoritarianism towards democratic inclusivity and the rule of law. Consequently, the majority of South African society - and in particular affected families - were not able to utilize the national platform to give a broader range of meanings to past losses experienced during the brutal era of apartheid. A quarter of a century later, individuals and families are still attempting to take the initial step towards expressing more profound and meaningful forms of commemoration for the historical injustices that they endured. Regrettably, these processes have now been left to survivors to drive through on their own initiative, as successive post-apartheid governments have become absorbed in addressing basic socio-economic challenges.

\section{Revisiting the TRC's limited engagement with the past}

South Africa's TRC sought to trigger social change in the country by illuminating a certain version of its past and promoting the envisaged future of an idealized "rainbow nation". In effect, the TRC did establish a dedicated institution to oversee the implementation of its recommendations, but subsequent African National Congress (ANC) governments only paid lip service to the recommendations of the TRC. This was in part because they disagreed 


\section{Tim Murithi}

with the TRC's approach of attempting to establish a moral equivalency between some actions of the anti-apartheid liberation struggle and the deeds of the apartheid system of police, military and intelligence. Ultimately, the oversight in establishing more wholehearted TRC implementation mechanisms has undermined efforts to leverage the achievements of the Commission to advance societal dynamics that could reconfigure South African society and transform it more deeply.

What did South Africa leave out when it convened the TRC to remember its past? Some critics have argued that instead of being a framework for truth recovery, the South African TRC was in fact the place where the truth went to die (Molefe 2014). The fact that only 21,000 statements were collected by the Commission, in a country of 43 million people at the time, implies that numerous atrocities and human rights violations still remained undocumented. Consequently, the documented narratives contained in the TRC reports represent an incomplete historical record of the wide-ranging experiences of South Africans across the country. While there are multiple factors why more people could not participate in the TRC process, it is clear that there is still a need for ongoing engagement with the past, on a nation-wide scale. There have been a number of state-led commemorative processes, including the construction of key memorials across the country, such as the Freedom Park in Pretoria, the Apartheid Museum in Johannesburg and the Hector Petersen Museum in Soweto, to name but a few. In addition, there has been a concerted effort by national and provincial governments to rename places and streets in order to commemorate the injustices of the past and, to a certain extent, contribute to the pluralization of memory. However, there are issues and societal dynamics that the TRC was unable to address, despite its efforts to memorialize the violations of apartheid.

\section{Rhodes Must Fall as a commemorative movement}

The TRC did not rise to the challenge of dismantling the structural violence of racist ideology and racial attitudes that were indoctrinated into the socalled white population of South Africa. The Rhodes Must Fall (RMF) movement unleashed societal dynamics that, once more, brought to the fore the failure of previous attempts to address the white supremacist ideology that was, and still is, all pervasive in South African society. The RMF movement emerged as an organic movement led by a horizontal structure of student collectives. Ultimately, it spread to other universities across South Africa, and even inspired a similar campaign at Oxford University's Oriel College which was a beneficiary of Cecil Rhodes' financial contributions and which displayed his statue prominently at its entrance.

The RMF as a commemorative movement directly challenged the "silences" and continuing marginalization of the majority of the country's population, which were all too evident more than two decades after the celebratory end of apartheid. The RMF movement advocated for a different 
form of commemoration: one that is rooted in the celebration and appreciation of the "Africanness" instead of the "Europeanness" implied by the colonial and apartheid-informed logic that continues to persist. The most evident form of the attempt to create space for new representations of the past was the concerted campaign, launched on 9 March 2015 by the RMF movement, to bring down the statue of Cecil Rhodes from its prominent location at the Upper Campus of the University of Cape Town. The statue depicted Rhodes sitting and surveying his vast empire which he had accumulated by implementing a policy of white supremacy and predatory exploitation of South Africa's people, land and resources. As noted in Maylam's book entitled The Cult of Rhodes: Remembering an Imperialist in Africa, these policies served to establish a colonial system of rule, his own private accumulation of wealth and stated ambition to dominate Africa from the Cape to Cairo (Maylam 2005). On 9 April 2015, the RMF student movement succeeded in achieving this objective and the Rhodes statue "fell" leading to subsequent calls for replacing it with a statue of a prominent and distinguished African (Njamnjoh 2016).

The RMF movement was not only committed to removing the statue and calling for alternative forms of commemoration, including the renaming of university buildings after prominent Africans, but was also driven by a stated agenda to "decolonize" education across the whole of South Africa (Njamnjoh 2016). The South African TRC had been unable to confront and foreground the issue of the decolonization of education, as well as of other sectors, which consequently remained silenced or overshadowed by the selective performance of transitional justice that was enacted during and after the work of the Commission. The RMF movement is now setting in motion these previously overlooked dynamics of introspection and of confrontation of internalized Eurocentric norms across South Africa, the government bureaucracy, the judicial system and the private sector.

This project of decolonizing South African society echoes historical initiatives across the continent and is reinforced by the appeal in the African Union Transitional Justice Policy "to come to terms with the traumas of slavery, colonialism, apartheid, systematic repression and civil wars" (African Union 2019, p. 1). In advancing its campaign, the RMF movement directly challenges the silences that still prevail in relation to the "traumas of slavery, colonialism, and apartheid" while appealing to the wider South African society to embrace a more complete memory of the brutal history that the majority of the people of colour across the country endured. The commemorative act of bringing down the Rhodes statue at the University of Cape Town was, at its core, a statement alerting society to the urgency of questioning the historic creation of racial inequality, by targeting one of its most ardent proponents in the form of Cecil Rhodes. This was a necessary act because, among a significant portion of the so-called white population of South Africa, the attitudes and machinations of colonial entrepreneurs like Rhodes are not problematic (Cilliers 2008). For some members of this section 


\section{Tim Murithi}

of society, there is no need to dwell on the past. The South African author Charles Cilliers, in a chapter on "White Denial" in his insightful book For Whites Only, notes that, according to his own father, "apartheid is dead and buried - it does not matter any more" (p. 13). Cilliers argues that the views held by his father and other whites who identify with this position are the reason why it is necessary to commemorate the historic construction of racial inequality. In effect, without an attitudinal change in these mindsets, it will be more challenging to make the case for policies and legislations that would create fairer distribution of economic goods and reparation in favour of the descendants of those who were oppressed under apartheid.

\section{Economic commemoration as an act of memorialization}

The South African TRC did not address the structural economic crimes that were at the heart of the apartheid project. As Van Vuuren notes,

the relative invisibility of economic crimes and violations that resulted from the South African Truth and Reconciliation Commission (TRC) focus on torture and physical violence is something that continues to compromise those seeking economic and social justice in South Africa's ongoing transition.

(2017, p. 506)

The era of colonial conquest, which was closely accompanied by slavery, and then apartheid, was fuelled by a meta-narrative of racial superiority, but it was at its heart a project of economic subjugation and of the conversion of people of colour into units of production. How can such economic crimes and predatory exploitation be commemorated in the aftermath of a transition that seeks to right the wrongs of the past (Mamdani 1996)? In South Africa, there has been a tendency to consign this question to the realm of politics and economics, rather than to engage with it in the field of memorialization. However, memories of the historic economic exploitation of people of colour persists on a daily basis in the minds of their descendants, in South Africa as well as across the wider continent and in other parts of the world. The seminal book These Are the Things that Sit with Us (GobodoMadikizela et al. 2019), for example, shows that the memory of economic subjugation and exploitation looms large and can be a recurring source of trauma to subsequent generations of people of colour, whose forebears suffered under the yoke of apartheid and slavery. The lived reality of previous generations has been passed down through an oral tradition. Some of these stories have been documented and now exist as an historical societal record. Van Vuuren suggests that in South Africa "the memory of iniquity, injustice and oppression could not be erased as easily. It remains with those who carry that burden, physically, emotionally and materially" (2017, p. 2). This points to the need of "economic commemoration". 
Economic commemoration can be described as a process of memorialization conducted with the specific aim of promoting redress for the effects of economic exploitation, in particular to benefit subsequent generations of descendants of the criminally dispossessed. Historical economic exploitation, so long as it remains unaddressed, prevents the transmission of generational wealth to the descendants of the destitute as a means of improving their future livelihoods. The lingering memory of economic exploitation also complicates the overall processing of trauma. Consequently, in South Africa it is necessary to initiate processes of economic commemoration to contribute towards healing the memories of economic exploitation, as well as transforming the material livelihoods of the subsequent generations of the descendants of victims and survivors of apartheid.

In terms of the practical modalities of implementing economic commemoration, it is evident that symbolic actions will not be sufficient. Rather, economic redress and commemorative processes should be linked as means towards the improvement of people's livelihoods and well-being. Only by ensuring that there is a material improvement in the circumstances of descendants of survivors, as a form of reparation, can the journey towards the healing of memories begin. Practically, economic reparation can be implemented by ensuring that land that was forcefully dispossessed is restored to survivors and their descendants, as well as by ensuring that survivors and their descendants have fair access to hospitals, schools, university programmes and employment opportunities, in order to improve their livelihoods and lay the foundation for subsequent generations.

In South Africa, various government policies have sought to redress economic injustices of the past, such as wider access to education and social grants for millions of South Africans. However, the notion of economic commemoration has not been explicitly mainstreamed so far. Therefore, there is scope going forward to rearticulate the processes of economic redress in South Africa with acts of memorialization and commemoration for the historical exploitation of people of colour. As Hennie Van Vuuren notes in his seminal book, Apartheid Guns and Money:

[W]e do not need to consider South Africa's transition as ending with the report of the TRC ... the identification and return of money stolen through [economic] crimes could contribute towards a broader and further-reaching reparations programme. New hearings and community meetings could help to develop a better understanding of how individuals and communities suffered as a result of economic crimes and structural violence.

(2017, p. 507, emphasis added)

Furthermore, Van Vuuren (2017, p. 510) argues that the "abuse of power cannot be treated as an uncomfortable fact to be dealt with by future generations. It deserves our attention right now ... and ... we must ... seek to 


\section{Tim Murithi}

hold those who profited from injustice to account". In effect, it is necessary to challenge the current orthodoxy of transitional justice mechanisms, and to advance processes to remedy the lingering and lasting effects of economic crimes, which continue to afflict the survivors of apartheid and their descendants.

\section{The transformative potential of commemoration}

The South African TRC has become an example of pursuing a moral compromise, namely dealing with the legacy of the apartheid regime, but without triggering a profound transformation of racial inequality. Ultimately, the Commission will be assessed on the basis "not of who went to jail but whether the quality of life is better" (Seider, cited in Mani 2002, p. 125). Transitional justice processes, and truth recovery commissions in particular, have the potential to provide a context for the memorialization of a broader range of issues relating to the livelihoods and well-being of survivors and their descendants, such as racial equality, land restoration, health and education provisions. But when truth commissions prove incapable of engaging with deeper root causes, this can render the process of transitional justice symbolic and limit its remedial utility (Selim and Murithi 2011; Arbour 2007; Leebaw 2005). As Gready and Simons (2019) argue, transitional justice needs to aspire to be more transformative in its impact and to engage more widely with the local agency of affected communities. Through a broadening of the notion of commemoration, it becomes conceivable to transform the nature of transitional justice interventions and to embrace a wider range of memorial practices. Concretely, transitional justice processes and actors need to liaise with the health and education sectors as necessary sites of commemoration, in order to provide a deeper and more inclusive form of redress for the harm done in the past.

\section{Conclusion}

South Africa's response to its legacy of human rights violations and crimes against humanity have influenced the evolving norms of transitional justice around the world. The implementation of the South African TRC was an extension of the "celebratory moment" brought about by the end of apartheid. However, the orthodoxy that the TRC pursued meant that key issues were overshadowed and relegated to the margins: notably a more inclusive approach to memorialization, in terms of the nature of the crimes to be commemorated. This chapter assessed the South African TRC's efforts to recover the truth of past injustices and to provide a platform for engaging with processes of redress and memorialization. The TRC cannot be expected to have solved the complex social, economic and political problems that South Africa faced, but it could have endeavoured to provide a more complete narrative and to promote fairer commemoration of past traumas. In 
that sense, it might have missed a historic opportunity to raise awareness and mobilize societal and political engagement with a broader range of lasting legacies of the apartheid system and, notably, to pave the way for a programme to commemorate economic crimes as well as to provide concrete reparations to the many victims of apartheid and their descendants.

\section{References}

African Union. Transitional justice policy. African Union policy documents, 25 April 2019, https://au.int/sites/default/files/documents/36541-doc-au_tj_policy_eng_web. pdf. Accessed 1 March 2020.

Alexander, Neville. An ordinary country: Issues in the transition from apartheid to democracy in South Africa. Pietermaritzburg, University of Natal Press, 2002.

Arbour, Louise. "Economic and social justice for societies in transition". New York University Journal of International Law and Politics, vol. 40, no. 1, 2007, pp. 1-28.

Barchiesi, Franco. Socio-economic exploitation, meaning contestation and the TRC: Problematic foundations for a discourse of social citizenship in post-apartheid South Africa, 1999, http://works.bepress.com/cgi/viewcontent.cgi?article=1015\&context= franco_barchiesi. Accessed 1 March 2020.

Bell, Terry, and Dumisa Ntsebesa, editors. Unfinished business: South Africa, apartheid and truth. London, Verso Books, 2003.

Ben-Josef Hirsch, Michal. "Agents of truth and justice: Truth commissions and the transitional justice epistemic community", Rethinking Ethical Foreign Policy: Pitfalls, Possibilities and Paradoxes, edited by David Chandler and Volker Heins. London, Routledge, 2006, pp. 184-205.

Biko, Steven. I write what I like: Selected writings. Johannesburg, Picador, 2005.

Buckley-Zistel, Susanne, Teresa Coloma-Beck, Christian Braun, and Friedrike Meith. Transitional justice theories. London, Routledge, 2014.

Bunting, Brian. The rise of the South African reich. London, Penguin, 1969.

Cilliers, Charles. For whites only. Johannesburg, X-Concepts Publications, 2008.

Colvin, Christopher. "Purity and planning: Shared logics of transitional justice and development". The International Journal of Transitional Justice, vol. 2, 2008, pp. 412-425.

Crush, Jonathan. The perfect storm: The realities of xenophobia in contemporary South Africa. Cape Town, IDASA, 2008.

Du Bois, Francois, and Antje Du Bois-Pedain, editors. Justice and reconciliation in post-apartheid South Africa. Cambridge, Cambridge University Press, 2008.

Du Toit, Fanie, and Eric Doxtader. In the balance: South African debate reconciliation. Johannesburg, Jacana Media, 2011.

eNCA. 1994 Bloody Miracle, 25 April 2014, http://bit.ly/eNCAnews. Accessed 20 January 2021.

Fanon, Frantz. Black skin, white masks. New York, Grove Press, 1967.

Fatton, RobertJr. Black consciousness in South Africa: the dialectic of ideological resistance to white supremacy. New York, SUNY Press, 1986.

Frederickson, George. The arrogance of race: Historical perspectives on slavery, racism and social inequality. Middletown, CT, Wesleyan University Press, 1988.

Friedman, Steven, and Doreen Atkinson. The small miracle: South Africa's negotiated settlement. Johannesburg, Ravan Press. 1994. 


\section{Tim Murithi}

Gobodo-Madikizela, Pumla, Friederike Bubenzer, and Marietjie Oelofsen. These are the things that sit with us. Johannesburg, Jacana Media, 2019.

Gready, Paul, and Simon Robins. From transitional to transformative justice. Cambridge, Cambridge University Press, 2019.

Helms, Janet. Black and white racial identity: Theory, research and practice. Westport, CT, Greenwood Press, 1990.

Institute for Justice and Reconciliation. SA reconciliation barometer survey. Cape Town, Institute for Justice and Reconciliation, 2019.

Leebaw, Bronwyn. Transitional justice, conflict, and democratic change: International interventions and domestic reconciliation, 2005, www.apsanet.org/imgtest/TaskFor ceDiffIneqLebaw.pdf. Accessed 1 March 2020.

Mamdani, Mahmoud. Citizen and subject: Contemporary Africa and the legacy of late colonialism. London, James Currey, 1996.

Mani, Rama. Beyond retribution: Seeking justice in the shadows of war. Cambridge, Polity Press, 2002.

Maylam, Paul. The cult of Rhodes: Remembering an imperialist in Africa. Cape Town, David Philip, 2005.

Molefe, Osiame. "Don't free South Africa's apartheid assassins", New York Times. 25 July 2014.

Murithi, Tim. The ethics of peacebuilding. Edinburgh, Edinburgh University Press, 2009.

Murithi, Tim, editor. The politics of transitional justice in the Great Lakes region of Africa. Johannesburg, Jacana Media, 2016.

Njamnjoh, Francis. \#RhodesMustFall: Nibbling at a resilient colonialism in South Africa. Bamenda, Langaa RPCIG, 2016.

Reddy, Thiven. South Africa, Settler Colonialism and the Failures of Liberal Democracy. London, Bloomsbury, 2015.

Seider, Roger. "Burying the past: Justice, Forgiveness and reconciliation in the politics of South Africa, Guatemala, East Germany, and Northern Ireland". Beyond retribution: Seeking justice in the shadows of war, edited by Rama Mani. Cambridge, Polity Press, 2002.

Selim, Yelim, and Tim Murithi. "Transitional justice and development: Partners for sustainable peace in Africa?".Journal of Peacebuilding and Development, vol. 6, no. 2, 2011, pp. 58-72.

Thompson, Chalmer, and Robert Carter. Racial identity theory: Applications of individual, group and organizational interventions. London, Lawrence Erlbaum Associates, 1997.

Van Der Westhuizen, Christi. White power and the rise and fall of the National Party. Cape Town, Zebra Press, 2007.

Van Vuuren, Hennie. Apartheid guns and money. Johannesburg, Jacana Media, 2017.

Villa-Vicencio, Charles. The art of reconciliation. Cape Town, Institute for Justice and Reconciliation, 2004.

Waldmeir, Patti. Anatomy of a miracle: The end of apartheid and the birth of a New South Africa. New Brunswick, NJ, Rutgers University Press, 1998.

Wilkins, Ivor, and Hans Strydom. The super-Afrikaners: Inside the Afrikaner Broederbond. Johannesburg and Cape Town, Jonathan Ball Publishers, 2012. 


\title{
3 Commemorating genocide in Rwanda
}

\author{
Erin Jessee
}

\section{Introduction}

Today, we pause to reflect on the tragedy we experienced and what we lost, both individually and as a nation. We will continue to educate new generations of Rwandans about what happened to our country, and what we learned from it.

We are putting those lessons into practice for the benefit of those who come after us. The lessons of our history have united us. They teach us the value of good leadership that cares for the well-being of all citizens.

Rwanda's President, Paul Kagame, delivered these words to the Rwandan public and the international community on 7 April 2020 to launch Kwibuka 26 , the 26th annual commemoration of what is referred to in official parlance as the "1994 genocide against the Tutsi". The genocide occurred at the height of international efforts to negotiate an end to a three-year civil war that had been triggered when the predominantly Tutsi Rwandan Patriotic Front (RPF) - a party composed primarily of descendants of Tutsi refugees who had fled earlier periods of political violence in Rwanda - invaded northern Rwanda on 1 October 1990. The conflict, and broader climate of economic, social and political upheaval, radicalized a cohort of Hutu Power extremists close to Hutu President Juvénal Habyarimana (in power from 1973-94), who began disseminating anti-RPF and anti-Tutsi propaganda aimed at demonizing the RPF and its perceived supporters, Rwanda's Tutsi minority population. Following Habyarimana's unexpected assassination on 6 April 1994 by unknown parties, the Hutu Power extremist-dominated interim government used the resulting chaos as an opportunity to attempt to eliminate political moderates and the nation's minority Tutsi. The genocide lasted approximately three months, culminating with the RPF's military victory on 18 July (Des Forges 1999; Guichaoua 2015; Kimonyo 2016). By this time, the Hutu Power extremists and their supporters had massacred between 500,000 (Des Forges 1999, pp. 15-16; Meierhenrich 2020, p. 81; Straus 2019) and one million (National Commission for the Fight Against Genocide 2013) Rwandans and sexually assaulted an estimated 250,000 women, among other atrocities (Degni-Ségui 1996; Nowrojee 1996). Most of the Hutu Power extremists'

DOI: 10.4324/9781003167280-4 


\section{Erin Jessee}

victims were of Tutsi heritage, but they also targeted "internal enemies": the Tutsi's perceived supporters among the Hutu majority and indigenous Twa minority (Eltringham and Van Hoyweghen 2000, p. 226; see also Laws et al. 2019; Lewis and Knight 1995, pp. 26-7).

The 1994 genocide represents one of the few examples of mass atrocity since the Holocaust that has met the legal criteria established by the United Nations Convention on the Prevention and Punishment of the Crime of Genocide (1948). Internationally, legal accountability was partially pursued via the nowdefunct International Criminal Tribunal for Rwanda (ICTR). However, the RPF's transitional government has also pursued an ambitious transitional justice programme comprised of national trials and an adapted dispute resolution mechanism known as gacaca ("justice on the grass") (Doughty 2016; Gahima 2013; Ingelaere 2016). Additionally, the government has increasingly invested in a comprehensive national commemoration programme that includes eight major genocide memorials and provides support for nearly 250 district-level genocide memorials that are maintained by local communities (National Commission for the Fight Against Genocide 2020). These memorials - the focus of this chapter - are integral to official genocide commemoration in Rwanda. They have been designed to adhere to key international transitional justice principles: providing survivors with a safe place to remember their missing and murdered loved ones; educating the public about Rwandan history leading up to the genocide, including the dangers of "bad governance" and ethnic divisionism; and providing irrefutable evidence - most notably through the displaying of visibly traumatized anonymous human remains and personal effects - that the violence that overwhelmed Rwanda in 1994 constitutes genocide (Jessee 2017, p. 46). The memorials thus serve as focal points for official genocide commemoration and education.

Kagame's speech for Kwibuka 26 cited in the opening passage similarly aligns with many key principles of international transitional justice, most notably by appealing to Rwandans' sense of shared national heritage and encouraging them to learn from those aspects of Rwandan history that made the genocide possible to prevent future genocidal violence. However, Kagame's words obscure the ongoing controversy that surrounds nationalized genocide commemoration in Rwanda, as commemorative sites and ceremonies have evolved to recognize an increasingly limited and politicized version of events, which perpetuates a "nationalism-within-a-nationalism" (Baldwin 2019, p. 2). Scholars have studied nationalized commemoration in Rwanda from various disciplinary perspectives (see, for example, Burnet 2009; Friedrich and Johnston 2013; Guyer 2009; Ibreck 2013; King 2010; Major 2015; Meierhenrich 2011; Mwambari 2019; Vidal 2004; and Viebach 2019). Anthropologist Claudine Vidal (2004) was one of the earliest scholars to study Rwanda's memorials, and argued that they were becoming a source of symbolic violence that silences survivors' lived experiences and dictates how they interact with their murdered loved ones. Soon afterwards, transitional justice scholar Susanne Buckley-Zistel (2006, p. 131) found that the 
memorials and related commemorative practices were prompting Rwandans to practise "chosen amnesia" - a survival mechanism that enables peaceful coexistence while failing to challenge "the social cleavages that rendered the genocide possible in the first place, and so obstructing their transformation in the future". Anthropologist Jennie Burnet (2012, p. 128) subsequently argued that the official narrative upheld by Rwanda's national commemorative sites and events promoted "a clear yet sometimes arbitrary demarcation between Hutu and Tutsi" that recognizes only Tutsi victims, while condemning the Hutu majority as perpetrators.

This critical research speaks to two key themes in the literature on official genocide commemoration in Rwanda: the state-imposed official narrative of the genocide and the silences that it inevitably imposes on those Rwandans whose experiences do not neatly align with this narrative; and the ensuing question of whether the Rwandan government's increasingly politicized approach to commemoration can truly facilitate genuine social repair and long-term political stability in the region. However, a politicized approach to commemoration is by no means unique to Rwanda (see, for example, Drozdzewski et al. 2016; Rose 2016; Sodaro 2018; Winter 2007; see also Chapter 2 in this volume), nor are these themes without their own critics. As noted by peace-building scholar David Mwambari (2019, p. 2), studies of individual Rwandans' efforts to commemorate their experiences of the genocide, using music and the arts, have been largely eclipsed by studies of genocide memory "at the centre of national politics, foreign policy-making and socio-economic programs in what has a become an authoritarian political climate" (see also Longman and Rutagengwa 2006; Viebach 2019). Those few studies that focus on, or include, analysis of Rwandan genocide commemoration "from below" reveal the "limits of a government's ability to shape the collective memory of a population", highlighting the need for more complex, multilayered analysis that goes beyond ethnic identities to consider political, regional, gender and other salient markers of identity in Rwanda (Longman and Rutagengwa 2006, p. 243). Indeed, individual survivors and their narratives have been, and remain, significant actors who inform Rwanda's official narrative of the genocide - even in instances where they recognize the official narrative's inability to adequately represent the diverse experiences of the genocide and the significant challenges it poses for promoting genuine national unity and reconciliation in Rwanda (Jessee 2017, pp. 81-116). As political scientist Rachel Ibreck (2012, p. 99) reminds us, "we must expect fractured memory in Rwanda", given people's polarizing experiences of genocide and related mass atrocities in the 1990s.

\section{The first national genocide commemorations}

The effects of people's polarizing experiences, and the fractured memory that has resulted, became evident with Rwanda's first efforts to commemorate the genocide. Immediately after its military victory, the RPF established a 
government of national unity led by Hutu President Pasteur Bizimungu and Tutsi Vice President Paul Kagame. Central to their government's platform was the promotion of a shared national identity, which they argued should obliterate the ethnic identities that had increasingly divided Rwandans in the 20th century (Blackie and Hitchcott 2018, p. 24; Benda 2019, p. 191). Burnet (2012, p. 96) notes that the first national genocide commemoration in April 1995 at Kigali's National Amahoro Stadium "promoted the ideology of national unity through representation of both Tutsi and Hutu victims of the genocide". The ceremony included the burial of 6,000 anonymous victims of the genocide, as well as recognition of national heroes such as former Prime Minister Agathe Uwilingiyimana - the moderate Hutu politician who had been slated to succeed Habyarimana (Burnet 2019; Guichaoua 2015, pp. 214-20) - who was murdered by Hutu Power extremists on 7 April 1994 to eliminate resistance to the genocidal interim government they were forming. This first commemoration aligned with the broader tendency in official state discourse and Rwandan popular culture to reference itsembabwoko n'itsembatsemba ("genocide and massacres"): phrasing that not only acknowledged Tutsi victims of genocide, but also Hutu and Twa who were murdered during the genocide for resisting Hutu Power ideology or by the RPF as it wrested control of Rwanda, among other forms of political violence (Burnet 2012, p. 20).

Meanwhile, across Rwanda the government partnered with formal and informal genocide survivors' associations that emerged shortly after the genocide ended - the most prominent of which is the umbrella organization Ibuka founded in December 1995 - to create genocide burial grounds and memorials in their communities. This set an important precedent for the creation of small-scale genocide memorials throughout Rwanda, as well as the larger national memorials that since 2007 have been administered by the National Commission for the Fight Against Genocide (CNLG). Ibreck (2010, p. 336) argues that while survivors gained an important political platform through these institutions and associated activities, they saw this early memory work "as a response to loss and ... first and foremost an expression of grief and a practice of mourning", a kind of "memory-justice" (see also Viebach 2020, p. 240). Survivors' organizations worked with the government to locate mass graves and related sites where the Hutu Power extremists disposed of their deceased victims' bodies, and exhume, clean and rebury with respect the human remains they found - an important form of "care-taking" for survivors' loved ones (Viebach 2019, p. 278; see also Major 2015, p. 165). Fabrice, a child survivor of the massacre at Kibuye Roman Catholic Church in western Rwanda, remembered the process in his community as follows:

What we did is just to collect all the human remains, clean them and bring them to the memorials. While collecting the bones, we didn't identify who those people were. Everybody treated the bones as though 
they belonged to his or her family. It was participatory work, where even those who didn't know where their people were buried contributed.

(Jessee 2012, p. 10) ${ }^{1}$

Vidal (2001, p. 4, author's translation) argues that while such practices represented a "radical symbolic rupture" from earlier Rwandan traditions associated with respectful treatment of the dead, many survivors embraced this change because they believed it served "an existential purpose: the will to restore the deceased's human dignity, a dignity that the instigators and perpetrators of the genocide had denied both with their propaganda and by the cruelty of the suffering they had inflicted upon their victims". Which is not to say, of course, that these exhumations were easy for the people who participated in them. During fieldwork I conducted between 2007 and 2012, most of the Rwandan survivors whom I interviewed recalled these exhumations, and the memorial sites at which the exhumed human remains were eventually reburied, as sources of significant spiritual and emotional distress (Jessee 2012, 2017, pp. 107-9). I found that this distress often persisted despite the underlying intent of the exhumations to prevent the "ills, troubles and misfortunes" that Rwandans feared would come from "deaths for which funeral rites and formal mourning practices are not possible" (Bagilishya 2000, p. 347).

Indeed, the early commemorative initiatives around which these reburials occurred often proved controversial and painful for Rwandans and contributed to heightened tensions in many communities. A key source of tension, in addition to the challenges of exhuming and anonymizing Rwanda's countless mass graves, related to the tendency for these events to be inclusive of the victims of the genocide and related mass atrocities in 1994. In Butare in December 1994, for example, Vidal recalls that the Catholic diocese asked its community to help create a list that included the names of Tutsi and Hutu victims of the genocide and war. In doing so, it acknowledged that many Rwandans would find this process challenging because it required a "renouncement of the natural inclination to seek revenge", but stressed that it was essential to overcome the "evil" that had overwhelmed Rwanda (Vidal 2004 , p. 2). This was followed by survivor-led efforts to disinter the anonymous dead from local mass graves and to rebury them with respect.

Unsurprisingly, the diocese's efforts to encourage recognition of the genocide and related mass atrocities encountered challenges, including a persistent silence within some communities when people were asked to divulge the locations of mass graves. In October 1995, the diocese claimed that "the refusal to divulge [the location of] these [mass graves] is due to the fear of reprisals by genocide survivors or the authorities" (Vidal 2004, p. 4). When they found mass graves and people were able to rebury the remains that they exhumed, in the subsequent ceremonies "verbal abuse prevailed over mourning", as officials condemned the Hutu as a community for perpetrating genocide and survivors publicly accused the people whom they held 
responsible for torturing and/or murdering their loved ones (p. 2). Additionally, the inclusion of public discussion of Hutu victims, especially those who were allegedly murdered by the RPF's military arm - the Rwandan Patriotic Army (RPA) - soon triggered official disapproval. These crimes "were so violently denied by the RPF that their evocation became the subject of a taboo that was dangerous to transgress" (p. 4).

Thus, the Rwandan government was compelled to take control of exhumations and resulting commemorative sites and activities, circumnavigating the questionable authority of the Catholic Church in such matters (Kubai 2007; Longman 2010; Van Hoyweghen 1996). The government's initial involvement, however, fuelled controversy as it began to use prisoners including accused génocidaires - to exhume and transport human remains to the sites of future memorials, even in instances where survivors had already identified their murdered loved ones and held appropriate funerals. Vidal (2004, p. 5) argued that the government's methods created "a climate of revenge more than a demand for justice", which was then reinforced during the 1996 national commemoration. While the previous year's ceremony had focused on Rwandan victims of all ethnicities, during the 1996 national commemoration a Tutsi survivor gave his testimony, after which he began pointing to people in the crowd who he claimed had killed (p. 7). Burnet (2012, p. 101) argues that this ceremony set an important precedent for distinguishing Tutsi genocide victims and survivors from the RPF "rescuers" and Hutu perpetrators - a pattern that persists to the present day, even as other aspects of national commemorations have evolved.

\section{Towards commemoration of the "1994 genocide against the Tutsi"}

To this end, when I first started conducting fieldwork in Rwanda in 2007, the nation was on the verge of a dramatic shift in official discourse related to the genocide, as the government was introducing the exclusive terminology Jenoside yakorewe Abatutsi ("the genocide against the Tutsi"). Martin Ngoga (2020) - the former Prosecutor General for Rwanda and a former Special Representative to the ICTR - argues that use of this terminology is supported by ICTR jurisprudence, while failing to use it "is dangerous as it feeds into an already resurgent denialist movement in the region and internationally". Similarly, Rwandan officials and survivors' organizations often cite a moral argument that equates the recognition of non-Tutsi victims of the genocide, or the discussion of the other forms of political violence that occurred around the 1994 genocide, with a kind of genocide denial (see, for example, Rugira 2020).

This resulting shift in discourse was documented by Ibreck (2012, p. 103), who concluded that it "alters the context in which the commemorations take place and means that Tutsi victimhood is now securely established in public discourse". This was followed in 2009 by the CNLG's decision to name the annual official commemoration ceremony Kwibuka ("to remember"), 
accompanied by appropriate branding for the event. The associated activities, and form and phrasing of the resulting signage and related souvenirs is strictly controlled by the CNLG, which removes any materials that do not conform. The effect is that "visual and aural reminders of ethnicity and violence appear overnight on 7 April and disappear just as quickly overnight on 3 July" (Baldwin 2019, p. 11).

The years immediately surrounding these amendments to the national genocide commemoration in Rwanda were tense. As the Rwandan government began use the media to sensitize Rwandans and the international community as to why the official label was more appropriate, Rwandans from a range of backgrounds relative to the conflict expressed concerns. They feared that this label obscured recognition of the Hutu and Twa political moderates who were murdered from 6 April onwards, as well as the Hutu and Twa civilians who were murdered for trying to resist the genocidal violence. It was felt that such details ought to be highlighted rather than obscured if the goal was to promote genuine national unity and reconciliation (Jessee 2017, pp. 512). This concern arose amid the broader tensions people noted as the state exercised increased authority over national commemorative sites and activities across Rwanda. For example, Consolée - an employee at one of the national memorials - was initially dismissive of questions about the level of public support for the memorials, arguing:

We [survivors] prefer our people to stay at memorials as physical evidence of the genocide, and also we want people from abroad like you to tell others what happened. We want our history to be remembered by the younger generations of Rwandans and also by the entire world.

However, Consolée later acknowledged that displaying human remains or burying genocide victims in mass graves was culturally inappropriate and a source of tension within her community, because these practices had been given priority over even tentatively identifying the victims. She claimed to know many people who believed that they were haunted by the disrespected spirits of family members who had gone missing during the genocide, or were distressed by the possibility that their loved ones might still be alive somewhere:

The harms come when a survivor thinks that maybe his or her people have been eaten by wild dogs or have been buried in a disrespectful way, or maybe they are still alive and are living somewhere else since you are not really sure where they are buried ... It happens to some people: you may hear someone speaking to his or her relative who died. Most of the cases are traumatized people. And also there are some people who dream while they are awake. When you talk to them, they say they were talking to their dead relatives. 
Consolée concluded that if the government dedicated resources to locating, identifying and allowing survivors to repatriate the anonymous victims of the genocide according to their preferences - whether in single burials on ancestral land according to tradition or in the memorials - it would go a long way towards repairing some of the psychological and spiritual damage endured by genocide survivors.

Other memorial staff whom I interviewed were similarly divided on the subject of the memorials' prominent displays of human remains, though all of them acknowledged its negative potential for those survivors who associated "traditional" burials by their family's standards with closure and demonstrating respect for deceased loved ones. For example, Solange - a young survivor who interpreted her work at a genocide memorial as essential for preventing future bloodshed - was conflicted about the site's graphic displays of human remains. She maintained that it was important to show visitors physical evidence of the genocide, noting that "I want people to understand that genocide really happened, because some people doubt it ever took place or deny it. My aim is to make them realize the enormity of what happened" (Jessee 2017, p. 108). She defended the government's decision to display genocide victims' remains or to inter them in mass graves, explaining:

In our tradition, when somebody dies, family and friends gather for the burial ceremony. There is a specific number of days of mourning. Once this period is past, the family returns to everyday business. It's over. But following genocide, you bury a person you are not even sure is your relative. Sometimes you are told that your loved ones were thrown or buried in a particular place and when you search, you don't find them. Sometimes you find body parts scattered all over, and you collect the head here, the legs there ... So what we do is we collect all remains and bring them to the memorial. In essence, we are not in opposition to tradition. We are just being practical, adapting to the special situation of genocide.

However, Solange admitted that the government's treatment of the anonymous dead at the memorials had alienated the wider community where she worked, particularly following the 2008 entry into force of a law that required all genocide victims' remains to be reburied at a local memorial (Government of Rwanda 2008). For this reason, Solange alternated between respecting the government's decision to prioritize displaying human remains as physical evidence of the genocide, and empathizing with those survivors for whom the memorials had become a source of anguish, for forcing them to interact with their dead in a manner that defied individual preferences for the respectful treatment of the dead. Solange claimed she had, on occasion, seen survivors take small bones and pieces of clothing from the memorial, presumably with the intention of reburying them on their ancestral lands as a means of facilitating closure or appeasing the angry spirits of their dead. 
And while she acknowledged that people were not supposed to speak about such things, she also admitted that many members of her community, regardless of ethnicity, were angered by the thought of Tutsi victims of the genocide being buried alongside Hutu victims of RPA atrocities - particularly alleged génocidaires who had been murdered by RPA troops - at the memorials (see also Des Forges 1999, pp. 701-35).

Similar concerns emerged from the countless unrecorded casual conversations and related ethnographic encounters that I have had with Rwandans from different ethnic backgrounds since 2007. A central theme within these conversations related to the possible negative impact that the displays of anonymous human remains could have on the lives of the people who came into contact with them. While over the years most of these displays have been protected behind clear plastic or glass, prior to 2012 it was still common for bones to be stacked on open shelves at the genocide memorials, so that visitors could pick them up and examine them as evidence. When speaking with Rwandans about Kwibuka, several people admitted that they feared the memorials because they were worried about the consequences of coming into contact with the remains of people whose blood had been shed in violence. I was frequently told that the spirits of people who had died violent deaths were particularly dangerous, because these angry spirits would lash out at anyone with whom they came in contact - including their own surviving family members - if they felt their remains were being treated disrespectfully. This belief seemed particularly prevalent among the convicted génocidaires I interviewed, who frequently referenced the belief that the blood of their victims was capable of "chasing them". Three convicted génocidaires whom I interviewed in the prisons where they were serving sentences for genocide-related crimes spoke at length about nightmares, unpredictable mood swings and other psychological symptoms, which they attributed to having come into direct contact with the blood of their victims (Jessee 2017, p. 168).

I similarly encountered many Rwandans who avoided going to their local memorials because they perceived these sites to be spiritually dangerous. Such concerns were widespread across Rwanda, but seemed particularly common among the people I encountered around Bisesero - where Tutsi civilians launched a famous resistance against the Hutu Power extremists during the genocide (Gasana 2019). There, I met several people who claimed to have seen or experienced the negative effects of living alongside the angry spirits of people who had died in the resistance. Boniface, a Hutu man who had grown up in Bisesero, recalled that many people were afraid to go to Bisesero because "maybe the ghosts of dead people [referring to the victims of the genocide and related mass atrocities] would attack us". However, he also acknowledged that people sometimes feared these places because "after the genocide, we though there were some killers [referring to Hutu Power extremists] who were still killing people inside the forest, and also survivors [referring to RPA combatants and genocide survivors] who wanted revenge against us [referring to the local Hutu]". When speaking with other 
community members, however, concerns regarding angry spirits seemed more prominent than the risk of violence from Hutu Power extremists or vengeful survivors, perhaps because these risks had dissipated over the years. Conversely, the threat from angry spirits seemed ongoing, inflicting a range of mental and physical illnesses on community members who farmed in places where victims' bodies had been left, as well as allegedly causing infertility among the cattle and goats that the locals attempted to rear. Some people had continued farming in the area out of necessity. However, it seemed that they had negotiated a fragile peace with the angry spirits, whom they were quick to blame for any undue suffering.

These casual conversations touched upon an additional source of tension associated with the memorials, namely the prospect that due to the absence of definitive identification of the anonymous dead interred at the memorials, it was likely that Tutsi victims of the genocide had been interred alongside the Tutsi, Hutu and Twa victims of the mass atrocities perpetrated in the region in the 1990s, as evidence of the "1994 genocide against the Tutsi" (see also Guichaoua 2020, pp. 130-6; Straus 2019). Related concerns were shared with me by Rwandans from a range of ethnic and political backgrounds in unrecorded conversations. Several survivors expressed overt horror at the idea that their missing and murdered loved ones might be interred alongside the same people who murdered them, and cited concerns that this might prevent the genocide's "real victims" from finding peace in the afterlife. Interestingly, I found that several bystanders and convicted génocidaires of Hutu heritage or mixed ethnicity shared similar beliefs, but with anguish and resentment emerging from their perception that their loved ones, who had died in the broader political violence that occurred in the region in the 1990s, would never receive the same recognition afforded to Tutsi genocide victims. Indeed, the arrest and conviction of Victoire Ingabire - a woman of mixed Rwandan heritage and a prominent member of Rwanda's political opposition - for minimizing the genocide, among other allegations, was probably prompted by her 2010 speech at the Kigali Genocide Memorial, during which she noted,

if we look at this memorial, it only stops at people who died during the Tutsi genocide. It does not look at the other side - at the Hutus who died during the genocide. Hutus who lost their people are also sad and they think about their lost ones and wonder, 'When will our dead ones be remembered?'.

(Ingabire 2010; see also Al Jazeera 2018; BBC 2012)

\section{Conclusion: the challenges of commemoration in authoritarian contexts}

Unsurprisingly, given the myriad tensions that surround genocide commemoration in Rwanda, the nation's state-funded memorials and commemorative activities remain in a state of flux. Some changes are in direct response to feedback - both positive and negative - that the CNLG and the 
Rwandan government more generally has received from survivors. For example, in response to concerns that working at the memorials was too challenging for people who had survived, or whose loved ones had been murdered, the Rwandan government introduced a training programme that provides memorial staff with coping strategies for handling the negative psychological consequences of long-term work at these sites (Jessee 2017, pp. 87-8). The government has also increasingly funded improvements and/or renovations of the nation's smaller and more remote memorials, to ensure that evidence of the genocide is preserved. This has typically included placing small displays of anonymous human remains behind clear plastic or glass, and interring all other remains in coffins placed in cement-covered mass graves or crypts, so that people no longer come into direct contact with human remains. Where such improvements are impossible, smaller memorials are incorporated into larger, more sustainable sites. These measures are informed by the Rwandan government's efforts since 2017 to promote agaciro (dignity): a concept that also expresses state ambitions for Rwanda's future beyond commemoration (Bolin 2019). Simultaneously, policy analyst Gretchen Baldwin (2019, p. 10) argues that, since 2014, the Rwandan government has facilitated a shift "from larger, state-performed commemoration events to more intimate community-based events". This allows people to engage with national commemoration in accordance with their personal preferences, facilitating a more multilayered and dynamic Kwibuka period. These changes support Ibreck's (2012, p. 99) argument:

[T] he government cannot impose its authority through commemoration, which necessarily is an opportunity for other voices to be heard. Official efforts to cultivate a selective memory are successful only in part ... public memory serves as the focus for popular demands for justice and rights and therefore acts as a channel for posing challenges to the regime.

However, concerns persist that, amid these important changes in commemorative practices, the Rwandan government continues to prioritize its political interests at the expense of genuine national unity and reconciliation. The state's ongoing efforts to lobby the international community to adopt its official label for the "1994 genocide against the Tutsi" continue to encounter resistance, even as it meets with significant success. As part of these efforts, in 2012, the Rwandan government nominated the genocide memorials at Nyamata, Murambi Bisesero and Kigali to the UNESCO World Heritage List, though UNESCO continues to deliberate their addition (Bolin 2020, p. 200; UNESCO 2012). Extensive international lobbying by the Rwandan government and various Rwandan survivors' organizations subsequently prompted the United Nations General Assembly, in 2018, to rename 7 April "the International Day of Reflection on the 1994 genocide against the Tutsi in Rwanda", even as it encourages participants to acknowledge the Hutu and Twa who died in opposition to the genocide (United Nations 2018). Various 
nations are now debating whether to adopt this language in state discourse: for example, in 2019 the Belgian government set an important precedent by criminalizing denial of the 1994 genocide against the Tutsi (Bizimungu 2019). However, concerns persist internationally that uncritically adopting this label contributes to obscuring non-Tutsi victims of the genocide, and silencing people's experiences of the broader human rights violations that surrounded the genocide in the 1990s. For example, Baldwin concluded that the Rwandan government's current approach to commemoration reinforces "a survivor nationalism diametrically opposed to the homogeneity of the rest of the year", by which she means official efforts to facilitate a shared national identity among Rwandans through eschewing divisive ethnic labels (2019, p. 3).

The case of Rwanda thus raises provocative questions about the potential for genuine social repair - a key intended outcome of transitional justice - to be realized through official commemorative activities and sites, especially when commemorations are informed by regimes that see no benefit to acknowledging the complexity of people's experiences surrounding genocide, as well as broader atrocities that might have occurred in addition to genocide. In other contexts, such as post-civil war Uganda, transitional justice scholars have argued that creating culturally appropriate public spaces in which people can talk about their complex first-hand experiences of violence allows storytelling to restore social equilibrium (see, for example, Baines and Stewart 2011). More generally, anthropologists Veena Das and Arthur Kleinman (2001, p. 6) have maintained that "[f]inding one's voice in the making of one's history, the remaking of a world ... is also a matter of being able to re-contextualize the narratives of devastation and generate new contexts through which everyday life may become possible". However, in considering the possibility that creating space for people to speak earnestly about their complex experiences of genocide and related mass atrocities, it is important to heed anthropologist Kirstin Doughty's (2015, p. 432) warning that, while it might be tempting to imagine that there are some post-conflict contexts "where a kinder, gentler reconciliation can occur, absent power relations of age, gender, class, or other forms of silencing", in many contexts "the work of building and rebuilding social networks among "intimate enemies" ... is contentious, suffused with hostility and instrumentality". Thus, it is unlikely that official commemorations and other collective forms of remembering mass atrocities, whatever form they may take in future, will ever prove satisfying to everyone - a point that transitional justice scholars and practitioners would do well to remember in evaluating the "success" of efforts to promote social repair in post-genocide contexts.

\section{Note}

1 All interviewees' names have been replaced with pseudonyms in accordance with their individual preferences and the terms of the informed consent process underlying the author's fieldwork in Rwanda. 


\section{References}

Al Jazeera. "Rwanda opposition leader among 2,100 released from prison". Al Jazeera, 14 September 2018, www.aljazeera.com/news/2018/9/15/rwandan-opposi tion-leader-among-2100-released-from-prison. Accessed 17 February 2021.

Bagilishya, Déogratias. "Mourning and recovery from trauma: In Rwanda, tears flow within". Transcultural Psychiatry, vol. 37, no. 3,2000, pp. 337-353.

Baines, Erin, and Beth Stewart. "I cannot accept what I have not done': Storytelling, gender, and transitional justice". Journal of Human Rights Practice, vol. 3, no. 3, 2011, pp. 245-263.

Baldwin, Gretchen. "Constructing identity through commemoration: Kwibuka and the rise of survivor nationalism in post-conflict Rwanda". Journal of Modern African Studies, vol. 57, no. 3, 2019, pp. 1-21.

BBC. "Rwandan opposition leader Victoire Ingabire jailed". BBC, 30 October 2012, www.bbc.co.uk/news/world-africa-20138698. Accessed 17 February 2021.

Benda, Richard. "Promising generations: From intergenerational guilt to Ndi Umunyarwanda". Rwanda since 1994: Stories of change, edited by Hannah Grayson and Nicki Hitchcott. Liverpool, Liverpool University Press, 2019, pp. 189-210.

Bizimungu, Julius. "How significant is Belgium's move to criminalise genocide denial?" The New Times, 10 April 2019, www.newtimes.co.rw/news/how-significa nt-belgiums-move-criminalise-genocide-denial. Accessed 25 January 2021.

Blackie, Laura, and Nicki Hitchcott. "II am Rwandan': Unity and reconciliation in post-genocide Rwanda". Genocide Studies and Prevention, vol. 12, no. 1, 2018, pp. 24-37.

Bolin, Annalisa. "Dignity in death and life: Negotiating agaciro for the nation in preservation practice at Nyamata Genocide Memorial, Rwanda". Anthropological Quarterly, vol. 92, no. 2, 2019, pp. 345-374.

Bolin, Annalisa. "Imaging genocide heritage: Material modes of development and preservation in Rwanda". Journal of Material Culture, vol. 25, no. 2, 2020, pp. 196219.

Buckley-Zistel, Susanne. "Remembering to rorget: Chosen amnesia as a strategy for local coexistence in post-genocide Rwanda". Africa, vol. 76, no. 2, 2006, pp. 131150.

Burnet, Jennie. Genocide lives in us: Memory and Silence in Rwanda. Madison, University of Wisconsin Press, 2012.

Burnet, Jennie. "Uwilingiyimana, Agathe". Oxford Research Encyclopedia of African History. London, Oxford University Press, 2019.

Burnet, Jennie. "Whose genocide? Whose truth? Representation of victim and perpetrator in Rwanda". Genocide: Truth, memory, and representation, edited by Alexander Hinton and Kevin O’Neill. Durham, NC, Duke University Press, 2009, pp. 80-110.

Das, Veena, and Arthur Kleinman. "Introduction". Remaking a world: Violence, social suffering, and recovery, edited by Veena Das and Arthur Kleinman. Berkeley, University of California Press, 2001, pp. 1-30.

Degni-Ségui, René. "Report on the situation of human rights in Rwanda, submitted by Mr. René Degni-Ségui, Special Rapporteur of the Commission on Human Rights, under paragraph 20 of Resolution S-3/1 of 25 May 1994”. United Nations Commission on Human Rights, 29 January 1996, http://hrlibrary.umn.edu/comm ission/country52/68-rwa.htm. Accessed 25 January 2021. 
Des Forges, Alison. Leave none to tell the story: Genocide in Rwanda. New York, Human Rights Watch, 1999.

Doughty, Kristin. "Law and the architecture of social repair: Gacaca days in postgenocide Rwanda". Journal of the Royal Anthropological Institute, vol. 21, no. 2, 2015, pp. 419-437.

Doughty, Kristin. Remediation in Rwanda: Grassroots legal forums. Philadelphia, University of Pennsylvania Press, 2016.

Drozdzewski, Danielle, Sarah De Nardi, and Emma Waterton. Memory, place and identity: Commemoration and remembrance of war and conflict. London, Routledge, 2016.

Eltringham, Nigel, and Saskia Van Hoyweghen. "Power and identity in post-genocide Rwanda". Politics of Identity and Economics of Conflict in the Great Lakes Region, edited by Ruddy Doom and Jan Gorus. Brussels, VUB University Press, 2000, pp. 215-242.

Friedrich, Mona, and Tony Johnston. "Beauty versus tragedy: Thanatourism and the memorialisation of the 1994 Rwandan genocide". Journal of Tourism and Cultural Change, vol. 11, no. 4, 2013, pp. 302-320.

Gahima, Gerald. Transitional justice in Rwanda: Accountability for atrocity. London, Routledge, 2013.

Gasana, Oscar. Les collines se souviennent: Les rescapés de Bisesero racontent leur résistance, deux décennies après le génocide des Tutsi du Rwanda. Kigali, Izuba, 2019.

Government of Rwanda. Law No. 56/2008 of 10/09/2008 Governing Memorial Sites and Cemeteries of Victims of the Genocide Against the Tutsi in Rwanda. Kigali, Government of Rwanda, 2008.

Guichaoua, André. "Counting the Rwandan victims of war and genocide: Concluding reflections". Journal of Genocide Research, vol. 22, no. 1, 2020, pp. 125-144.

Guichaoua, André. From war to genocide: Criminal politics in Rwanda, 1990-1994. Madison, University of Wisconsin Press, 2015.

Guyer, Sara. "Rwanda's bones". Boundary 2, vol. 36, no. 2, 2009, pp. 155-175.

Hintjens, Helen. "Post-genocide identity politics in Rwanda". Ethnicities, vol. 8, no. 1, 2008, pp. 5-41.

Ibreck, Rachel. "International constructions of national memories: The aims and effects of foreign donors' support for genocide remembrance in Rwanda". Journal of Intervention and Statebuilding, vol. 7, no. 2, 2013, pp. 149-169.

Ibreck, Rachel. "The politics of mourning: Survivor contributions to memorials in post-genocide Rwanda”. Memory Studies, vol. 3, no. 4, 2010, pp. 330-343.

Ibreck, Rachel. "A time of mourning: The politics of commemorating the Tutsi genocide in Rwanda". Public memory, public media and the politics of justice, edited by Philip Lee and Pradip Thomas. London, Palgrave Macmillan, 2012, pp. 99-120.

Ingabire, Victoire. Unity and reconciliation speech at Gisozi Genocide Memorial Centre. 2010. www.victoire-ingabire.com/Eng/victoires-quotes/. Accessed 17 February 2021.

Ingelaere, Bert. Inside Rwanda's gacaca courts: Seeking justice after genocide. Madison, University of Wisconsin Press, 2016.

International Criminal Court. "Rome Statute of the International Criminal Court". 1998, www.icc-cpi.int/resource-library/documents/rs-eng.pdf. Accessed 25 January 2021.

Jessee, Erin. Negotiating genocide in Rwanda: The politics of history. Cham, Palgrave Macmillan, 2017. 
Jessee, Erin. "Promoting reconciliation through exhuming and identifying victims in the 1994 Rwandan genocide". Discussion Paper Series no. 4, Waterloo, ON, Centre for International Governance Innovation, 2012, pp. 2-22.

Jessee, Erin. "Rwandan women no more: Female genocidaires in the aftermath of the 1994 Rwandan genocide”. Conflict and Society, vol. 1, 2015, pp. 60-80.

Kagame, Paul. "Speech on the occasion of 26th commemoration of genocide against Tutsi". The New Times, 7 April 2020, www.newtimes.co.rw/news/speech-president-ka game-launch-26th-commemoration-genocide-against-tutsi. Accessed 25 January 2021.

Kimonyo, Jean-Paul. Rwanda's popular genocide: A perfect storm. Boulder, CO, Lynne Rienner Publishers, 2016.

King, Elisabeth. "Memory controversies in post-genocide Rwanda: Implications for peacebuilding". Genocide Studies and Prevention, vol. 5, no. 3, 2010, pp. 293-309.

Kubai, Anne. "Post-genocide Rwanda: The changing religious landscape". Exchange. vol. 36, 2007, pp. 198-214.

Laws, Meghan, Richard Ntakirutimana, and Bennett Collins. "One Rwanda for all Rwandans': (Un)covering the Twa in post-genocide Rwanda”. Rwanda since 1994: Stories of change, edited by Hannah Grayson and Nicki Hitchcott. Liverpool, Liverpool University Press, 2019, pp. 125-145.

Lewis, Jerome, and Judy Knight. "The Twa of Rwanda: An assessment of the situation of the Twa and promotion of Twa rights in post-war Rwanda". Chadlington, World Rainforest Movement and International Work Group for Indigenous Affairs, 1995.

Longman, Timothy. Christianity and genocide in Rwanda. Cambridge, Cambridge University Press, 2010.

Longman, Timothy, and Théoneste Rutagengwa. "Memory and violence in postgenocide Rwanda". States of violence: Politics, youth, and memory in contemporary Africa, edited by Edna Bay and Donald Donham. Charlottesville, University of Virginia Press, 2006, pp. 236-260.

Major, Laura. "Unearthing, untangling, and re-articulating genocide corpses in Rwanda”. Critical African Studies, vol. 7, no. 2, 2015, pp. 164-181.

Meierhenrich, Jens. "How many victims were there in the Rwandan genocide? A statistical debate". Journal of Genocide Research, vol. 22, no. 1, 2020, pp. 72-82.

Meierhenrich, Jens. "The transformation of lieux de mémoire in Rwanda". Remaking Rwanda: State building and human rights after mass violence, edited by Scott Straus and Lars Waldorf. Madison, University of Wisconsin Press, 2011, pp. 283-296.

Mwambari, David. "Music and the politics of the past: Kizito Mihigo and music in the commemoration of the genocide against the Tutsi in Rwanda". Memory Studies, vol. 13, no. 6, 2019, pp. 1-16.

National Commission for the Fight Against Genocide. Genocide. 2013, www.cnlg.gov. rw/-Genocide-.html. Accessed 25 January 2021.

National Commission for the Fight Against Genocide. National Genocide Memorial Sites. 2020, https://cnlg.gov.rw/index.php?id=81. Accessed 25 January 2021.

Ngoga, Martin. "Resolution on genocide against the Tutsi offers clarity over the massacre". The East African, 8 June 2020, www.theeastafrican.co.ke/oped/comm ent/Resolution-on-genocide-clarity-over-the-massacre/434750-5571924-159ykv1/ind ex.html. Accessed 25 January 2021.

Nowrojee, Binaifer. Shattered lives: Sexual violence during the Rwandan genocide and its aftermath. New York, Human Rights Watch, 1996.

Rose, Julia. Interpreting difficult history at museums and historic sites. Lanham, MD, Rowman \& Littlefield, 2016. 


\section{Erin Jessee}

Rugira, Lonzen. "Genocide against the Tutsi has passed moral, legal, and political tests". The New Times, 16 April 2020, www.newtimes.co.rw/opinions/genocide-aga inst-tutsi-has-passed-moral-legal-and-political-tests. Accessed 25 January 2021.

Schofield, Hugh. "Rwanda genocide: Kagame 'cleared of Habyarimana crash"”. BBC, 10 January 2012, www.bbc.co.uk/news/world- africa-16472013. Accessed 25 January 2021.

Segal, Aaron. "Massacre in Rwanda". Fabian Research Series, vol. 240, no. 23, 1964, https://repositories.lib.utexas.edu/bitstream/handle/2152/19491/oclc2218385.pdf;seq uence $=2$. Accessed 25 January 2021.

Sodaro, Amy. Exhibiting atrocity: Memorial museums and the politics of past violence. New Brunswick, NJ, Rutgers University Press, 2018.

Straus, Scott. "The limits of a genocide lens: Violence against Rwandans in the 1990s". Journal of Genocide Research, vol. 21, no. 4, 2019, pp. 504-524.

Trédivic, Marc, and Nathalie Poux. "Rapport d'expertise: Destruction en vol du Falcon 50". Cour d'appel de Paris, 2012, http://ddata.over-blog.com/xxxyyy/2/ 93/ 44/38/rapport-ballist-attentat-contre-habyarimana-6-4-19- copie-1.pdf. Accessed 25 January 2021.

UNESCO World Heritage Centre. Sites mémoriaux du génocide: Nyamata, Murambi, Bisesero et Gisozi. 2012, whc.unesco.org/en/tentativelists/5753/. Accessed 25 January 2021.

United Nations. Convention on the Prevention and Punishment of the Crime of Genocide. 1948, https://treaties.un.org/doc/publication/unts/volume\%2078/volume-78-i-1021-engl ish.pdf. Accessed 25 January 2021.

United Nations. General Assembly Designates 7 April International Day of Reflection on 1994 Genocide against Tutsi in Rwanda, Amending Title of Annual Observance. 2018, www.un.org/press/en/2018/ga12000.doc.htm. Accessed 25 January 2021.

Van Hoyweghen, Saskia. "The disintegration of the Catholic Church of Rwanda: A study of the fragmentation of political and religious authority". African Affairs, vol. 95 , no. 380,1996 , pp. 379-401.

Vidal, Claudine. "La commemoration du genocide au Rwanda: Violence symbolique, memorisation force et histoire officielle". Cahiers d"études africaines, vol. 44, no. 175, 2004, pp. 575-592.

Viebach, Julia. "Mediating 'absence-presence' at Rwanda's genocide memorials: Of care-taking, memory and proximity to the dead". Critical African Studies, vol. 12, no. 2, 2020, pp. 237-269.

Viebach, Julia. "Of other times: Temporality, memory and trauma in post-genocide Rwanda”. International Review of Victimology, vol. 25, no. 3, 2019, pp. $277-301$.

Winter, Paul. Memorial museums: The global rush to commemorate atrocities. New York, Berg, 2007. 


\title{
4 Victory celebration and the unmaking of diversity in post-war Sri Lanka
}

\author{
Paikiasothy Saravanamuttu
}

Eleven years after the military defeat of the Liberation Tigers of Tamil Eelam (LTTE or Tamil Tigers), the movement towards transitional justice in Sri Lanka has been, at best, minimal. An Office of Missing Persons and an Office for Reparations have been established, largely as a consequence of international pressure. However, the narrative, in the main, has been one of continued militarization of the civilian space and the shrinking of space for civil society activity, the appointment of past and serving military officers in key civilian positions, the acquisition of land in the minority provinces of the north and east and the continued use of the Prevention of Terrorism legislation (Human Rights Watch 2021; Office of the UN High Commissioner for Human Rights 2021; Centre for Policy Alternatives 2021). Sri Lanka continues to be in a post-war situation in which the guns have fallen silent, rather than in a postconflict situation in which the sources of conflict are no longer sustained and reproduced. With the opening up of a new Sinhala-Muslim fault line, the complex roots of conflict are being further nurtured and sustained.

What lies at the heart of the seeming intractability of conflict and the daunting challenge of conflict transformation in Sri Lanka? The argument has been advanced that one of the key outcomes of the government of Sri Lanka's military victory over the Tamil Tigers in the almost 30-year-long civil war that ended in 2009 is the triumphalist assertion of the ethno-religious political identity of the majority Sinhala community (Fernando 2013; Peiris 2018; Governeur 2010). In this chapter, I will argue that while this happened, the assertion of this majority identity of Sinhala Buddhism has not been discovered or invented on the heels of the military victory in 2009, but it has been nurtured over a longer period. It has progressively come to reside at the very heart of the majority community's self-perception and, consequently, it has become a key contributor to conflict and the sustenance thereof.

\section{The triumphalist moment}

The almost 30-year-long civil war came to an end in May 2009 with the military victory of the Sri Lankan armed forces over the LTTE. However, at this point, even the government maintained that the victory was a military

DOI: $10.4324 / 9781003167280-5$ 
one and not a conclusive end to the ethnic conflict, which was a political issue warranting a political settlement. Therefore, in May 2009, when the guns fell silent, Sri Lanka did pass into a post-war phase but not a postconflict situation in which the roots of conflict could have been addressed and overcome.

Irritated by frequent accusations of wartime human rights violations and war crimes, the Rajapakse government adopted a triumphalist and assertive role, both internationally and domestically. It was eager to present Sri Lanka as one of the few countries, perhaps the only one - and what is more, a country from the global South - to have defeated terrorism. Back at home the government defined for itself the role of the defender of national sovereignty, security and territorial integrity, and the defender of all those who were involved in the defeat of the LTTE.

The news that the LLTE had been defeated was greeted with an outpouring of relief and celebration in the south of the country where the Sinhalese form the majority, with festive milk rice being served on the streets and fireworks set off. Annual independence celebrations in the wake of the defeat of the LTTE prominently include a march featuring the military technology and hardware that were procured in order to win the war, as well as the singing of the national anthem in Sinhala. ${ }^{1}$ Both major political parties - the Sri Lanka Freedom Party (SLFP) and its allies, as well as the rival United National Party (UNP) and theirs - shared in the main the position that no one was going before any tribunal or court to face charges of war crimes. Politicians from both sides vied with each other to proclaim their nationalist credentials and offered to face any tribunal themselves on behalf of the members of the security forces (International Crisis Group 2017).

There were attempts by the Mahinda Rajapaksa regime to consider the initiation of a truth and reconciliation commission and discussions were held with the South African government about how and why it should be established. The South African President Jacob Zuma appointed his deputy, Cyril Ramaphosa (now president of South Africa), as Special Envoy to Sri Lanka. Ramaphosa visited Colombo in July 2014 and met with government leaders and the Tamil National Alliance, but to no avail. The (hesitant) Sri Lankan interest in the South African Truth and Reconciliation Commission (TRC) might have been motivated by the TRC's approach to amnesty, as the Sri Lankan government sought to emphasize restorative justice rather than retributive justice (Jayasuriya 2014; Anketell 2013) Perhaps there was a misunderstanding of the South African process: in effect, the TRC had granted amnesty only to 849 out of 7,112 applications, after full confession and testimonies by both the perpetrators and the victims (Anketell 2013). The South African position with regard to Sri Lanka was that the TRC could not be cherry-picked from a series of recommendable measures for a political settlement and reconciliation.

While ethno-religious nationalist fervour gained salience, the political opposition of the UNP, its allies and sections of civil society were painted as 
being on the wrong side of the patriot/traitor divide and beholden to Western politicians, who were assumed, in turn, to depend on the Tamil diaspora for votes in their respective countries. In addition, the argument was made that the West was envious of Sri Lanka for defeating terrorism. Even as it maintained this position, the Rajapaksa regime could not, however, ignore international opinion and responded in 2010 with the establishment of the Lessons Learned and Reconciliation Commission (LLRC) (Groundviews 2011). However, the tardy implementation of its recommendations formed the basis of the first US-sponsored resolution on Sri Lanka at the Genevabased United Nations Human Rights Council (UNHRC) in 2012. From then on, the UNHRC, where several US-sponsored resolutions on Sri Lanka were presented during the 2012-14 sessions, became the site of increasing international contestation. The regime was not able to muster the majority it did in 2009 to see off a critical resolution in the following years, except when it co-sponsored the resolution in 2015. Opposition to it in Geneva gave the Rajapaksa regime the grounds for renewing the claim that Sri Lanka was being besieged internationally and therefore had to close ranks nationally.

\section{A short window for transitional justice}

By passing an 18th Amendment to the Constitution, Mahinda Rajapaksa removed the two-term limit on the presidency, thereby allowing him to contest an unprecedented third term in 2015. The opposition parties settled on Maithripala Sirisena, the Minister of Health and General Secretary of the SLFP, as their joint candidate. Sirisena had unimpeachable Sinhala Buddhist credentials and could bank on the votes of the minorities as well. Ranil Wickremasinghe, the UNP leader and Leader of the Opposition, was held to be too urban and insufficiently nationalist to hold a candle to Rajapaksa, despite allegations of corruption and nepotism against Rajapaksa and his family. The political space in this respect was bounded by the key requirement of the dominant ideology of the day - that the candidate had have strong Sinhala Buddhist credentials.

Siresena defeated Rajapaksa in January 2015 and appointed Wickremasinghe as his prime minister. Rajapaksa, however, still garnered a considerable number of votes from the majority Sinhala Buddhist community. From the outset, the differences in ideology, background and approach to governance between Siresena and Wickremasinghe made for an unstable and indecisive government. This, along with Rajapaksa's hold on the majority community vote base, facilitated his re-entry into parliament in the general election that followed in August of that year along with the founding of a new party, the SLPP, under his leadership.

The Yahapalanaya (Good Governance) government that was in power from January 2015 to November 2019 nevertheless marked a relative exception from the assertive Sinhala Buddhism promoted by the state. The Sirisena-Wickremesinghe government opened up a front for transitional justice 


\section{4}

Paikiasothy Saravanamuttu

and made a commitment to it at the UNHRC in late September 2015. The Minister of Foreign Affairs, Mangala Samaraweera, proposed to the Council that the Sri Lankan government would establish four mechanisms of transitional justice, namely the Office for Missing Persons, the Office for Reparations, the Truth, Justice and Reconciliation Commission and an accountability commission headed by a special prosecutor, which would include the proactive participation of foreign judges. The latter proposal was met with a storm of protests about national sovereignty and of turning war heroes into war criminals. It gave the Rajapaksas in opposition the argument that they were the only political actors both willing and capable of defending the national interest - defined, yet again, in relation to the interests of the majority community.

In 2016, the government did, however, establish a Consultative Task Force (CTF), composed entirely of civil society representatives, to ascertain the views of the public on transitional justice and the four mechanisms it proposed for its achievement. The CTF asked the government first to address the people, share its vision of transitional justice and reconciliation and explain why it was proposing these four mechanisms. The CTF did in fact draft a speech for the president along these lines but it was never delivered, perhaps because of the political environment of populist nationalism that was prevalent at the time.

As part of the consultative process, the CTF sought to speak to key stakeholders and their representatives. However, attempts to consult the All Ceylon Buddhist Congress were unsuccessful, although a number of monks attended sessions of the CTF at the local level and spoke in particular about the fate of hundreds of monks during the Janatha Vimukthi Peramuna (People's Liberation Front) insurgencies that took place in the south of the country in 1971 and 1988-90. Others were sympathetic to those who sought to disrupt the activities of the CTF, fearing that it would disregard the concerns of the Sinhala Buddhists and report back with preconceived recommendations, or projected that going before the CTF was a waste of time and energy.

The CTF eventually produced a 900-page report and over 45 recommendations, in general and for each of the four mechanisms proposed. The final report of the CTF was to be presented to President Sirisena, but this did not happen and he did not attend the planned handover event. In its recommendations based on consultations with the public - some 7,500 submissions were received in all - the CTF recommended the development of an accountability mechanism with at least one international judge sitting on the bench, on account of the lack of trust and confidence in the Sri Lankan judicial system. This was in conformity with Resolution 30/1 at the UNHRC, which the Sri Lankan government co-sponsored. This recommendation was picked out from among the 40 or so recommendations of the report and rejected. Despite co-sponsoring the resolution in Geneva, the president and prime minister, alongside other leading Sri Lankan politicians, were quick to 
make the point that no member of the armed forces would go before a court or tribunal with foreign judges. This would be a blatant violation of Sri Lanka's sovereignty and national interest. Populist majoritarianism triumphed. However, the Office of Missing Persons was established, as well as, subsequently, an Office for Reparations.

In the 2018 local government elections, the SLPP swept to power in the Sinhala-dominated south. Following the Easter Sunday attacks on churches and luxury hotels by an Islamic group in April 2019, and the government's mishandling of the crisis, the coalition rapidly lost popular support. As the SirisenaWickremasinghe government had restored the two-term limit on the presidency, Mahinda Rajapaksa could not run for office although he was arguably the most popular politician in the country, with political support accruing to him from the disunity and indecisiveness of the Yahapalanaya government. Gotabaya Rajapaksa, former Defence Secretary, brother of Mahinda Rajapakse and a key architect of the victory against the LTTE, was the SLPP presidential candidate in the election of November 2019, which he won with $52 \%$ of the vote. A general election followed in August 2020, in the context of the coronavirus disease (COVID-19) pandemic. The SLPP coalition secured a two-thirds' majority in parliament, dealing a final blow to the country's short-lived experience of considering transitional justice as a societal project.

\section{New fault lines opening up: the Sinhala Buddhist-Muslim conflict}

Apart from the massacre of Buddhist monks in Aranthalawa in 1987 and the attack on the Dalada Maligawa (Temple of the Tooth) in 1998, aimed at severely disrupting the 50th anniversary celebrations of independence, the war between the Sri Lankan state and the LTTE did not have an explicit religious dimension to it. Most Sinhalese and Tamils are pantheists and Sri Lankan Buddhist temples typically accord a place of veneration to Hindu gods.

During the post-war period, however, another site of conflict opened up, this time between the majority Sinhala Buddhist and Muslim communities. This is encapsulated by the rise of the Bodu Bala Sena (BBS - Buddhist Power Force) and its leader, the Venerable Galabodaaththe Gnanasara, and the apparent sponsorship of the BBS by the Rajapaksa regime and the Defence Secretary, Gotabaya Rajapaksa. The impunity afforded to the BBS, despite laws such as the Prevention of Terrorism Act, the Penal Code and the International Covenant on Civil and Political Rights Act available for indictments in respect of hate speech and the incitement to violence, indicate the regime's belief in the notion of Sri Lanka as primarily a Sinhala Buddhist country (Centre for Policy Alternatives 2015, 2018; Wickremesinhe and Hattotuwa 2016). The idea of "unity in diversity" - of the country being made up of a variety of communities different in their own way but wedded to being integral to Sri Lanka - in fact a combination of autonomy and interdependence, was abandoned by state officials. Indicative of this stance is 
that, in September 2014, notwithstanding violence perpetrated against Muslims in Colombo, along the southern coast in Aluthgama and in the Central Province - and despite protests against this violence - the Rajapaksa regime allowed the BBS to invite the incendiary monk Ashin Wirathu from Myanmar to its convention in Colombo (South China Morning Post 2014; Srilal 2014; Schonthal and Walton 2016).

This anti-Muslim sentiment was exacerbated by the Easter Sunday bomb attacks carried out by Muslim extremists, which cost over 250 lives. Simmering tensions were blatantly manifested in the propaganda about Muslim birth rates, halal certification of meat and other products, the reform of the Muslim Marriages and Divorce Act and, most importantly after the Easter Sunday carnage, the issue of wearing the hijab. Although the Easter Sunday bombings were the work of a relatively small number of extremists and the incompetence of the government of the day to act despite having been given clear prior warning and evidence, the issue soon turned into an investigation into the lifestyles and cultural practices of the entire Muslim community. A fast to death by one monk, who had been a member of parliament, was halted when the demand that Muslim ministers resign from the government was met. Attempts by the opposition to keep alive the argument of unity in diversity were grossly inadequate and insufficient, in a context in which the notion of "One Sri Lanka", united and undivided, was given overarching prominence. That "One Sri Lanka" was defined, of course, according to the terms and narrative of the majority Sinhala community.

During the COVID-19 pandemic the issue of the burial or cremation of those who died from the virus arose and caused considerable concern within the Muslim community. Up until March 2021, Sri Lanka did not permit the burial of those who had died as a result of COVID-19 on the grounds that this practice could affect groundwater levels and spread the virus. This stance was contrary to World Health Organization guidelines and flew in the face of local and international scientific opinion. The UN and other international actors called upon the Sri Lankan government to reconsider its position. Governmental committees were set up to resolve the issue and at the time of writing, even though burial was permitted, controversy remained over the location of such burials, leaving the Muslim community convinced that it was being targeted and discriminated against yet again.

\section{The politics of commemoration}

As liberal influences within Sri Lankan politics have waned, Buddhism and the Sangha (priesthood) has gained in salience as legitimizing and galvanizing agents of political affirmation and protest. Consequently, from the belief that those in possession of the Sacred Tooth Relic of the Lord Buddha should rule the country, each decade has seen the further legitimization of Buddhism. This includes the Sangha's participation in the Pancha Balavegaya (Five Great Forces) of the indigenous teachers, farmers, ayurvedic 
doctors, workers and monks that led to the victory of these forces espousing "Sinhala Only" as the official language in 1956, and the monthly calendar based on the full moon (which has significance in Buddhist texts), under which all full moon days were made public holidays in the 1960 s by the Dudley Senanayake government. It also includes taking the presidential oath of office in the Padirruppuwa (octagon) of the Temple of the Tooth in Kandy in 1988 by Ranasinghe Premadasa and Gothabaya Rajapaksa's inauguration, just over three decades later, at the Ruvanveliseya, the iconic Buddhist temple built by the legendary Sinhala hero Dutugemunu. Each of these, together with the coupling of the offices of the president or prime minister with the portfolio for the protection of the Buddha Sasana, attest to the political perception of the indistinguishable nature of the interests of the Sinhala community and Buddhism in Sri Lanka. Every attempt at constitutional reform - even hints at reforming Article 9 of the Constitution which gives Buddhism the foremost place and of declaring Sri Lanka to be a secular state - has always been met with a storm of protest.

During and after the war, in the wake of allegations of war crimes and crimes against humanity by the overwhelmingly Sinhala Buddhist Sri Lankan government armed forces, there was also the belief that the Sinhala Buddhists were the victims of an international conspiracy fuelled by the Tamil diaspora (Rajapaksa 2011; Alagiah 2013; Athas 2009). This sustained and nurtured a strong sense of beleaguerment on the part of the Sinhala Buddhist majority (DeVotta 2016). In turn, this perception underpinned the victories of Mahinda Rakapaksa in the presidential elections of 2005 and 2010, and of his brother Gotabaya in the presidential election of 2019, as the only leaders who could resist Sinhala Buddhist victimization and protect the majority community.

Apart from a few monks, the vast majority of the Buddhist Sangha did not publicly state their aversion or condemnation of the war or the human rights violations it spawned, but argued instead that it was a just war against terrorism and the attempt to secede (see Zuhair 2016). ${ }^{2}$ Accordingly, following the military victory against the Tamil Tigers in May 2009, President Mahinda Rajapaksa was conferred the honour of Vishwa Keerti Sri Sinhaladhishwara (Universally Renowned Overlord of the Blessed Three Sinhala Regions), jointly by the Karaka Sangha Sabhas of the Malwatta and Asgiriya chapters of the Siyam Maha Nikaya. ${ }^{3}$ Accepting the honour, the President noted that he considered himself most fortunate to receive such a high accolade. He stated:

[T] he intention of the Maha Nayake Theras in conferring this honour was to ensure that the united Motherland would be preserved and safeguarded and I solemnly pledge before the Sacred Tooth Relic that I would never allow the bifurcation of the united Motherland. [The distinction was bestowed on me] for once again unifying my country under our National Lion flag. ${ }^{4}$

While the treatment of Tamils and Muslims after the war displayed no predisposition towards reconciliation - with continuing disappearances and 
violation of human rights, land grabs, the engagement, if not the domination, of the civilian economy in the north and the continued insistence on the innocence of the military in respect of allegations of war crimes and crimes against humanity - the affirmation of Sinhala Buddhist identity and its dominance continued apace. The Rajapaksa regime decided to update the historic Sinhala chronicle and epic poem about Sinhala rulers of the island written by the monk Mahanama in the late fifth to early sixth century, the Mahavāmsa, with six new chapters, three of which were to be devoted to the presidency of Mahinda Rajapaksa (Adaderana 2011).

While public commemorations by the families of Tamils who had died in the north and east of the country were banned on the grounds that they constituted celebrative tributes to the LTTE dead, the stationing of the security forces in the north and east, and the building of temples for their worship, was a key part of post-war "reconciliation" by the Rajapaksa regime (Fernando 2010). In June 2013, President Rajapaksa enshrined treasures in the Sandahiru Maha Seya (Triumphant Pagoda), one of nine new pagodas erected in each of the provinces of the island to commemorate the war victory and the heroic soldiers who gave their lives to achieve it. Tamil objections to the erection of Buddhist temples in the predominantly Hindu part of the country were not heeded. In response, Tamils constructed Hindu temples in the north on the grounds that the region was a predominantly Hindu part of the country and had to be appear as such.

Most recently, in June 2020, President Gotabaya Rajapaksa established a Presidential Task Force for Archaeological Heritage Management in the Eastern Province, headed by Archaeological Aryachakravarthi Venerable Ellawala Medhananda Thero, a Buddhist monk. ${ }^{5}$ The Task Force was notably mandated to identify sites of archaeological importance, restore identified sites and antiquities, identify the land that should be allocated for archaeological sites, preserve the cultural value of archaeological sites and promote the country's heritage. No Tamil or Muslim members were appointed to the Task Force in this multi-ethnic province. The assertion of the majoritarian ethno-religious identity was clear, with the agenda of creating the appropriate conditions for the marginalization of the minorities in the Eastern Province and thereby securing it, politically, for the regime. The Venerable Medhananda Thero stated that the goal of the Task Force was to examine and identify some 2,000 sites of Buddhist heritage.

\section{Conclusion}

Transitional justice is unlikely to be delivered anywhere in full in the wake of a military victory. In the Sri Lankan case, the question arises as to whether any significant process of transitional justice can be instituted in the face of the majority community's deep and solid resistance to accountability in particular. While the Mahinda Rajapaksa presidency affirmed that the military victory should be followed by a political settlement of the conflict, it became 
clear that the regime believed otherwise and looked to economic development at best as the substitute for such a settlement. The process of transitional justice was set aside. At the time of writing, following the victory of Gotabaya Rajapaksa in the 2019 presidential election, key positions in government were staffed by serving and former armed forces personnel, some of whom had allegations of war crimes against them. Those measures of transitional justice that had been instituted were largely a consequence of international pressure from the UNHRC and, apart from the period 2015-19, served the purpose of buying time rather than a making a firm commitment to transitional justice.

Buddhism provides an unimpeachable and otherworldly justification for the privileging of Sinhala Buddhist identity in Sri Lanka. This, however, belies some very secular concerns and fears that lead the majority community to espouse it so stridently. In effect, Sinhala Buddhist majoritarianism is also a reaction and backlash against globalization, about the loosening of identities and therefore of the threat to the distinctiveness of a community. It provides a rationale and cover for holding onto economic power and resources.

The new post-war conflict with the Muslim community, prior to the Easter Sunday carnage of 2019, was largely targeted against its economic power and resources. It was mainly Muslim-owned businesses that were targeted, and the propaganda too was aimed at ensuring a boycott of Muslim business establishments. The Muslim stake in the retail trade was at the heart of the attacks about their distinctive cultural practices and of the hysteria about reproductive rates, which were alleged to be the means to replace the majority Sinhala Buddhist community with a Muslim one. It was not a fear of secession, but rather of the usurpation of the majority community's position at the apex of the power hierarchy in the country.

As for the government's annual commemorations of the military war victory, they serve to demonstrate the apex position of Sinhala Buddhist identity within the power hierarchy of the country. Everything else is to follow from it and everything else is possible only to the extent that this apex position is not disturbed but continues to be enshrined and acknowledged. As Suren Raghavan, a scholar of the politics of Sinhala Buddhism, a former governor of the Northern Province and an SLPP member of parliament points out:

It is a sociological and psychological fact that Sinhalas, especially the Sangha, are looking for a point of pride after three decades of humiliation under a homegrown Tamil-armed rebellion led by a school dropout. The LTTE not only came close to dividing the state, it was nearly successful in permanently dismantling the majoritarian hegemonic mindset of the Sinhala polity. Sinhalas as a regional and global minority take pride in their steadfast resilient to hold Lanka as a Sinhala majority Buddhist state even after some 450 years of harsh European 
colonization. What the LTTE - with its terror politics - tried to change was not merely the unitary nature of Lanka but also the historicized Sinhala Buddhist ethnoreligious national pride. Sangha as direct recipients and beneficiaries in overcoming such ontological insecurities have become the natural champions of a new order that will not only wipe away such shame but also re-establish overarching control. ${ }^{6}$

What the military victory has done, with its dominant Sinhala Buddhist idiom of celebration and commemoration, is to openly challenge and jettison the idea of Sri Lanka as a plural, multi-ethnic and religious society founded on the notion of "unity in diversity". It has now been replaced by the idea of a majoritarian society of Sinhala Buddhist primacy, with all the authoritarian impulses and attitudes that it entails to secure and consolidate this idea.

\section{Notes}

1 Following the war, only in the latter years of the Yahapalanaya (Good Governance) government in power from 2015-19 was the national anthem sung in both official languages, Sinhala and Tamil.

2 The scholarly monk Ven Walpola Rahula wrote with reference to the battle between Sinhala Prince Dutugemunu and the Tamil Chola King Elara: "From this time the patriotism and the religion of the Sinhalese became inseparably linked ... and assumed such overpowering proportions that both bhikkus and layman considered that even killing people in order to liberate the religion and the country was not a heinous crime." (Rahula Walpola 1946 and quoted in Zuhair 2016).

3 The title translates as the Universally Renowned Overlord of the Blessed Three Sinhala Regions - the latter regions being Ruhuna, Pihita and Maya, each of which was ruled by a separate king at the time of the Portuguese invasion in 1505 . The Malwatte and Asgiriya chapters are the two main "chapters" of the Sangha or priesthood. The monasteries of the two main chapters have enjoyed the right, upheld by the British colonial government, to make appointments to the major Budddhist centres in the country.

4 Quoted in the Daily News, on Monday 25 May 2009 and in the Asian Tribune, on Sunday 24 May 2009.

5 Suren Raghavan, "Sri Lanka: Towards a militant Sangha state", 23 November 2013, www.colombotelegraph.com/index.php/sri-lanka-towards-a-militant-sangha -state.

6 Raghavan, Suren. "Sri Lanka: Towards a militant Sangha state". Colombo Telegraph, 23 November 2013, www.colombotelegraph.com/index.php/sri-lanka-towa rds-a-militant-sangha-state.

\section{References}

Adaderana. "Three chapters on President in Mahavamsa: Report". April 6, 2011, www.adaderana.lk/news.php?nid=12692.

Alagiah, George. "Sri Lanka's retreat into language of conspiracy". BBC News Colombo, 15 November 2013, bbc.com/news/world-asia-24951955.

Anketell, Niran. "Hijacked Justice? Truth and reconciliation in Sri Lanka". Open Democracy, 3 December 2013, www.opendemocracy.net. 
Athas, Iqbal. "Sri Lanka president makes conspiracy claims". CNN World, 9 January 2009, edition.cnn.com/2009/WORLD/asiapcf/01/09/sri.lanka.civil.war/index.html.

Balachandran, P.K. "Northern Sri Lankan Governor defends building Buddhist temples”. 18 August 2016, newindianexpress.com/world/2016/aug/18/North-SriLa nkan-Governor-defends-building-Buddhist-temples-1510667.html.

Centre for Policy Alternatives. "A Critique of Promises Made and Present Trends". Colombo, Centre for Policy Alternatives, forthcoming.

Centre for Policy Alternatives. Confronting accountability for hate speech in Sri Lanka: A critique of the legal framework. Colombo, Centre for Policy Alternatives, September 2018.

Centre for Policy Alternatives. "INFOGRAPHICS: Military Presence in the North of Sri Lanka”. Colombo, Centre for Policy Alternatives18 September 2014, www.cpa lanka.org/infographic-military-presence-in-the-north-of-srilanka/.

Centre for Policy Alternatives, "Practical steps to meaningful reconciliation", Colombo, Centre for Policy Alternatives, 17 February 2012, www.cpalanka.org/pra ctical-steps-tomeaningful-reconciliation/.

Centre for Policy Alternatives. Saving Sunil: A study of dangerous speech around Facebook dedicated to Sgt Sunil Rathnayake. Colombo, Centre for Policy Alternatives, October 2015.

De Silva, Roshan Wijeyeratne. "Republican constitutionalism and Sinhalese Buddhist nationalism in Sri Lanka: Toward an ontological account of the Sri Lankan state". The Sri Lankan Republic at 40: Reflections on constitutional history, theory and practice, edited by Asanga Welikala. Colombo, Centre for Policy Alternatives, 2012.

DeVotta, Neil. "Engaging Sinhalese Buddhist majoritarianism and countering religious animus in Sri Lanka: Recommendations for the incoming u.s administration”. The Review of Faith \& International Affairs, vol. 14, no. 2, 2016, pp. 76-85, doi:10.1080/15570274.2016.1184440.

Dissanayake, Uvin. Technocratic Populism and the Pandemic State: Performative Governance in Post-Covid Sri Lanka. Colombo, Centre for Policy Alternatives, November 2020.

Fernando, Jude Lal. "War by other means: Expansion of Sinhala Buddhism into Tamil region in 'post war' Ilam". Buddhism among Tamils in Tamilakam and İlam. Part 3: Extension and Conclusions, edited by Peter Schalk and Astrid van Nahl, Uppsala, Acta Universitatis Upsaliensis, 2013, pp. 175-238.

Fernando, Jude Lal. "Remembering Mu'l'livaaykaal in proper context". 15 May 2017, tamilnet.com/aut.html artid $=38678 \&$ catid $=79$.

Fernando, Ruki. "Celebrating war victory and banning commemoration of dead victims: This is a homegrown and indigeneous reconciliation and freedom in Sri Lanka". Groundviews, 18 June 2010, https://groundviews.org.

Gammanpila, Udaya. "The constitutional form of the First Republic: The Sinhala Buddhist perspective: an interview". The Sri Lankan Republic at 40: Reflections on constitutional history, theory and practice, edited by Asanga Welikala, Colombo, Centre for Policy Alternatives, 2012.

Governeur, Cédric. "An uncomfortable peace in Sri Lanka: The time of triumphalism”. The Sri Lanka Campaign, 17 April 2010, www.srilankacampaign.org/a n-uncomfortable-peace-in-sri-lanka-the-time-of-triumphalism.

Groundviews. "The official report of the LLRC". Groundviews, 16 December 2011, www.groundviews.org. 
Gunasekera, Tisaranee. "Cult and its heretics". Colombo Telegraph, 24 January 2021, www.colombotelegraph.com/index.php/cult-and-its-heretics.

Gunasekara, Tisaranee. "Gotabhaya Rajapaksa and Bala Sena”. Colombo Telegraph, 14 March 2013, www.colombotelegraph.com/index.php/gotabhaya-rajapaksa-and-his-ba lasena.

Human Rights Watch. "Open wounds and mounting dangers: Blocking accountability for grave abuses in Sri Lanka". Human Rights Watch, 1 February 2021, www.ecoi.net/en/file/local/2044618/srilank0221web.pdf.

Hume, Tim. "Fascists' in saffron robes? The rise of Sri Lanka's Buddhist ultranationalists". CCN World, 17 July 2014, https://edition.cnn.com/2014/07/17/ world/asia/sri-lanka-bodu-bala-sena-profile/index.html.

Kent, Lia, "No Space for Memory?: Memorials, Monuments and the Residues of the War in Sri Lanka's North". Arena Quarterly, 29 May 2020, arena.org.au/no-spa ce-for-memory/.

International Crisis Group. "A dangerous sea-change in Sri Lanka”. International Crisis Group, 29 January 2020, crisisgroup.org/asia/southasia/srilanka/dangerousseachange-sri-lanka.

International Crisis Group. Sri Lanka’s Transition to Nowhere. Asia Report No. 286, International Crisis Group, 16 May 2017, https://d2071andvip0wj.cloudfront.net/ 286-sri-lanka-s-transition-to-nowhere.pdf. Accessed 27 February 2021.

Jayasuriya, Ranga. "Cyril Ramaphosa: What's he doing out here in Sri Lanka?". Ceylon Today, Sri Lanka Brief, 16 July 2014, www.srilankabrief.org.

Jayasuriya, Ranga. Sri Lanka Report. Geneva, Office of the High Commissioner of Human Rights, 27 January 2021.

Jayawickreme, Eranda, Nuwan Jayawickreme, and Elsie Miller. "Triumphalism, fear and humiliation: The psychological legacy of Sri Lanka's civil war". Dynamics of Asymmetric Conflict, 2010, vol. 3, no. 3, pp. 208-222, doi:10.1080/17467586.2010.531031.

Peiris, Kamalika. "Sinhala triumphalism". Lankaweb, 10 July 2018, www.lankaweb. com.

Perera, Melani Mkaanel, "Military building Buddhist temples against local wishes in northern Sri Lanka”. 6 September 2015, asianews.it/news-en/Military-buildingBuddhist -temples- against-local-wishes-in-northern-Sri Lanka-34463.html.

Raghavan, Suren. "Sri Lanka: Towards a militant Sangha state". Colombo Telegraph, 23 November 2013, www.colombotelegraph.com/index.php/sri-lanka-towards-a -militant-sangha-state.

Rajapaksa, Gotabaya. "Address to the nation". Colombo, Government of Sri Lanka, 18 November 2020, www.news.lk/news/politics/item/31072-full-text-of-the-addres s-to-the-nation-by-his-excellency-thepresdent-gotabaya-rajapaksa.

Rajapaksa, Mahinda. "Defeating domestic and foreign conspiracies against Sri Lanka". Colombo Telegraph, 28 June 2020, www.colombotelegraph.com/index. $\mathrm{php} /$ defeating-domestic-and-foreign-conspiracies-against-srilanka.

Rajapaksa, Mahinda. "Sri Lanka President defends military role". BBC, www.bbc. com/news/world/south asia-13570810, 22 May 2011.

Schonthal, Benjamin, and Matthew J. Walton. "The new Buddhist nationalisms: Symmetries and specificities in Sri Lanka and Myanmar". Contemporary Buddhism: An Interdisciplinary Journal, 2016, vol 17, no. 1, pp. 81-115, doi:10.1080/ 14639947.2016.1162419.

Schonthal, Benjamin, and Asanga Welikala. "Buddhism and the regulation of religion in the new constitution: Parliamentary debates, present challenges and future 
options". Working Papers on Constitutional Reform No 3, Colombo, Centre for Policy Alternatives, July 2016.

South China Morning Post. "Radical monk seeks alliance with Buddhists in Sri Lanka". South China Morning Post, 30 September 2014, www.scmp.com/news/a sia/article/1604065/radical-myanmar-monk-seeks-alliance-buddhists-sri-lanka.

Srilal, Ranga. "Radical Myanmar monk joins hands with Sri Lankan Buddhists", Reuters, 29 September 2014, www.reuters.com/article/us-sri-lanka-buddhism-mya nmar-idUSKCN0HO0GD20140929.

Walpola, Rahula. The heritage of the Bhikkus: The Buddhist tradition of service. New York, Grove/Atlantic, 1946/2007.

Wickremesinhe, Roshini, and Sanjana Hattotuwa. Voting in hate: A study of hate speech on Facebook surrounding Sri Lanka's parliamentary elections of 2015. Colombo, Centre for Policy Alternatives, March 2016.

Zuhair, Ayesha. Dynamics of Sinhala-Buddhist ethno-nationalism in post-war Sri Lanka". Colombo, Centre for Policy Alternatives, April 2016. 



\section{Part II}

\section{Forgotten issues}





\title{
5 Social justice and the persistence of racialized segregation
}

\author{
Kevin Durrheim and Amy Jo Murray
}

When the heady days of social transformation begin to recede into history, they often leave behind a sense of bitter disappointment over lost opportunities. This has certainly been the case in South Africa. The struggle for change had been informed by cultivated ideals of justice, equality and nonracialism, as expressed in the Freedom Charter of 1955. The process of change was glorious: the liberation movements were unbanned; leaders including Nelson Mandela were released from prison; joyous protests erupted nationwide and democratic elections followed; resulting in the formation of a representative government and the scrapping of apartheid legislation. Thereafter began the gradual process of reshaping the ideology and demography of the economy, the social body, and public and private institutions.

But the post-apartheid reality has continued to be marked by deep injustices, inequalities, violence, racial division and conflict (Tshishonga 2019). The murmuring of discontent is as loud as ever. It is carried through the air via disparate voices of protest: fallist movements, ${ }^{1}$ factionalism, taxi wars, service delivery protests and the resurgent right, to name but a few. The murmuring is also felt in the ground, reverberating through the reality of unemployment, murder, gender-based violence, racist attacks, hate speech, unequal access to health, education and social services, income inequality, xenophobia, and so on. Pain, anger, guilt, shame, desperation, disappointment and insecurity make a toxic brew of post-apartheid affect (Nyamnjoh 2016).

This chapter sets out with the ambition of explanation. What went wrong? South Africans had good leaders, international support, good economic years and a majority who were genuinely committed to change. How was it possible to fail so badly? One avenue of enquiry, we propose, is the way new patterns of segregation emerged from the ruins of apartheid. These took shape from the substance of apartheid. Townships remained poor and black - albeit with newly acquired municipal services in many instances. Mushrooming informal settlements on the urban periphery also remained deeply poor and black, and became increasingly pan-African. The old urban centres, once the high-value real estate of capital and consumption, fell into ruin and decay as the white inhabitants withdrew their persons and

DOI: $10.4324 / 9781003167280-7$ 
investments. At the same time, in the greatest collective investment and expenditure of wealth in the history of the country, new sites of exclusivity were built from the ground up. Exclusive estates and gated communities, shopping malls, wine farms, office parks, and edge cities created new spaces of residence, consumption, labour and leisure. The geography is not a replica of the rigidly partitioned atlas of apartheid (Christopher 2000), but it echoes the major themes. The post-apartheid geography offers many sites and opportunities for inter-racial contact and exchange, but the reality is that segregation persists both in structures and micro-ecologies.

In this chapter we briefly review the literature that shows why intergroup contact can be a powerful vehicle for change, but why this potential is not realized in persistently segregated contexts. We then focus on forms of migration by which patterns of segregation are re-laid in contexts of transformation. Migration and segregation create new spaces of exclusivity with barriers to entry that help to preserve and re-establish (racialized) inequality. They also help to produce a new aspirational and symbolic order that undermines transformative justice.

\section{Contact theory and the problem of segregation}

Social scientists have long touted desegregation as a mechanism of social change. As early as 1903, W.E.B. Du Bois (1903 p. 32) proclaimed that "the problem of the twentieth century is the problem of the color-line". In his haunting account of the colonial "European sector" and "Native sector", Fanon (1961) showed how inequality and a psychology of oppression took shape around spatial segregation. Later, Pettigrew (1979 p. 122) described segregation as a "structural lynchpin" of intergroup relations, which held together prejudiced attitudes, discriminatory practices, norms of exclusion and a slew of economic inequalities. Around the world, forms of segregation based on ethnicity, religion, autochthony and class have evolved together with racial segregation into a global tapestry of "color-lines" that have persisted well into the twenty-first century.

Given the universality of the problem of segregation, it is unsurprising that a substantial body of work within the social sciences has held desegregation as an objective and ideal of transformative justice (Dixon et al. 2017). This work gathered momentum during the civil rights movement in the USA in the 1950s. Social scientists provided evidence to support the legal challenge to school segregation in the US Supreme Court, showing the negative consequences of segregation and potential positive effects of desegregation for challenging racist attitudes (see Clark 1953). The message was clear: transformative justice would only be achieved by desegregation - and the Supreme Court Justices agreed!

A great deal of research over the past 70 years has supported the hypothesis - formulated by Gordon Allport (1954) as the "contact hypothesis" that intergroup contact under optimal conditions (such as equal status 
cooperation) reduces intergroup prejudice (Pettigrew and Tropp 2006; Kende et al. 2018). This work has progressively clarified the underlying mechanisms. Contact is effective in reducing prejudice when it leads to common identification (Gaertner et al. 1996), when it fosters intergroup empathy and reduces anxiety (Pettigrew and Tropp 2008), and when it allows intergroup friendships to develop (Turner et al. 2007). We also now understand that direct contact is not necessary but that indirect contact with ingroup members who have contact with outgroup members (Wright et al. 1997; Zhou et al. 2019), or even imagining contact (Crisp and Turner 2009) with outgroup members, can also have the effect of reducing prejudice. A recent meta-analysis confirms that contact interventions are effective for reducing prejudice in real world settings outside of the lab (Lemmer and Wagner 2015).

However, over the years there have also been persistent nagging concerns, especially for the efficacy of contact interventions in segregated societies and societies in conflict (Dixon et al. 2005; Maoz 2011). First, negative contact appears to be more powerful in promoting prejudice than positive contact is in reducing it (Barlow et al. 2012). Second, although effective in reducing prejudice, positive contact can also have a "sedative effect" undermining the resolve of oppressed groups to engage in collective action and promote change (Cakal et al. 2011; Dixon et al. 2007). This is especially important in contexts like transformed South Africa, where new elites from the former oppressed groups now have full access to racially integrated places and institutions of economic privilege. Third, and most fundamentally, although friendship and positive contact can promote positive change, the problem in many societies is that such contact is hardly ever attained. Even when it is, or when one experiences extended or imagined positive contact, its affects risk being drowned by the negative experiences, stories and threats that proliferate in socially, economically and institutionally conflicted and segregated societies (Bettencourt et al. 2019).

Pettigrew and Hewstone (2017) have advocated for more sophisticated technical and statistical solutions to these problems. They argue that better studies, and multilevel analyses that take into account the effect of contextual factors (e.g. structural, economic and political), will more clearly identify the individual-level effects of contact on prejudice reduction. They believe that such work will show that contact works and is an even more powerful change agent than previously thought. However, this still leaves an open question about how to promote social change in segregated societies. The original impetus of contact research was societal transformation in the pursuit of social justice (Durrheim and Dixon 2018). Taking contextual factors into account when modelling the effect of contact on attitudes is good science but it is not sufficient in itself to address the political, economic, geographic or psychological solutions to the problem of segregation.

With this objective in mind, we will consider how patterns of migration and segregation work to set up broader attitudes and intergroup relations, and when social change sets in motion practices of migration that undermine 
the creation of more social justice. We will use the work of I.D. MacCrone (1933) to demonstrate the importance of migration and to paint a historical background to the South African case. Our main message is that transformative justice (Evans 2016) is not accomplished by prejudice reduction although this would be ideal and contact can help - but by changing patterns of migration which help to constitute the intergroup context.

\section{Migration and race attitudes on the colonial frontier and beyond}

MacCrone (1933) developed a historical and functional analysis of group prejudice that underpinned apartheid. White prejudices fulfilled functions of group preservation in the context they found themselves in as a minority in Africa, and helped them to preserve their unity, identity and economic interests (MacCrone 1933). These attitudes, he argues, had developed in a specific context of intergroup contact between European settlers and African autochthons. When the Dutch arrived to set up a fort and garden in the Cape in 1652, under Dutch law, they were to leave the native people "undisturbed in their liberty and never enslaved" (p. 47). Nonetheless, the contact situation of exploitative trade and land encroachment fostered an attitude of "increasing dislike and contempt" (p. 47). Within 50 years, the local clans had become so impoverished through their interactions with the European settlers that they needed to be "supplied by the Company with cattle to tend on shares" (MacCrone 1957, p. 82).

Later, in a quest for grazing land and independence, the settlement began expanding outward as Europeans migrated into the interior. In the process, a frontier was established. The frontier was less a boundary line than "the outer edge of the wave - the meeting point between savagery and civilization" (Turner, cited in MacCrone 1957, p. 99). It was here that the psychosocial situation of the settler community developed. The frontier was a site of ongoing expansion and disposition that produced an "atmosphere of war" in which race attitudes assumed "extreme or exaggerated forms of expression" (p. 125). The meaning of the racially charged slur "kaffir" was formed in this context to refer to Africans as "savage, subhuman, treacherous, thieving, indolent, merciless" (Arndt 2018, p. 74).

MacCrone argues that this psychosocial situation extended into the twentieth century, carrying along its racist attitudes. Migration shifted from the frontier as economic opportunities were found in towns and cities. As was always the case, colonizers were dependent on the African population for labour, but now the whites who settled in towns and cities attempted to regulate the migration of Africans into and out of cities. This culminated in the "highest stage of white supremacy" (Cell 1982) - the apartheid system (implemented from 1948 at the election of the National Party) - of pass control, forced removals and rigid, universal de jure racial segregation. This situation prompted something of an attitudinal inversion. In contrast to the hostile frontier, apartheid discourse portrayed idyllic images of rural Africa 
and contented Africans, but viewed city life as a contaminating site for Africans, and "dressed natives" as corrupted (Packard 1989).

\section{The post-apartheid case}

With the end of apartheid in 1994, through South Africa's first fully democratic elections, came a process of transformational justice. Discourses of a "Rainbow Nation" were promoted, presenting hopes of all South Africans moving forward and working together to form a new, post-apartheid South Africa where diversity, justice, freedom, equality, unity and inclusion would become celebrated norms. South Africa would be transformed, especially in the arena of social justice which had largely been undermined through apartheid's system of racial segregation and exclusion. Places of work, education, leisure, commerce and residential communities were officially accessible and open to all citizens.

However, the transition from apartheid through free and fair elections, and mechanisms such as the Truth and Reconciliation Commission (TRC), did not lead to social justice. As is discussed by Tim Murithi in Chapter 2 in this volume, while the TRC succeeded in creating a platform for (some of) the victims and perpetrators of apartheid horrors to speak out, it fell short of instituting material changes in the fabric of South Africa's profound social inequalities, divisions and injustices. Its individualistic emphasis on perpetrators and victims, as well as the Commission's commitment to steering narratives towards peace and forgiveness, and away from anger, revenge or outrage (Statman 2000), constrained the TRC from pursuing wider societal reformations and re-imaginings. Today, South Africa remains a deeply segregated, unjust society.

\section{Migration in post-apartheid South Africa}

Although forced segregation is a thing of the past, South Africa continues to maintain informal racialized spaces through patterns of migration that maintain privilege and exclusion. The right to freedom of movement in public spaces after apartheid made it (theoretically) possible for all citizens to migrate to and within urban centres, rapidly changing the racial profile of South Africa's towns and cities. Areas that had once been reserved for the white minority were open to all. Apartheid government mechanisms that had controlled the flow and subjects of migration were dismantled and new flows and subjects emerged. Yet this migration into (previously) white spaces has not always led to integration (Lemanski 2006).

As previously excluded groups entered public spaces, whites began a parallel migration, abandoning business and residential urban centres in favour of suburban enclaves (Ballard 2004; Christopher 2000). These migrations (re) produced patterns of segregation and inequality that were familiar elsewhere, such as Farley's (1978) depiction of the "chocolate city, vanilla suburbs" 


\section{Kevin Durrheim and Amy Jo Murray}

shows. "White flight" and the flight of capital are not uniquely South African phenomena, but they have arisen from the specific context of colonization and apartheid.

Material and institutional walls and violence that had previously kept the constructed black "other" from entering the city limits were removed. But as Africans now migrated into historically whites-only places and institutions, they were confronted with racist attitudes that echoed the frontier. Employing discourses of crime, fear and increased ambiguity and insecurity (Durington 2009; Lemanski 2004), primarily (though not exclusively) white South Africans have established measures to ensure improved safety and security in the midst of perceived and actual urban municipal mismanagement (Ballard and Jones 2015).

Soon these individualized practices produced more extreme forms of collective control through the formation of and migration to gated communities (Ballard and Jones 2015; Durington 2009; Lemanski 2004). Gated communities range from fortified and enclosed pre-existing neighbourhoods with restricted street access through to the development of new residential communities, in the form of eco-estates, golf estates and other lifestyle-themed estates. In South Africa, luxury residential estates are the only residential properties that have increased in value over the past ten years (New World Wealth 2019a), making them very highly sought after among the elite. In fact, only the USA has more residential estates than South Africa (New World Wealth 2019b).

Gated communities are a worldwide phenomenon of middle- to upperclass citizens retreating into enclaves for increased security, improved services and decreased engagement with wider society, especially the urban poor (Blakely and Snyder 1997; Blandy and Lister 2005; Low 2003). Yet these fundamental features of gated communities take on particular meanings in societies that have undergone political and socio-economic transformation, as in the case of post-apartheid South Africa (Hook and Vrdoljak 2002; Lemanski 2004). Indeed, there are concerns that gated communities "effectively recreate the apartheid city and thwart post-apartheid goals of urban integration and inclusion" (Lemanski et al. 2008, p. 135), especially in light of the fact that more that $40 \%$ of South African individuals with a net worth of US \$1 million reside in some form of gated community or lifestyle estate (New World Wealth 2019b). For many wealthy (primarily, but not exclusively, white) South Africans, migration to gated communities is a symbolic and material exercise of control and power in the face of ambiguity and insecurity since the transition from apartheid (Ballard 2004; Hook and Vrdoljak 2002; Lemanski 2004). The privatized regulation of such residences through body corporates has facilitated a system of effective and insular private governance that is perceived to contrast starkly with the municipal (mis)management and politics of the outside world (Ballard and Jones 2014). It also allows members of gated communities to divorce themselves from civic responsibilities and engagement (Hook and Vrdoljak 2002). This leads 
Lemanski et al. (2008, p. 136) to argue that "gating in South Africa is perceived as a means to wield one's own power, as a private property owner, rather than submit to the state, as a citizen".

\section{The new frontier}

Socially, restricting access to gated communities enables "the exclusion of strangers, often racially defined" (Ballard and Jones 2014, p. 297). In addition, "enclaves do not just respond to difference and fear, but actually deepen segregation and reinforce fear by excluding difference and limiting social mixing" (Lemanski 2004, p. 108). This racial and economic migration has reinforced old privilege and exclusion, leading some to label the system of gated communities as "the new apartheid" (Lemanski 2004). Within these walls, the fear of crime, criminal others and outsiders has become even more entrenched in their inhabitants' social imagination. From the outside, those who are excluded view migration behind walls as yet another rejection, another form of distancing. It is a new frontier.

In addition to the migration of people, post-apartheid cities have seen a movement of capital from urban centres that have largely been abandoned by white residents, investment and business. This migration is exemplified by the relocation of the Johannesburg Stock Exchange from downtown Johannesburg to Sandton in 2000. While policies such as Black Economic Empowerment (BEE) have aimed to shift economic power from the minority white elite to the black majority by giving Africans investment and employment opportunities, this policy intervention - much like the TRC - has focused largely on individuals and has not reached its goals. In implementing this policy, the post-apartheid government held a tension between rapid economic growth, which was largely controlled by white financial investment, and economic redistribution through BEE or similar policies (Tangri and Southall 2008). Corporate investment, which was largely driven by white interests and capital, was given more prominence than policies such as BEE - which has been described furthermore as impacting only a few well-connected individuals instead of changing the underlying factors of socio-economic inequality (Tangri and Southall 2008).

This has allowed white privilege to persist in an ostensibly desegregated society. Symbolic and material luxury attached to capital have become bound up with new spaces where the elite live and work: gated communities, office parks and edge cities that are largely self-contained and separate from the perceived disorder of city centres (Beavon 2004; Michel and Scott 2005). The new decentralized urban spaces outside the old urban centre (Garreau 1991) are vividly portrayed by Kitchin's (cited in Michel and Scott 2005, p. 106) description of La Lucia-Umhlanga Ridge (an edge city outside of Durban) as "island(s) of wealth surrounded by a sea of poverty".

While the migration of individuals to spaces that ensure greater safety and security can be viewed as an exercise of free will, "its collective consequences 
produce a divided city, at odds with post-apartheid ideals of unity and equality" (Lemanski et al. 2008, p. 133). Places such as gated communities and edge cities are infused with migrations that lead to racialized segregation, which is highly consequential in a post-apartheid context. These are places where the elite shop and the disempowered serve; where the elite live and the subaltern clean; where the elite buy and own expensive cars and the racialized poor use public transport to commute to and from places of wealth and privilege where they work but do not seem to belong. Poor South Africans migrate daily in and out of these spaces, while the wealthy (usually white) residents retreat further into their enclaves to which they have permanently migrated, behind symbolic and material walls of exclusion and privilege. All of this tends to more deeply segregate a society that is now a mere shadow of what it had hoped to become.

\section{Conclusion}

South Africa's history has been a story of divisions, as social groups have created and contested frontiers that (re)inscribe power, privilege and property. Although this has reproduced segregation - which is often the point of interest for policymakers and researchers - in this chapter we have shifted our focus from segregation to migration, the dynamic process by which South African society and social attitudes have been formed. Segregation is a snapshot of socio-spatial relations at a specific point in time, whereas migration considers the ever-changing push and pull that keeps people moving towards and away from each other. Migration describes a flow of people, and the movement of social groups who act in relation to their social worlds, establishing and maintaining frontiers that allow, restrict and avoid contact.

The latest stage of this migration has (re)produced forms of segregation, exclusion and distance that fly in the face of the founders of South Africa's new democracy. In the current post-Rainbow Nation era, we continue to confront the realities of (racialized) privilege that migration instantiates and that make social justice so elusive. Despite the transitional goals of unity and integration, we continue to migrate away from racialized others as we live and move in ways that echo the colonial and apartheid patterns of our history. As Rainbow Nation dreams become shadows, property laws and constitutional values are continually circumnavigated by elite citizens as the subaltern are left in slum-like conditions.

Any intergroup contact that occurs in South Africa necessarily occurs within the broader assemblage of racialized privilege. Rather than looking to inter-individual contact at specific moments, we have argued that we need to look to histories of inter-group contact, which in the South African context are embedded in a series of migrations. Social change - and social justice depend then on the ability to intervene in the forces that constrain intergroup contact as patterns of daily lived experience. It might only be through radical 
economic reforms that the current flows of migration can be redirected. Investment that is aimed at places and people who have been excluded from social justice so far needs to be seriously considered, as an alternative to investment into capital flows that only shore up more privilege, power and property for racialized elites. The redistribution of capital on a broad scale, not just among individuals but at community and corporate levels, is necessary. If investment continues to focus on creating spaces of increasing luxury, safety and security that only a few elites can enjoy, we risk recreating and reproducing the apartheid era that continues to haunt us. We will essentially become a society that has migrated away from social justice.

\section{Note}

1 Fallist movements are protest and awareness movements calling for the decolonization of education to illuminate the deep roots of white privilege in South Africa. The fallist movements are led by predominantly black students and include protests such as \#RhodesMustFall and \#FeesMustFall (see Lishivha 2019).

\section{References}

Arndt, Jochen S. "What's in a word? Historicising the term 'caffre' in European discourses about Southern Africa between 1500 and 1800". Journal of Southern African Studies, vol. 44, no. 1, 2018, pp. 59-75.

Ballard, Richard. "Assimilation, emigration, semigration, and integration: 'White' peoples' strategies for finding a comfort zone". Under construction: "Race" and identity in South Africa today, edited by Natasha Distiller and Melissa E. Steyn, Sandton, Heinemann, 2004, pp. 51-66.

Ballard, Richard, and Gareth A. Jones. "The sugarcane frontier: Governing the production of gated space in KwaZulu-Natal". Urban governance in post-apartheid cities: Modes of engagement in South Africa's metropoles, edited by Christoph Haferburg and Marie Huchzermeyer, Stuttgart, Borntraeger Science Publishers, 2014, pp. 295-312.

Barlow, Fiona Kate, Stefania Paolini, Anne Pedersen, Matthew J. Hornsey, Helena R. M. Radke, Jake Harwood, Mark Rubin, and Chris G. Sibley. "The contact caveat: Negative contact predicts increased prejudice more than positive contact predicts reduced prejudice". Personality and Social Psychology Bulletin, vol. 38, 2012, pp. 1629-1643.

Beavon, Keith. Johannesburg: The making and shaping of the city. Pretoria, University of South Africa Press, 2004.

Bettencourt, Leonor, John Dixon, and Paula Castro. "Understanding how and why spatial segregation endures: A systematic review of recent research on intergroup relations at a micro-ecological scale". Social Psychological Bulletin, vol. 14, 2019, pp. 1-24.

Blakely, Edward James, and Mary Gail Snyder. Fortress America: Gated communities in the United States. Washington, DC, Brookings Institution Press, 1997.

Blandy, Sarah, and Diane Lister. "Gated communities: (Ne)gating community development?” Housing Studies, vol. 20, no. 2, 2005, pp. 287-301. 
Cakal, Huseyin, Miles Hewstone, Gerhard Schwär, and Anthony Heath. "An investigation of the social identity model of collective action and the 'sedative' effect of intergroup contact among black and white students in South Africa”. British Journal of Social Psychology, vol. 50, 2011, pp. 606-627.

Cell, John Whitson. The highest stage of white supremacy. Cambridge, Cambridge University Press, 1982.

Christopher, A. J. The atlas of changing South Africa. London, Routledge, 2000.

Clark, Kenneth B., "The social scientist as an expert witness in civil rights legislation”. Social Problems, vol. 1, no. 1, 1953, pp. 5-10.

Clarno, Andy. "Rescaling white space in post-apartheid Johannesburg". Antipode, vol. 45, no. 5, 2013, pp. 1190-1212.

Crisp, Richard J., and Rhiannon N. Turner. "Can imagined interactions produce positive perceptions?: Reducing prejudice through simulated social contact". American Psychologist, vol. 64, no. 4, 2009, pp. 231-240.

Dixon, John, Kevin Durrheim, and Colin Tredoux. "Beyond the optimal contact strategy: A reality check for the contact hypothesis". American Psychologist, vol. 60, 2005, pp. 697-711.

Dixon, John, Kevin Durrheim, and Colin Tredoux. "Intergroup contact and attitudes towards the principle and practice of racial equality". Psychological Science, vol. 18, 2007, pp. 867-872.

Dixon, John, Kevin Durrheim, and Manuela Thomae. "The principle-implementation gap in attitudes towards racial inequality (and how to close it)". Advances in Political Psychology, vol. 38, s. 1, 2017, pp. 91-126.

Du Bois, W.E.B. The Souls of Black Folk. Oxford, Oxford University Press, 1903/2007.

Durington, Matthew. "Suburban fear, media and gated communities in Durban, South Africa". Home Cultures, vol. 6, 2009, pp. 71-88.

Durrheim, Kevin, and John Dixon. "Intergroup contact and the struggle for social justice". The Oxford handbook of social justice, edited by Phillip L. Hammack, New York, Oxford, 2018, pp. 367-378.

Evans, Matthew. "Structural violence, socioeconomic rights, and transformative justice". Journal of Human Rights, vol. 15, no. 1, 2016, pp. 1-20, doi:10.1080/ 14754835.2015.1032223.

Fanon, Frantz. The Wretched of the Earth. New York, Grove Press, 1961/2004.

Farley, Reynolds, Howard Schuman, Suzanne Bianchi, Diane Colasanto, and Shirley Hatchett. "'Chocolate city, vanilla suburbs:' Will the trend toward racially separate communities continue?" Social Science Research, vol. 7, no. 4, 1978, pp. 319-344.

Gaertner, S.L., Dovidio, J.F., and Bachman, B.A. "Revising the contact hypothesis: The induction of a common group identity". International Journal of Intercultural Relations, vol. 20, 1996, pp. 271-290.

Garreau, Joel. "Edge city": Life on the new frontier. New York, Doubleday, 1991.

Hook, Derek, and Michele Vrdoljak. "Gated communities, heterotopia and a 'rights' of privilege: A 'heterotopology' of the South African security-park”. Geoforum, vol. 33, no. 2, 2002, pp. 195-219.

Kende, Judit, Karen Phalet, Wim Van den Noortgate, Aycan Kara, and Ronald Fischer. "Equality revisited: A cultural meta-analysis of intergroup contact and prejudice". Social Psychological and Personality Science, vol. 9, no. 8, 2018, pp. 887-895.

Lau, Ursula, Kevin Durrheim, and Lisa S. Young. "Place detachment and the psychology of nonbelonging: Lessons from Diepsloot informal settlement". Changing 
senses of place: Navigating global challenges, edited by Christopher M. Raymond, Daniel R. Williams, Andrés Di Masso, and Timo von Wirth. Cambridge, Cambridge University Press, 2021, pp. 103-115.

Lemanski, Charlotte L. "Desegregation and integration as linked or distinct? Evidence from a previously 'white' suburb in post-apartheid Cape Town". International Journal of Urban and Regional Research, vol. 30, no. 3, 2006, pp. 564-586.

Lemanski, Charlotte L. "A new apartheid? The spatial implications of fear of crime in Cape Town, South Africa". Environment \& Urbanization, vol. 6, no. 2, 2004, pp. 101-111.

Lemanski, Charlotte L., Karina Landman, and Matthew Durington. "Divergent and similar experiences of 'gating' in South Africa: Johannesburg, Durban and Cape Town". Urban Forum, vol. 19, 2008, pp. 133-158.

Lemmer, Gunnar, and Ulrich Wagner. "Can we really reduce ethnic prejudice outside the lab? A meta-analysis of direct and indirect contact interventions". European Journal of Social Psychology, vol. 45, no. 2, 2015, pp. 152-168.

Lishivha, Welcome. "The fallist movement and the changes it has made". The Mail \& Guardian, 3 May 2019, mg.co.za/article/2019-2005-03-00-the-fallist-movement-a nd-the-changes-it-has-made/.

Low, Setha M., Behind the gates: Life, security and the pursuit of happiness in fortress America. London, Routledge, 2003.

MacCrone, I.D. Distribution of group-attitudes towards the native, 1933. Print.

MacCrone, I.D. Race attitudes in South Africa: Historical, experimental, and psychological studies. Johannesburg, Witwatersrand University Press, 1957.

Maoz, Ifat. "Does contact work in protracted asymmetrical conflict? Appraising 20 years and four major models of reconciliation-aimed planned encounters between Israeli Jews and Palestinians". Journal of Peace Research, vol. 48, 2011, pp. 115125.

Michel, D.P. and D. Scott. "The La Lucia-Umhlanga Ridge as an emerging 'edge city". South African Geographical Journal, vol. 87, no. 2, 2005, pp. 104-114.

New World Wealth. AfrAsia Bank South Africa wealth report 2019. Sandton, New World Wealth, 2019a, https://e.issuu.com/embed.html?u=newworldwealth\&d= south_africa_2019.

New World Wealth. 2019 estate ratings: The top residential estates in South Africa. Sandton, New World Wealth, 2019b, https://e.issuu.com/embed.html?u=new worldwealth\&d=estate_ratings_sa_2019.

Nyamnjoh, Francis B. \#RhodesMustFall: Nibbling at resilient colonialism in South Africa. Bamenda, Langaa Research and Publishing Common Initiative Group, 2016.

Packard, Randall M. "The 'healthy reserve' and the 'dressed native': Discourses on black health and the language of legitimation in South Africa". American Ethnologist, vol. 16, no. 4, 1989, pp. 686-703.

Pettigrew, Thomas F. "Racial change and social policy". The ANNALS of the American Academy of Political and Social Science, vol. 441, no. 1, 1979, pp. 114-131.

Pettigrew, Thomas F., and Miles Hewstone. "The single factor fallacy: Implications of missing critical variables from an analysis of intergroup contact theory". Social Issues and Policy Review, vol. 11, no. 1, 2017, pp. 8-37.

Pettigrew, Thomas F., and Linda R. Tropp. "How does intergroup contact reduce prejudice? Meta-analytic tests of three mediators". European Journal of Social Psychology, vol. 38, no. 6, 2008, pp. 922-934. 


\section{Kevin Durrheim and Amy Jo Murray}

Pettigrew, Thomas F., and Linda R. Tropp. "A meta-analytic test of intergroup contact theory". Journal of Personality and Social Psychology, vol. 90, no. 5, 2006, pp. 751-783.

Statman, James M. "Performing the truth: The social-psychological context of TRC narratives". South African Journal of Psychology, vol. 30, 2000, pp. 23-32.

Tangri, Roger, and Roger Southall. "The politics of black economic empowerment in South Africa". Journal of Southern African Studies, vol. 34, no. 3, 2008, pp. 699-716.

Tshishonga, Ndwakhulu. "The legacy of apartheid on democracy and citizenship in post-apartheid South Africa: An inclusionary and exclusionary binary?" AFRIKA Journal of Politics, Economics and Society, vol. 9, no, 1, 2019, pp. 167-191.

Turner, Rhiannon N., Miles Hewstone, Alberto Voci, Stefania Paolini, and Oliver Christ. "Reducing prejudice via direct and extended cross-group friendship". European Review of Social Psychology, vol. 18, no. 1, 2007, pp. 212-255.

Wright, Stephen, Arthur Aron, Tracy McLaughlin-Volpe, and Stacy A. Ropp. "The extended contact effect: Knowledge of cross-group friendships and predjudice". Journal of Personality and Social Psychology, vol. 73, no. 1, 1997, pp. 73-90.

Zhou, Shelly, Elizabeth Page-Gould, Arthur Aron, Anne Moyer, and Miles Hewstone. "The extended contact hypothesis: A meta-analysis on 20 years of research". Personality \& Social Psychology Review, vol. 23, no. 2, 2019, pp. 132-160. 


\title{
6 Intergenerational justice
}

\author{
Esther Surenthiraraj
}

\section{Introduction}

Transitional justice was born as a temporally limited, extraordinary measure of justice that responded to catastrophic events. Over time, it has become applicable to a variety of political conditions (Teitel 2003). In its current manifestation, however, transitional justice still carries some of the aspects that shaped its birth as an extraordinary form of justice that is time- and context-bound. Given the particularity of its interventions, and their limited and limiting temporal relevance, it is unsurprising that transitional justice measures often draw on existing fault lines that remain entrenched in the context within which they operate. This chapter speaks of the direct and implied transitional justice measures prevalent in post-war Sri Lanka.

The three-decade-long civil war that unfolded in Sri Lanka was fought largely between the Sri Lankan armed forces, generally seen as representing the Sinhalese ethnic majority group, and the Liberation Tigers of Tamil Eelam (LTTE), which proclaimed itself the representative of the second largest community in the country, the Tamils. Noting the discriminatory treatment of Tamil citizens, the LTTE waged a guerrilla-type warfare against the state demanding territorial and institutional autonomy for Tamils. Following several attempts at negotiated settlements, the war was finally brought to an end in May 2009 through brutal military action, which left many displaced, disabled, missing or dead. While issues such as gender and class remain embedded in social structures, ethnicity became the overdetermining factor of analysis, especially of the war (see Gunasinghe 1984/1996). Fault lines that became socially entrenched in the context of war took the form of particular ethnic cleavages. War-related issues faced by Muslims, who are classified by their religious identity in a country in which ethnicity takes centre stage, were largely ignored (Haniffa 2007; McGilvray and Raheem 2007). Transitional justice measures largely focused on the two major ethnic groups, Sinhalese and Tamils, often overlooking Muslim communities affected by war (Haniffa 2015).

Communities that emerge during prolonged war are often forgotten during the planning of the transitional justice processes. In long-term, large-scale displacement for example, fresh relations are formed, and existing ones are

DOI: $10.4324 / 9781003167280-8$ 


\section{0}

Esther Surenthiraraj

reshaped, as groups abandon their homes and either continue to journey from place to place or settle in surroundings different to their origins (on diaspora communities see Orjuela 2020; see also Chapter 8 in this volume). The communities that emerge from these relations are often ignored, and even if considered, are accounted for simplistically, erasing the complexity that their social relations contain. All too often, architects of transitional justice measures overlook how different generations experienced the war and how this shapes their post-war demands. Sometimes these demands overlap across generations; at other times they deviate and complicate transitional justice measures that are envisioned superficially with only one generation in mind.

In Sri Lanka, transitional justice has a contentious history, which can be traced to the development of a troubled Sinhala Buddhist public consciousness during and after the late stages of the war (Dewasiri 2020, see also Chapter 4 in this volume). Post-war transitional justice has been marked by a series of actions, including local and international commissions and reports focused on wartime injustices, United Nations resolutions on Sri Lanka (cosponsored by the Lankan government for a short period of time from 2015-19), attempts at amending the Constitution in ways that guarantee non-recurrence of the conflict, alongside post-war development projects, with a focus on urban regeneration and the tourism industry. All these were touted by local and international state and non-state actors as panaceas to post-war recovery. Directly related to transitional justice measures was the establishment of the Office of Missing Persons in 2016 and the Office of Reparations in 2018. These offices, however, are largely symbolic measures. Justice, truth-seeking, accountability, reparations and institutional reform remain distant and obscure to local communities, also because the very terms associated with transitional justice that index particular legal procedures are reinterpreted by both the state and local communities to fit specific imaginations of justice (on reparations see de Mel and Kodikara 2018).

This chapter draws on fieldwork conducted in the Puttalam district, with the Northern Muslims of Sri Lanka, to discuss the complexity of justice measures in post-war settings. The case of the Northern Muslims is embedded in the history of war but also has its particularities. The community emerged during wartime, following the expulsion of Muslims living in the Northern Province. In October 1990, all Muslims living in the northern regions under LTTE control were expelled from the province on LTTE orders, with some being permitted only two hours to vacate their homes (Hasbullah 2001). Being formed into a community through the LTTE, rather than through the aggression of the Sri Lankan state, Northern Muslims trouble the Sinhala-Tamil ethnic binary along which the war is generally articulated and analysed. Following their expulsion, a number of Muslims from the North gravitated towards and settled in Puttalam, a coastal district in the North-Western Province. Many of them continue to reside there. Over time, the identity of displaced families who hailed from different regions and villages in the North became sedimented into a communal Northern Muslim 
marker. As Thiranagama (2011) observes, the eviction order transformed the Muslims of the North into the Northern Muslims. This marker also formed a distinct socio-political identity through which this group's collective demands are articulated. For the Northern Muslims who have lived away from their homes for over 30 years, displacement has become an orientation, "a way of inhabiting the world" (Thiranagama 2011, 129). The prolonged nature of their displacement means that second and third generations have been born into the community. These generations make Northern Muslims' call for justice and redress complex and multidimensional. Thus, the very factors that mark them - a community that was born of the specific event of wartime expulsion, and lives in prolonged displacement with multiple generations often obscure Northern Muslims in transitional justice processes.

Following their expulsion, Northern Muslims were granted assistance by host communities, donor organizations and, to a limited extent, the state. As the Citizen's Commission on the Expulsion of Muslims from the Northern Province by the LTTE in 1990 (2012) reports, the state provided dry rations for this group until late 2010. Under the Unified Assistance Scheme, it facilitated assistance to purchase land and housing on return but also, following an amendment to the scheme in 1995, upon relocation in Puttalam. Later, the state worked alongside a World Bank project that commenced in 2007 to further facilitate housing schemes in Puttalam. Such assistance was generally directly connected to access to state resources through ministerial portfolios held by Muslim politicians. Therefore, the Commission report notes the assistance provided to Northern Muslims alongside the political affiliations of Muslim ministers and their relations with governments in power. Yet, following the end of war in May 2009, as the needs of those affected by the later stages of the war became urgent and pressing, Northern Muslims were forgotten and marginalized as aid recipients (Haniffa 2015).

Where injustice such as expulsion has taken place decades ago, memory becomes a form of validating the demand for rights and, in certain cases, reparations. However, when memory is bound to justice in this way, the transmission of memory onto the next generation can reinforce the duty to remember for the sake of justice. This complicates the articulation of specific needs and aspirations rooted in the complex experiences of new generations. Inspired by Hirsch (2012), in this chapter I refer to generations that did not directly experience expulsion yet live in its shadow as "postgenerations" (p. 4). Such reference does not intend to collapse into one the experiences of all successive generations. Instead it shows that, although postgenerations did not face expulsion as a direct order, the impact of expulsion continues to inscribe itself down the generations. I will also critique the assumed demarcation of postgenerations' views from those of the first generation. For those who experienced expulsion directly, it has become a temporally distant event, overlaid by their everyday life in prolonged displacement. As the difficulty of return confronts both those from first and successive generations, first generations too voice complex perspectives that overlap with those of 
postgenerations. Hence this chapter speaks of justice as inter-generational, as located in the in-between spaces of generations.

Drawing on the concept of postmemory pioneered by Marianne Hirsch, I will reflect on three selected sources of data, gathered during my larger fieldwork between 2014 and 2016 in Puttalam, in and around the area of Palavi, among resident Northern Muslims: (a) an interview with Abdullah (pseudonym), a first-generation Northern Muslim above the age of 60; (b) a four-part focus group discussion (FGD) with mainly women participants from a range of ages, which concluded in the design and implementation of a community-led artwork competition on the expulsion among postgeneration children of school-going age; (c) a FGD with a group of six second-generation Northern Muslim young adults, which explored the idea of home and the option of return to the North. Reflecting on these three sources and participant observation from limited ethnographic work conducted at the field site, this chapter first highlights postgenerations' resistance to the expulsion as their sole dominant postmemory. It then shows that these memories cannot be completely displaced either, as they result in social, political and economic consequences that could limit access to justice. I will argue that postgenerations hold a variety of memories in tension, recognizing the interwoven nature of remembering while resisting singular memories as definitive descriptors of their community. This analysis highlights the complexity that emerges when memory and justice are coupled across generations and sustains the case for a nuanced understanding of how these elements play out in transitional justice processes.

\section{The concept of postmemory}

In her most recent iteration of the concept, Hirsch defines postmemory as follows:

Postmemory describes the relationship that the 'generation after' bears to the personal, collective, and cultural trauma or transformation of those who came before - to events that they 'remember' only by means of the stories, images and behaviors among which they grew up. But these events were transmitted to them so deeply and affectively as to seem to constitute memories in their own right. Postmemory's connection to the past is thus not actually mediated by recall, but by imaginative investment, projection, and creation ... To grow up with such overwhelming inherited memories is to risk having one's own life stories displaced, even evacuated, by our ancestors. It is to be shaped, however indirectly, by traumatic fragments of events that defy narrative reconstruction and exceed comprehension. These events happened in the past, but their effects continue into the present.

(2019, p. 172) 
For Hirsch, postmemory is distinct from the memory that stems from firsthand experiences of trauma. She states that it is important to distinguish between these two forms of memory so as to avoid appropriating experiences of the first generation while not invalidating memory by proxy. Critiques of her conceptualization of "generation" and the theorization of intergenerational transfer of memory confined to family (Çalışkan 2019) urged a revised definition of postmemory. Hirsch thereafter began to distinguish between familial and affiliative postmemory, where the latter is not confined to familial transfer but "can encompass a larger collective in an organic web of transmission" (Hirsch 2019, p. 173). Affiliative postmemory therefore extends the scope and reach of postmemory.

Of importance is not only Hirsch's argument that postmemory can be so powerful that it constitutes memories of one's own, but also the idea that these memories are sustained by "imaginative investment, projection, and creation", which is a deliberate form of remembering. For postgenerations, especially when memory becomes an imperative for justice, memories of previous generations can become a burden they are obliged to bear. Their own hesitancy to remember or carry on certain memories may be marginalized. Postmemory can thus become a duty, which subsumes the complexity of postgenerational experiences in its bid to remember a singular past.

Tied to Hirsch's concept is Hoffman's discussion of loss and its connection to postgenerations. For Hoffman, it is "[t]ransferred loss, more than transferred memory ... [that] children of survivors inherit" (2010, p. 411). She posits that the affective components of experiences - "the imprint of various personal and historical experiences, as these are traced on individual psyches and sensibilities" (pp. 407-8) - are transferred to successive generations. Condensations of loss that are transmitted through survivors' psychological states become, for Hoffman, a second-generation condition. Drawing on Freud, she also argues that, in order to move on from loss, one must first know what was lost. Although second generations do not have an experience of what was lost, dealing with transmitted loss can be all-consuming - which is reminiscent of Hirsch's argument. However, such experiences also hold heuristic and educational potential. For Hoffman, the second generations' condition offers a way forward that does not diminish or disregard loss, but incorporates it into envisioning a transformed (collective) way of life.

\section{Memory as connection and burden}

The expulsion of Muslims from the Northern Province of Sri Lanka by the LTTE was a form of violence against a community. The eviction order implied that Muslims did not belong in the North, in the Tamil nation-state for which the LTTE claimed they fought. Reactions by expelled Muslims to this extreme measure by the LTTE focused on emphasizing their right to return to and live in the North. Over time, these reactions solidified as a need to show binding connections to their origins. Memory - of expulsion, but 
also of harmonious, tolerant lived experiences in the North prior to expulsion - served this purpose. During interviews that I conducted in Puttalam with respondents from the first generation of expelled Muslims, memories of living on the land (the North) animated conversations about the past. Of particular interest is the interview with Abdullah, who was a retired educator and leader in the community. He was resident in Puttalam although he originally hailed from the Mannar District of the Northern Province. Abdullah spoke of some personal experiences, but during most of the interview he adopted the perspective of a spokesperson for the community. Consequently, this interview took the shape of a vehicle for communal memories. Abdullah's use of the word piLLai ("child") in Tamil, to address me or to tag his sentence, gave an added veneer to the transmission of memories, as Abdullah saw in me a younger woman migrant from a different community, a person interested in the histories and experiences of Northern Muslims unlike most youth from the postgenerations he encountered in Puttalam.

In reference to return and postgenerations, Abdullah says:

After '90, it is the children born here [in Puttalam] who are getting married now. Those children have no thought for that village [in Mannar]. They think only of this village, the facilities and opportunities in this village ... I don't also criticize them. But ... we go there [to Mannar] ... our goods are there - our goods are all there, right? Our coconut fields, paddy fields are all in that place. It is people like us [from the first generation] who go and tend to it [property] or look after it ... These children ... they ask "where are you taking us?" As soon as we came here if we asked "shall we go to Kandy?", they say "yes", if we ask "shall we go to Mannar?", they ask "what is there?" ... It [Kandy] has an attraction to those who go there. What attraction does it have for us? Our interest lies in seeing our village, we go to the area of our village as we have our lands and properties, we will see those things. Now my goods, thank God, still remain, it is hereditarily ours. None of my sons are interested in it ... They were married there, have had children here and if our grandson is sitting for the G.C.E. O/L here in the English medium, what interest will he have in it? Is it the village he was born in? No, right! So if Appa [reference here to grandfather] was born there, Appa was born there, that is ... history. That is history ... They are not personally interested, no?

For Abdullah, postgenerations have no vested interest in their origins. Yet he provides a nuanced understanding of the circumstances under which such a lack of interest is displayed. For the first generation, continued ties to the land lie in their memories and assets that remain. For postgenerations, the same memory cannot animate rootedness in the North. When memory serves as a connection to what was left behind, postgenerations struggle to relate their own experiences to the loss experienced by those who precede them, as they themselves have no tangible memory of living in the North. As Hirsch 
argues, memories of the first generation tend to displace one's own memories in postgenerations and replace them with ones that were transferred by the first generation. What we see here, however, is a resistance to such memories, and the acknowledgement of this resistance by the first generation.

If those of the first generation recognize that their memories are burdensome to later generations, why is their renunciation by postgenerations problematic? Often, resistance to postmemory is understood as willful "forgetting": that is, a deliberate displacement of memories from the past. The sections that follow question this simplistic understanding, by bringing into the picture two factors that complicate Northern Muslim postgenerations' resistance to postmemory: they remain socially marked by the experience of previous generations and they hold a transgenerational right to redress. These factors highlight the complex subject positions articulated by respondents when dealing with postmemory and problematize "moving on" as supplanting past memories. They also challenge an understanding of remembering and forgetting as a binary opposition. Engaging with these factors therefore urges a deeper conceptual engagement with justice and memory.

\section{Social markers of trans-generational experiences}

Even if postgenerations may wish to move away from remembering expulsion as a dominant narrative, they remain socially marked by the experiences of their ancestors. This is apparent in interviews with respondents, but also in the four-part FGD that concluded in the community-led intervention of an art competition. In the first of the FGDs, participants discussed whether the intervention should be about remembering the past or "moving on". During this conversation a female participant voiced the following opinion:

We were displaced in '90 and came [here]. We are the refugees. Our children are not refugees ... they resist the "refugee" label. They don't fear as much as we do. Because from their birth certificate onwards, everything is [registered] here.

This participant voices an important tag that continues to haunt postgenerations - ahathi (refugee). Used indiscriminately in Tamil to refer to both the internally displaced and the stateless, this label is complex. On the one hand, it enables a political and humanitarian demand that forces the state to recognize Northern Muslims' right to return (Surenthiraraj and de Mel 2019). On the other hand, it hinders meaningful social integration of the Northern Muslims and their postgenerations who wish to remain in Puttalam into the district's populace (Brun 2003, 2008). In the extract above, the continued use of the word "refugee" to label postgenerations is resisted by a first-generation participant. A similar sentiment was echoed by another woman during the second of the four-part FGDs: 
But from now onwards it should be [our goal] to eliminate that refugee label. It is not an issue for us, but we have children. They are registrants of Puttalam. They didn't come [here] as refugees! They were born in Puttalam, studied and grew up all in Puttalam. When they go somewhere there is no necessity to inquire if they are refugees [or not]! ... Though [those] children are born in Puttalam - when they go somewhere and are asked "where are you from?" those children say "Puttalam". [When they are asked] "then where are your mother and father from?" they say "Mannar", [then they are asked] "then are you a refugee?" The label returns, the refugee label.

Both of these women who resist the social marking of postgenerations as "refugees" are first-generation Northern Muslims. Here we find an acknowledgement by them that the experiences of their descendants are different to their own. Yet in social settings postgenerations carry this weight which places their own experiences in the shadow of those of their predecessors. Second-generation Northern Muslims offered a complementary narrative to the sentiments expressed. In an FGD conducted with a group of six secondgeneration respondents, when the question of home emerged, two women expressed the following thoughts:

E: We are not in the state of mind yet to accept Puttalam as our hometown ... although [I was] born and raised here, I cannot accept this [as my home].

B: But when we are outside [the district], we say [we are from] Puttalam. There is some attachment in saying [we are from] Puttalam. Inside [the district] there are confrontations with Puttalam people.

Second-generation Northern Muslims typically experience oscillation between two locations. For them, postmemory remains strong enough that they still acknowledge the North as their home, in spite of being born and raised in Puttalam. However, they also display a firm attachment to Puttalam, given that their experiences are rooted in this locality. Their experience nuances an outright rejection of postmemory, and offers instead a spectrum of responses that holds multiple memories that are in tension with each other. They refuse a binary reaction to remembering or forgetting the experiences of their predecessors, asking instead for a nuanced process of remembering the distant past while not overlooking the more recent one.

\section{Memory and right to redress}

Returning to the question of resisting postmemories, a second source of complication is that justice in the present remains connected to the past. In this sense, it is important that memories are transmitted and retained actively as pathways to reparations. Redress can be material or symbolic, and 
accessible whether one chooses to return to the North and/or remain in Puttalam. Materially, it can be compensation for loss of assets, and symbolically it can mean belonging and therefore having the right to return.

During the interview with Abdullah he articulates the dilemma of remembering as follows:

Now everyone has put up [settled] here [in Puttalam], has gone to school here, has friends here, has married here. After this it has come to a state where they ask is there such a village [in Mannar], is there such a place. But at the same time we cannot lose the land on which we were born [in the North]! Cannot lose our heritage!

Here, Abdullah formulates a link between remembering and land. Land was a symbol of autonomy in the war between the LTTE and Sri Lanka government armed forces, and the demand for a geographic territory for Tamils became a significant demand of the LTTE. Post-war, it continues to occupy discussions in relation to Sri Lanka's constitutional amendments. Land remains a symbol of belonging and a path to citizenship rights. It is thereby a terrain on which communities' demands for recognition and transitional justice are articulated (see Fonseka and Raheem 2011; People's Alliance for Right to Land 2020).

Land in this context speaks to both material and symbolic belonging. The crux of the argument Abdullah makes is that if memories are not transferred to successive generations, land and all that it entails will be lost to the evicted Northern Muslims. He does not deny that for generations born and raised in Puttalam memories of the North are vague. However, in a system that links justice to the past, the transmission of memories remains crucial to accessing compensation for loss, whether one chooses to return and/or remain. For postgenerations who struggle between maintaining a transferred memory of origins and their own lived memories in Puttalam, such a linking of justice and remembering to achieve redress for past atrocities remains fraught. Their resistance to postmemory thus becomes complicated, as the right to material and symbolic compensation remain tied to actively remembering and emphasizing the event of expulsion.

The decision to return to the North and/or to remain in Puttalam further complicates this link between memory and justice. In the community-led intervention discussed earlier, the tension between choosing to remember the expulsion or not, and how and what to remember exactly, marked the entire process of its planning. In the first of the four-part preparatory FGDs it was suggested that the resulting intervention should involve children. Discussions thereafter circled around how much attention should be given to the event of expulsion itself, and whether it was opening up old wounds that would be transferred to children, who did not experience the event themselves. Parallel to this discussion was the need to recognize the current situation in Puttalam and that the intervention should be future-oriented. The intervention 
eventually became an artwork competition for children. Thematically it married the past to the present, touching on displacement but recognizing the generosity of the host community in the Puttalam district in sharing their resources with the Northerners.

The conversations that took place during the FGDs reveal the tension that exists between remembering the North and focusing on Puttalam. For the group that wishes to remain in Puttalam, the memories of living in there takes precedence over memories of the North. Their views overlap, but also diverge from those who wish to return to the North. According to the general perspective, however, among the postgeneration, the latter seems to be a small minority. For example, in the FGD conducted with second-generation Northern Muslims, of the six participants involved, only one woman expressed a wish to return to the North. For those from postgenerations who wish to return, however, transmission of memories are important facets of access to the North, as these memories support their right to live in this province. They also facilitate their transition and settlement as individuals from postgenerations who choose to return, but who have no personal memories of the North that they can draw upon to support this process. Therefore, their desire to return forms around their parents' memories, helping them to navigate their transition to the North. Return based on memory is not without its problems. Discrimination against Muslims grows on segregated experiences of public life that were present previously. Return is complicated, therefore, not only because of the changed demographics and landscape of the North - which have been transformed significantly due to war, internal displacement and more recent post-war reconstruction - but also because of segregated ethnocentric living patterns (see Thiranagama 2018). However, as postmemory remains tied to the justice of return, Northern Muslim postgenerations are unable to completely discard memories of living in the North. Expulsion, and subsequently living in displacement without abandoning the idea of - and the right to - return, constitute their condition.

\section{Conclusion}

In this chapter, I have discussed the complexity of remembering by focusing on memories transferred to postgenerations of Northern Muslims in Sri Lanka. While the first generation recognizes the resistance of postgenerations to the memory of wartime expulsion and the experiences surrounding this event, such resistance does not simply mean a displacement of the dominant memories of expulsion, as these are linked to justice and access to rights and reparations that stem from the original event. Northern Muslims offer, instead, complex subject positions as a response to the hegemonic influence of this postmemory. They recognize that memories of and around expulsion are part of a network of multiple interlinked memories, which are potentially in tension with each other. In this way, they counter the effects of a dominant memory on expulsion at risk of displacing their own lived experiences. 
In arguing the above, the chapter troubles the coupling of justice with memory in transitional justice processes. The experiences of the Northern Muslims in Sri Lanka pose a challenge to this coupling. For them, access to justice requires that memories be transmitted to the next generation, as these memories are crucial to the demand for redress. However, such transfers can also result in sustaining memories related to expulsion from the North as the dominant form of memory, over-shadowing memories of living in Puttalam. Northern Muslims navigate this dilemma by presenting a complex understanding of, and critical engagement with, remembering. Their responses can inspire scholars and practitioners willing to engage more deeply with the entangled nature of the different pillars of transitional justice and to develop a more holistic approach to how the notions of memory and justice are understood and mobilized in post-war situations.

\section{Acknowledgements}

Fieldwork for this paper was funded by the Pluralistic Memories Project, which was supported by the Swiss National Science Foundation ( $\mathrm{r} 4 \mathrm{~d}$ - Swiss Programme for Research on Global Issues for Development, Project Pluralistic Memories, SNSF grant number: 400240_146955 / 400240_171188).

\section{References}

Brun, Cathrine. Finding a place: Local integration and protracted displacement in Sri Lanka. Social Scientists' Association, 2008.

Brun, Cathrine. "Local citizens or internally displaced persons? Dilemmas of longterm displacement in Sri Lanka". Journal of Refugee Studies, vol. 16, no. 4, Dec. 2003, pp. 376-397, doi:10.1093/jrs/16.4.376.

Çalışkan, Dilara. "Queer postmemory”. European Journal of Women's Studies, vol. 26, no. 3, Aug. 2019, pp. 261-273, doi:10.1177/1350506819860164.

Citizen's Commission on the Expulsion of Muslims from the Northern Province by the LTTE in October. 1990. The quest for redemption: The story of the northern Muslims. Law \& Society Trust, 2012.

de Mel, Neloufer, and Chulani Kodikara. "The limits of 'doing' justice: Compensation as reparation in post-war Sri Lanka". Violence and the Quest for Justice in South Asia, edited by Deepak Mehta and Rahul Roy, SAGE, 2018, pp. 39-73.

Dewasiri, Nirmal Ranjith. "Historical consciousness and transitional justice in postwar Sri Lanka". International Public History, vol. 3, no. 2, 2020, doi:10.1515/iph2020-2013.

Fonseka, Bhavani, and Mirak Raheem. Land issues in the Northern Province: Postwar politics, policy and practices. Centre for Policy Alternatives, 2011.

Gunasinghe, Newton. "May Day after the July Holocaust". Newton Gunasinghe: Selected essays, edited by Sasanka Perera, Social Scientists' Association, 1984/ 1996.

Haniffa, Farzana. "Competing for victim status: Northern Muslims and the ironies of Sri Lanka's post-war transition”. Stability: International Journal of Security and Development, vol. 4, no. 1, 2015, doi:10.5334/sta.fj. 


\section{Esther Surenthiraraj}

Haniffa, Farzana. "Muslims in Sri Lanka's ethnic conflict”. ISIM Review, vol. 19, 2007, pp. 52-53.

Hasbullah, Shahul H. Muslim refugees: The forgotten people in Sri Lanka's ethnic conflict. Research and Action Forum for Social Development, 2001.

Hirsch, Marianne. "Connective arts of postmemory". Analecta Politica, vol. 9, no. 16, 2019, pp. 171-176, doi:10.18566/apolit.v9n16.a09.

Hirsch, Marianne. The generation of postmemory: Writing and visual culture after the Holocaust. Columbia University Press, 2012.

Hoffman, Eva. "The long afterlife of loss". Memory: Histories, theories, debates, edited by Susannah Radstone and Bill Schwarz, Fordham University Press, 2010, pp. 406-415, doi:10.2307/j.ctt1c999bq.31.

McGilvray, Dennis B., and Mirak Raheem. Muslim perspectives on the Sri Lankan conflict. East-West Center Washington, 2007.

Orjuela, Camilla. "Passing on the torch of memory: Transitional justice and the transfer of diaspora identity across generations". International Journal of Transitional Justice, vol. 14, no. 2, 2020, pp. 360-380, doi:10.1093/ijtj/ijaa005.

People's Alliance for Right to Land, "Our Land, Our Life": People's Land Commission Report. People's Alliance for Right to Land, 2020.

Surenthiraraj, Esther, and Neloufer de Mel. "Two homes, refugees in both': Contesting frameworks - the case of the northern Muslims of Sri Lanka". Journal of Social and Political Psychology, vol. 7, no. 2, Dec. 2019, pp. 1044-1064, doi:10.5964/jspp.v7i2.850.

Teitel, Ruti G. "Transitional justice genealogy". Harvard Human Rights Journal, vol. 16, 2003, p. 69-94.

Thiranagama, Sharika. "The civility of strangers? Caste, ethnicity, and living together in postwar Jaffna, Sri Lanka”. Anthropological Theory, vol. 18, no. 2-3, 2018, pp. 357-381, https://doi.org/10.1177/1463499617744476.

Thiranagama, Sharika. In my mother's house: Civil war in Sri Lanka. University of Pennsylvania Press, 2011. 


\title{
7 Non-citizens' rights \\ Xenophobia, nationalism and struggle post-transition
}

\author{
Philippa Kerr and John Dixon
}

\section{Introduction}

A negative moment is one where new antagonisms emerge while old ones remain unresolved.

(Mbembe 2015)

Transitional justice often involves erstwhile victims of unjust regimes taking over political power from their former persecutors. At the end of apartheid in South Africa, this transition happened in a "negotiated revolution" when members of the banned African National Congress (ANC) began to meet in secret with members of the National Party in the late 1980s. The eventual outcome of these negotiations was the unbanning of the ANC and other political parties in 1990, the release of Nelson Mandela and other political prisoners, the adoption of an interim Constitution, and, eventually, the first democratic elections in 1994, which ushered in an ANC government (Jung and Shapiro 1995).

But, in the years that followed, South Africa had to address the question of how to "deal with the unfinished business of the past" (O'Connell 2018, p. 33). This is perhaps the classic transitional justice question. Most studies of transitional justice practices in South Africa have tended to focus on the work and aftermath of the Truth and Reconciliation Commission (TRC) which operated between 1996 and 1998 (e.g. van Zyl 1999; Mamdani 2002; Gready 2011). The TRC's mandate was to hear and record the testimonies of people who had been victims of gross human rights violations during apartheid, specifically in the period between 1960 and 1994. Perpetrators of these crimes could also apply to the TRC for amnesty, in exchange for telling the whole truth, in public hearings, of what they had done, and if they could establish that the crimes had been politically motivated.

While the TRC process enabled many ugly truths, especially of the late apartheid years, to come to light, criticisms were levelled at the TRC by victims and their families who believed that the emphasis on truth and amnesty essentially avoided justice (cf. Mamdani 2002). Others have criticized the TRC's limited ability to address the broader structural violence that black

DOI: $10.4324 / 9781003167280-9$ 
South Africans who suffered under the old regime continue to suffer in the new dispensation (Gready and Robins 2014; Evans 2016; cf. Madlingozi 2017). Between 1995 and 2014, under the ANC government, unemployment in South Africa rose from $15 \%$ to $27 \%$ (using a conservative definition of unemployment; a more expansive one puts the figure in the high 30s) (Jonas 2018). This burden of unemployment is borne highly disproportionately by black people. Madlingozi (2017) has argued that South Africa is in a time of "neo-apartheid constitutionalism", a term which is used intentionally to "call attention to the fact that post-1994 constitutional re-arrangements are transforming society in ways that do not instantiate a fundamental rupture with [apartheid]" (p. 125). Continuing residential racial segregation, a skewed distribution of wealth in favour of white South Africans, coupled with deteriorating health and education systems and systemic corruption in government and state-owned enterprises means that the post-apartheid period has not been a prosperous one for most black communities.

The purpose of this chapter is not to examine the TRC or other specific transitional justice mechanisms in South Africa in detail, nor is it to offer a critique of the lack of transformative justice and substantive socio-economic redress in the TRC's aftermath - others have already ably done this (e.g. Gready and Robins 2014; Evans 2016; see also Chapters 2 and 5 in this volume). Rather, it is to draw attention to a new form of collective violence that emerged after apartheid - the phenomenon of anti-immigrant violence and to raise questions about how this violence is legitimated in the democratic human rights era. At around the same time as the TRC was concluding its work and submitting its final report, the first academic studies started to appear on a new form of violence and discrimination against mainly African, and to some extent Asian, immigrants, which they named xenophobia (e.g. Crush 2000; Harris 2002; Vale 2002; for an account of the emergence of this term in the media, see Palmary 2016). In May 2008, xenophobic violence exploded around the country, with attacks on foreign communities beginning in Alexandra township in Johannesburg and spreading rapidly to other cities. This violence left at least 62 deaths in its wake, and displaced up to 100,000 people, many into temporary camps for internally displaced persons (Landau 2011). Perhaps the most infamous image to circulate in the media was of a Mozambican man, Ernesto Nhamuave, burning to death after being set alight by South African attackers. The case for Nhamuave's murder was closed without identifying any suspects and no one was ever arrested (Tromp 2015), but Nhamuave is not the only foreign national to have been killed by burning (Misago 2016).

These attacks "provided a forceful contrast to the work of reconciliation that had taken place just a decade earlier, work that was central to articulating a human rights framework for post-apartheid South Africa" (Solomon 2019 , p. 156). By 2010, there were still very few successful convictions for the 62 alleged murders and hundreds of other crimes committed during May 2008 (South Africa Human Rights Commission, cited in Breen and Nel 
2011 , p. 41). In 2015, there was another spike in anti-immigrant violence that led to at least ten deaths. It is likely that these attacks were provoked by the Zulu monarch, King Goodwill Zwelithini, who made a notorious speech at a "moral regeneration" event during which he compared immigrants to lice and called on them to "pack their bags and go back where they came from" (Zwelithini 2015). In fact, xenophobic violence is chronic and ongoing, and every year after May 2008 there have been at least as many murders of foreign nationals as there were in that month (Landau 2015; Misago 2016). In general, the government response to xenophobic violence has been weak and denialist, with many politicians claiming that these incidents are "merely crime" and not "xenophobia" (Crush and Ramachandran 2014; Misago 2016). Also, until very recently South Africa lacked specific hate-crime legislation, making it difficult for the police and criminal justice system to identify xenophobic motives (Breen and Nel 2011; Breen et al. 2016).

But 2015 was also a year that saw many black university students calling for decolonization and the end of white privilege in South African universities under the banner of \#RhodesMustFall and other related student movements. Black students and academics calling for decolonization - in some cases, supported by white peers and colleagues - argued that universities continued to be colonial in their character and curricula (Heleta 2016); that the state "transformation" programme had evidently failed to undo the anti-black structure not only of universities, but also of the economy and society; and that more radical decolonization was now needed instead (Naidoo 2015; Madlingozi 2017; cf. Mbembe 2015). Black pain, black rage and the unacceptability of black poverty were some of the defining tropes of the decolonization discourse, illustrated powerfully when Chumani Maxwele threw a container of human faeces, collected from bucket toilets in poverty-stricken shanty towns around Cape Town, onto the statue of Cecil John Rhodes at the University of Cape Town (UCT). Rhodes was a British empire builder in 19th-century Southern Africa, a diamond mining magnate and governor of the Cape Colony between 1890 and 1896. UCT is built on land he owned and bequeathed in his will to the public of South Africa. In these and other protests, students expressed anger that not only the statue of Rhodes, in its prominent position at UCT, but numerous other statues and memorials on university campuses also glorified racist white politicians and educators.

\section{New antagonisms}

And so it was that in 2015, a year of both calls for decolonization and of anti-immigrant attacks, philosopher and political theorist Achille Mbembe observed that South Africa had entered a "negative moment", where "new antagonisms emerge while old ones remain unresolved" (2015). Mbembe, who is affiliated with the University of the Witwatersrand in Johannesburg and was involved in negotiations with students during protests there in 2015- 
16 (Habib 2018), is himself originally from Cameroon. He went on to elaborate:

Today many want to finally bring white supremacy to its knees. But the same seem to go missing when it comes to publically [sic] condemning the extra-judicial executions of fellow Africans on the streets of our cities and in our townships. As Fanon intimated, they see no contradiction between wanting to topple white supremacy and being anti-racist while succumbing to the sirens of isolationism and national-chauvinism.

(Mbembe 2015)

One of the authors of this chapter (Kerr) witnessed this contradiction at UCT while teaching there temporarily in 2016. Students continuing the momentum of the 2015 protests called for free decolonized education and attempted to shut down the university and prevent the completion of the academic year in order to force the institution to capitulate to their demands. These protests featured mass meetings with a well-known speaker and an audience of students and staff. At one such meeting that I attended, an academic who was a supporter of the student movement and an outspoken proponent of decolonization stood up to speak. Although I no longer remember the details of his whole speech, it ended by singling out the foreign African security guards employed by the private security company which the university had, controversially, contracted to protect the university buildings and enable the continuation of the academic programme. Not a single person spoke up or called out in the meeting that this was xenophobia. Almost the whole meeting then left the hall, apparently to go and confront the foreign security guards. It took me some time to fully realize that what had just happened was an example of an incitement to anti-immigrant violence at a public meeting, couched in the language of legitimate struggle which I had by then read and heard so much about in my own studies on xenophobia. No one asked what purpose would be served by attacking the lowliest employees of the security company, rather than, for instance, confronting the university administrators responsible for contracting it.

This chapter is about that "new antagonism" - the phenomenon of antiimmigrant or xenophobic violence - which emerged after apartheid while the "old antagonism" of racial inequality among South African citizens was still unresolved. It presents a conundrum to the transitional justice paradigm: how can we understand new forms of post-transition violence and victimization which are not simply a straightforward continuation of the violence of the old era, but in fact draw on some of the languages and practices of liberation struggle and transitional justice? Indeed, we will argue that the cooccurrence of these two imperatives in contemporary South Africa - the imperative to transform or decolonize institutions of white privilege and the imperative to rid the country of "foreigners" - is not simply incidental. Rather, anti-immigrant discourses draw deeply on ideologies of struggle, 
rights, freedom, and even community healing and reconciliation (e.g. Palmary 2016; Solomon 2019; Kerr et al. 2019; Monson 2015), while, in the process, taking the nationalist assumption of citizens' entitlements more or less for granted. In the next section, we first discuss Neocosmos's historical account of the roots of xenophobia in the transition to democracy, and then draw on a diverse set of qualitative case studies which have analysed the views of perpetrators and apologists of xenophobic violence, mainly expressed in research interviews and focus groups at a number of locations around South Africa. Thus, the chapter will show how the very discourse of transitional justice can be co-opted to legitimate new forms of violence against people who have little to do with the actual history of apartheid but are accused of undermining South Africans' ongoing efforts to realize the material benefits of liberation in the present.

\section{The roots of xenophobic violence}

What are the roots of this anti-immigrant discrimination and violence in democratic South Africa? Some academics, especially those that note its racialized character, have argued that xenophobia is a manifestation of internalized racism (e.g. Tafira 2011). Other commentators - even those who condemn anti-immigrant violence - nevertheless treat it as axiomatic that economic difficulties, state corruption and chronic poverty make people angry and frustrated, and that in some way it is therefore "understandable" that citizens would turn on their immigrant neighbours (e.g. Zulu 2020, p. 26). But Neocosmos $(2006,2008)$ argues that these reasons are insufficient to explain why this violence is directed at non-citizens and immigrants specifically. Why do poor South Africans blame immigrants for their troubles rather than politicians, or the rich, or corporations, for example? In other words, while xenophobia can and does have racial, ethnic and class overtones (Chauke 2020), the specifically nationalistic element of anti-immigrant violence is often treated as invisible, with commentators falling back more easily onto familiar race- and poverty-based explanations. Neocosmos is one of the few scholars who has offered a historical explanation of the roots of xenophobia, an analysis which requires us to consider how citizens - not only races and classes - were produced in the transition to democracy. He reminds us that during apartheid the distinction between black people who were citizens of South Africa and those who were not was not as strong as it is today. Full citizenship of South Africa was for whites only, and the white apartheid state tried to "denationalize" all black people anyway by dividing them on the basis of ethnicity and then making them citizens of the nominally independent homelands. Thus, black people in South Africa were treated much the same as Africans from further afield: as foreign migrants, who should migrate into "white South Africa" only when their labour was needed. In response, the ideology of the ANC and the anti-apartheid movement was more Pan-Africanist and "was very much conceived ... as a fight of all 
Africans and their allies against the apartheid state. The concept of 'nation' thus developed tended to be inclusive rather than exclusive of Africans from the region" (Neocosmos 2006, pp. 30-1).

So, xenophobia was not an inevitable outcome for the new South Africa. But when the ANC came to power, it chose to treat its population as passive "subjects of state or white largesse", rather than as active subjects able to contribute to their own development (Neocosmos 2006, p. 77). A distinction therefore needed to be made between those living in South Africa who qualified for state assistance and those who did not. The dividing line for this distinction was South African citizenship. Thus, a new category of denationalized outsiders - those who were citizens of other countries and were not considered as eligible for South African citizenship ${ }^{1}$ - was created among those living within South Africa's borders. And the new South African state simply inherited many of the security ideologies and techniques of the apartheid state, so that once again the movement of people into South Africa was conceptualized as a threat to national security, which justified a powerful military (Vale 2002). So, the transition became "a transition between two different forms of xenophobia, simultaneously with continuity between state practises" (Neocosmos 2006, p. vi).

\section{Xenophobia and citizens' rights}

How do South African citizens themselves articulate anti-immigrant or nationalistic sentiments? Solomon (2019) argues that "[p]art of the reason for the persistence of anti-African migrant sentiment is a prevailing rhetoric of victimization, which frames irregular African migrants as a threat to the rights of South Africa's poor" (p. 156). Solomon conducted a number of interviews with residents in areas where violence took place in 2008, including in Alexandra township in Johannesburg where some of the earliest attacks in that spate occurred. He reports:

In asking about the scope of the human rights that should be offered to African migrants in the Alex focus groups, I was declaratively told that 'there are no rights for foreigners' in South Africa, that this 'was not their space,' and that 'only South Africans must have rights' in their country.

Moreover, Solomon argues, many South Africans see "foreigners" as taking opportunities that should rightfully belong to citizens (economic opportunities, government housing, etc.), and are thus "effectively stealing a portion of locals' freedom" (p. 162). He concludes that "these comments show how easy it is to seek to protect the rights of marginalized citizens by stripping even further marginalized noncitizens of their basic rights" (p. 164). 
Solomon (2019) grapples with how hard it is to challenge the spurious connection between the erosion of citizens' rights and the presence of migrants. This is because

Black South Africans have experienced generations of being deprived of rights in their own country, they fought and struggled for decades to gain access to those rights, and now their continued marginalization has left them feeling like that struggle has been in vain. Even worse, outsiders seem to be succeeding in ways that locals have not. In sum, they feel displaced in their own country, which has left some to wonder whether it was a bad decision to open up immigration to the rest of the continent.

(pp. 162-3)

However, there are alternatives: as few other organizations of economically poor South Africans have done, the shack dwellers' movement Abahlali baseMjondolo has argued that migrants are not the cause of South Africans' poverty and that removing them, depriving them of rights or taking other similar drastic measures does not bring about its end. Moreover, the shack dwellers' movement practises an alternative politics of solidarity which emphasizes the de facto shared rightlessness of both migrants and citizens who are black, poor, landless and treated as illegal in various ways by the state (Solomon 2019; Abahali baseMjondolo 2015).

\section{Xenophobia and transitional justice language}

Palmary (2016) examines the discourse of members of South African business owners' associations who organized attacks on immigrant communities in Johannesburg in 2011 and 2015 - in particular those immigrants running small businesses which competed with those owned by South Africans. Palmary notes the deep irony in the way that "the political transition that South Africa has undergone is used as a justification for excluding foreigners in the name of realizing freedom" (p. 79). Once again, business association members invoked the language of rights and of democratic transition to argue for why foreign communities should be made to leave the country. For example, some members of the Greater Gauteng Business Forum (GGBF) said:

We are not saying people mustn't have their freedom but we are talking illegal migrants, we are talking about people who are not even allowed to have that freedom of movement. The migration department [sic] once told them that to say your rights are very limited despite that South Africa has got freedom, that freedom is not yours, it is a South African freedom (GGBF representative, 2011, interview).

(Palmary 2016, p. 96) 
[W]e had to battle for so many years against Apartheid. Now we defeated that part and now we are in the process of rebuilding the country to trust each other, to get to know each other, to tolerate each other, to live with each other, to get to trust each other ... So ... we want us to heal and without any disturbances from them (GGBF representative, 2011).

(pp. 96-7)

In these formulations, it is the very language and concepts of transitional justice that are being deployed to justify anti-immigrant violence.

\section{Xenophobic violence and labour struggles}

Our own work on xenophobia has focused on one particular commercial fruit farming community in South Africa's Western Cape province (Kerr and Durrheim 2013; Kerr et al. 2017, 2019). In 2009, 18 months after the May 2008 violence, South Africans living in the informal settlements around the small town of De Doorns forcibly evicted a community of Zimbabwean migrant farm workers, accusing them of taking their jobs by working for farmers at less than the minimum wage. The Zimbabweans - who left their homes and moved into a temporary camp for displaced persons where they stayed for up to a year afterwards - denied this allegation, and argued, as did the farmers, that they were preferred as workers simply because they were more reliable and hardworking. In this research, we found that among the South African farm worker community, the language and practices of struggle against exploitation from farm owners was almost indistinguishable from those of xenophobia. Indeed, forcibly expelling the Zimbabwean community was construed as a way of ensuring that farmers would not be able to bypass the more stringent bargaining efforts of South African workers and labour brokers (labour brokers are middle-men who supply farmers with workers, and often come from the same communities as those workers). For many of these residents, the white farming community was deeply implicated in the town's problems, as they occupied a position of power to allocate jobs to some workers and not others. When asked why the Zimbabweans had been evicted, one labour broker we interviewed explained:

I also feel very sorry for the people from Zimbabwe who now have to live there [in the displaced persons' camp], uh, and the reason why it happened, uh, is because they never stood with us ... if we as South Africans have problems here in, in De Doorns, then they never stood with us. So, that's why the community decided, there must be further steps taken.

When asked about what kinds of problems the community had experienced in the past, he replied: 
Like I say, we are farm workers here in De Doorns, we all agree whenever prices [wages] need to be raised. Well, true, the state also raises its prices. But ... at the end of the day if we go there, then they won't stand together with us farm workers, when we go to the farms and go talk to the people to hear whether they can't give us a raise.

In this form of victim-blaming, as in many other opinions we heard in De Doorns, justifications for evicting the Zimbabweans were inextricable from claims to be engaged in a struggle with farmers against their exploitative labour practices (Kerr and Durrheim 2013). Other South African workers felt aggrieved that by giving Zimbabweans work these farmers appeared to have no sense of responsibility to their fellow South Africans, with whom they had shared a long and exploitative history; and they also felt aggrieved about having themselves been evicted from their homes on farms in a relatively recent process of farmers "externalizing" large parts of their labour force. For example, one man living in the informal settlement of Stofland remarked: "The white people chased us off the farms so that we are now sitting in squatter camps ... and now they want to put other people from other countries in our place". In this view, the arrival of the Zimbabweans and the farmers' apparent shift of favour to them as a new workforce was just the last straw in a much longer history of exploitative relations between South African workers and farmers in this community. This history was used and invoked in incitements to anti-immigrant violence by workers, labour brokers and local politicians (cf. Misago 2009).

\section{Discussion and conclusion}

The examples discussed in this chapter have shown how a new form of nationalistic identity-based discrimination and violence in post-transition South Africa, that of xenophobia, is justified and legitimated using the language of struggle, rights, victimhood and the realization of South Africans' freedom. While some elements of xenophobia draw on discourses, practices and politics of migration which have their roots in the old South Africa, the specific way that nationalism in post-apartheid South Africa has been configured is what makes this form of violence new. While the overt focus of identity politics discourse in South Africa continues to be mainly on race and racism, anti-immigrant violence is ongoing in the meantime, and there is arguably too little focus on constructions and meanings of South African citizenship as an identity category that warrants critical analysis. In this way, nationalism has come to be not a forgotten issue, but perhaps an invisible one in post-transition South Africa. The structures of transitional justice are hard-pressed to deal with this new violence, because they are attuned to a previous conflict with a different configuration of (racial) victims and perpetrators. Yet xenophobia shows that perpetrators and victims are not mutually 
exclusive categories (Chauke 2020). In this way, questions of race, redress and citizenship in post-apartheid South Africa cannot easily be separated.

Part of the reason for, or perhaps a manifestation of, the pervasiveness of xenophobia in South Africa is that our society lacks a sufficiently compelling or plausible counter-narrative and counter-politics with which to challenge this seemingly axiomatic link between the rights of black South Africans struggling for real liberation and the necessity of removing "foreigners" who undermine that struggle. Xenophobia discourse silences critiques of itself when it legitimates anti-immigrant violence as part of an ongoing struggle, because this sets up a false dichotomy where those proposing an anti-xenophobic politics must also avoid appearing as anti-struggle (Kerr and Durrheim 2013; Kerr et al. 2019). Solomon recognizes this when he claims that "The challenge then is to respond effectively to that rhetoric of victimization and the logic of exclusive rights that underlies it" (2019, p. 164, emphasis added). Claiming that xenophobia implicates the discourses of struggle and rights is not to say that all forms of struggle are xenophobic. There have been cases of successful anti-xenophobic counter-mobilizations and interventions by communities, as well as principled anti-xenophobic or inclusive struggle (see Sinwell 2011; Kirshner 2012; Abahlali baseMjondolo 2015; Solomon 2019). While these are evidently not widespread enough to prevent antiimmigrant violence from becoming a chronic and entrenched crisis (Landau 2015; Misago 2016), they provide some important examples of what an antixenophobic politics looks like in practice. Nevertheless, xenophobia in South Africa shows how the struggles of the poor, including the victims of the legacy of apartheid, can take a toxic or destructive turn when the historic moral legitimacy of these struggles is used to justify further violence against new victimized groups and to silence any critique of this violence. So, a complex dual task now confronts South Africa: of addressing both ongoing racialized inequality among South Africans, and figuring out rhetorical, political and practical alternatives to the construction of (false) mutual exclusivity that is routinely set up between the rights and freedom of citizens and the rights and freedom of migrants.

\section{Note}

1 See Neocosmos (2006) for a discussion of how, after 1994, the possibility was negotiated of extending South African citizenship to migrant miners from Lesotho who had spent much of their working lives in South African mines during apartheid.

\section{References}

Abahlali baseMjondolo. Abahlali base Mjondolo statement on the ongoing xenophobic attacks, 14 April 2015, http://abahlali.org/node/14685/. Accessed 29 March 2019.

Breen, Duncan, Ingrid Lynch, Juan Nel, and Iole Matthews. "Hate crimes in transitional societies: The case of South Africa". The globalization of hate: 
Internationalising hate crime?, edited by Jennifer Schweppe and Mark A. Walters, Oxford, Oxford University Press, 2016, pp. 126-141.

Breen, Duncan, and Juan Nel. "South Africa: A home for all? The need for hate crime legislation". South African Crime Quarterly, vol. 38, 2011, pp. 33-43.

Chauke, Paballo. "Miss South Africa win has tribalism rearing its ugly head". Thought Leader, 30 October 2020, https://thoughtleader.co.za/admin-2/2020/10/ 30/miss-south-africa-win-has-tribalism-rearing-its-ugly-head/, Accessed 2 December 2020.

Crush, Jonathan. "The dark side of democracy: Migration, xenophobia and human rights in South Africa". International Migration, vol. 38, no. 6, 2000, pp. 103-133.

Crush, Jonathan, and Sujata Ramachandran. Xenophobic violence in South Africa: Denialism, minimalism, realism. Migration Policy Series No. 66. Cape Town, SAMP and IMRC, 2014.

Evans, Matthew. "Structural violence, socioeconomic rights, and transformative justice". Journal of Human Rights, vol. 15, no. 1, 2016, pp. 1-20, doi:10.1080/ 14754835.2015.1032223.

Gready, Paul. The era of transitional justice: The aftermath of the Truth and Reconciliation Commission in South Africa and beyond. Abingdon, Routledge, 2011.

Gready, Paul, and Simon Robins. "From transitional to transformative justice: A new agenda for practice". International Journal of Transitional Justice, vol. 8, 2014, pp. 339-361, doi:10.1093/ijtj/iju013.

Habib, Adam. Rebels and rage: Reflections on \#FeesMustFall. Johannesburg, Jonathan Ball Publishers, 2019.

Harris, Bronwyn. "Xenophobia: A new pathology for a new South Africa?". Psychopathology and Social Prejudice, edited by Derek Hook and Gillian Eagle, Cape Town, UCT Press, 2002, pp. 169-184.

Heleta, Savo. "Decolonization of higher education: Dismantling epistemic violence and Eurocentrism in South Africa". Transformation in Higher Education, vol. 1, no. 1, 2016, pp. 1-8, doi:10.4102/the.v1i1.9.

Jonas, Mcebisi. After Dawn: Hope After State Capture. Johannesburg, Pan Macmillan, 2019.

Jung, Courtney, and Ian Shapiro. "South Africa's negotiated transition: Democracy, opposition and the new constitutional order". Politics and Society, vol. 3, no. 23, 1995, pp. 269-308.

Kerr, Philippa, Kevin Durrheim, and John Dixon. "Beyond the two-group paradigm in studies of intergroup contact, conflict and inequality: Third parties and intergroup alliances in xenophobic violence in South Africa". British Journal of Social Psychology, vol. 56, 2017, pp. 47-63, doi:10.1111/bjso.12163.

Kerr, Philippa, and Kevin Durrheim. "The dilemma of anti-xenophobia discourse in the aftermath of violence in De Doorns". Journal of Southern African Studies, vol. 39, no. 3, 2013, pp. 577-596, doi:10.1080/03057070.2013.825133.

Kerr, Philippa, Kevin Durrheim, and John Dixon. "Xenophobic violence and struggle discourse in South Africa". Journal of Asian and African Studies, vol. 54, no. 7, 2019, pp. 995-1011, doi:10.1177/0021909619851827.

Kirshner, Joshua. "We are Gauteng people: Challenging the politics of xenophobia in Khutsong, South Africa". Antipode, vol. 44, no. 4, 2012, pp. 1307-1328, doi:10.1111/j.1467-8330.2011.00953.x.

Landau, Loren, editor. Exorcising the demons within: Xenophobia, violence and statecraft in contemporary South Africa. Johannesburg, Wits University Press, 2011. 
Landau, Loren. "Why the deadly attacks against foreigners in South Africa come as no surprise". World Post, 26 April 2015, www.huffingtonpost.com/2015/04/26/ south-africa-xenophobic-attacks_n_7119816.html. Accessed 3 January 2017.

Madlingozi, Tshepo. "Social justice in a time of neo-apartheid constitutionalism: Critiquing the anti-black economy of recognition, incorporation and distribution". Stellenbosch Law Review, vol. 1, 2017, pp. 123-147.

Mamdani, Mahmood. "Amnesty or impunity? A preliminary critique of the report of the Truth and Reconciliation Commission of South Africa (TRC)". Diacritics, vol. 32, nos. 3-4, 2002, pp. 32-59.

Mbembe, Achille. "Decolonizing knowledge and the question of the archive". Public lecture, Johannesburg, Wits Institute for Social and Economic Research (WISER), 2015. https://wiser.wits.ac.za/sites/default/files/private/Achille $\% 20 \mathrm{Mbembe} \% 20-\%$ 20Decolonizing $\% 20$ Knowledge $\% 20$ and $\% 20$ the $\% 20$ Question $\% 20$ of $\% 20$ the $\% 20$ Arch ive.pdf. Accessed 7 July 2019.

Misago, Jean-Pierre. "Responding to xenophobic violence in post-apartheid South Africa: Barking up the wrong tree?" African Human Mobility Review, vol. 2, no. 2, 2016, pp. 443-467.

Misago, Jean-Pierre. Violence, labour and the displacement of Zimbabweans in De Doorns, Western Cape. Migration Issue Brief 3. Johannesburg, Forced Migration Studies Programme, 2009.

Monson, Tamlyn. "Everyday politics and collective mobilization against foreigners in a South African shack settlement". Africa, vol. 85, 2015, pp. 131-153, doi:10.1017/ S0001972014000783.

O'Connell, Siona. "Imagining freedom in the aftermath of racial oppression in Cape Town, South Africa". Third Text, vol. 32, no 1, 2018, pp. 32-45.

Naidoo, Lee Anne. "We shall not be moved or led astray: The emergence of the 2015 student movement". New Agenda, vol. 60, 2015, pp. 12-14.

Neocosmos, Michael. From foreign natives to native foreigners: Explaining xenophobia in post-apartheid South Africa. Dakar, CODESRIA, 2006.

Neocosmos, Michael. "The politics of fear and the fear of politics". Journal of Asian and African Studies, vol. 43, no. 6, 2008, pp. 586-594, doi:10.1177/0021909608096655.

Palmary, Ingrid. Gender, sexuality and migration: Governing morality. Cham, Palgrave Macmillan/Springer, 2016.

Sinwell, Luke. 'Obtaining 'peace', searching for justice: Evaluating civil society and local government responses to xenophobia in Alexandra". Politikon, vol. 38, no. 1, 2011, pp. 131-148. doi:10.1080/02589346.2011.548674.

Solomon, Ryan. "Xenophobic violence and the ambivalence of citizenship in postapartheid South Africa”. Citizenship Studies, vol. 23, no. 2, 2019, pp. 156-171, doi:10.1080/13621025.2019.1584158.

Tafira, Kenneth. "Is xenophobia racism?" Anthropology Southern Africa, vol. 34, nos 3-4, 2011, pp. 114-121, doi:10.1080/23323256.2011.11500015.

Tromp, Beauregard. "SA's xenophobia shame: Burning man case shut". TimesLive, 15 February 2015, www.timeslive.co.za/sunday-times/lifestyle/2015-02-15-sas-xenop hobia-shame-burning-man-case-shut/. Accessed 1 February 2020.

Vale, Peter. "Migration, xenophobia and security-making in post-apartheid South Africa". Politikon, vol. 29, no. 1, 2002, pp. 7-29.

Van Zyl, Paul. "Dilemmas of transitional justice: The case of South Africa's Truth and Reconciliation Commission”. Journal of International Affairs, vol. 52, no. 2, 1999, pp. 647-667. 
Zulu, Andile. "What if we told foreigners to voetsek?" Mail \& Guardian, 27 November-3 December 2020, p. 26.

Zwelithini, KingGoodwill. Moral regeneration speech, edited by Sonke Gender Justice, 2015, https://genderjustice.org.za/project/policy-development-advocacy/challen ging-xenophobia-keeping-leaders-accountable-inciting-hate/. Accessed 15 February 2021. 



\section{Part III}

\section{Forgotten actors}





\title{
8 Diaspora communities in transitional justice
}

\author{
A hidden presence
}

\author{
Stephan Parmentier, Mina Rauschenbach and \\ Laura Hein
}

\section{Introduction}

Although diaspora communities often play a vital role in transitional justice processes, a number of facets of their engagement remain under-explored in scholarly work. They have often been described either as conflict spoilers or peace-makers (Cochrane et al. 2009), but they are less often recognized as justice actors, victims and/or political agents. Their marginalized status is also observed in transitional and post-conflict settings where diasporas are often overlooked as "justice stakeholders" by their home countries, and perceived as being out of touch with the local realities and experiences due to their resettlement elsewhere (Haider 2014). In this sense, they are truly "forgotten actors" in transitional justice.

The very notion of "diaspora" possesses a long history and is most frequently associated with broad waves of migration, which can be motivated by a variety of reasons. In this chapter, we focus specifically on "conflict-generated" diaspora communities, which are fleeing their country of residence as a result of political violence and are seeking refuge in another country. In the Spanish-speaking world, the notion of "exiles" is preferred to capture this type of migration, thus highlighting the forceful nature of leaving a place for reasons of safety and security (Bolzman 2002; Teodora and Oprescu 2013) (on Argentina, see Jensen 2014; on Colombia, see Estrada et al. 2018; Martínez Leguízamo 2017). The notions of diaspora and exiles present many similarities such as the dispersal of the group(s) in several states, the (symbolic and material) connections to their home countries, the dream of returning, and the mobilization and organization of the group(s) to influence their home countries. Moreover, the work of memory and the recognition of their experiences give meaning to their presence abroad and grant them a legitimate (and sometimes constitutive) place as citizens and interlocutors in their country of origin (Bolzman 2002).

Particularly interesting for the scope of this chapter is that diasporas are recognized in their ability to develop an identity of their own, as well as an organizational project (Hovanessian, cited in Bolzman 2002). This refers to the capacity of the diaspora to transform forced migration into a "minority

DOI: $10.4324 / 9781003167280-11$ 
conscience", and to make themselves visible in the socio-political scene through their mobilization. In short, a diaspora is identified as such when it exists as a social actor (Bolzman 2002).

Scholarship has only begun to decipher the patterns, potential and challenges attached to diaspora engagement in transitional justice and is still very limited to sporadic analyses of their role in these processes. The involvement of diasporas in transitional justice is increasingly acknowledged from a double perspective (Wiebelhaus-Brahm 2016): first, as key justice stakeholders who can contribute to providing a comprehensive account of human rights violations committed in a country; and second, as direct victims of human rights violations back home and possessing the right to have their suffering acknowledged, akin to the citizens in their country of origin. Transitional justice scholars are progressively giving attention to diaspora activism and some studies have sketched the benefits attached to their engagement in transitional justice processes (Haider 2014; Young and Park 2009). Furthermore, in some cases important steps have been taken to incorporate diasporas in transitional justice measures (Bradley 2013; Haider 2014) in various ways: in providing input to transitional justice strategies (such as those in Haiti, Iraq, Kenya, Zimbabwe); in awareness-raising initiatives (e.g. Argentina, Armenia, Chile, Liberia and Sri Lanka); in the design and implementation of transitional justice measures (e.g. East Timor, Liberia, Sierra Leone); in supporting justice initiatives and providing evidence for these in their host country (i.e. Argentina, Cambodia, Chile, Rwanda, Syria); in truth commission processes (e.g. Colombia, Liberia).

Analysing all possible forms of diaspora engagement in transitional justice processes goes beyond the scope and objective of this chapter. Instead, we look at them with a particular focus on the role of turning points and transformative events in diaspora engagement, the types of transnational engagement observed in those communities, and the place of memory as a lynchpin of exiles' struggles for recognition.

The dimension of memory is particularly relevant to understanding the engagement of diaspora communities in transitional justice. Conflict-generated diasporas carry general memories of political violence and a troubled past, and specific memories of traumatic events and of loss (Lacroix and Fiddian-Qasmiyeh 2013). Memory practices can serve as symbolic forms of justice in that they are meant to acknowledge victims' experiences and suffering (Jimeno 2018; Rauschenbach et al. 2020). In addition, these memories shape diasporas' experiences, narratives and claims for justice in several ways. First, memories circulate and are transformed in interaction with the emergence and implementation of transitional justice processes. Moreover, these processes are often conceived and implemented in settings with contested understandings of a violent past (Jelin 2003; McEvoy and McGregor 2008), and this heterogeneity in historical representations can also be observed within diaspora communities. For example, in the case of Sri Lankan Tamils, the way in which the past may be understood (and its 
meaning for the present) can depend on factors such as different migration experiences, social and ethnic status, and the extent to which one identifies with the Tamil nationalist political project (Orjuela 2008; McDowell 2011; Étiemble 2017). Furthermore, the memories that drive diasporas' engagement in transitional justice processes are inevitably subjected to power relations, which may result in the marginalization of some experiences to the profit of other dominant accounts of the past. In the Tamil Sri Lankan diaspora, powerful and politicized subsections of these communities have engaged in the selective instrumentalization of particular narratives of the past aimed to legitimize their separatist and nationalist claims, resulting in the silencing of many other (individual and collective) narratives (Orjuela 2008).

Various factors can account for the heterogeneity and the relative salience of specific framings of the past in diasporas' relations to transitional justice at home. They include, first of all, diaspora migration experiences and organizational characteristics, and how these interact with the agendas and interests of their members (Orjuela 2008) and the political fields and opportunities of the home and host settings (Amarasingam 2015; Koinova and Karabegovic 2019). Moreover, these factors are linked to differences in access to broader international and transnational political fields and the actors occupying them, such as advocacy groups, the media, etc. (WiebelhausBrahm 2016). Finally, they are related to the legal and moral normative frameworks within which the discourse and practice of transitional justice are embedded (Orjuela 2018). Thus, depending on the context and time, diasporas may not have access to public and official spaces for the acknowledgement of their understandings of the past and institutions promoting them. In such cases, they are likely to resort to more informal and collective spaces of recognition such as digital platforms of exchanges or oral history projects (Karabegović 2014), private spaces (family events in the home) or personal modes of "mnemonic engagement" (e.g. family photography; oral histories) to uphold their memories within their collective consciousness (Halilovich 2014; Van Hear and Liberatore 2015).

We illustrate various forms of diaspora engagement with transitional justice processes through two examples from Latin America, namely the cases of Argentina and Colombia. These two case studies were chosen because of their relevance to factors highlighted as important in influencing the willingness and ability of diaspora communities to shape transitional justice politics in their home countries (e.g. Wiebelhaus-Brahm 2016). On the one hand, these factors include the socio-political characteristics of diaspora members and of the perpetrators of historic violence, the way in which some sort of political transition emerges (in a post-authoritarian context for Argentina and a peace process in a context of ongoing conflict for Colombia), and the world-historical time period in which transitional justice discussions take place (the birth of transitional justice in Argentina in a Cold War context, and the holistic view of transitional justice in Colombia as part 
of a contemporary globalized world order). On the other hand, both cases show similarities regarding the nature of the violence to be addressed (in both cases political violence), and the specific place of memory and its determining role in shaping and keeping the mobilization going, in providing meaning to a collective identification as an exile community and in bolstering the struggle for justice and truth.

\section{Two case studies of diaspora participation in transitional justice processes}

Exile from Argentina was the direct result of the political violence and repressive practices applied by the last military regime (1976-83) through its "anti-subversive struggle" against all (supposed) opponents. Recent studies estimate that up to 340,000 individuals were exiled during this period (Yankelevich 2007) with their main destinations being other countries in Latin America, Europe and the United States. Overall, the Argentine diaspora was composed of highly educated individuals and socio-political activists, which constituted the very reason for their persecution by the military regime (Wiebelhaus-Brahm 2016). Argentina is frequently considered a pioneer in dealing with human rights abuses during this particular period, because of its strong endeavours to implement a variety of political and legal strategies for the sake of justice and accountability. Since 1983, it has experienced a long and complex transitional justice process, consisting of several periods that have progressed in a non-linear fashion. The first period, during which the National Commission on the Disappearance of Persons (CONADEP) was established and the trials against the military junta were held, was followed by a long period of impunity and oblivion based on the impunity laws, and later by the still ongoing initiatives for truth and justice. Diaspora communities have been deeply involved in all phases of the transitional justice process in Argentina, but their precise roles have barely been explored.

Colombia, for its part, has been the theatre of more than 50 years of protracted and violent conflict involving multiple armed actors with various agendas (Díaz Pabón 2018). The conflict has affected populations from very diverse communities, different social classes and ethnic groups, who were located in different territorial spaces. Forced displacement, resulting in massive internal and international population movements, is one of the most prevalent human rights violations observed in this conflict. Overall, more than seven million Colombians have been forcibly displaced: at least six million have been internally displaced and more than one million have migrated out of Colombia due to the conflict but also because of inequality and lack of economic opportunities (Bermudez 2016; Swisspeace 2019). The recent peace process has provided the diaspora communities with unique opportunities to get involved in the transitional justice mechanisms and thus to become justice stakeholders, besides already being political actors. Following 
the peace accords of 2016, diaspora participation has been included in the mandate of three bodies established within the comprehensive justice framework: the Commission for the Clarification of Truth, Coexistence, and NonRepetition (hereafter TC), the Search Unit for Missing Persons and the Special Jurisdiction for Peace (hereafter JEP). Diaspora communities have been involved from the onset in the workings of the TC and the JEP. Yet there are many concerns about whether this inclusion will translate into effective participation (ICTJ 2018), particularly because of the lack of political will (Estrada et al. 2018). The TC's policy of inclusion of Colombian exiled voices is unprecedented in its scope, as it aims to account for the differentiated impacts of forced migration across the different social and ethnic groups represented in Colombia, and to collect pluralistic documentation of experiences across different host countries. These objectives are sought by organizing the international component of the TC in collaborative networks of nodes situated in various European, Northern American and Latin American countries.

\section{Different exiles' engagement and the role of turning points and "transformative events"}

Concerning Argentina, the general objectives of the exiles' activism, as well as their specific claims, clearly changed over time. Three partly overlapping phases of mobilization can be distinguished. They are closely related to socio-political transformations within the home country, as well as to the international and regional context that witnessed an increasing recognition of the legitimacy of human rights norms.

First, during the military junta period (1976-83) the aim of the exiles was mainly to denounce what was happening in Argentina and to put international pressure on the regime to halt the repression by means of collecting evidence and engaging in awareness-raising initiatives. A second phase of mobilization started with the end of the military regime and the transition to democracy. The Argentine exile communities reshaped their aims and gave support to several types of transitional justice mechanisms: the CONADEP truth commission established in 1984, and, simultaneously, the pursuit of the legal accountability of the Argentine perpetrators both in their own country as well as in that of their hosts. However, with the enactment of impunity laws (Ley de Punto Final 1986 and Ley de Obediencia Debida 1987), it became very clear that the Argentine state was no longer willing to prosecute those responsible. Disappointed by their home country, some exiles pursued cases in foreign courts based on the principles of universal jurisdiction and "passive personality" (with victims also possessing the nationality of the specific country), in countries such as Italy, France, Germany and Spain. During that period the primary goal was to put pressure on Argentina to open its domestic avenues for pursuing criminal justice. And indeed, the pressure caused by the criminal trials abroad was one of the key arguments 


\section{Stephan Parmentier, Mina Rauschenbach and Laura Hein}

brought into the parliamentary debates that preceded the annulment of the impunity laws in 2003. From the mid-1990s onwards, a third wave of exile activism arose from those who remained in the diaspora abroad, but even more so from those exiles who had returned to Argentina. They progressively mobilized for the acknowledgement of exile as a separate violation of human rights, their right to reparations, and the inclusion of their memories within the broader national narrative of the past, to voice their experiences and to be recognized as political actors in supporting the transitional justice process. Particularly in this phase, the Argentine exiles gradually emerged as justice stakeholders in Argentine society with very specific claims for the recognition of their own narratives and memories of the past, and of exile as a specific form of state repression.

An important transformative event for the mobilization of Argentine exiles was the arrest of former General Pinochet in London in 1998, which was particularly significant to sustain and legitimize the pursuit of the legal accountability of the Argentine perpetrators abroad. It energized the Argentine exiles, mostly in Europe, to pursue their search for accountability in their host countries (Roht-Arriaza 2005). Moreover, the confession in 1995 of former naval Captain Scilingo of his participation in the so-called death flights (vuelos de la muerte) strongly revitalized the Argentine public debate about the crimes committed by the junta. As a result, this "boom of memory" (Jensen 2014) in Argentine society sparked a new interest in the exiles' experiences, and in exile as a specific form of state repression.

The conflict in Colombia is a long-standing one, resulting in Colombians seeking political exile for the last 30 years, particularly during periods of peaking violence (Estrada et al. 2018). Yet before the onset of the peace process, only a minority of the diaspora was engaged in the denunciation of human rights violations and political activism in relation to the homeland (Bermudez 2016).

Granting participation possibilities to victims in the peace accords gave a special impetus for exiles, as historically overlooked justice stakeholders (Bedoya 2019), to claim their right to be included. The accords provided a particular momentum for Colombians living abroad to be recognized as justice stakeholders at the negotiation table and to be included in the development of the new political scenario that would follow (CNMH 2018; Martínez Leguízamo 2017). In addition to sending their inputs to the Havana process, diaspora members were included in victims' delegations in the third round of negotiations which allowed them to have their stories, as well as their justice and reparations needs, recognized in the Dialogue Agenda (Martínez Leguízamo 2017). The diaspora was also instrumental in placing the Colombian peace process and its relevance on the international agenda. Through numerous activities of lobbying and advocacy in their host countries, as well as the development of national and transnational networking initiatives (throughout Europe, South America and North America), the exiled have organized collectively and increased progressively their visibility as potential 
agents of change (Bermudez 2016; Martínez Leguízamo 2017; De Ryck and Lopez Villamil 2020). With their current participation in the different mechanisms developed within the comprehensive justice framework resulting from the peace accords, as well as the development of transnational networks of Colombian diasporas, the Colombia diaspora's engagement has thus been bolstered.

\section{Types of diaspora mobilizations}

One significant feature of the Argentinian exiles' activism, mainly in the late 1970s and early 1980s, was their engagement in transnational networking. They built networks between Argentine diaspora communities based in different countries and other diaspora communities (such as the Chilean ones), as well as alliances with international human rights organizations (such as Human Rights Watch and Amnesty International). This allowed the exiles to achieve international solidarity, and to appeal to the international community and public opinion to put pressure on the Argentine regime (e.g. Wiebelhaus-Brahm 2016; Franco and Pérez 2007). Alongside these more "horizontal forms of coordination" with civil society actors, the Argentine diaspora also engaged in "vertical coordination" with political actors in their host countries as well as with international political institutions such as the European Union (EU), the United States and also with the Vatican state. Despite being confined to certain sectors and only a fraction of the Argentine diaspora (Franco and Pérez 2007), several exiles' organizations were founded in Europe and Latin America. One particularly active exile organization was the Comisión Argentina de Derechos Humanos that had its major delegations in Paris, Mexico and Madrid, and intervened in the anti-junta fight mainly through its legal expertise. Indeed, another important characteristic of the Argentine diaspora mobilization of that period was that it accompanied humanitarian activism with a specific legal focus. In particular, the legal strategy explored the possibilities of legal protection under international human rights law and criminal prosecutions via international criminal jurisdictions. In this sense, from the very start, the exile communities went beyond the political and moral condemnation of serious human rights violations to walk the path of legal justice. Indeed, after the end of the military regime, the exiles played a crucial role in promoting the start of criminal trials in their host countries: as witnesses; by providing information and informal channels to access documents and testimonies; by giving logistical and financial support to witnesses travelling from Argentina; and by mobilizing public support (Roht-Arriaza 2005; Lutz and Sikkink 2001).

The founding document of the Argentine organization Hijas y Hijos del Exilio (2006) states:

Exile and its consequences were relegated as if it was a minor violation, unimportant; but many silences and omissions did not erase the 
wounds ... We need to tell our story and we want that the exile be treated as what it is: a violation of human rights.

(Translated from Spanish)

From the mid-1990s, former exiles founded their own organizations in Argentina (the Comisión de Ex-exiliados Argentinos por la Reparación CER - in 1998; the Comisión de Exiliados Políticos de la República Argentina - COEPRA - also in 1998; the Hijas y Hijos del Exilio in 2006) as well as abroad (Comisión de Exiliados Argentinos en Madrid - CEA-M - in 1999). Their objectives were primarily to obtain acknowledgement by the Argentine state that their exile was a consequence of forced displacement, and hence a human rights violation committed as part of the ideological depuration plan of the military junta, and the right to reparation deriving therefrom; to seek recognition of their role as political actors in denouncing the regime and in pursuing accountability; and to give voice to the exile experiences as part of an inclusive collective memory of the past. The national and international mobilization of exiles focused mainly on support for the draft law, the Reparación al Exilio (1998), which proposed a system of financial compensation for the exiles. Alongside very concrete claims (such as the recognition of titles and studies carried out abroad, and the acceptance of children of exiles as victims of the repression), the exiles' discourses drew attention to the symbolic and political aspects of the draft law: "our main claim is not monetary: we want a law that recognizes exile as a violation of human rights" (translated from Spanish. Pagina 12 2006; interview with Miguel Schclarek at COEPRA).

While the draft law was not approved, mostly because of the economic aspects, the judicial system from the late 1990s onwards started to accept reparation claims from exiles. Judges (up to the Supreme Court) began to recognize exile as a human rights violation, a deliberate practice of the military regime and, consequently, a harm that needed repairing.

In contrast, the Colombian diaspora cannot be described as a strong, widespread and organized movement overall, although it has become more visible and active in the transformation processes after signing of the peace accord. Private and individual forms of transnational engagement, particularly in relation to historical memory, have traditionally been more frequent than collective and public ones (Bermudez 2016). Only a minority of diaspora members were engaged in relation to the peace process, mostly individuals with a history of activism in Colombia and for whom such engagement was possible in the host society; either by their having a stable migrant status or such favourable economic circumstances that their engagement was not impeded by trauma. Moreover, diaspora engagement suffered from fragmentation within these migrant communities, related to gender, class, racial and regional divisions, which reflect the same cleavages existing in Colombia (Bermudez 2016). Divides also related to political identities, and what they imply in terms of expectations in relation to the peace process, with some diaspora members more likely to 
claim victim status, while others reject this status to the benefit of political agency (Dosdad and Louidor 2018). Colombian exiles have generally not benefited much from support from the Colombian state or its institutions, but their mobilization has significantly grown over the past 20 years due to the existence of effective opportunities in host societies. The Colombian state also reached out to the diaspora communities via the Ministry of Foreign Affairs and the National Centre for Historical Memory.

While the Colombian state has provided only limited support for diaspora engagement, political opportunity structures in certain host countries, particularly since the onset of the peace process, have facilitated its development into an organized movement, through possibilities for networking, advocacy as well as lobbying with local political leaders and institutions. Their mobilization has involved both horizontal coordination (i.e. relationships with civil society actors), and vertical coordination (i.e. relationships with host country policymakers and international organizations) (Stokke and Wiebelhaus-Brahm 2019). For example, Colombian exiles' organizations have developed significant transnational networks in Spain and the United Kingdom, involving government bodies, trade unions, non-governmental organizations, and human rights and academic institutions. Some of these organizations are also part of a broader transnational network of organizations, called the Oficina Internacional de los Derechos Humanos Acción Colombia (International Bureau for Human Rights Action on Colombia), involved in political advocacy with European institutions, states and the United Nations (UN), in relation to human rights issues in Colombia. These transnational activities, of raising public awareness and lobbying politicians, have helped to sustain the Colombian diaspora's engagement, as well as to strengthen European and international support for the peace process. While they are generally considered to offer less capacity to exiles to mobilize compared to organizations in Europe, national organizations based in various Latin American countries, including Mexico, Costa Rica, Chile, Argentina or Peru, have also been developed to support the struggle for the visibility of the victimization of Colombian exiles. Transnational networks, such as Revicpaz-LAC (Network of Colombian Victims for Peace in Latin American and the Caribbean) which were built on the legacy of regional exile experiences are also very active in supporting advocacy for Colombian exiles' visibility as justice stakeholders.

Informal civil society-led truth-seeking initiatives developed outside of Colombia also had a significant role in contributing to the active inclusion of diaspora perspectives in the peace process. An example is the Truth, Memory, and Reconciliation Commission of Colombian Women in the Diaspora, which was created in 2014 and has hubs in London, Barcelona, Brussels and Stockholm. Through the adoption of an active memory and empowerment approach, this Commission aims to highlight and document the role of women in exile and their specific and often marginalized experiences. Another initiative is the Foro Internacional de Victimas (International 
Victims Forum) created in 2014 which is a transnational network with coordinators in 18 cities across the world and which organizes events aimed at diaspora engagement in the peace process. It serves as a platform for communication, organization and participative action aimed at increasing the visibility of victims of the conflict abroad and at promoting their participation in the peace process.

\section{Memory as a lynchpin of exiles' struggles for recognition}

In Argentina, during the early years of the transition to democracy, exile experiences were marginalized in relation to other experiences of repression (Jensen 2014). The reasons for this marginalization were manifold. Public opinion was still influenced by the stigmatizing discourses of the junta against the exiles (accusing them of conducting an anti-Argentina campaign abroad), as well as by the prejudice of a "golden exile". Furthermore, the experiences of exiles were conditioned by a hierarchical logic of victims that compared the degree of suffering or damage of the exiles with respect to prison, death or disappearance (Jensen 2014). The exiles' sense of guilt, that they were "privileged among the victims", led them to stay silent about their experiences and consequently facilitated the marginalization of the exiles in the general discourses and memories about the repression.

Since the mid-1990s, however, there has been an increasing repositioning of exiles in memories of the repression alongside a boom of memory in Argentinian society. A new social interest in the exile emerged that helped to re-signify it as another repressive practice of the junta. Initially, such interest was expressed mainly in the publication of literature (biographies, life stories, interviews) and public debates that emphasized the individual and human dimension of the exiles' experiences. As exiles started to obtain a place in memories of the repression, groups of exiles mobilized further for the public acknowledgement of the political and collective dimension of the exiles' experiences, i.e. for the recognition of forced displacement as part of a planned cultural repression by the junta, thus placing the exiles among the victims of its ideological depuration. While the judicial recognition of reparations to exiles as victims of human rights violations was a first important step, it also remained an incomplete solution for the exiles since it limited the debate around reparations to its strictly material dimension. Furthermore, it led the exiles to search for individual judicial solutions, which again undermined the recognition of the collective dimension of exile, as well as the official and political acknowledgement of exiles' experiences. This lack of recognition of the political and collective dimension is the reason why exiles speak about "memorias lights", or "memorias anestesiadas" ("anesthetised memories"), when referring to the place of their experiences in Argentine society (Jensen 2014).

Within the context of the ongoing conflict in Colombia, "memory is an expression of rebellion against violence and impunity" (Schultz-Kraft 2017) 
and recovering the historical memory of the conflict is understood as a central, forward-looking process for victims to claim justice and reparation (Tamayo Gomez 2019). Within this broader process of collective memorymaking, Colombians who were forced to migrate have struggled, sometimes for decades, to have their exile recognized as an injustice resulting from the armed conflict. This struggle for visibility is complicated by official denial or by the perception of Colombia as a democratic state affected by an armed conflict, rather than as dictatorship like many other cases of exile in Latin America (Estrada et al. 2018). Within this context, individual and collective commemorative practices have acted as channels of recognition through which exiles have been able to keep their memories alive and continue their struggle for justice and reparation (Bermudez 2011; CNMH 2018). This was particularly important for exiles in the face of the invisibility of their victimhood back home until it was officially recognized in the peace agreements of 2016.

A noteworthy initiative which has helped to disseminate exiles' experiences within Colombia is the creation by the Centro Nacional de Memoria Histórica (CNMH - National Centre for Historical Memory) of a virtual space for Las voces del exilio (the Voices from Exile). This initiative was followed by a report aimed at "recognizing exile as a form of violence that has transversally affected the lives of individuals, groups and communities in exile around the world, as well as those who have returned to the country voluntarily or forcibly" (CNMH 2018, 17). This report describes also how remembrance practices aimed at preserving identity through language, food and other traditional practices, serve as forms of resistance against the uprooting that the exiled have suffered and as guarantees of non-repetition of past injustices (CNMH 2018). Moreover, informal initiatives such as the Truth, Memory, and Reconciliation Commission of Colombian Women in the Diaspora have focused specifically on the active promotion of women's perspectives in the reconstruction of historical memory, with the objective to break the double invisibility of exiled women (Bermudez 2016). More recently, Colombia's Truth and Reconciliation Commission (TRC), which began its mandate in late November 2018, has been working actively with exiles to collect their testimonies, individually and collectively, in order to recognize and give visibility to the role and impact of exile in Colombia's conflict. This truth-telling mechanism, for the very first time, gives exiles a voice. As Dr Carlos Beristain, a member of the TRC explained at a seminar in Brussels in October 2019, "[t]here is a truth about Colombia outside the country and we need to voice it". This TRC employs not only methodologies of testimony gathering, but also artistic practices to facilitate the expression of exiles' experiences and to promote their inclusion in the construction of the memory of the conflict in a participatory and healing manner. While the Colombian TRC displays much promise in its objectives and in its pioneering active inclusion of exiles, there are concerns about what it will be able to achieve, given its very short mandate (which was scheduled to end in 2021), 
and the unfavourable Colombian political context (Bermùdez Liévano 2020). The challenge given this polarized home context is to ensure that historically marginalized voices are included meaningfully and to have them acknowledged by the Colombian state.

\section{Discussion: lessons learnt from Argentina and Colombia}

These two prominent case studies can produce several interesting insights into the central theme of our chapter, namely to better understand the engagement of diaspora communities with transitional justice, with a particular focus on memory.

Both cases amply demonstrate the important contribution of diaspora communities to transitional justice, both in the host and the home countries. In the case of Argentina, during the military junta the aim of the exiles was mainly to increase international pressure on the regime to halt the ongoing repression. After the fall of the dictatorship, the exiles oriented their activities to ascertain the legal accountability of the Argentine perpetrators in their home settings and host countries (Sikkink 2012). From the mid-1990s, the exiles progressively mobilized for the acknowledgement of exile as a violation of human rights and the inclusion of their memories within the broader national narrative of the past. During this particular phase they emerged as specific justice stakeholders claiming the acknowledgement of their own narratives as a transnational community with shared experiences of exile. In the Colombian case, the exiles were truly forgotten actors and memory served as a key form of symbolic reparation until the final stages of the peace accords in 2016, when they suddenly emerged as justice stakeholders. With the increasing inclusion of victims within the transitional justice process, the struggle for the acknowledgement of the exiles' memories shifted from a more personal form to a more collective and organized one, as illustrated by initiatives such as the Voices from Exile and the Truth, Memory, and Reconciliation Commission of Colombian Women in the Diaspora. These collective initiatives and the late involvement of exiles in the peace accords made it impossible for the Colombian state to continue to overlook the voices of the exiles in the upcoming post-agreement justice process.

The differences in both cases are perfectly logical, as they reflect different approaches to transitional justice and different contexts. In the case of Argentina, the exile communities strongly focused on criminal accountability as the central form of transitional justice, while in the Colombian case the time was ripe for a more holistic approach, which also included elements of restorative justice and victim reparations. Moreover, the transitional justice dynamics were quite different. In the case of Argentina, most strategies and actions of transitional justice came from within the country and built on the work of the existing institutions of justice and memory. In contrast, Colombia shows the prominent role of the international community (such as the $\mathrm{UN}$ and the EU) in shaping the transitional justice process and its activities. 
This was partly due to the rapid development since 1995 of transitional justice as a broad and global field of research, policymaking and practice. Furthermore, the Colombian exiles were less organized in their mobilization efforts, mostly due to their heterogeneity, as opposed to the Argentinian exiles who were more homogenous and proactive.

Despite the many differences, several similarities also emerge from these brief case overviews. Both cases illustrate the importance of diaspora communities being actively involved in transitional justice institutions and arrangements, in order to raise awareness, provide evidence, push for truth and justice and, let us not to forget, also advocate for reparations for the victims of serious human rights violations, including their own victimization as exiles. Moreover, in both cases, the diasporas evolved from forgotten actors to justice stakeholders by means of a struggle for remembrance. From this perspective, they can easily be seen as stakeholders who shaped and transformed their victimhood into political and legal action, both in the host setting and the home country. Finally, both cases illustrate the non-linear shape of historical evolutions, which unfold as waves and cycles that come with ups and downs, as well as the importance of "turning points" and "transformative events" (Koinova 2018). In Colombia, it was definitely the peace process and the resulting accords, while in Argentina it was the combination of the Pinochet effect and the memory boom.

The two cases also provide ample evidence to explore theoretical frameworks concerning the engagement of diaspora communities with transitional justice. In terms of the benefits for transitional justice processes to engage with diaspora communities, both cases clearly illustrate the relevance of Wiebelhaus-Brahms' (2016) framework. Including the experiences of the Argentine and Colombian diaspora communities in truth and justice institutions has produced a fuller account of past human rights violations. Moreover, both diaspora communities clearly pushed for truth and justice for the violations committed against them, including exile as such, and for having their own suffering acknowledged and compensated. Finally, while it seems that individuals engaged in the Argentine and Colombian diasporas also acquired a greater stake in contributing to their countries' futures, this aspect must be the subject of further studies.

In recent years, a wide range of scholarship has contributed to a better understanding of diasporas' engagement with transitional justice institutions and procedures (see also Koinova and Karabegovic 2019). Several aspects find a clear connection with the experiences and working methods of the Argentine and Colombian diaspora communities. First, both communities (but particularly the Argentine diaspora) have successfully made use of "strategic framing" (Adamson 2013), by presenting external displacement as a specific type of human rights violations, and thus insisting on the notion of exiles rather than diaspora. Second, both communities can be seen to have acted as "brokers" (Adamson 2013) between different sectors of society involved in various ways in human rights, justice and peace. More 
specifically, both exile communities were very active in "coordination activities" (Karabegovic 2019), first by forming links with other diaspora communities and groups of human rights activists, and second by undertaking strong lobbying with policymakers, the media, etc. through institutional channels in their host countries and regions (such as the EU). Finally, both cases also clearly illustrate the "boomerang effect" (Keck and Sikkink 1998), whereby the diaspora communities solicited transnational and international actors in order to pressurize their home states to cease committing human rights violations and, later on, to step up transitional justice efforts to deal with past human rights violations.

\section{Conclusion}

In this chapter, we have focused on the role of diaspora communities as transnational actors in various transitional justice processes in two geographical settings: first, in relation to their home countries, which they have left behind (and often wish to return to); and second, in relation to their new host countries. From the limited examples available, it is clear that, overall, diaspora communities thus far are forgotten actors in transitional justice processes. Yet they often play an important role in raising awareness about human rights violations in their home state, in providing evidence and support to transitional justice institutions, and in advocating institutions that seek for truth, justice and/or reparations. In this line, diaspora communities have emerged in various settings as justice stakeholders in the domestic and international spheres. The role of remembrance in these endeavours is crucial, both at the individual level and the more collective one, as a symbolic form of transitional justice, especially when there is not (yet) a space for further forms of transitional justice. Although diaspora communities occupy a very specific position in between these different worlds, their presence frequently tends to remain hidden until specific turning points and transformative events enable them to become more visible.

While concise, the two case discussions of Argentina and Colombia have provided more elements to understand the particular backgrounds, working methods and objectives that diaspora communities draw upon. While postdictatorship Argentina constitutes a classical example in the field of transitional justice, with a clear focus on the criminal accountability of perpetrators, Colombia is a more recent case, displaying a holistic and innovative approach to dealing with past abuses. Both cases also illustrate the importance of expanding in-depth empirical case studies in order to broaden theoretical frameworks.

Finally, the experiences of Argentina and Colombia open the door for more research on more recent ongoing violent conflicts such as those in Afghanistan, Syria or Myanmar. These conflicts produce yet more exiles on a daily basis as well as new conflict-generated diaspora communities, whose very essence lies in their forced displacement to other countries and regions of the world. 


\section{References}

Adamson, Fiona. "Mechanisms of diaspora mobilization and the transnationalization of civil war". Transnational dynamics of civil war, edited by Jeffrey Checkel, Cambridge, Cambridge University Press, 2013, pp. 63-88, doi:10.1017/ CBO9781139179089.

Amarasingam, Amarnath. Pain, pride and politics: Social movement activism and the Sri Lankan Tamil diaspora in Canada. Athens, University of Georgia Press, 2015.

Bauböck, Faist T., editor. "Diaspora and transnationalism: Concepts, theories and methods". IMISCOE research, Amsterdam, Amsterdam University Press, 2010, https://cadmus.eui.eu/bitstream/handle/1814/14318/Diaspora_and_Transnationalis m.pdf. Accessed 12 February 2021.

Bedoya, Nicolas. As violence continues at home, exiled Colombians reconstruct collective memory. 2019, https://atindispatch.com/2019/04/18/as-violence-continues-a t-home-exiled-colombians-reconstruct-collective-memory. Accessed 14 December 2020.

Bermudez, Anastasia. "The 'diaspora politics' of Colombian migrants in the UK and Spain”. International Migration, vol. 49, no. 3, 2011, pp. 125-143, doi:10.1111/ j.1468-2435.2011.00689.x.

Bermudez, Anastasia. International migration, transnational politics and conflict: The gendered experiences of Colombian migrants in Europe. London, Palgrave Macmillan, 2016, doi:10.1057/978-1-137-53197-1.

Bermùdez Liévano, Andrés. Political tussle over truth and memory and Colombia. 2020, www.justiceinfo.net/en/truth-commissions/44027-political-tussle-over-truth-a nd-memory-in-colombia.html. Accessed 14 December 2020.

Bolzman, Claudio. "De l'exil à la diaspora: L'exemple de la migration chilienne", Autrepart, 2002, vol. 2, no. 22, pp. 91-107, www.cairn.info/revue-autrepa rt-2002-2-page-91.htm. Accessed 12 February 2021.

Bolzman, Claudio. "Elementos para una aproximación teórica al exilio". Revista andaluza de antropología, no. 3, 2012, Migraciones en la globalización, http://asana -andalucia.org/revista/uploads/raa/n3/claudio.pdf. Accessed 12 February 2021.

Bradley, Megan. Truth-telling and displacement: Patterns and prospects. Advancing Transitional Justice Series. Washington, DC, Brookings-LSE Project on Internal Displacement, 2013, www.ictj.org/sites/default/files/ICTJ-Research-Brief-Displacem ent-Truth-Bradley.pdf. Accessed 19 July 2021.

Bradley, Megan and Roger Duthie. Doing justice for refugees and IDPs? Confronting displacement through transitional justice. Washington, DC, Brookings Institution, 2012, www.brookings.edu/opinions/doing-justice-for-refugees-and-idps-confronting-displace ment-through-transitional-justice. Accessed 14 December 2020.

Centro Nacional de Memoria Historica (CNMH). Exilio Colombiano. Huellas del conflicto armado más allá de las fronteras. Bogotá, CNMH, 2018, https://centrodem emoriahistorica.gov.co/exilio-colombiano-huellas-del-conflicto-armado-mas-alla-de -las-fronteras. Accessed 15 December 2020.

Cochrane, Feargal, Baser, Bahar, and Swain, Ashok. "Home Thoughts from Abroad: Diasporas and Peace-Building in Northern Ireland and Sri Lanka". Studies in Conflict \& Terrorism, vol. 32, no. 8, 2009, pp. 681-704,doi:10.1080/10576100903040716.

De Ryck, Paul, and Stéphanie Lopez Villamil. "Challenges to the governance of the return of victims abroad to Colombia". Oxford Monitor of Forced Migration, vol. 8, no. 2, 2020, pp. 88-102, www.researchgate.net/publication/338411822_Challenges_to_ 


\section{Stephan Parmentier, Mina Rauschenbach and Laura Hein}

the_Governance_of_the_Return_of_Victims_Abroad_to_Colombia/citations. Accessed 12 February 2021.

Díaz Pabón, Fabio Andrés, editor. "Transitional justice and the 'Colombian peace process"”. Truth, Justice and Reconciliation in Colombia. Transitioning from Violence, London, Routledge, 2018, doi:10.4324/9781315148373.

Dosdad, Ángela Iranzo, and Wooldy Edson Louidor. "Entre la guerra y la paz: los lugares de la diáspora colombiana”. Bogotá, Universidad de los Andes y Pontificia Universidad Javeriana, 2018, https://uniandes.edu.co/es/publicaciones/libro-entre-la -guerra-y-la-paz-los-lugares-de-la-diaspora-colombiana-angela-iranzo-dosdad-y-w ooldy-edson-louidor-edicion-academica-y-compilacion. Accessed 15 December 2020.

Estrada Rodriguez, Johanne Alexis, and Jorge Enrique Aponte Otalvaro. "Memories of political exile in the armed conflict in Colombia: contributions to the postagreement". Ciudad Paz-ando, vol. 11, no. 2, 2018, pp. 52-60, doi:10.14483/ $2422278 X .13086$.

Étiemble, Angélina. "Tamouls du Sri Lanka en France: Politisation de l'exil dans l'ombre des Tigres". Revue européenne des migrations internationales, vol. 33, no, 4, 2017, pp. 65-86, doi:10.4000/remi.9376.

Franco, Marina, and Carlos Pérez. "Between urgency and strategy: Argentine exiles in Paris, 1976-1983”. Latin American Perspectives, vol. 34, no. 4, 2007, pp. 50-67, doi:10.1177/0094582X07302906.

Gomez, Diana. "Les droits des victimes dans les accords de paix de la Havane". IdeAs, 2017, http://journals.openedition.org/ideas/1846. Accessed 15 December 2020, doi:10.4000/ideas.1846.

Haider, Huma. "Transnational transitional justice and reconciliation: The participation of conflict-generated diasporas in addressing the legacies of mass violence". Journal of Refugee Studies, vol. 27, no. 2, 2014, pp. 207-233, https://doi.org/10. 1093/jrs/feu002.

Halilovich, Hariz. "Reclaiming erased lives: Archives, records and memories in postwar Bosnia and the Bosnian diaspora”. Archival Science, 2014, pp. 231-247.

Hijas y Hijos del Exilio. Carta Abierta de Hijas y Hijos del Exilio. 2006, www.facebook. com/permalink.php?story_fbid=1582175202095712\&id=1582161152097117. Accessed 14 February 2021.

International Center for Transitional Justice, "Colombia's Truth Commission prepares to embark on the extra-territorial truth-telling process", www.ictj.org/news/ colombia $\% \mathrm{E} 2 \% 80 \% 99 \mathrm{~s}$-truth-commission-prepares-embark-extraterritorial-truth-t elling-process. Accessed 24 July 2021.

Jelin, Elisabeth. State Repression and the Labors of Memory. Minneapolis, University of Minnesota Press, 2003.

Jensen Silvina. "Memorias Lights, memorias anestesiadas. Reflexiones acerca de los olvidos del exilio en el relato público y social de los setenta en la Argentina". Los usos del olvido: recorridos, dimensiones y nuevas preguntas, edited by Patricia G. Flier, Rosario, Prohistoria Ediciones, 2014.

Jimeno, Eliana. "Historical memory as symbolic reparation". Truth, Justice and Reconciliation in Colombia: Transitioning from Violence, edited by Fabio Andrés Díaz Pabón, London, Routledge, 2018, pp. 136-153, doi:10.4324/9781315148373-9.

Karabegović, Dženeta. "Što Te Nema?: Transnational cultural production in the diaspora in response to the Srebrenica genocide". Nationalism and Ethnic Politics, vol. 20, no. 4, 2014, pp. 455-475, https://doi.org/10.1080/13537113.2014.969151. 
Karabegović, Dženeta. "Who chooses to remember? Diaspora participation in memorialization initiatives". Ethnic and Racial Studies, vol. 42, no. 11, 2019, pp. 19111929, doi:10.1080/01419870.2019.1577473.

Keck, Margaret E., and Kathryn Sikkink. Activists beyond borders: Advocacy networks in international politics. Ithaca, NY, Cornell University Press, 1998.

Koinova, Maria. "Critical junctures and transformative events in diaspora mobilisation for Kosovo and Palestinian statehood". Journal of Ethnic and Migration Studies, vol. 44, no. 8, 2018, pp. 1289-1308, doi:10.1080/1369183X.2017.1354158.

Koinova, Maria. "How refugee diasporas respond to trauma". Current History, vol. 115, 2016, pp. 322-324, doi:10.1525/curh.2016.115.784.322.

Koinova, Maria and Dzeneta Karabegovic. "Causal mechanisms in diaspora mobilizations to transitional justice". Ethnic and Racial Studies, vol. 42, no. 11, 2019, pp. 1809-1829, https://doi.org/10.1080/01419870.2019.1624802.

Lacroix, Thomas, and Elena Fiddian-Qasmiyeh. "Refugee and diaspora memories: The politics of remembering and forgetting". Journal of Intercultural Studies, vol. 34, no. 6, 2013, pp. 684-696, https://doi.org/10.1080/07256868.2013.846893.

Laing, Nyasha. Colombia's Truth Commission prepares to embark on the extraterritorial truth-telling process. 2018, www.ictj.org/news/colombia $\% \mathrm{E} 2 \% 80 \% 99$ s-truth-comm ission-prepares-embark-extraterritorial-truth-telling-process. Accessed 14 February 2021.

Lida, Clara Eugenia, Horacio Gutiérrez Crespo, and Pablo Yankelevich. Argentina, 1976: Estudios en torno al golpe de estado. México, El Colegio de México, 2007.

Lutz, Ellen, and Kathryn Sikkink. "The justice cascade: The evolution and impact of foreign human rights trials in Latin America". Chicago Journal of International Law, vol. 2, no. 1, art. 3, 2001, https://chicagounbound.uchicago.edu/cjil/vol2/iss1/ 3. Accessed 14 February 2021.

Martínez Leguízamo, Jeisson Oswaldo. "El exilio colombiano en España: Los diálogos de paz, un antes y un después". Estudios, vol. 38, 2017, pp. 105-121, https://dia Inet.unirioja.es/servlet/articulo?codigo=6237916. Accessed 15 February 2021.

McDowell, Christopher. "Les Tamouls en Suisse. L'émergence d'une communauté post-asilaire?”. Hommes \& Migrations, vol. 3, no. 1291, 2011, pp. 104-115, https:// doi.org/10.4000/hommesmigrations.685.

McEvoy, Kieran, and Lorna McGregor, editors. Transitional justice from below: Grassroots activism and the struggle for change. Oxford, Hart Publishing, 2008.

Orjuela, Camilla. "Distant warriors, distant peace workers? Multiple diaspora roles in Sri Lanka's violent conflict". Global Networks, vol. 8, no. 4, 2008, pp. 436-452, doi:10.1111/j.1471-0374.2008.00233.x.

Orjuela, Camilla. "Mobilising diasporas for justice: Opportunity structures and the presencing of a violent past". Journal of Ethnic and Migration Studies, vol. 44, no. 8, 2018, pp. 1357-1373, doi:10.1080/1369183X.2017.1354163.

Pagina 12. El exilio como otra violación a los derechos humanos de la dictadura. 2006, www.pagina12.com.ar/diario/elpais/1-68935-2006-06-24.html. Accessed 14 February 2021.

Rauschenbach, Mina, Stephan Parmentier, and Maarten Van Craen. "Towards social restoration in Bosnia and Herzegovina: Exploring the place of symbolic forms of transitional justice". Healing and Peacebuilding After War. Transforming Trauma in Bosnia and Herzegovina, edited by Julianne Funk, Nancy Good and Marie Berry, Studies in Peace and Conflict Resolution series, Abingdon, Routledge, 2020, pp. 167-188, https://doi.org/10.4324/9780429397745. 
Riaño Alcalá, Pilar, and Maria Victoria Uribe. "Constructing memory amidst war: The historical memory group of Colombia". International Journal of Transitional Justice, vol. 10, no. 1, 2016, pp. 6-24, https://doi.org/10.1093/ijtj/ijv036.

Roht-Arriaza, Naomi. The Pinochet effect: Transnational justice in the age of human rights. Philadelphia, University of Pennsylvania, 2005.

Schultz-Kraft, Markus. Colombia's quest for historic memory and peacebuilding. 2017, www.oxfordresearchgroup.org.uk/blog/colombias-quest-for-historic-memory-and-p eacebuilding. Accessed 14 December 2020.

Sikkink, Kathryn. "The Age of Accountability: The global rise of individual criminal accountability". Amnesty in the Age of Human Rights Accountability: Comparative and international perspectives, edited by Leigh Payne and Francesca Lessa, New York, Cambridge University Press, 2012, pp. 19-41.

Stokke, Esppen, and Eric Wiebelhaus-Brahm. "Syrian diaspora mobilization: Vertical coordination, patronage relations, and the challenges of fragmentation in the pursuit of transitional justice". Ethnic and Racial Studies, vol. 42, no. 11, 2019, pp. 1930-1949, https://doi.org/10.1080/01419870.2019.1572909.

Swisspeace. Participation of the diaspora in the Colombian Truth Commission. 2019, https://koff.swisspeace.ch/fileadmin/user_upload/JLPM_CaseStudyColombia.pdf. Accessed 15 December 2020.

Tamayo Gomez, Camilo. "Victims' collective memory and transitional justice in postconflict Colombia: The case of the March of Light". Memory Studies, 2019, pp. 114, https://doi.org/10.1177/1750698019882055.

Teodora, Anca-Teodora, and Serban-Oprescu Oprescu. "From exile to diaspora and from national to transnational binds under the driving forces of globalization." Journal of International Studies, vol. 6, no. 1, 2013, pp. 96-102, doi:10.14254/20718330.2013/6-1/9.

Van Hear, Nicholas, and Giulia Liberatore. "Shifting forms of diaspora engagement among the Sri Lankan Tamil diaspora”. Diasporas reimagined: Spaces, practices and belonging, edited by Nando Sigona, Alan Gamlen, Giulia Liberatore and Hélène Neveu Kringelbach, Oxford, Oxford Diasporas Programme, 2015, pp. 211-216.

Wiebelhaus-Brahm, Eric. "Exploring variation in diasporas' engagement with transitional justice processes". Journal of Peacebuilding \& Development, vol. 11, no. 3, 2016, pp. 23-36, https://doi.org/10.1080/15423166.2016.1226933.

Yankelevich, Pablo. "Exilio y dictadura," in Argentina, 1976: Estudios en torno al golpe de Estado, edited by Clara Lida, Crespo Horacio and Yankelevich Pablo, Mexico, El Colegio de México, 2017, pp. 205-231.

Young, Laura, and Rosalyn Park. "Engaging diasporas in truth commissions: Lessons from the Liberia Truth and Reconciliation Commission diaspora project". International Journal of Transitional Justice, vol. 3, no. 3, 2009, pp. 341-361, http s://doi.org/10.1093/ijtj/ijp021. 


\title{
9 Rural women and their access to the law
}

\section{Gendering the promise of post-war justice}

\author{
Neloufer de Mel and Danushka Medawatte
}

\section{Introduction}

At the heart of Sri Lanka's nearly three-decade-long civil war (1983-2009) between the Sri Lankan state's armed forces and the Liberation Tigers of Tamil Eelam (LTTE) over the formation of a separate state of Tamil Eelam, were women with a variety of experiences of the war. Some were combatants, administrative and nursing officers in the LTTE's "Birds of Freedom" women's military wing or the Sri Lanka army's Women's Corps. Others were part of the LTTE's elite "Black Tiger" suicide squad. Numerically more significant, however, are the women of Tamil, Muslim and Sinhala ethnicity who survived, bearing the brunt of the war and its aftermath, as war widows, of whom there are an estimated 89,000 (Witting et al. 2016). In the former war zones of the north and east, many Tamil and Muslim women are also heads of households where livelihoods have been destroyed by the war (International Crisis Group 2017). They are also victim-survivors of conflictrelated domestic and sexual violence, mothers, wives or sisters of family members who were forcibly disappeared, and caregivers to those disabled in the war if not disabled themselves. Women living in these areas as well as in the contiguous border villages also face multiple internal displacements an estimated $80 \%$ of the displaced population were women (Satkunanathan 2018). The pervasive militarization of these areas has also meant restricted mobility and insecurity for women (de Mel 2017; Satkunanathan 2018). As a result of these experiences, women are also at the forefront of calls for transitional justice and accountability for war crimes, particularly in the north and east, through membership of associations such as Families of the Disappeared, Women's Action Network, Maatram, Affected Women's Forum, Suriya Women's Development Centre and the Trincomalee Women's Network, to name but a few.

Sri Lanka's justice system has, by and large, failed these women. It is plagued with issues that deter them from accessing it freely. Distance to courts of law, poor public transportation particularly in rural areas, low levels of legal literacy and high legal costs obstruct access to justice in general for both men and women (Jayasundere and Valters 2014). Women face additional barriers, such as less access to information, greater restrictions to

DOI: $10.4324 / 9781003167280-12$ 
mobility and cultural attitudes that deter them from the judicial process (Jayasundere and Valters 2014). Inadequate gender mainstreaming within the law has resulted, moreover, in judicial bias against women (evident in the misogynist stereotypes contained in legislative enactments) ${ }^{1}$ and the consideration of women as unreliable witnesses in evidence procedures (Abeywardena 2016, pp. 37-44; Fonseka and Schulz 2018; de Mel and Samararatne 2017; Medawatte 2020; Centre for Equality and Justice 2018). These prejudices impact adversely on principles of equality and equity supposedly at the heart of the law. As such, they also have implications for the execution of transitional justice in Sri Lanka.

In relation to war-related harm, there have been only a few prosecutions to date, whether for conflict-related sexual violence, such as the Krishanthi Kumaraswamy and Vishvamadhu cases, ${ }^{2}$ or for enforced disappearances. ${ }^{3}$ These cases navigate/d a highly politicized context in which political interference, from the gathering of evidence at police stations onwards, is commonplace and a culture of impunity is entrenched (Pinto-Jayawardena and Guthrie 2016; Pinto-Jayawardena and Anantharajah 2016). Successful prosecutions, such as in the Krishanthi Kumaraswamy case, were reliant on political will at the highest levels of the executive and the military. ${ }^{4}$ In such contexts but also more generally, in order to establish their autonomy, courts of law establish maze-like procedures. These procedural intricacies favour those who can afford good legal counsel, while those without such resources are often stumped, constituting "a source of new imbalances" (Galanter 2002). All of the above in the Sri Lankan context has resulted, particularly for poor, rural war-affected women, in a deterioration of trust in formal institutions of justice. In this environment, their reliance on other frameworks of justice play an important role when seeking redress for harms.

\section{Understandings of justice in a border village}

The data for this chapter is drawn from a rural border village in the former war zone of the North Central Province of Sri Lanka. The term "border village" denotes a village situated at the outskirts of a conflict zone, which makes its residents and property vulnerable to direct attacks or indirect harm resulting from the military incursions of the parties to the conflict. ${ }^{5}$ Its income is derived from agriculture and the Civil Defence Force (CDF) to which many of its men belong. ${ }^{6}$

The village suffered a horrific bombing attack during the war in which many people, including children, died. As a small, endogamous village, everyone lost a relative. A young woman's impression on seeing the bodies laid out in the village school hall was apt:

It was like seeing people we know at some kind of function ... that was how the bodies were also kept. That is to say, every face we saw, we knew, recognized ... that day was an event that I will never forget. ${ }^{7}$ 
Apart from the bombing, following the abduction of two villagers by an enemy group in the 1990s, about 100 families from this village had also spent two long spells in refugee camps, one of which lasted nearly six years. ${ }^{8}$ On returning to the village when it was safer, the villagers spent nights in makeshift shelters in the forest to avoid enemy detection. ${ }^{9}$ They also spoke of intergenerational harm and of disrupted education. ${ }^{10}$ We were also told that many youngsters in the village were addicted to drugs, due to a sense of stagnation and hopelessness. ${ }^{11}$ More than a decade after the bombing, its narration continued to evoke powerful memories of loss.

The villagers' narratives force a re-examination of a common assumption that in such contexts anger and resentment against perpetrators of violence is the default norm - a conjecture also informed by an adversarial legal system. What we actually found were dissenting memories, and a departure from the victor's perspective, indicative, perhaps, of the rural peripherality of their lives - even though all the women were Sinhala Buddhists and, as such, beneficiaries of the Sri Lankan state's emphasis of and support for Sinhala Buddhism (see Chapter 4 in this volume). For them, the war was ambient but not the only orientation point or route to the present. Many villagers articulated a deeper sense of injustice at how the state had failed to provide them with title deeds to the lands they had been forced to abandon during the war, or at the re-demarcation of forest land undertaken by the Forest Department which threatened their areas of cultivations. As noted by a woman at a focus group discussion (FGD):

When speaking about the war, it has been ... this is 2019, right? Yes, it's been ten years since the end of the war. These ten years have been enough time for the government to restore the people who were affected back to their normal life. That has not happened in our village. ${ }^{12}$

Clearly, no development drives have targeted the village. Its only educational institution is a primary school. The prosperity in the south of the country, where a majority of Sinhalese live, is missing - evident of how "large parts of the rural hinterland, further away from Colombo, had little to show for it, [with] many areas ... only marginally better off than the war-torn districts of the north and east that they border" (Venugopal 2018). In this context of precarity, the villagers insisted on being in the moment, and not only in the past. They subtly resist a politics of the "duty to remember" the war. In the interviews the women came across as having a pragmatic, open-ended relationship with history, refusing to ransack the past for political or ethnonationalist gain (Eng and Kazanjian 2003; Judt in Rieff 2016, p. 80). They did not speak ill of Tamils and some noted their traditional interactions, as a border village, with this community although these connections have now been lost. ${ }^{13}$ They did not abandon the idea of criminal justice for the wartime harms they experienced. But they had a pragmatic approach to justice, which emerged from their recognition that the legal system was stacked 
against them. From a Buddhist perspective they also noted that hatred (vairaya), which one risks when remembering injustice, is harmful. When asked for their responses to post-war justice claims, a woman declared "apoapita vairaya epa" (Oh no! We don't want hatred), which also pointed to how she understood our question on justice as being, first and foremost, about a retributive system of criminal justice.

That respondent was Leelawathi (pseudonym). To date, she is the only person from the village to be summoned to a court of law regarding a crime committed during the war - in this case the abduction and murder of her husband. Leelawathi's narrative is instructive for understanding how the weight of the law, which promises to act "in the best interests" of everyone involved (Motha 2018), bears down on rural women. In the face of Leelawathi's alienation from the law, her story also marks the transformative potential of local cultural and religious beliefs. She draws on these beliefs to remember the past in more agentive ways and to open a pathway to an ultimate justice over which she has more control. Her decisions regarding postwar justice illuminate the fault lines that will occur if transitional justice maps itself onto existing legal procedures of criminal accountability. They also invite us to reappraise the relationship between the law and the sentiment dubbed "belief in a just world".

\section{The law's authority and belief in a just world (BJW)}

Citing a wide body of literature, Rachel Fasel and Dario Spini (2014) note that "belief in a just world" enables people to confront their physical and social environments as though they were stable and orderly, commit to longterm personal goals and derive life satisfaction. Even when victimization is systematic as in prolonged wars, this belief can enable greater resilience and coping (p. 195). In a context such as post-war Sri Lanka, if belief in a just world is crucial for resilience and recovery from war, what does access to the law for war crimes mean for rural women who may hold different understandings of justice? Belief in a just world is neither a simple nor a homogenous category of beliefs. Sutton and Winnard (2007), citing the work of Lipkus et al. (1996), emphasize a distinction between belief in a just world in relation to self (the understanding that the world is fair to oneself), which leads to motivation and confidence in the achievement of life goals, and belief in a just world in relation to others (the understanding that the world is fair to others). The latter can lead to prejudice and even a desire for revenge against others, but also to mitigation of threats to oneself. Upholding a belief in a just world typically requires, therefore, constant effort. Victims do so by either denying or minimizing their hurts, by understanding harm as inevitable or amendable, or by seeing themselves (in a self-accusatory move) as the cause of the harm (Frankenberg 2014; Kaplan 2012).

Each of these positions is evident in Leelawathi's narrative. What were her expectations towards the law as justice, and towards the legal process for 
vindicating her rights as a war victim-survivor and adjudicating culpability for the abduction and murder of her husband? Summoned to a High Court for a hearing on the case, she did not comply. Her response to the law was shaped by the generally felt disillusionment with law enforcement authorities. The women spoke, for instance, about police prejudice against them not necessarily because of their gender but because they were "uneducated and poor". They also noted that they would only approach the court, if at all, as a collective group and not as individuals. For them, Heaven would be a place where they were treated with dignity and respect by authority figures. ${ }^{14}$ Leelawathi spoke, additionally, of being watched by the "enemy" and the fear of being harmed while at court, rendering her children bereft again. She thereby flagged witness protection as a crucial condition for accessing formal justice.

Eventually Leelawathi did go to court, but not before the law's authority bore down on her in the form of a police threat of a warrant against her, perhaps for contempt of court. ${ }^{15}$ Apart from this intimidating and enforced start, her entire experience at the High Court was one of bewilderment. She related how she encountered "a well-dressed Tamil man with a flower in his ear" and three or four other Tamil men at the court gates who frightened her, prompting her to hide. This court is in the vicinity of a Hindu kovil (temple) from which it is not uncommon for men (particularly in the north and east) to come out after a puja (ceremonial worship) wearing a flower in their ear. ${ }^{16}$ For Leelawathi, a resident of a traditional Sinhala Buddhist village, this encounter with a strange man, queered by his flower, was a site of incomprehensible cultural difference. As in Kafka's short story "Before the law" (whereby, like the supplicant at the gate in the story, Leelawathi is also a petitioner from the countryside) these men at the gate of the law appear to her as an intimidating hindrance to justice. Inside the court it is no better. Only her name, that of her husband and the date on which he disappeared are asked and confirmed in Sinhala. For the rest, the charges are read out in Tamil, a language she does not understand. No translation is offered or provided by the court. ${ }^{17}$ The court's failure to abide by its constitutional mandate of upholding the language rights of all citizens (Article 18 of the 1978 Constitution) positions her as an abject subject before the law.

The women's statement that they would not go to court alone was borne out by Soma (pseudonym) who accompanied Leelawathi to court. Soma's attitude to justice was markedly different to that of Leelawathi: she spoke a language of rights and resistance and stated that the villagers had no option but to protest, as the authorities and the media had failed to satisfy their demands for justice. Soma also offered an alternative interpretation to Leelawathi's conduct in court. She recalled:

In the witness box she [Leelawathi] said "I forgive. I do not ask for compensation. It can't be calculated". The judge didn't speak but he appeared to nod and approve of her statement. I was wondering whether the judge doesn't understand Sinhala. Did he not want to appreciate her 
when she smiled and forgave? I also wondered whether he was uppish because of his position.

Even though Soma intuited that the judge approved of Leelawathi's stance, his failure to verbalize his approval had left her confused. Leelawathi, on the other hand, was clear that she did not forgive the accused, although she did voice empathy for him. She stated:

I don't have hatred towards them. I will never litigate either. I will not do anything unfair by them. This must be a sin I committed in a past life. If not, if he committed it in this life, he must take responsibility for it, for like your shadow that comes behind you, you must take responsibility for your actions. I am removing this from the root itself. I will never hate this person.

Locating her own victimhood within the laws of karma, Leelawathi decided to walk away from court and avoid further involvement in the case. While information on how her case concluded is unknown, what is important to note here is that, in her rebuff of the court, she declines to be drawn back to the law on its terms. Instead, she turns to an alternative system of understanding within Buddhism without the antagonism of accusation and retribution that the law requires. Importantly, turning her back on the law was neither about forgiveness (misread as such by Soma) nor the forgetting demanded by political elites in favour of "moving on". Rather, it signified a belief in an ultimate justice - like a shadow that eventually catches up with a culprit - that keeps to a different temporality than the law, because it need not coincide with one's particular lifetime. This belief in ultimate justice was recognized by Fasel and Spini (2014) as an important coping mechanism where war related victimization was systematic. Citing Maes (1998), they noted:

When victimisation becomes a nearly ubiquitous phenomenon, as in Kosovo, people may come to believe in ultimate justice: even if a situation is unjust at present, justice will be re-established sooner or later (sometimes only after a person's lifetime). Belief in ultimate justice is associated with positive impressions of the victim, whereas belief in immanent justice (the tendency to perceive justice in the events that have already occurred) is more associated with devaluation of the victim and ascription of responsibility.

(Fasel and Spini (2014, p. 195, emphasis in the original)

Leelawathi's belief in an ultimate justice encourages her to be patient from a place that is, for her, culturally secure, true and therefore agentive. From such a place she refuses the law's certainties. She told us of the alleged perpetrator: 
He was standing in the witness box. He was young, not old at all. He was quite thin. Tall, like my son, and thin. He was wearing a checked shirt and long black pants. He had become very, very thin. He looked at my face twice or thrice as well. When the judge was reading that book, he looked at me and frowned twice or thrice. The ... court room is not big - you can see the judge very clearly ... He looked at me, and at that moment, I thought to myself that if it is some sin I have committed, then it is over in this lifetime, or if you have done something, then you have to take responsibility for it.

Leelawathi's insistence here on the provisional - "if it is some sin I have committed" or "if you have done something, then you have to take responsibility for it" marks the fact that she refuses to act "as if" - that locution which, as Stewart Motha (2018) notes, is at the heart of the law's grammar because the law presents itself as if it is grounded on Kantian reason (p. 9) and therefore as solid fact (p. 88). In other words, Leelawathi refuses to go along with the prosecution's premise that for the time being, for the purpose of the court, this tall, thin young man who looks like her son is to be charged as if he were the murderer. She told us, "I did not see what happened with my own eyes, so how do I know?" Preferring to act on uncertainty rather than on the constative "as if", she refuses the law's sleight of hand.

\section{Conclusion}

According to Felstiner et al. (1980-1), there are three stages associated with accessing the law as justice: (1) recognizing an incident as injurious; (2) attributing the injury to someone outside of oneself; and (3) requesting a remedy for the harm (cited in Young 2009). While all three steps are informed by social and cultural norms and are dependent on recognition as well as BJW, the third step is particularly reliant on external sources such as impartial courts. Where, due to a multiplicity of reasons, this third stage fails to fulfil its promise, the effect of this failure on the victim-survivor, his/her immediate family and social circle is adverse. This is viscerally heightened in situations of armed conflict where, for women, the everyday challenges of gender insecurity and discrimination are exacerbated by trauma, displacement, poverty, peripherality, fragmentation of family and community, as well as risks in witnessing.

In courts of law, the broken promise of justice means impunity and lack of accountability for various crimes: a condition which, in Sri Lanka, both predates and postdates the war (Pinto-Jayawardena and Anantharajah 2016; Fonseka and Schultz 2018; Woodworth and Fonseka 2016; Dancy and Wiebelhaus-Brahm 2019). When the law fails victims-survivors, they resort or return to BJW to mitigate what is injurious in their physical and social environments. As the women's narratives reflect, however, there is no single approach to the law and/or justice. While for many of them law enforcement 
has shown its limits by failing to protect their dignity, Soma, for instance, kept her faith in the legal arena as an important site of "protest for justice for what they lost". Her approach is resonant with the demands of many Tamil women in the north and east for accountability through the courts (inclusive of international judges) for enforced disappearances (Amnesty International 2017; de Mel and Kodikara 2018). Leelawathi's rejection of the law, on the other hand, challenged the idea of requesting a remedy through the courts altogether, and moved it towards a place of internal transformation within her control. Where the court was a theatre of bewilderment and fear, her route took an alternative inward journey, to a place Ratna Kapur (2018) would characterize as holding other "vocabularies of freedom" which challenge the "fishbowl" of liberal human rights.

Critiques of liberal human rights are all the more important as these rights are central to transitional justice doctrine (Posner and Vermeule, cited in Webber 2012). Kapur does not dismiss the necessity of rights. Her argument, rather, is that

The notion that divergent understandings of freedom have always existed outside of the liberal and neoliberal imaginaries and related market terms is either barely considered by those who shape, support and implement the rights regime, or considered inherently alien and therefore irrelevant to the recursive ideological currents within the fishbowl.

(Kapur, 2018, p. 1).

This is why, even when transitional justice has accommodated local methodologies of justice as in the gacaca courts of Rwanda or the Special Court in Sierra Leone, the results have been mixed. Coerced participation and the footprint of stern post-conflict states with their own versions of reconciliation apart, these experiments have also been marred by a tension in the imposition of international frameworks which sit uneasily with local practices and expectations (Thomson and Nagy 2010, pp. 14-15, 20; Kelsall 2009; Friedman 2017, p. 384).

While we were interviewing her, Leelawathi left apologetically, stating that she had been called for a kiri dane (an almsgiving where women "of good character" play a dominant role) organized by a family in the village. They were unable to start without her. Where she had been unable to be agentive before the law, in the village she had forged for herself a role of belonging and leadership through her spirituality. Nowhere in her narrative did she refuse the necessity for justice or ask that the perpetrator be pardoned. It is just that her sense of justice transcended retribution, particularly in a context of doubt, given that the abductions took place in the forest, and the killings elsewhere, without village witnesses. She also noted that the accused produced at court may have been too young to commit the crime. Uncomfortable not only with court procedures but also with the prosecution's assumptions, she turned her back on the law because it was at odds with the kind of justice and closure she required. 
What are the implications of Leelawathi's trajectory for understanding the challenges of criminal accountability in the context of war? This is an important question for transitional justice in Sri Lanka. While her retreat from the law is an individual choice, other war-affected women continue to look to the courts for justice. A transformative justice would necessarily ensure full and equitable access for all women to the law in the first place. But beyond this, it would also have to accept that criminal justice as currently provided by the law is limited in both its substantive and procedural aspects. A transformative approach would, then, carefully but necessarily endorse a system that accepts a range of justice procedures and outcomes. To be fair, transitional justice does attempt this in its four pillars of criminal accountability, reparation, truth-telling and institutional reform, designed to enable different registers and arrangements of justice. Paul Gready (2011, p. 5) argues, moreover, of its "shift in ethos from substitution (choosing one mechanism over another ... ) to complementarity". Yet a hierarchy which values the accountability pillar over the others still persists (International Center for Transitional Justice n.d.), ${ }^{18}$ especially where, as in Sri Lanka, accountability has been overlooked. Where even in these limited circumstances, formal legal justice remains the primary site of adjudicating criminal accountability, Leelawathi's discomfort with its dualism and authoritativeness calls for amending the law in a manner that frees, without prejudice or dismissal, the witness who is not a suspect from conforming to the pressures of adversariality and retribution. This does not mean giving up on the goal of accountability. Rather, it requires states to redouble their efforts at finding other sources of evidence, thereby disbursing evidentiary responsibility beyond the witness. This is especially important for preventing the state from adopting the easier route of dropping a case altogether for lack of witnesses, particularly when the accused is a favoured party. Revising legislation and evidence procedures in this manner goes beyond fixing gaps in implementation to re-evaluate assumptions at the heart of the law itself. It also means instantiating an ecology of justice in which the diverse experiences and choices of war-affected women in particular, with their different understandings of justice, find acceptance.

\section{Notes}

1 See for instance, Section 8 - Matrimonial Rights and Inheritance (Jaffna) Ordinance No. 1 of 1911 as amended; Section 3 Vagrants Ordinance No. 4 of 1881 as amended; Section 40 of Buddhist Temporalities Ordinance No 19 of 1931 as amended; and Sections 27 and 28 of Marriage and Divorce (Muslim) Act No. 13 of 1951 as amended.

2 The gang rape and murder of Krishanthy Kumaraswamy, a schoolgirl, and the murder of her mother and brother, and another villager who was among the search party occurred in 1996. The accused were military officers and one Reserve Constable manning the Chemmuni Checkpoint at which Krishanthi had been detained while returning home after sitting the Advanced Level Examination. The 


\section{Neloufer de Mel and Danushka Medawatte}

accused were produced before a three-member High Court Bench in 1997. The three judges issued three separate judgments which were later challenged at the Supreme Court as being evidence of lack of concurrence and so were used by the accused-appellants for a trial de novo. However, the Supreme Court (S.C Appeal No. 2/2002) determined the Trial at Bar decision valid as all the judges had arrived at the same decision, albeit through diverse reasoning processes. The Vishvamadhu case is for the gang rape in 2010 (after the war ended) of a 27year-old woman known in the legal record as 'Vishvamadhu' (the locus of the crime) and the sexual abuse of another woman. At the Trial at Bar (case number HC1569/2012 in Jaffna High Court) four Sri Lanka army personnel of the 572nd Brigade were found guilty and sentenced to rigorous imprisonment for up to 30 years. At an appeal on the basis that there were flaws in the identification of the accused-appellants, the Court of Appeal set aside the initial conviction and discharged the men on 10 October 2019. This acquittal has been challenged by Vishvamadhu and her case is ongoing.

3 One such bench at the Permanent Trial at Bar of the Colombo High Court was appointed in February 2020 to hear the abduction and disappearance of Prageeth Ekneligoda allegedly by Sri Lanka army men in 2010. Ekneligoda was a journalist. The other is on 11 young men allegedly abducted and disappeared by naval personnel in and around Colombo in 2008. Fourteen navy officers have been implicated in the crime with ransom as an alleged motive. However, both cases remain unresolved and open pending more evidence. Decades after the crimes were committed no perpetrators have yet been brought to justice.

4 Interview with Prashanthi Mahindraratne, prosecutor of the Krishanthi Kumaraswamy case. Colombo, November 2020.

5 Data is drawn from the Pluralistic Memories Project (PMP) 2015; Women, Trauma and Peacebuilding (WTP) project, 2018, and the GCRF Gender Justice and Security Hub project FGDs, 2019. Informed consent was obtained from all participants.

6 The Civil Defence Force is akin to the Home Guards and is paramilitary by nature. It was established by the Sri Lanka government under the Mobilization and Supplementary Forces Act No. 40 of 1985. It functions under the Ministry of Defence, and during the war members of the CDF were tasked with the protection of border villages. CDF men are drawn primarily from such villages and alternate between agricultural activity and defence.

7 PMP interview 16, 2015.

8 PMP interview 18, 2015; WTP respondent 1, KPI 12018.

9 WTP KPI 1 2018; PMP interview 17, 2015.

10 WTP KPI 1, 2018; PMP interview 17, 2015.

11 WTP respondent 1, KPI1, 2018.

12 GCRF interview participant, August 2019.

13 The village has had a long history of interaction with Tamils who have either passed through it on their way to the east, taken cattle and carts through the forest skirting the village, or bought cow dung from the villagers. PMP interviews 17 and 18, 2015.

14 GCRF FGD, August 2019.

15 The threat of a "warrant" is conveyed to Leelawathi by the local police force. Leelawathi, interview, August 2019.

16 Interview with a human rights lawyer who practises in the north and east, August 2019.

17 This is a common experience for Tamil speakers who encounter, on a daily basis, the dominance of the Sinhala language, including in courts of law.

18 In an introduction to transitional justice, the ICTJ states, for instance, that " $\mathrm{t}]$ ransitional justice is rooted in accountability and redress for victims. It recognizes 
their dignity as citizens and as human beings. Ignoring massive abuses is an easy way out but it destroys the values on which any decent society can be built".

\section{Acknowledgements}

This chapter draws on data from several research projects: (a) the GCRF Gender, Justice and Security Research Hub's project on "The politics and potentialities of transformative justice in Sri Lanka: Gender security and justice amidst institutional crisis", (b) the Pluralistic Memories Project led by the University of Lausanne, Switzerland; and (c) the Women, Trauma and Peacebuilding project led by the University of Uppsala, Sweden, with collaboration from the University of Colombo, Sri Lanka. Both authors are co-investigators on the first project, while the first author was a scientific advisor and co-investigator on the second and third projects, respectively. The authors are grateful to the research teams of each of these projects and to the University of Colombo. Particular thanks are due to Sandani Yapa Abeywardena and Ranitha Gnanaraj for their research assistance on the GCRF Gender, Justice and Security Hub project, and to Chulani Kodikara, Ramila Usoof, Briony Jones and Guy Elcheroth for their very useful comments on earlier versions of this chapter.

\section{References}

Abeywardena, Sandani. "Images, myths and stereotypes: A critical discourse analysis of the construction of the 'female' in judicial pronouncements of rape in Sri Lanka”. LST Review, vol. 27, no. 341, 2016, pp. 37-44.

Amnesty International. "Sri Lanka: Refusing to Disappear. Tens of Thousands Missing: Families Demand Answers". No. ASA 37/5497/2017, Amnesty International, 2017, pp. 1-15, www.amnesty.org/download/Documents/ASA3754972017ENGLISH.PDF. Accessed 19 January 2021.

Balkin, Jack M. "The proliferation of legal truth." Harvard Journal of Law \& Public Policy, vol. 26, no. 1, 2003, pp. 5-16.

Centre for Equality and Justice. Guidelines on bias and access to justice: Addressing stigma of conflict related sexual violence survivors. Centre for Equality and Justice, 2018, pp. 1-18, www.cejsrilanka.org/wp-content/uploads/Guidelin-on-Bias.pdf. Accessed 18 August 2020.

Chandrasekaram, Visakesa. The use of confessionary evidence under the counter-terrorism laws of Sri Lanka: An interdisciplinary study. Amsterdam University Press, 2017.

Dancy, Geoff, and Eric Wiebelhaus-Brahm. "Data on criminal accountability in postcivil war societies: Implications for Sri Lanka". Sri Lanka's time to try, edited by Isabelle Lassee, South Asian Centre for Legal Studies, 2019, pp. 50-60.

de Mel, Neloufer. "Risky subjects: Militarization in postwar Sri Lanka". Women and politics of peace, edited by Rita Manchanda, SAGE, 2017, pp. 137-154.

de Mel, Neloufer, and Chulani Kodikara. "The limits of 'doing' justice: Compensation as reparation in post-war Sri Lanka". Violence and the quest for justice in South Asia, edited by Deepak Mehta and Rahul Roy, SAGE, 2018, pp. 39-70.

de Mel, Neloufer, and Dinesha Samararatne. "The law's gender: Entanglements and recursions - three stories from Sri Lanka." On Culture, vol. 3, Summer 2017, www. 


\section{Neloufer de Mel and Danushka Medawatte}

on-culture.org/journal/issue-3/de-mel-samararatne-laws-gender/. Accessed 28 May 2020.

Eng, David, and David Kazanjian. Loss. University of California Press, 2003.

Fasel, Rachel, and Dario Spini. "Shattered beliefs: How to cope when the world is not a just place?" War, community, and social change: Collective experiences in the former Yugoslavia, edited by Dario Spini, Guy Elcheroth andDinka C. Biruski, Springer, 2014, pp. 183-198.

Felstiner, William L. F., Richard L. Abel, and Austin Sarat. "The emergence and transformation of disputes: Naming, blaming, claiming". Law and Society Review, vol. 631, 1980-1.

Fonseka, Bhavani, and Ellen Schulz. Gender and transformative justice in Sri Lanka. LSE Women, Peace and Security Working Paper Series, no. 18, 2018, http://eprints. lse.ac.uk/id/eprint/104047. Accessed 13 January 2021.

Frankenberg, Günter. "Human rights and the belief in a just world". International Journal of Constitutional Law, vol. 12, no. 1, 2014, pp. 35-60. doi:10.1093/icon/ mot068.

Friedman, Rebekka. "Transitional justice, popular participation and civil society: Lessons from Sierra Leone and Peru”. Transitional justice in Sri Lanka: Moving beyond promises, edited by Bhavani Fonseka, Center for Policy Alternatives, 2017.

Galanter, Marc. "Righting old wrongs". Breaking the cycles of hatred: Memory, law, and repair, edited by Martha Minow, Princeton University Press, 2002, pp. 107-131.

Gready, Paul. The era of transitional justice: The aftermath of the Truth and Reconciliation Commission in South Africa and beyond. Routledge, 2011.

International Center for Transitional Justice. What is transitional justice?, www.ictj. org/about/transitional-justice. Accessed 21 January 2021.

International Crisis Group. Sri Lanka's conflict-affected women: Dealing with the legacy of war. Asia report no. 289. Brussels, International Crisis Group, 2017, pp. 1-35, www.crisisgroup.org/asia/south-asia/sri-lanka/289-sri-lankas-conflict-affectedwomen-dealing-legacy-war. Accessed 8 January 2021.

Jayasundere, Ramani, and Craig Valters. Women's experiences of local justice: Community mediation in Sri Lanka. JSRP Paper 10. London, The Justice and Security Research Programme and the Asia Foundation, 2014, pp. 1-29, http://eprints.lse.ac. uk/56350/1/JSRP_Paper10_Women's_experiences_of_local_justice_Jayasunders_Va 1ters_2014.pdf. Accessed 26 July 2021.

Kaplan, Hasan. "Belief in a just world, religiosity and victim blaming". Archive for the Psychology of Religion, vol. 34, no. 3, 2012, pp. 397-409. doi:10.1163/15736121-12341246.

Kapur, Ratna. Gender, alterity and human rights: Freedom in a fishbowl. Edward Elgar, 2018.

Kelsall, Tim. Culture under cross-examination: International justice and the Special Court for Sierra Leone. University of Cambridge Press, 2009.

Lipkus, I. M., C. Dalbert, and I. C. Siegler. "The importance of distinguishing the belief in just world for self versus for others: Implications for psychological wellbeing". Personality and Social Psychology Bulletin, vol. 22, 1996, pp. 666-677.

Maes, J. "Immanent Justice and ultimate Justice: Two ways of believing in justice". Responses to victimizations and belief in a just world, edited by L. Montada and M. J. Lerner, Plenum Press, 1998, pp. 9-40.

Medawatte, Danushka S. "Chasing tails: Establishing the right to truth, mourning, and compensation". California Western International Law Journal, vol. 46, no. 2, 2016, pp. 69-107. 
Medawatte, Danushka S. “Conflict related sexual violence: Patriarchy's bugle call”. Georgetown Journal of Gender and the Law, vol. XXI, no. 3, 2020, pp. 671-703.

Motha, Stewart. Archiving sovereignty: Law, history, violence. University of Michigan Press, 2018.

Pinto-Jayawardena, Kishali, and Kirsty Anantharajah. "A crisis of 'legal indeterminacy' and state impunity”. The search for justice: The Sri Lanka papers, edited by Kumari Jayawardena and Kishali Pinto-Jayawardena, Zubaan, 2016, pp. 36-169.

Pinto-Jayawardena, Kishali, and Jeanine Guthrie. "Introduction". The search for justice: The Sri Lanka papers, edited by Kumari Jayawardena and Kishali PintoJayawardena, Zubaan, 2016, pp. xix-lii.

Rieff, David. In praise of forgetting: Historical memory and its ironies. Yale University Press, 2016.

Satkunanathan, Ambika. "Sri Lanka: The impact of militarization on women". The Oxford handbook of gender and conflict, edited by Fionnuala Ní Aoláinet al., Oxford University Press, 2018, pp. 579-590.

Sutton, Robbie M., and Elizabeth J. Winnard. "Looking ahead through lenses of justice: The relevance of just-world beliefs to intentions and confidence in the future". British Journal of Social Psychology, vol. 46, no. 3, 2007, pp. 649-666, doi:10.1348/014466606x166220.

Thomson, Susan, and Rosemary Nagy. "Law, power and justice: What legalism fails to address in the functioning of Rwanda's gacaca courts". The International Journal of Transitional Justice, vol. 5, no. 1, 2010, pp. 11-30, doi:10.1093/ijtj/ijq024.

Venugopal, Rajesh. Nationalism, development and ethnic conflict in Sri Lanka. Cambridge University Press, 2018.

Webber, Jeremy. "Forms of transitional justice". Transitional Justice: NOMOS LI, vol. 51, 2012, pp. 98-128, www.jstor.org/stable/24220125.

Witting, Alyssa B., Jessica Lambert and Thulitha Wickrama. "War and disaster in Sri Lanka: Implications for widows' family adjustment and perception of self-efficacy in caring for one's family". International Journal of Psychology, vol. 54, no. 1, 2016, pp. 126-134, doi:10.1002/ijop.12407.

Woodworth, Anne, and Bhavani Fonseka. Accountability and reparations for victims of conflict related sexual violence in Sri Lanka. Centre for Policy Alternatives, 2016, pp. 1-32, www.cpalanka.org/wp-content/uploads/2016/07/CSV-paper-June-2016. pdf. Accessed 18 January 2021.

Young, Kathryne M. "Rights consciousness in criminal procedure: A theoretical and empirical enquiry". Access to justice, edited by Rebecca L. Sandefur, Emerald Group Publishing, 2009, pp. 67-95. 


\title{
10 Former combatants
}

\section{Assessing their reintegration ten years after the end of war}

\author{
Ramila Usoof-Thowfeek and Viyanga Gunasekera
}

\section{Introduction}

When years of fighting, hostilities and destruction that characterize intractable conflicts come to an end, many mistakenly believe that it also signifies a return to normal; a return to complete peace and the end of tensions, violence and challenges. However, examples from all over the world and many different conflicts show that this is far from the reality. Intractable conflicts leave people grieving, injured both physically and psychologically, often needing help in forging a way forward: communities that are fragmented and lacking in both resources and relationships that otherwise would have held them together (Coleman 2000). Many countries that have experienced intractable conflicts are found to have regressed economically and in other facets of development (Muggah 2005). Therefore, despite expectations and hope, it is clear that after an intractable conflict, moving forward needs careful consideration, strategizing, planning and implementation of programmes that facilitate a successful transition to a more peaceful post-war and eventually a post-conflict state.

Transitional justice is an important mechanism used when normal justice systems are inadequate for addressing war crimes and past conflict-related abuse and where communities and social relations are fractured and in need of transition to peace (Garcia-Godos and Sriram 2013). One such aspect of peacebuilding and transitional justice is the disarmament, demobilization, and reintegration of ex-combatants. For a variety of reasons such as the likelihood of recidivism, broken bonds of trust and social cohesion and the long-term goal of reconciliation, it is seen as important to have a particular focus on ex-combatants in post-conflict communities (Nilsson 2005; Berdal and Ucko 2013). Known by the acronym DDR or DDRR, the standard process pivots on three facets: (1) disarmament involving the collection and disposal of weapons; (2) demobilization entailing the discharge of combatants from armed groups; and (3) reintegration as the long-term process of integrating former combatants to civilian status, providing viable employment and placing them in their former communities (Muggah 2005; Waldorf 2013). DDR has become a central part of international peacebuilding, peacekeeping and transitional justice, as it is considered essential for

DOI: $10.4324 / 9781003167280-13$ 
stabilizing security, limiting the risks of return to violence and long-term social cohesion (Garcia-Godos and Sriram 2013).

This process is long and can be difficult because it is often not linear and sequential (Berdal and Ucko 2013). Defining and identifying combatants who take part in DDR programmes is in itself a sensitive issue especially in the context of civil wars where many combatants are forcefully recruited, or are irregular combatants, "war wives", or child combatants who may not necessarily bear arms and commit crimes but merely accompany fighting forces (Waldorf 2013). Furthermore, while DDR focuses on ex-combatants and state security, transitional justice focuses on accountability and victims, and the two processes often take parallel paths in terms of operations.

The reintegration aspect of DDR, which is a long-term process, needs to be closely linked with transitional justice processes so that it facilitates the social reintegration of ex-combatants (Waldorf 2013). Social reintegration is basically the process through which ex-combatants navigate their post-war identities and social relationships (Friedman 2018). Community life and social relationships are important components of one's psychosocial wellbeing and effective agency. In the case of ex-combatants returning to civilian communities, these steps are seen as critical in reclaiming or forming identities and belonging within the community. The deep stigmatization and reluctance on the part of the community to accept former combatants as members of their ingroups are crucial issues that DDR programmes often fail to address. Waldorf (2013) recommends employing transitional justice mechanisms such as truth commissions, local justice processes and memorialization rituals where ex-combatants are given a public space to tell their stories, apologize, undergo purification rituals or justice processes as solutions to this challenge. Such practices would help the community to individualize criminal responsibility, empathize with the other and not necessarily perceive and treat all ex-combatants as having committed war crimes. Overall, such transitional justice practices may reduce fears, resentment, stigmatization and discrimination against ex-combatants if they are given the chance to tell their stories and make amendments publicly. This, in turn, would benefit their social reintegration (pp. 72-3).

DDR programmes are also important because they allow international bodies, such as the United Nations, governments and government agencies, international and local non-governmental organizations (NGOs), to help in post-conflict peacebuilding and transitional justice processes (Muggah 2005). Although there have been about 60 such DDR processes globally, during the past three decades, which have been successful, there also have been contexts where the DDR process has been more difficult and challenging. The Sri Lankan case is one such situation.

This chapter critically examines the nature of the DDR process put in place by the Sri Lankan government, its achievements, pitfalls and the state of the process more than a decade after the end of the war. The chapter first discusses DDR as a concept, transitional justice and the importance of 
meaningful reintegration of ex-combatants. Next, it focuses on the Sri Lankan context, its civil war and the implementation of DDR in an environment where the state won an overwhelming military victory over the Liberation Tigers of Tamil Eelam (LTTE). The chapter foregrounds its findings under three main sections: (1) how the state discourse around DDR and excombatants was framed; (2) how it was legitimized by handpicked academics through research; and (3) alternative findings and narratives on the experiences and challenges faced by LTTE ex-combatants and military personnel. In conclusion, the chapter discusses the need for a more transformative politics and programmes for better integration and social participation of ex-combatants in Sri Lanka.

\section{Background: Sri Lanka's war}

For 30 years, since the mid-1970s, Sri Lanka was embroiled in a civil war between the LTTE and the government's armed forces. While there is contention about the starting point of the war, many scholars agree that a longterm feeling of deprivation among the Tamil community was pivotal in the formation of the LTTE and its subsequent militancy. Certainly, the attacks perpetrated on the Tamil community in July 1983, known as Black July, was also fertile grounds for recruitment of combatants to the LTTE (Perera 2001). The war raged most severely in the Northern and Eastern Provinces. However, many other areas of the country were also susceptible to violence, characterized by sporadic attacks on government installations and suicide bombings targeting populated areas. While initially recruitment to the LTTE tended to be voluntary, in later years, as the fighting intensified, the LTTE instantiated forced recruitment as a means of bolstering its forces and dwindling ranks. Nevertheless, at the end of the war in 2009, it was estimated that 25,000 combatants, including those who played more civilian/administrative roles, were enlisted by the LTTE (Richards 2014). This also included children, many of them forcibly recruited, and women cadres, some of whom played a central role in combat, bearing higher military ranks and participating in high-profile missions - especially suicide bombing missions (Friedman 2018). On the other hand, it is estimated that during the 30 -year war over 300,000 soldiers were recruited to the government's armed forces (A correspondent 2012). The majority of these recruits tended to be from rural areas and lower socio-economic circumstances. Collectively, therefore, the number of former combatants in Sri Lanka who have war exposure run into the hundreds of thousands. Despite this large number of people with direct involvement in military activities on both sides, the focus has been very much on the DDR process involving former LTTE combatants rather than soldiers in the government's armed forces. This was largely the result of the circumstances under which the civil war ended.

In 2009, the Sri Lankan government's armed forces announced the defeat of the LTTE. At the end of the war, it was reported that between 10,000- 
12,000 LTTE combatants (depending on different sources) had either surrendered or had been taken into custody by the Sri Lanka military (Roberts 2011; Antonovskaya 2015; Gunasekera and Pathiraja 2019). Additionally, much of the LTTE's weaponry was captured during the final push by the Sri Lanka military.

As a means of moving forward on transitional justice and dealing with the large number of LTTE combatants in its custody immediately after the war, the Sri Lankan government embarked on a process ostensibly geared towards rehabilitating and reintegrating these ex-combatants. Given the nature of its unilateral war victory, the disarmament and demobilization phases of the DDR were already redundant. Rehabilitation and reintegration became a focus only in relation to ex-LTTE combatants and not the state's military personnel (Hettiarachchi 2013, pp. 106-7; Dharmawardhane 2013, p. 28). DDR, which is generally designed as a consensual process between warring parties and a precondition to a ceasefire or peace agreement (Subedi 2013; Antonovskaya 2015), took a different form in Sri Lanka, however, in the context of the state's unilateral victory over the LTTE, whereby the defeated side did not have a say in the process.

Ten years on, the process of rehabilitation and reintegration that the Sri Lankan government embarked upon still raises questions. Despite the fact that its formal phase has more or less come to an end, as we will discuss later in the chapter, many ex-combatants who went through the process continue to struggle, hidden behind new political realities. We will also analyse the situation of the Sri Lanka army soldiers who were not included in the rehabilitation and reintegration process of the DDR programme.

\section{The state narrative of the DDR process}

Just as the details around the final stage of the war have been a tightly guarded secret, so too were the details about the rehabilitation process that ex-LTTE combatants underwent. The rehabilitation process was completely under the control of the Sri Lankan government forces, especially the Sri Lanka Army. The immediate aftermath of the war also saw a complete ban on any other party, whether local and international NGOs, researchers and scholars, or advocacy groups with contacts with the war-affected population in the newly "liberated" provinces. The government at the time carefully crafted a narrative in which any organization that had expressed sympathy or concern for the Tamil community in the North and East were labelled as "anti-Sri Lanka" and "pro-LTTE". This was not surprising given the antagonism of the government to many international and local advocacy and NGOs (Gomez 2018; Höglund and Orjuela 2013; Webber et al. 2018). It was the case, however, that a small select team of psychologists and academics were given access to the rehabilitees (Webber et al. 2018). However, ten years after the ending of the war, ex-combatants who underwent the rehabilitation process are still reluctant to talk about their experiences. Trying to 
understand what ex-LTTE combatants underwent during rehabilitation requires, therefore, a piecing together of information from many different sources. This is important because it provides a basis for a better understanding of the rehabilitation programme in Sri Lanka and of ex-combatants as "forgotten actors".

According to the Bureau of the Commissioner General of Rehabilitation (BCGR), the military arm in charge of the rehabilitation process, it was formalized in 2006 through a gazette notification to enable ex-LTTE combatants who had surrendered, or who had been taken into custody by the Sri Lanka government armed forces, to be rehabilitated. However, given Sri Lanka's long history of ethnic strife and insurrection, the idea of rehabilitation had been in the official discourse much longer. The first occasion upon which Sri Lanka employed a rehabilitation programme was in 1971 after the defeat of the Janatha Vimukthi Peramuna (JVP) insurrection. It was not conceived as a comprehensive programme but is generally considered a success, as the JVP has evolved into a strong political movement (Hettiarachchi 2013). The current programme for the rehabilitation of ex-LTTE combatants has been set up under the Ministry of Defence, with some involvement of the Ministry of Justice, and is now vested with the Ministry of Justice, Human Rights and Legal Reform. The procedure for rehabilitation began with the categorization of the rehabilitees according to their levels of exposure and involvement, gender and whether they were adults or children. Throughout its existence the commissioner of the BCGR has been a senior army officer (BCGR 2011).

The rehabilitation programme established at the end of the war stood on six pillars (Webber et al. 2018). These were (1) spiritual, religious and cultural rehabilitation; (2) educational rehabilitation; (3) vocational rehabilitation geared at livelihood development; (4) family, social and community rehabilitation; (5) psychological and creative therapies rehabilitation; and (6) sports and extracurricular activities.

\section{Access to rehabilitees and research}

The final stage of the war, when fighting was at its most intense, was dubbed a "humanitarian mission" by the government. In the same vein, the DDR programme was dubbed "humanitarian mission two" (Hettiarachchi 2018). The rehabilitation of ex-LTTE combatants was legitimized and, nationally and internationally, promoted as being "based on Buddhist principles of forgiveness and compassion". The LTTE cadres were constantly described as "diehard ruthless terrorists" and "human beings whose minds were distorted", who were in need of reversing their "radicalization process" (BCGR 2011; Hettiarachchi 2014). As we will discuss later in the chapter, the Sri Lanka DDR programme was justified as a mechanism of transitional justice geared towards fostering reconciliation and social cohesion, although others have described it as a tool for strengthening the victor's security and 
governance, legitimizing social and political control of ex-combatants and silencing minority voices (Schröter 2013; Subedi 2013).

While the BCGR describes a six-pillar process, according to other sources the programme was described as a $6+1$ process, with the rehabilitation of the community added as a separate pillar (Hettiarachchi 2015). Furthermore, detailed information on the programme was available only to a hand-picked group of persons who had been granted access to the rehabilitees during the rehabilitation period. Interestingly, a number of papers written by this group describe the rehabilitation process as a success story (see Kruglanski et al. 2014; Hettiarachchi 2013, 2014, 2015, 2018; Webber et al. 2018). Their papers also include the discussion of some empirical work conducted by this team. For example, Webber et al. (2018, p. 542) describe studies conducted with the rehabilitees while they were still at the rehabilitation centres, which examined attitudinal change induced by the training. Using questionnaires (translated into, but not necessarily validated in, local languages) measuring embeddedness, extremism attitudes, deradicalization and change of status, the researchers concluded that those who completed the rehabilitation process had given up their "radical", "extremist" and "terrorist" ways (Webber et al. 2018)

In order to bolster the claim of the efficacy of the rehabilitation programme, the researchers also conducted a second, follow-up study (Webber et al. 2018, p. 562). In this study, rehabilitees who had completed the programme were compared to a sample from the community. Again, it was found that the rehabilitees were more likely to express attitudes that rejected extremism and violence. Additionally, the study also concluded that rehabilitees were more likely to have positive attitudes toward Sinhala people and the Sri Lankan government. The researchers asserted that they were not associated with the then government or the military in any way (Webber et al. 2018, p. 546). However, their findings were used to refute and question opinions that were critical of the government's handling of the immediate aftermath of the war. These studies were hence instrumental not only to defend the government's conduct in handling the Tamil community in academic discourse on the end of the war, but also in promoting the government's case in the face of international criticism. The researchers were invited to speak at different government-sponsored or government-organized forums to share their findings (Kruglanski 2012). However, questions regarding the research ethics and methodology can be raised.

For instance, the researchers do not discuss the power dynamics of the context within which their research was conducted (Kruglanski et al. 2014; Hettiarachchi 2013, 2014, 2015, 2018; Webber et al. 2018). The fact that they were allowed into highly restricted facilities would have immediately signalled to the rehabilitees that they were sanctioned by the government and the military. Therefore, given the restricted freedoms conferred on the rehabilitees, the notion of informed consent and voluntary participation becomes problematic. It is unlikely that, in this context, respondents would perceive 
that they were in a position to decline taking part in the research without fearing consequences. Overall, the unilateral victory that ended the war, and the ethos of triumphalism vs subjugation that governed the relationships between Sinhala and Tamils, between the government of Sri Lanka and the Tamil community, between the state military and the former LTTE combatants, appears to have permeated a specific reading of the context that orients the goals and conduct of the research. These issues are not addressed in their work published so far.

The rehabilitees also included children, but there is little information provided in the studies as to how standards of informed consent and voluntary participation were met in the case of these minors. Additionally, the context and the manner in which data was collected raises some methodological questions. The studies do not address how the military presence during data collection was handled. This becomes important in the context of other reports that rehabilitees were forced to complete questionnaires while at the rehabilitation centres (Roberts 2011). The likelihood that they would freely and without fear respond to the questionnaires needs to be critically examined. Therefore, the findings and the assertions made in these studies need to be read with caution.

\section{Challenges and experiences faced by former combatants and the Sri Lanka military}

In contrast, a larger number of studies have pointed to difficulties of reintegration. The success of a post-war DDR process is measured by the success of the reintegration of former combatants (Khan et al. 2018). Given the constraints of access to ex-combatants while on the rehabilitation programme, and the ethical challenges associated with this situation, many researchers approached ex-combatants only after they had been released for reintegration into the community. These studies pay careful attention to ethical concerns and security in working with such a vulnerable population (Krishnan 2012; Azmi 2015; Friedman 2018; Kabir 2018; Gunasekera and Pathiraja 2019). One particular reason for the security concerns is that many ex-combatants believed they were under continuous surveillance by the military and police.

Although ex-combatants had completed the formal rehabilitation programme stipulated by the government, the CID and army intelligence officers were believed to follow them within their communities (Roberts 2011; Azmi 2015). While the official justification for this surveillance was that it was to ensure the non-involvement of ex-combatants with groups or people that could pose a threat to the country, many ex-combatants saw this as a sign that they were not trusted by the authorities. Ironically, although the main aim of the rehabilitation programme was to ensure that they became reoriented towards the community, continued surveillance has caused their ostracism, as including them in social interactions risks bringing unwanted 
attention to the whole community. This is further compounded by the fact that family members or associates of ex-combatants have been questioned or pursued by the authorities due to missteps by an ex-combatant (Roberts 2011).

Furthermore, although the $6+1$ rehabilitation uses the term "beneficiary" to describe an ex-combatant, the terms "ex-combatant" and "ex-LTTEer" have become entrenched both in official communication and day-to-day discourse. This identity is formalized by a certificate provided to all rehabilitees, which includes information on the rehabilitation process, that they are required to carry throughout their lifetimes (Gunasekera and Pathiraja 2019). This impedes successful reintegration, as having to carry such documentation means that ex-combatants cannot expunge their past histories and move forward. Having to deal with such labels also has negative repercussions on a person's ability to secure employment. Many firms do not want to employ people with such a past for fear of attracting the scrutiny of the authorities on their businesses or organizations. Additionally, despite the LTTE having claimed to be the sole representative of the Tamil people, many Tamils have mixed feelings about the group. Therefore, people do not always trust those who associated with the LTTE (Usoof-Thowfeek 2018).

\section{Livelihood and work-related challenges}

While these reasons are associated with high rates of unemployment among ex-combatants, a shortage of viable employment opportunities further exacerbates the situation. According to the BCGR, unemployment rates have been as high as $16 \%$ among the ex-combatant group at certain times. The Northern Province in general tends to have a very high rate of unemployment, largely due to its history of under-development and exposure to the war. With the restriction on movement placed on the rehabilitees by the BCGR, ex-combatants are limited to finding work within the community (although some have been able to secure employment abroad with permission from the Bureau). Although the rehabilitation programme focused largely on the acquisition of skills such as carpentry, masonry, mechanics, information technology, etc., the work most commonly available in the Northern Province tends to be daily wage work, often centred around development projects. More recently, however, these opportunities have also become limited with southern contractors bringing their own labour force (Silva et al. 2018). Other job opportunities have been on the controversial military-run agricultural farms in the North and East. These are viewed as attempts by the Sri Lanka military to take control of the agricultural production in these provinces, in a context whereby local farmers are unable to compete with large-scale farms powered by free and/or cheap labour. Self-employment among ex-combatants has also been promoted by the government, but due to the above-mentioned reasons and the lack of entrepreneurial training, many have not been able to sustain these endeavours. This is especially true 
for child ex-combatants, who, because of their involvement in the war, lost years of education that would otherwise have prepared them for a career. As such, none of the prospects promised by the government really provided a clear career path for ex-combatants (Miriyagalla 2014).

\section{Female ex-combatants}

The situation of female ex-combatants has been of particular interest in the discourse about rehabilitation and reintegration. With very traditional gender norms still prevalent in Sri Lanka, and particularly in the Northern and Eastern Provinces, women are particularly susceptible to challenges in reintegration. For example, women associated with the LTTE and who have been in combat are seen as deviant and are therefore stigmatized and ostracized from their communities. Where women in general have found it difficult to find work, given the nature of the job market in these provinces, some female ex-combatants are also heads of households. Having to sustain themselves and their families within the narrow confines of acceptable gender roles has been quite distressing (Usoof-Thowfeek 2018). This is particularly so as the measure of successful reintegration for female ex-combatants is adopted within these narrow, conservative and traditional gender norms. For instance, marriage and starting a family are regarded as key markers of the successful reintegration of a woman (Krishnan 2012, p. 10; Martin 2017, p. 81). State- and military-sponsored mass weddings were quite common at the end of the rehabilitation processes. These were often graced by high-level politicians and military personnel, and were widely telecast over electronic media with little regard for the privacy of the rehabilitees involved. However, not all of these marriages result in "happily ever after", given the higher rates of divorce, separation and abandonment among ex-combatants (Gunasekera and Pathiraja 2019). This adds another layer of challenge to the experiences of female ex-combatants who face further stigma and ostracization when a marriage fails. But most importantly, these narrow interpretations of gender roles prevent women from imagining a future for themselves in which they have the freedom to redefine their expectations of what is possible and acceptable.

\section{Rehabilitation and reintegration within the Sri Lanka military}

While a significant body of literature has focused on the rehabilitation and reintegration of ex-LTTE combatants, the process for soldiers of the Sri Lanka military has gained little attention. The rehabilitation and reintegration of military personnel has been completely under the purview of the military. While the government has been eager to speak of the rehabilitation of the LTTE combatants, the process in relation to Sri Lankan military personnel has garnered very little attention. Most discussions on the topic have been from a purely physical well-being aspect, focused on those who have 
suffered injury and/or are disabled. This is the focus of institutions such as Ranaviru Sevana and Abhimansala. Weisdorf and Sørensen (2019) describe this focus on disability as being protective for the soldier (p. 97). They contend that, despite being disabled, it allowed soldiers to take on a certain level of heroism. However, ten years after the ending of the war these institutions are hardly ever heard of and there is little discussion about the programmes that help former military personnel. What has been continuously missing from this discussion is the question of what mechanisms should be put in place to support those who have not been disabled in fighting but who have still been directly involved in combat. For example, these soldiers are trained in the use of weaponry and some have only known a life of combat for several decades. Therefore, it is important to have some training that prepares them for civilian life, especially upon retirement and during periods of relative peace. This is particularly the case when, after the end of war, the military diversified into other ventures, such as the tourism service sector where soldiers did become involved in the management and running of hotels, but where the numbers involved in such ventures have been small.

Additionally, with the unilateral victory by the Sri Lanka armed forces in 2009 , one wonders whether maintaining the image of the army as unfaltering and undefeated also played a role in suppressing the narrative on military rehabilitation. To admit that soldiers needed help with reintegration would damage the narrative constructed about the Sri Lanka military and thereby be considered disrespectful. The result of this is that thousands of military personnel with weapons training, who directly experienced the horrors of war, have been left without the help they might need to reacclimatize to civilian roles. Certain statistics suggest indeed that help is needed: researchers have pointed to high levels of post-traumatic stress disorder and other psychological disorders among military personnel exposed to war (Fernando and Jayatunge 2013). The toll exerted on families and communities when large numbers of military personnel suffer from such psychological distress can be substantial. Additionally, there have been reports of ex-military personnel and deserters' involvement in crime. In one report, according to police statistics, military deserters were involved in $18 \%$ of crimes committed in the country (Colombage 2014). The government's strategy so far has been to announce amnesty periods periodically and once a considerable number of deserters have surrendered or have been arrested, they are discharged from the military with no programmes that prepare them for civilian life. However, this is not a far-reaching solution to help those in the military reintegrate into civilian lives during more peaceful times.

\section{Conclusion}

Ten years after the end of the war, Sri Lanka still needs to confront the reintegration needs of those who had, for several decades, fought the war. Both former military personnel attached to the Sri Lankan armed forces as 
well as those who had fought on the side of the LTTE seem to have been left behind to fight another battle. In the North and East, rehabilitees are resentful towards government and military authorities as well as their own communities because they are unable to move forward. The system has not given them the freedom to redefine themselves in relation to their current lives, make public amends and gain the acceptance and trust of their communities. Who they are today, and who they will be tomorrow is, above all, defined by their past: in some cases, a past that was chosen for them.

On the other hand, for those in the government armed forces, being disabled is the most acceptable way of having a voice in the reintegration debate. Those who have not suffered such a catastrophe have had to continue to play the role of the invincible, ever-unfaltering soldier, called upon to fulfil many different tasks - from keeping the city clean, to selling vegetables, to working in the hospitality industry and, mostly recently, preventing the spread of coronavirus disease (COVID-19). This status change cannot be easy. It is clear that if this situation is left as is, it poses a threat to future reconciliation and social cohesion, as the country attempts to move forward from a history of violence and conflict.

As much as DDR might be viewed as a next required and inevitable step in post-war scenarios, ensuring the inclusion of forgotten actors such as excombatants and state military personnel in transitional justice processes such as this is of paramount importance for meaningful reconciliation and sustainable peace. Limiting the militarization and surveillance of ex-combatants is a long-overdue first step. Ideally, government institutes, together with civil society, could then take steps to initiate a truth-telling process and provide the space to share the pluralistic memories of ex-combatants and communities, in order to seek communal forgiveness and acceptance, restore the dignity of victims, address justice concerns, help outsiders to understand the different sociocultural and political circumstances that led people to become parties to violence, or promote ritualistic penance and communal healing. Such steps would benefit not only ex-combatants and their communities but also the state by meaningfully addressing international allegations of human rights abuse, inculcating trust in national and international transitional justice and reconciliation processes, and encouraging forgotten actors to participate more proactively in peacebuilding as well as in the socio-economic and political development of the country.

\section{Reference}

A correspondent. "Notes on the military presence in Sri Lanka's Northern Province". Economic and Political Weekly, Vol. XLVII, No. 28, 2012, pp. 34-40.

Antonovskaya, Vasilina. Disarmament, demobilization and reintegration (DDR) in the context of a total victory: Elimination or evolution of the concept. The case of Sri Lanka. The Arctic University of Norway, 2015, https://munin.uit.no/bitstream/ha ndle/10037/9242/thesis.pdf?sequence $=4 \&$ isAllowed $=\mathrm{y}$. 
Azmi, Fazeeha. "I want my wings back to fly in a new sky: Stories of female ex-ltte combatants in post-war Sri Lanka". Female combatants in conflict and peace: Challenging gender in violence and post-conflict reintegration, edited by Seema Shekhawat, Palgrave Macmillan, 2015, pp. 200-215. doi:10.1057/9781137516565_13.

Berdal, Mats, and David H. Ucko. "Introduction to the DDR forum: Rethinking the reintegration of former combatants". International Peacekeeping, vol. 20, no. 3, 2013, pp. 316-320, doi:10.1080/13533312.2013.843971.

Bureau of The Commissioner General of Rehabilitation (BCGR). The Bureau of The Commissioner General of Rehabilitation. 2011, https://bcgr.gov.lk/history.php.

Coleman, Peter T. "Power and conflict". The handbook of conflict resolution: Theory and practice, edited by Morton Deutsch and Peter T. Coleman, San Francisco, Jossey-Bass, 2000, pp. 108-128.

Colombage, Dinouk. "Crime among Sri Lanka soldiers on rise". Aljazeera, 6 June 2014, www.aljazeera.com/features/2014/6/6/crime-among-sri-lanka-soldiers-on-rise.

Dharmawardhane, Iromi. "Sri Lanka's post-conflict strategy: Restorative justice for rebels and rebuilding of conflict-affected communities". Perspectives on Terrorism, vol. 7, no. 6, 2013, pp. 27-57.

Fernando, Neil J., and Ruwan M. Jayatunge. Combat related PTSD among the Sri Lankan army servicemen. 2013, Semantic Scholar, /paper/Combat-Related-PTS D-Among-The-Sri-Lankan-Army-Fernando/a257bb528418c5cf0c2a720ecaf78a9a2 245ce8a.

Friedman, Rebekka. "Remnants of a checkered past: Female LTTE and social reintegration in post-war Sri Lanka”. International Studies Quarterly, vol. 62, no. 3, 2018, pp. 632-642, doi:10.1093/isq/sqy019.

Garcia-Godos, Jemima, and Chandra Lekha Sriram. "Introduction”. Transitional justice and peacebuilding on the ground: Victims and ex-combatants, edited by Chandra Lekha Sriram, Jemima Garcia-Godos, Johanna Herman, and Olga Martin-Ortega, Routledge, 2013, pp. 1-21.

Gomez, Mario. "Keeping rights alive: Reform and reconciliation in post-war Sri Lanka". Asian Yearbook of International Law, vol. 17, 2018, pp. 117-148, doi:10.1163/9789004379718_005.

Gunasekera, Viyanga, and Kasun Pathiraja. From "combatant" to civilian": The psychosocial wellbeing of ex-combatants in Kilinochchi and Mullaitivu in Sri Lanka. Colombo, International Centre for Ethnic Studies, 2019, http://ices.lk/wp-content/ uploads/2019/12/From-Combatant.pdf.

Hettiarachchi, Malkanthi. "Rehabilitation to deradicalise detainees and inmates: A counter-terrorism strategy". Journal of Policing, Intelligence and Counter Terrorism, vol. 13, no. 2, 2018, pp. 267-283, doi:10.1080/18335330.2018.1476774.

Hettiarachchi, Malkanthi. "Sri Lanka's rehabilitation program: A new frontier in counter terrorism and counter insurgency". Prism, vol. 4, no. 2, 2013, pp. 105-121.

Hettiarachchi, Malkanthi. Sri Lanka's rehabilitation program: The humanitarian mission two. Department of Government Information, 2014, p. 51.

Hettiarachchi, Malkanthi. "Sri Lanka's rehabilitation programme: The humanitarian mission two". Terrorist rehabilitation: A new frontier in counter terrorism, edited by Rohan Gunaratna, vol. 7, Imperial College Press, 2015, pp. 103-131, doi:10.1142/ 9781783267446_0005.

Höglund, K., and C. Orjuela. "Friction and the pursuit justice in post-war Sri Lanka". Peacebuilding, Vol. 1, No. 3, 2013, pp. 300-316.

Kabir, Sarah. Voices of peace. Sarvodaya Vishva Lekha, 2018. 
Khan, Ilam, Ahmed Saeed Minhas, and Hajra Nasir Satt. "Evaluation of the postinsurgency rehabilitation program in Sri Lanka". Global Regional Review, vol. 3, no. 1, 2018, pp. 76-90, doi:10.31703/grr.2018(III-I).06.

Krishnan, Sonny Inbaraj. The transition to civilian life of teenage girls and young women ex-combatants: A case study from Batticaloa. International Centre for Ethnic Studies, 2012.

Kruglanski, Arie, Prof Arie Kruglanski USA Part01. 2012. YouTube, www.youtube. com/watch?v=1Xw4_HOOF3A\&t=197s\&ab_channel=SLArmyDirectorTraining.

Kruglanski, Arie, Michele J. Gelfand, Jocelyn J. Bélanger, Rohan Gunaratna, and Malkanthi Hettiarachchi. "De-radicalizing the Liberation Tigers of Tamil Eelam (LTTE): Some preliminary findings". Prisons, terrorism and extremism: Critical issues in management, radicalisation and reform, edited by Andrew Silke, Routledge, 2014.

Martin, Melissa. "Sri Lanka's ex-combatant rehabilitation programme: Reconstructing gendered identities". Journal of Peacebuilding \& Development, vol. 12, no. 1, 2017, pp. 79-84, doi:10.1080/15423166.2017.1281755.

Miriyagalla, Danura. "Socio-economic reintegration of former LTTE combatants in Sri Lanka: Self-employment, sustainable incomes and long-term peace". Global Change, Peace \& Security, vol. 26, no. 3, 2014, pp. 251-262, doi:10.1080/14781158.2014.953469.

Muggah, Robert. "No magic bullet: A critical perspective on disarmament, demobilization and reintegration (DDR) and weapons reduction in post-conflict contexts". The Round Table, vol. 94, no. 379, 2005, pp. 239-252, doi:10.1080/00358530500082684.

Nilsson, Anders. Reintegrating ex-combatants in post-conflict societies. Stockholm, Swedish International Development Cooperation Agency, 2005.

Perera, S. The ethnic conflict in Sri Lanka: A historical and sociopolitical outline. Washington, DC, World Bank, 2001, p. 6.

Richards, Joanne. An institutional history of the Liberation Tigers of Tamil Eelam (LTTE). CCDP Working Paper. The Centre on Conflict, Development and Peacebuilding, 2014, p. 96.

Roberts, Michael. "Turning former LTTE personnel into Sri Lankan citizens?" Groundviews, 28 Oct. 2011, https://groundviews.org/2011/10/28/turning-former-lt te-personnel-into-sri-lankan-citizens/.

Schröter, Melani. Silence and concealment in political discourse. John Benjamins Publishing Company, 2013.

Silva, Kalinga Tudor, M.G.M. Razaak, Dhammika Herath, and Ramila UsoofThowfeek. Postwar livelihood trends in northern and eastern Sri Lanka. Background paper, 5. International Centre for Ethnic Studies and World Bank, 2018, p. 56, http://ices.lk/wp-content/uploads/2018/11/Post-War-Livelihood.pdf.

Subedi, D. B. "Dealing with ex-combatants in a negotiated peace process: Impacts of transitional politics on the disarmament, demobilization and reintegration programme in Nepal”. Journal of Asian and African Studies, vol. 49, no. 6, 2013, pp. 672-689, doi:10.1177/0021909613507537.

Usoof-Thowfeek, Ramila. Psychosocial assessment of the war affected Northern and Eastern Provinces of Sri Lanka: Distress and growth post-war. International Centre for Ethnic Studies, 2018, www.ices.lk.

Waldorf, Lars. "Just peace? Integrating DDR and transitional justice". Transitional justice and peacebuilding on the ground: Victims and ex-combatants, edited by Chandra Lekha Sriram, Jemima Garcia-Godos, Johanna Herman, and Olga Martin-Ortega, Routledge, 2013, pp. 62-80. 
Webber, David, Marina Chernikova, Arie W. Kruglanski, Michele J. Gelfand, Malkanthi Hettiarachchi, Rohan Gunaratna, Marc-Andre Lafreniere, and Jocelyn J. Belanger. "Deradicalizing detained terrorists". Political Psychology, vol. 39, no. 3, 2018, pp. 539-556, doi:10.1111/pops.12428.

Weisdorf, Matti, and Birgitte Refslund Sørensen. "To be or not to be a hero: Recognition and citizenship among disabled veterans of the Sri Lankan army". Conflict and Society, vol. 5, no. 1, 2019, pp. 96-114, doi:10.3167/arcs.2019.050107. 



\section{Part IV}

\section{Forgotten resources}





\title{
11 Constructive resistance and the importance of not knowing in transitional justice
}

\author{
Briony Jones
}

\section{Rethinking transitional justice}

There is a significant and compelling body of work on transitional justice that encourages scholars, practitioners and policymakers to rethink the field's assumptions about how best to address large-scale human rights violations of the past. This might be in relation to its liberal vision of transition and democracy (Sharp 2018), the ability of international experts and transitional justice entrepreneurs to generate the change that they want in varied domestic contexts (McAuliffe 2017), or the expectation that transitional justice should bring about closure and reconciliation (Weinstein 2011). I believe that this work should be taken seriously, and that if we wish to think differently about transitional justice, then we must interrogate and reflect on the labels we give to actors whose motivations, actions and impacts we try to understand. On the one hand, transitional justice comprises the mechanisms, interventions and processes of what has been described as the "global norm" (Nagy 2008). We have United Nations (2010) pillars, transitional justice toolkits ${ }^{1}$ and a burgeoning of non-governmental organizations (NGOs) and consultancies to advise and direct transitional justice (Rubli 2012). On the other hand, transitional justice comprises the always incomplete and subjective impulse to reckon with past violence and to find different ways of living together (Weinstein 2011). We have imaginations of future possibilities, calls to unity and debates over what counts as justice or peace. The empirical reality of societies which are embarking on dealing with the past reflects an iterative movement between these two versions of transitional justice mechanisms and incomplete reckoning - which in fact cannot be easily separated.

As a field, transitional justice scholars are seeking new ways of capturing and comprehending the politics of transitional justice in practice. Much of what shapes this politics is the motivations and actions of actors. In this chapter, my focus is on actors who resist, often designated as "spoilers" in the transitional justice literature, but who offer a valuable analytical window into the ways transitional justice can be reimagined. This it to say that "spoilers" - or actors considered to be motivated primarily by a desire to

DOI: $10.4324 / 9781003167280-15$ 


\section{Briony Jones}

block transitional justice - have not yet been fully understood in the transitional justice field. The tendency to dismiss actors assumed to be working against transitional justice means that the label of spoiler obfuscates ongoing and legitimate debates over the nature of past violence and the different ways to address it. This chapter builds on my prior work on resistance and transitional justice (Jones and Bernath 2017a) and combines it with a politics of knowledge lens in order to further strengthen my argument that "resistance" should be taken seriously as an object of inquiry in transitional justice. There is varied work on resistance from different fields, but I use here the work of political geographers, anthropologists and political scientists to understand resistance as socially constructed, meaning that we should try and understand why and how acts are labelled as resistance when others are not. This is connected to a politics of knowledge lens as the latter focuses on how certain forms of knowledge come to prevail over others. By "politics of knowledge" I mean how the recognition of knowledge as (valid) knowledge is political, and what this tells us about the power relations between actors, the legitimacy of different perspectives, and how what we "know" is shaped by context.

Combining these insights, I draw on a case study of Côte d'Ivoire, where supporters of the former president have been labelled as spoilers of transitional justice. After first situating resistance and transitional justice in the literature on the contested politics of transitional justice, I suggest thinking about resistance as a "way of knowing", or rather "not knowing", in relation to transitional justice. I aim to show how analysing "resistance" as socially constructed can point to the necessarily incomplete nature of "knowing" in transitional justice contexts. Going further, I also argue that not knowing is important, as it creates space for divergent and varied voices in transitional justice.

\section{Transitional justice and its politics of knowledge}

Transitional justice is a field defined by porous boundaries between research and practice, between experientially informed and generalized knowledge, between universals and context. As such it is, in its current state, an assemblage of actors, ideas, actions and objects (Jones and Lühe 2021) generating, claiming and responding to various forms of knowledge. The reason this is important is because transitional justice, in practice, is typically a normative endeavour seeking to generate change. This normative project overlaps with, but can be distinguished from, transitional justice as a journey to reckon with the past. The former seeks "truth" in order to settle accounts and seek order, in response to the violence of the past. This implicitly associates a lack of knowledge, or disagreement over how to know the past, with the danger of not moving forward towards peace and justice. The latter version of transitional justice as a journey to reckon with the past cannot be so sure of its end point, or the road that must be travelled to get there. Joining the critiques of 
other scholars who caution against a desire to seek order and closure in the aftermath of large-scale violations of human rights (Schaap 2007), in this chapter I accept the contested politics of transitional justice and argue that they can be better understood through an empirically informed intellectual enquiry on resistance in terms of those who resist, acts of resistance and the objects of resistance.

By seeking change - be it peace, justice, democratic transition - transitional justice is political. Not all change is equal, and not all voices are heard. The "global norm" of transitional justice has been critiqued for its focus on liberal democracy (Sharp 2018), its association with good governance agendas of liberal peace (Sriram 2017) and its marginalization of the voices of the supposed beneficiaries (Madlingozi 2010) as well as of scholars from the Global South (Kagoro 2012). It is hard for transitional justice to escape its reputation as "Western" and "liberal" when, despite the significant role played by Global South experiences in the formation and shaping of the field (Jones and Lühe forthcoming), the flows of money and "expertise" consolidate "knowledge" as internationally mobile, Western-educated and articulated in the language of the toolkits and pillars associated with the United Nations and international NGOs (McAuliffe 2017, p. 180). What we have, then, is a narrowing of the knowledge landscape of transitional justice and the ways that transitional justice advocates tend to "know" the problem of violence and the solution of transitional justice through trials, truth commissions, reparations or institutional reform. This is not to undermine the work which is done in pursuit of justice or the motivations of those actors. Rather, it is to state that debates about the legitimacy of transitional justice have an important knowledge dimension, asking who can speak on behalf of whom, and how monoliths of knowledge can be broken down, where they remain or emerge.

The monoliths of knowledge which have been a target of critique are varied. Kagoro contends that the origins and development of the transitional justice norm are part of a "post-cold war ascendency of particular, culturally laden narratives about history, society, governmentality and justice" (2012, p. 10). He goes on to write of transitional justice's "knowledge imperialism" (p. 12), a term that reflects the substantial debate in the transitional justice literature about the extent to which the "dominant script" (Sharp 2018, p. ix) of transitional justice continues the imbalances, and even violence, of relations between the Global North and the Global South. Indeed, the production of knowledge on and for transitional justice is not a practice that different actors can engage in equally for "only a particular set of people, in a particular set of circumstances, is able to shape the research agenda which in turn informs policies that shape the world" (Nouwen 2014, p. 258).

This leads to a second area of concern and debate, that of the distinction between the "foreign expert" and the "local beneficiary". Local ownership as a lens of critique emerged largely in response to the standardized solutions offered by international actors from the Global North to the Global South, 
which have been critiqued for undermining local ownership in terms of control, process and substance (Sharp 2013). The "local turn" in transitional justice includes work on "justice from below" (McEvoy and McGregor 2008), positionalities and standpoints (Shaw, Waldorf and Hazan 2010), and African transitional justice (Bennett et al. 2012), among others. However, as noted above, the assumption persists of an unequal binary between international "experts" and local "knowledge" although the latter has instrumental value to the experts in relation to policy advocacy. Therefore, any attempt to reclaim, revive or render visible the "local" in transitional justice may still be read as an act of those with epistemic privilege seeking to give back power to those whose voices have been marginalized. Thus, instead of deconstructing which voices are seen to be expert and which are seen to be local in the first place, these critiques invariably assume and perpetuate a problematic "sense of naturalness and inevitability" of transitional justice (Sharp 2018, p. 1) and the positions assigned to its different actors. This has profound effects on the way we think about, and do, transitional justice. These effects are of course complex and not necessarily negative. The important aspect to highlight for the purpose of this chapter is that their very existence narrows the range of permissive ways of understanding past violence and the justice needed to repair it.

One influential debate about expanding the ways of knowing which underpin transitional justice is that of the legal versus non-legal approaches. Earlier work had already called for transitional justice to look beyond the legal (McEvoy 2007) and to consider not only other disciplinary insights from anthropology, psychology and criminology, for example, but also nonlegal mechanisms such as truth commissions, symbolic reparations and traditional forms of healing (Thomson and Nagy 2011). The legalism of transitional justice is perhaps not surprising, as the challenge with early cases of transitional justice, such as in Argentina, was to identify the appropriate legal tool with which to address past human rights violations (Murphy 2017, p. 29). But this has come to be seen as a "hegemonic quality of law" (Campbell and Turner 2008, p. 378) and empirical research has highlighted the ways in which legal practice in tribunals narrows the set of permissible narratives and seeks to solidify the expertise of the law and lawyers (Wilson 2016; Kelsall 2006). The dominant paradigm of transitional justice, crystallized in the global norm, is still seen to focus heavily on civil and political rights and legal remedies to the exclusion of other violations and remedies (Miller 2008; Palmer et al. 2015; Evans 2016).

These monoliths of knowledge need to be broken down because they do not represent the necessarily contested spaces in which transitional justice interventions take place. If the contestation cannot be seen, for example because of a selective approach to violence and/or a desire to seek closure of the past, then this will weigh on the relationship between transitional justice advocates and those who have experienced violence. There is a significant body of work which highlights the necessarily incomplete nature of 
reconciliation in transitional justice contexts. Schaap (2007) warns of the irreconcilability of social conflict and Little (2009) suggests that a contested politics is perhaps more "normal" following past violence. In contrast, transitional justice literature tends to approach resistance as a problem of "spoilerism" or "deviancy" of those unwilling to accept its processes (Jones and Bernath 2017b, p. 3). Understanding the role of resistance as more than spoilerism builds on work which holds that contestation is present and important, and that resistance may point towards other ways of understanding the past violence and how to respond to it. I argue here that resistance reminds us of what we don't know and that recognizing the incompleteness of our knowledge is important for moving towards answering the crisis of legitimacy in transitional justice.

\section{Resistance as a way of not knowing transitional justice}

In previous work on resistance and transitional justice I have found, along with my co-authors and collaborators, that we can make gains in our analysis of transitional justice if we take resistance seriously as an object of enquiry (Jones and Bernath 2017a). This is an important argument to make because resistance, in transitional justice scholarship, is primarily associated with spoilers. This identity of the spoiler is rather one-dimensional, typically based on the assumption that such actors are only interested in self-preservation through disruption of a formal transitional justice process: by "old regime loyalists" (Subotić 2014, p. 135), by a national political leadership against international criminal procedures (Hansen 2014, p. 119) or by "bad" victims who refuse to accept outcomes of transitional justice processes (Hamber and Wilson 2002, p. 45). This has three key effects. First, it assumes that self-preservation is necessary because those actors have something to fear from the process, implying that they must have been involved in past violence and are the potential targets of any criminal or justice-related intervention. This sets up a moral hierarchy between the values of those who resist transitional justice and those who promote it. Second, it casts resistance as a technical problem of process, something to be overcome if transitional justice actors are to succeed in their ambitions. This limits our understanding of what are highly political and contested contexts. Third, it assumes that what are observed to be acts of resistance can be meaningfully understood in sole reference to transitional justice, i.e. that they are motived, above anything else, by responding to a transitional justice intervention and its specific goals.

The implication of these assumptions is that they go on to make transitional justice itself the centre of our analyses. Learning from the "inside-out" work of scholars on transitional justice such as McAuliffe (2017, p. 22), it is more illuminating, however, to start with understanding in their own right the motivations, actors and effects of resistance which may only partly be related to the specific transitional justice intervention being undertaken 
(Jones and Bernath 2017b). For if we begin the other way around - with the transitional justice intervention first and ask who resists it - we may miss valuable insights into other contestations and debates which might overlap with, but can also pre-date or be only tangentially connected to, transitional justice. We might think here, for example, of colonial histories of violence or of the historical marginalization of groups who are either elevated or targeted by a particular transitional justice intervention. To assume that all acts of resistance can be addressed by either neutralizing spoilers or tweaking the transitional justice intervention is short-sighted and continues the problematic "sense of naturalness and inevitability" of transitional justice (Sharp 2018, p. 14). Moreover, "since transitional justice is inherently political and contested, resistance is necessarily present in multiple forms in the empirical unfolding of transitional justice" (Jones and Bernath 2017a, p. 5). We should therefore not see it as abnormal but as something which we expect to find and that can be used to help us to understand different perspectives on violence, peace, truth and justice. Resistance to transitional justice not only questions its processes but shapes them (Salehi 2018) and holds the key to make sense of the empirical unfolding of transitional justice. In doing so we need to see it as more than the desperation of spoilers and more than a problem requiring a technical fix. We should see resistance instead as a way to bring to the surface what we do not yet understand, or know, about transitional justice and its politics.

It is hence useful to think more constructively about the role of resistance in transitional justice. We can think of the attempt to understand resistance as a new lens, a way of knowing how transitional justice plays out in specific contexts and how it is perceived and experienced by the supposed beneficiaries. Resistance reminds us that we do not in fact know violence or justice in their entirety. It reminds us to be humble and to seek as inclusive a dialogue as possible before we can even begin to make claims to know what has happened in the past and how it should be addressed. In the following section, a short example from Côte d'Ivoire will be used to illustrate how this more constructive approach to resistance and "not knowing" can be analytically useful. These reflections will build on previous work I have published on the subject (Jones 2017) and are based on qualitative empirical work undertaken in 2014, as well as ongoing desk-based research on transitional justice in Côte d'Ivoire. The data was generated through semi-structured interviews, observations, and focus groups both in Côte d'Ivoire and with diaspora in the United States and the United Kingdom. ${ }^{2}$

\section{Côte d'Ivoire: knowledge claims and justice politics}

The combat for the liberation of Laurent Gbagbo is a combat for the return of democracy.

$(\text { Interview } 131014 \mathrm{~F})^{3}$ 
Following independence from France in 1960, Côte d'Ivoire was led by Felix Houphouët-Boigny and his Parti Démocratique de la Côte d'Ivoire - Rassemblement Démocratique Africain (Democratic Party of Côte d'Ivoire), which remained the only political party until 1990 . This was seen by many commentators as a time of stability, management of ethnic tensions, and economic prosperity (Diallo 2005). Following the introduction of multi-party politics and Houphouët-Boigny's death in 1993, there was a series of political crises connected to ethnic divisions, regional splits and claims to autochthony (Bah 2010). A civil war in 2002 was followed by the creation of a unity government in 2003, a buffer zone between the north and south of the country, further violence and then finally the signing, in 2007, of the Ouagadougou Agreement. The 2010 presidential elections (postponed from 2005) were supposed to solidify unity within the country and mark a formal end to the peace process. However, contested results in the second round of the presidential run-off elections led to both the incumbent Laurent Gbagbo and his opponent Alassane Ouattara declaring victory. The African Union, the Economic Community of West African States and the United Nations (UN) supported the election of Ouattara amid high levels of post-election violence from 2010-11. The crisis finally ended on 11 April 2011, after the capture and house arrest of Gbagbo.

Interwoven with these events were acts of political violence from 19902011, which produced a variety of victims whose cases were supported by different political parties. Moreover, the decision of the UN Security Council to announce the election result in favour of Ouattara, in direct opposition to the result announced by the Ivorian Constitutional Council which declared Gbagbo the winner, set the stage for ongoing disagreement, resentment and lack of transparency over the election and its result (Bellamy and Williams 2011, p. 832). The significant role of the former colonial power of France and its troops in using force to protect civilians and in the arrest of Gbagbo also "blurred the lines between human protection and regime change ... and [raised questions] about the place of neutrality and impartiality in UN peacekeeping" (p. 835). These controversies have not been helped by a continued narrative of a "victor's justice" for Ouattara and his supporters. Among other international actors, the independent commission established by the UN Human Rights Council has expressed concern that investigations by the national military and public prosecutors have been limited to former officials and allies of Gbagbo (Baldo 2011; ICG 2011). McGovern (2011), in his detailed anthropological work on the period preceding the post-election crisis "insists on a multicausal explanation of the Ivorian conflict" (p. 25). In doing so, he refuses to accept the tendency of both Ivorian and non-Ivorian analyses to seek "neat" (p. 7) categories of ethnic, religious, and political affiliation which can explain a "victor" and a "loser". However, the dominant discussion among actors both inside and outside of the country is about the nature of the transitional justice process and whether it is biased in favour of Ouattara and his supporters. 
Despite these complexities and contestations, or perhaps because of them, the subsequent transitional justice process was put in place quickly by the new President Ouattara. The Special Inquiry and Investigation Unit on the post-electoral crisis was set up, the Rome Statute was ratified, the International Criminal Court (ICC) began its proceedings and the national courts were activated. ICC indictments for crimes against humanity were issued against Laurent Gbagbo and Charles Blé Goudé. Their cases were joined and then they were both acquitted in February 2020, with the acquittal upheld on March 31, 2021. An ICC indictment was also issued against Gbagbo's ex-wife Simone Gbagbo, who was convicted in the Ivorian national courts to 20 years' imprisonment but who was then released under a 2018 amnesty. Several non-judicial transitional justice institutions were also established, including the Commission dialogue, vérité et reconciliation (CDVR - Truth and Dialogue Commission), the Ministry of Solidarity, Family, Women and Children and its war victims' department, and the National Program for Social Cohesion. Institutional reforms to protect the right to guarantees of non-recurrence and Security Sector Reform were launched and the National Security Council reinstated. Their design and operation met UN standards, but their functioning has been strongly influenced by the political strategies and power games in Côte d'Ivoire (Adou Djané and Jones forthcoming). For example, the final report of the CDVR remained hidden from public scrutiny from 2014 until 2016, and President of the CDVR Konan Banny is a controversial figure, seen by many to be leveraging his position to gain political weight when he became involved in the 2015 presidential election contest.

These contestations pivot on historical injustices and grievances as well as the specifics of the way in which the conflict ended and transitional justice has been implemented. There are varied resistances that we can observe in response: to the different mechanisms of the transitional justice process; to Ouattara's presidency; to the ICC indictments and now appeal against the acquittal of Gbagbo and Blé Goudé. This resistance, following the 2011 violence, has been located in certain actors and interpreted in particular ways. From the beginning of the transitional justice process, pockets of militia violence have been interpreted by the government and its supporters as attempts, by disgruntled "losers" of the transition, to destabilize the country and disrupt the justice process. However, according to Adou Djané (2017, p. 21), this violence is designed to target the political transition itself, meaning the state and current government. The latter, of course, forms the basis of a transitional justice process, but it is not the same, and this distinction is important.

There are also supporters of the former President, Gbagbo, and members of his political party, the Front Populaire Ivoirien (Ivorian Popular Front), who are seen as unable to accept Ouattara's victory. These actors have boycotted the work of the CDVR and political dialogues (Adou Djané 2017, p. 25). In addition, supporters of Gbagbo in the diaspora have organized 
themselves into organized resistance, publishing leaflets denouncing the current president and demanding transparency of the election results of 2010 (Jones 2017).

These actors - supporters of the former president - are the classic "spoilers" of transitional justice: disgruntled; unable to accept democratic process; afraid of being held accountable for crimes; and unwilling to embrace its "values". Cast as the "losers" of the violence as well as of the transition, it is assumed by domestic and international actors that this is the end of the story. Former regime loyalists are known to want to block political progress, to delegitimize Ouattara's presidency and to avoid justice (Jones 2017). The forms of resistance I have described above - protests, violence, boycotts and public denouncements - are also simply understood to be acts of incivility associated with a "past" of disorder and violence (Jones and Adou Djané 2018). The underpinning narratives about resistance to transitional justice in Côte d'Ivoire are thus (a) that it is motivated by failure to accept the "right" outcome of the elections and of the justice process, and (b) that it is part of a deviant disorder of past violence that has no place in the present justiceseeking process, or in the imagined future of peace and democracy.

However, analysis of the resistance can tell us so much more. It is important to see it above all through the lens of "the continuity of violence that characterises the political system" (Adou Djané 2017, p. 17) and thus to understand it as "continual doubting of the political and social contract to which the current transitional justice process has been appended" (p. 17). The complex history of socio-political crises related to citizenship, autochthony and economic collapse in Côte d'Ivoire (Akindès 2004) finds a focal point in and through transitional justice, so while labelling acts of resistance by the election "losers" is an easy interpretation of events, it also reproduces the (partial) narrative of those who are resisted. In my research I have found that those who resist do, in fact, connect their actions to bigger questions of historical standing: "all those in love with justice and democracy must resist" (Zokou 2012), or "Alassane Dramane Ouattara was forced on Côte d'Ivoire by the French army" (Interview 260314F). Interestingly, their counter-narrative echoes similar concerns raised by more "moderate" voices over the transparency of the UN when declaring Ouattara the winner, the lack of transparency of the work of the CDVR, or the bias in prosecutions against supporters of Gbagbo (Jones 2017, p. 47), which makes it even more problematic to simply discount it as not based on facts.

The supposed acts of resistance against transitional justice in fact tell us that the transitional justice process has not been, and perhaps cannot be, able to fully reveal the violence and the contexts which led to it. The focus on specific acts of violence following the 2010 election precludes a larger discussion about the involvement of the former colonial power France, about the historical exclusion of certain ethnic groups from political power and about the distribution of wealth and land in the country. Now that many of the mechanisms have finished their work, including the CDVR, the 
contestations continue. The decision by the ICC to lift the travel restrictions on Gbagbo and Blé Goudé led to the observation that "[o]nce again, the International Criminal Court is upending Ivorian politics" (Africa Confidential 2020). This decision put pressure on the presidential election of October 2020, which was won by Ouattara amid controversy over his "third term", boycotts from the opposition, and violence. ${ }^{4}$ The limits of Ouattara's reconciliation, based on economic recovery and stability through decisive action from the centre of presidential power (N'Da and Fokou 2021), will be tested, as will the limits of a hastily completed and certainly limited transitional justice process.

\section{Concluding remarks}

There is a central contradiction in dominant transitional justice discourse and practice. There is a desire to seek the truth and to claim it when found, while at the same time specific transitional justice mechanisms and processes are necessarily incomplete. This may be due to a selective mandate which looks at violent acts committed between a certain range of dates or by particular actors. It may be due to its instrumentalization by varied actors with particular agendas. It may also be because of the impulse to agree on one narrative, which can unify and form the basis of a future of peace. Such selective politics of knowledge can be enriching and valuable if we can find ways of reading them and understanding what they communicate. In this chapter I have tried to show how resistance can highlight the usefulness of not knowing, of demonstrating the incompleteness of attempts, through transitional justice, to order and categorize the past and to shed a light on diverse experiences and diverse perspectives on the ways forward.

At the beginning of this chapter, I outlined some well-known critiques of transitional justice. I agree with Colvin's (2008, p. 424) assessment that the field does not need yet more knowledge; instead, it needs to rethink its failed relationship to the "other'. In the case of Côte d'Ivoire, more assessments of transitional justice mechanisms and their impacts, while important, do not necessarily help to overcome the frames of reference set by transitional justice discourse and practice. If we stay within the "naturalness and inevitability" of transitional justice (Sharp 201, p. 1), claims to knowledge about the past are less easy to critique. Transitional justice processes and experts all too often make claims to know what happened, how it should be addressed and what kind of future should result. Frequently, there is limited space to recognize what is not known, or what maybe cannot ever be known. Resistance, if nothing else, reminds us that all knowledge of the past is incomplete. I argue that in order to create a more ethical relationship with "the other" with alleged "spoilers", "bad losers" or "unthankful beneficiaries" - humility is fundamental. It allows transitional justice "experts" to begin their work with acknowledging what is not known and what can be learnt from listening to others. Such a process is not easy, as the discussions about inclusivity by 
Vollhardt et al. in Chapter 12 of this volume demonstrate. Learning from resistance is but one way of opening dialogue. It can be difficult because of the perceived "incivility" of those who resist (Jones and Adou Djané 2018), or because of an expected clash of values. But dialogue does not have to be easy to ensure that we are attentive to ongoing efforts to learn from the past rather than seeking to close it down.

\section{Notes}

1 www.ohchr.org/EN/Issues/RuleOfLaw/Pages/TransitionalJustice.aspx.

2 The fieldwork was conducted in 2014 in collaboration with Dit Fatogoma Adou Djané based at the Centre Suisses de Recherches Scientifiques in Abidjan, but I take sole responsibility for the reflections presented in this chapter.

3 The fieldwork was generously funded by the Swiss National Science Foundation as part of the project 'Resisting Transitional Justice? Alternative Visions of Peace and Justice' which ran from 2012-2015.

4 www.hrw.org/news/2020/12/02/cote-divoire-post-election-violence-repression.

\section{References}

Adou Djané, Dit Fatogoma. "Resistance to transitional justice in the context of political violence in Côte d'Ivoire". Resistance and transitional justice, edited by Briony Jones and Julie Bernath, Routledge, 2017, pp. 17-34.

Adou Djané, Dit Fatogoma, and Briony Jones. "Commission of Dialogue, Truth and Reconciliation," Encyclopedia of Transitional Justice: Second Edition, edited by Lavinia Stan and Nadia Nedelsky, Cambridge University Press, forthcoming.

Adou Djané, Dit Fatogoma, and Briony Jones. "Country study: Côte d'Ivoire". Encyclopaedia of transitional justice, edited by Lavinia Stan, Cambridge University Press, forthcoming.

Africa Confidential. Affairs of the state and of the heart. 1 June 2020, www.africa-con fidential.com/article-preview/id/12983/Affairs_of_state_and_of_the_heart. Accessed 1 July 2020.

Akindès, Francis. The roots of the military-political crises in Côte d'Ivoire. Research report No. 128, 2004, Uppsala, Nordiska Afrikainstitutet.

Bah, Abu Bakkar. "Democracy and civil war: Citizenship and peacemaking in Côte d'Ivoire". African Affairs, vol. 109, no. 437, 2010, pp. 597-615.

Baldo, Suliman. "Ivory Coast must avoid victor's justice: Podcast with Suliman Baldo". In Focus, no. 3, 2011, http://ictj.org/content/ictj-focus-issue-3.

Bellamy, Alex J., and Paul D. Williams. "The new politics of protection? Côte d'Ivoire, Libya and the responsibility to protect". International Affairs, vol. 87, no. 4, 2011, pp. 825-850.

Bennett, Tom, Eva Brems, Giselle Corradi, Lia Nijzink, and Martien Schotsmans. African perspectives on tradition and justice. Intersentia, 2012.

Campbell, Colm, and Catherine Turner. "Utopia and the doubters: Truth, transition and the law". Legal Studies, vol. 28, no. 3, 2008, pp. 374-395.

Colvin, Christopher J. "Purity and planning: Shared logics of transitional justice and development". The International Journal of Transitional Justice, vol. 2, no. 3, 2008, pp. $412-425$. 


\section{Briony Jones}

Diallo, Youssouf. From Stability to uncertainty: A recent political history of Côte d'Ivoire. Max Planck Institute for Social Anthropology working paper no. 74, 2005, Max Planck Institute.

Evans, Matthew. "Structural violence, socioeconomic rights, and transformative justice". Journal of Human Rights, vol. 15, no. 1, 2016, pp. 1-20.

Hamber, Brandon, and Richard Wilson. "Symbolic closure through memory, reparation and revenge in post-conflict societies". Journal of Human Rights, vol. 1, no. 1,2002 , pp. $35-53$.

Hansen, Thomas Obel. "The vertical and horizontal expansion of transitional justice: Explanations and implications for a contested field". (eds.) Transitional Justice Theories, edited by Susanne Buckley-Zistel, Teresa Koloma Beck, Christian Braun, and Friederike Mieth, Routledge, 2014, pp. 105-124.

International Crisis Group (ICG). A critical period for ensuring stability in Côte d'Ivoire. Africa report no. 176, ICG, 2011.

Jones, Briony. "Seeking a 'just justice': Discursive strategies of resistance to transitional justice in Côte d'Ivoire". Resistance and transitional justice, edited by Briony Jones and Julie Bernath, Routledge, 2017, pp. 35-50.

Jones, Briony, and Julie Bernath. "Introduction: Resistance and transitional justice". Resistance and transitional justice, edited by Briony Jones and Julie Bernath, Routledge, 2017b, pp. 1-16.

Jones, Briony, and Julie Bernath, editors. Resistance and transitional justice. Routledge, 2017a.

Jones, Briony, and Adou Dit Fatogoma Djané. "Reading the 'uncivil' in civil society resistance to transitional justice in Côte d'Ivoire". Political Geography, vol. 67, 2018, pp. 135-144.

Jones, Briony, and Ulrike Lühe. "Knowledge for peace: Transitional justice and the politics of knowledge in theory and practice." Knowledge for peace: Transitional justice and the politics of knowledge in theory and practice, edited by Briony Jones and Ulrike Lühe, Edward Elgar, 2021, pp. 1-19.

Jones, Briony, and Ulrike Lühe. "The politics of knowledge and an African transitional justice: Analysing Africa as a constitutive outside". Routledge handbook on African peacebuilding, edited by Bruno Charbonneau and Niagalé Bagayoko, Routledge, forthcoming.

Kagoro, Brian. "The paradox of alien knowledge, narrative and praxis: Transitional justice and the politics of agenda setting in Africa". Where law meets reality: Forging African transitional justice, edited by Moses Crispus Okello, Chris Dolan, Undine Whande, Nokukhanya Mncwabe, and Stephen Oola, Pambazuka Press, 2012, pp. 4-52.

Kelsall, Tim. "Politics, anti-politics, international justice: Language and power in the Special Court for Sierra Leone". Review of International Studies, vol. 32, no. 4, 2006, pp. 587-602.

Little, Adrian. "The Northern Ireland paradox". The politics of radical democracy, edited by Adrian Little and Moya Lloyd, Edinburgh University Press, 2009.

Madlingozi, Tshepo. "On transitional justice entrepreneurs and the production of victims". The International Journal of Transitional Justice, vol. 2, no. 2, 2010, pp. 208-228.

McAuliffe, Padraig. Transformative transitional justice and the malleability of postconflict states. Edward Elgar, 2017.

McEvoy, Kieran. "Beyond legalism: Towards a thicker understanding of transitional justice”. Journal of Law and Society, vol. 34, no. 4, 2007, pp. 411-440. 
McEvoy, Kieran, and Lorna McGregor. Transitional justice from below: Grassroots activism and the struggle for change. Hart Publishing, 2008.

McGovern, Mike. Making war in Côte d'Ivoire. Hurst and Co., 2011.

Miller, Zinaida. "Effects of invisibility: In search of the 'economic' in transitional justice”. The International Journal of Transitional Justice, vol. 2, no. 3, 2008, pp. 266-291.

Murphy, Colleen. The conceptual foundations of transitional justice. Cambridge University Press, 2017.

Nagy, Rosemary. "Transitional justice as global project: Critical reflections". Third World Quarterly, vol. 29, no. 2, 2008, pp. 275-289.

N'Da, Serge Alain, and Gilbert Fokou. "Knowledge asymmetry and transitional justice in Côte d'Ivoire". Knowledge for Peace: Transitional justice and the politics of knowledge in theory and practice, edited by Briony Jones and Ulrike Lühe, Edward Elgar, 2021, pp. 75-98.

Nouwen, Sarah M. H. “'As you set out for Ithaka'. Practical, epistemological, ethical, and existential questions about socio-legal empirical research in conflict". Leiden Journal of International Law, vol. 27, no. 1, 2014, pp. 227-260.

Office of the High Commissioner for Human Rights. Special Rapporteur on the promotion of truth, justice, reparation and guarantees of non-recurrence. 2020. www. ohchr.org/EN/Issues/TruthJusticeReparation/Pages/Index.aspx. Accessed 14 April 2020.

Palmer, Nicola, Briony Jones, and Julia Viebach. "Introduction: Ways of knowing atrocity: A methodological enquiry into the formulation, implementation, and assessment of transitional justice". Canadian Journal of Law and Society, vol. 30, no. 2, 2015, pp. 173-182.

Rubli, Sandra. Transitional justice: Justice by bureaucratic means?swisspeace working paper, 2012, www.files.ethz.ch/isn/154626/WP4_2012.pdf. Accessed 14 April 2020.

Salehi, Mariam. "Political resistance: How cross-cutting frictions drive and define transitional justice in Tunisia". Justice Info, 17 July 2018, www.justiceinfo.net/en/justi ceinfo-comment-and-debate/opinion/38036-political-resistance-how-cross-cutting-fricti ons-drive-and-define-transitional-justice-in-tunisia.htm. Accessed 7 December 2018.

Schaap, Andrew. "The time of reconciliation and the space of politics". Law and the politics of reconciliation, edited by S. Veitch, Ashgate, 2007.

Sharp, Dustin N. "Interrogating the peripheries: The preoccupations of fourth generation transitional justice". Harvard Human Rights Journal, vol. 26, 2013, pp. 149-178.

Sharp, Dustin N. Rethinking transitional justice for the twenty-first century: Beyond the end of history. Cambridge University Press, 2018.

Shaw, Rosalind, Lars Waldorf, and Pierre Hazan. Localizing transitional justice: Interventions and priorities after mass violence. University of Stanford Press, 2010.

Sriram, Chandra L. "Beyond transitional justice: Peace, governance, and rule of law". International Studies Review, vol. 19, no. 1, 2017, pp. 53-69.

Subotić, Jelena. "Bargaining justice: A theory of transitional justice compliance". Transitional justice theories, edited by Susanne Buckley-Zistel, Teresa Koloma Beck, Christian Braun, and Friederike Mieth, Routledge, 2014, pp. 128-143.

Thomson, Susan, and Rosemary Nagy. "Law, power and justice: What legalism fails to address in the functioning of Rwanda's gacaca courts". The International Journal of Transitional Justice, vol. 5, no. 1, 2011, pp. 11-30. 


\section{Briony Jones}

United Nations. Guidance note of the Secretary General: United Nations approach to transitional justice, March 2010, www.un.org/ruleoflaw/files/TJ_Guidance_Note_ March_2010FINAL.pdf. Accessed 30 June 2020.

United Nations. Set of principles for the protection and promotion of human rights through action to combat impunity (E/CN.4/Sub.2/1997/20/Rev.1), 1997, https:// digitallibrary.un.org/record/245520?ln=en. Accessed 14 April 2020.

Weinstein, Harvey M. "Editorial note: The myth of closure, the illusion of reconciliation: Final thoughts on five years as co-editor-in-chief". The International Journal of Transitional Justice, vol. 5, no. 1, 2011, pp. 1-10.

Wilson, Richard A. "Expert evidence on trial: Social researchers in the international criminal courtroom”. American Ethnologist, vol. 43, no. 4, 2016, pp. 730-744.

Zokou, S. Communiqué du presse du Comité de Pilotage des Actions de la Diaspora. 20 September 2012, www.civox.net/Communique-de-presse-du-Comite-de-Pilotage-de s-Actions-de-la-Diaspora-CPAD_a1404.html. Accessed 30 March 2017. 


\title{
12 Inclusive narratives of suffering
}

\author{
Johanna Ray Vollhardt, Michelle Sinayobye Twali \\ and Sumedha Jayakody
}

One important step towards rebuilding social relationships between former adversary groups in the aftermath of collective violence may entail overcoming the mindset that loss and suffering was confined to one's own exclusively defined community. A decade of research (for reviews see Noor et al. 2017; Vollhardt 2009, 2015) has shown how inclusive victim consciousness the view that the losses and struggles endured by one's group are similar to those endured by other groups - is linked to support for reconciliation, reparation and prevention of further injustice. Such findings open new perspectives on transitional justice as an inclusive process during which people may discover commonalities in grievances, beyond the boundaries of communities they are conventionally associated with. For example, every year since 2005, many Israeli Jews and Palestinians hold an Alternative Memorial Day event to recognize and support families on both sides who have lost loved ones during the intractable conflict (Corry and Khatib 2019; Shnabel et al. 2017). However, there are also risks associated with overly inclusive narratives that fail to acknowledge power differences and resultant inequalities in experiences between groups - just as calls for reconciliation and harmony may serve to maintain, rather than to challenge, existing inequalities and power relations and therefore may be more problematic than they appear at the surface level (Dixon et al. 2012; Saguy et al. 2009; see also Chapter 11 in this volume). Accordingly, the meaning and consequences of (seemingly) inclusive victim consciousness can differ depending on the power relations of the groups involved. This chapter addresses both the promises and the pitfalls of inclusive narratives of suffering in transitional justice processes, and emphasizes that inclusive victim beliefs, just like any construal of conflict or of victimization, are used rhetorically to serve specific political or social purposes (McNeill and Vollhardt 2020).

\section{What are inclusive narratives of suffering?}

Inclusive narratives of suffering communicate inclusive victim consciousness, which is defined as the recognition of similarities between the suffering of the ingroup and other groups (Vollhardt 2012). This can involve groups in other

DOI: $10.4324 / 9781003167280-16$ 
parts of the world that have suffered in different conflicts due to different oppressors, i.e. global inclusive victim consciousness, such as the perceived similarities between Palestinians and African Americans, or between Jews and Tutsi. It can also involve perceiving similarities between two groups that are in conflict with each other, i.e. conflict-specific inclusive victim consciousness, such as when Catholics and Protestants in Northern Ireland see their suffering as similar (Vollhardt 2015). Conflict-specific inclusive victim consciousness is psychologically more challenging (see also Warner et al. 2014). In some cases - especially those characterized by strong power differences, which we discuss in more detail later in the chapter - inclusive victim consciousness may entail mere acknowledgement that the other group has also suffered, rather than explicit statements on perceived similarities. Acknowledgement of the other side's suffering and their inclusion in who counts as a "victim" is rare and is often contested in conflict narratives (Hameiri and Nadler 2017; Noor et al. 2012). Therefore, acknowledging the other group's victimization without explicitly stating similarities is also an important form of inclusive victim consciousness. It may also often be factually more accurate than claiming similarities in experiences between groups with different histories of oppression or different degrees of power, thereby inviting less reactance and backlash.

\section{What inclusive victim consciousness is not}

Inclusive victim consciousness should not be confused with the assertion that experiences of suffering are the "same" (Nair and Vollhardt 2020). Although this is one way in which people may express a sense of shared grief and loss with other groups, claiming that two groups suffered in the same way or to the same degree often disregards power relations and different histories of oppression (Vollhardt and Twali 2016). Therefore, such statements are often strongly rejected by members of victimized groups who assert that no two experiences are ever the same (Vollhardt et al. 2021). In fact, a study of Jewish Americans reflecting on the Holocaust found that communicating both similarities and differences between the victimized ingroup and other victim groups worldwide resulted in more prosocial outcomes towards other victim groups compared to overly inclusive construals of the ingroup's suffering as a "crime against humanity" that did not acknowledge distinct groups and their respective fates (Vollhardt 2013).

Inclusive victim narratives are also not merely general perceptions of similarity regarding two groups' cultures or another superordinate identity (Garagozov 2016). For example, in a study of Jewish Israelis, perceived shared regional identity as "Middle Easterners" did not increase willingness for reconciliation with Palestinians, while a shared victim identity did (Shnabel et al. 2013). We discuss these effects of inclusive victim narratives on intergroup relations and policy support in more detail below. Here, we simply wish to emphasize that, although the effects of inclusive victim 
consciousness can be understood theoretically as prosocial effects of shared, superordinate identities on intergroup outcomes (Dovidio et al. 2009), the inclusion of other groups in a shared category of "victims of violence and oppression" may be particularly powerful in the context of ongoing violent conflicts and in post-violence transitional justice settings, in comparison to other superordinate identities and social categories that practitioners may use in interventions aimed at fostering peace and social change. In other words, it is not just the boundaries of the group identity that matter but also the content of this shared identity (see also Reicher et al. 2006; Twali 2019).

\section{Challenges in defining the reference points for inclusive victim narratives}

It is crucial to critically examine the reference points and identities that create the basis for inclusive victim narratives. Most research examining this topic focus on singular identities such as ethnicity, nationality, religion or race, which are also often the fault lines of conflict and group-based violence (Nair and Vollhardt 2019; Twali 2019). However, social identities as well as social roles within identity groups are complex and fluid.

First, people have multiple intersecting identities, such as ethnicity, gender and social class, that together inform peoples' experiences of victimization and oppression (Cole 2009; Rosenthal 2016). Some group members may be acutely aware of the impact of these intersecting identities and, based on this "intersectional consciousness" (Greenwood 2008), compare experiences of suffering within the broader social group instead of focusing on comparisons with other ethnic or religious groups' suffering. For example, in a qualitative study among Muslims and Dalits in India, participants discussed the experiences of female versus male Muslims, or Dalits who lived in slums versus those who had obtained middle class status (Nair and Vollhardt 2019). This intersectional consciousness also shaped inclusive victim consciousness (and other comparative victim beliefs such as perceiving that others suffered more, or less than the ingroup) between group members with different intersecting identities (ibid).

Second, group members take on different roles during conflicts, and participate to varying degrees in violent resistance movements and perpetration of violence against the adversary. For example, in a qualitative study on perceptions of collective victimhood among Protestants and Catholics in Northern Ireland (Ferguson et al. 2010), some participants stressed that there were members of their group who had been involved in paramilitary groups and committed violence, in addition to generally belonging to a victimized group. This led some to perceive of "hierarchies of victims" within their group as opposed to just between groups, which is commonly referred to as competitive victimhood (Noor et al. 2012). Moreover, they insisted that only those who did not commit violence were "true" and "innocent" victims (Ferguson et al. 2010). Conversely, other participants in this study emphasized the commonality of suffering among all members of their group, 
without making such distinctions. Thus, both intersecting identities and different roles in conflict can result in the same dynamics within groups that occur between groups, and people may recount inclusive victim narratives revolving around different reference points.

Third, some conflicts redefine the boundaries and identities of the groups involved, thereby creating a new basis for comparisons of suffering (Elcheroth and Reicher 2017; Twali 2019). These transformations occur when alliances between some groups facilitate new superordinate identities, or when internal conflicts and competition for resources create factions among preexisting groups. New social identities transformed through conflicts in this way may thereafter supplant the social identities that existed before the conflict. They may also be more salient and relevant when people construct inclusive narratives of the suffering they experienced during the conflict. For example, interviews with South Sudanese diaspora members about the civil wars in Sudan revealed that the transformation of various groups into larger superordinate identities cut across ethnicities and religion based on these groups' shared experiences of suffering (Twali 2019). Consequently, inclusive narratives of suffering accommodated the experiences of previous outgroups who were now part of a post-conflict superordinate ingroup (for example, Dinkas and Nuers within a transformed South Sudanese superordinate identity) that rarely included other outgroups who did not share their conflict experiences (e.g. Sudanese Arabs).

Fourth, conflicts often make the group identities involved in conflict particularly salient even when they were previously considered insignificant within a country's social, economic and political discourse. This creates challenges in the construction of inclusive victim narratives. Sri Lanka during colonial and post-colonial times provides a good example of this phenomenon. The "divide and rule" policies of the British colonizers (often characterized through territorial segregation and division of populations along linguistic, religious and ethnic fault lines; see Christopher 1988) entailed that minority Tamils were favoured over the Sinhalese majority. For instance, despite being a minority of only $11 \%$ of the population in 1946 (while Sinhalese made up $70 \%$ of the population), the Tamils were represented in the prestigious Ceylon civil service and university admissions at $33 \%$ and 31\%, respectively (de Silva 1984; Schwarz 1983; DeVotta 2002). In the wake of Sri Lanka's independence, Sinhalese-dominated governments eliminated previous disparities but did so by engaging in clientelist policies and diversionary war politics that created new disparities. The Sinhala Only Act of 1956, for instance, which instituted Sinhalese (spoken by the majority) as the official language and discouraged Tamils from entering state employment except in the north and east where Tamil was accepted as the administrative language, or the 1971 policy on education standardization which replaced a merit-based system of university admission with one based on district quotas that curtailed the number of Tamil students receiving free university education provide examples of such practice. These policies transformed Sinhalese 
and Tamil ethnic identities into frozen, exclusive ones with conflict-exacerbating boundaries that fed the three-decade-long civil war (see Abeyratne 2004; DeVotta 2002, 2005). Due to such identity transformations - and considering the different conflict experiences that each group was exposed to, their varied roles in the conflict and levels of power - perceiving similarities in suffering across ethnic group boundaries became psychologically challenging.

Inclusive narratives of suffering used in the transitional justice process should pay attention, therefore, to the scope of comparison - that is, whose suffering is included in these post-conflict narratives. For example, are inclusive narratives of suffering only those that feature former outgroups who are now part of the newly created ingroup based on their experiences of victimization during the conflict (Twali 2019)? What about the narratives that (only) mention those outgroups that suffered at the hands of the same perpetrator (e.g. Muslims in Sri Lanka who were victimized by both the state military and the rebel Liberation Tigers of Tamil Eelam (LTTE) and therefore could be part of both Sinhalese and Tamils' inclusive narratives of suffering, while other outgroups may be excluded (Haniffa 2007)? Or should inclusive narratives of suffering acknowledge the experiences of everyone involved in the conflict, including members of the perpetrator group? Depending on the scope of these narratives, we can expect different outcomes in the transitional justice process (see also Cohrs et al. 2015). Moreover, the inclusion of some groups' experiences may have seemingly paradoxical effects on intergroup outcomes, as discussed below where we explore the functions and consequences of inclusive victim narratives which hold both promises and pitfalls.

\section{The promise of inclusive victimhood: effects of inclusive victimhood on harmonious intergroup relations in the aftermath of conflict}

Several studies have demonstrated the prosocial effects of inclusive victim narratives on intergroup relations, both in ongoing conflicts and their aftermaths (Vollhardt 2015). For example, among Jewish Israelis, perceptions of shared experiences of loss and suffering with Palestinians due to the IsraeliPalestinian conflict predicted involvement in peace activism - above and beyond the effects of political ideology, demographic variables and personal experiences of victimization (Shnabel et al. 2013). Among Burundians, Rwandans and people living in the eastern Democratic Republic of the Congo (members of all ethnic groups in the respective regions), inclusive victim consciousness - specifically, agreement with the statement "[t]he victimization other groups in Rwanda [Burundi/DRC] have experienced is similar to what my group has experienced" - predicted various prosocial intergroup attitudes (Vollhardt and Bilali 2015). This included the self-reported willingness to speak up for outgroup members in need, and support for inclusive political leaders who consider all ethnic groups important, not just the participant's ingroup (Vollhardt and Bilali 2015). Overall, these studies in 
different contexts suggest that people who see that other groups involved in a conflict have also suffered are more likely to support views and actions that contribute to harmonious relations between different groups. Moreover, inclusive victim consciousness entails recognition of others' suffering, which is central to victim-centred measures of transitional justice in the aftermath of conflict (Auerbach 2009).

However, some studies also suggest limits to these effects of inclusive victim consciousness. One such study was conducted among Protestants and Catholics in post-accord Northern Ireland. For some participants, inclusive victim consciousness was associated with low levels of competitive victimhood. This is theoretically expected and in line with findings reported above. However, for other participants inclusive victim consciousness was, counterintuitively, associated with high levels of competitive victimhood (Cohrs et al. 2015). Moreover, the positive relationship between inclusive victim consciousness and support for reconciliation with the other group in the conflict was only present among participants who perceived low levels of competitive victimhood. Among participants who expressed both high levels of inclusive victim consciousness and high levels of competitive victimhood there was less support for reconciliation.

How can we explain these seemingly contradictory findings? Notably, in this particular study (Cohrs et al. 2015), the researchers assessed global inclusive victim consciousness rather than conflict-specific inclusive victim consciousness, asking participants whether they agreed or disagreed with statements such as "[m]any other groups in the world have suffered in similar ways to my group". This means that participants came up with their own choice of groups which they thought were similar to the ingroup in terms of experiences of oppression and victimization. Different participants may hence think of different groups when the items do not specify the context such as in conflict-specific victim consciousness. In a follow-up study (Cohrs et al. 2015, Study 2), content analysis of open-ended answers to the question of which groups participants were thinking of when they completed these items revealed two different levels of inclusivity. Some answers indicated a broad, universal sense of inclusivity where victims of different types of violence, with different positions of power in the conflict, and/or living in different parts of the world were described as having suffered in similar ways as the ingroup. For example, a Protestant participant in Northern Ireland noted: "Any group that has suffered as a result of violent conflict ... The trauma of violent conflict is the same for everyone" (Cohrs et al. 2015, Table 4). A Catholic participant similarly stated: "Both sides of any conflict or wars that are going on. I believe each side has its own stories to be told" (Cohrs et al. 2015). Conversely, other participants expressed a more selective sense of inclusive victim consciousness that was limited to other victim groups who had the same role or position of power in their respective conflict, and/or groups that had suffered from the same type of violence and oppression. This resulted in distinct answers for Catholic versus Protestant or 
Loyalist versus Nationalist participants, due to their group's role in, and dominant framing of, the conflict. For example, a Protestant participant -i.e. a member of the majority and high-power group in the conflict in Northern Ireland - wrote that they thought the following groups had suffered in similar ways as Protestants in Northern Ireland: "South African, Spanish, Iraqi communities ... They have been terrorized by anti-government political groups" (Cohrs et al. 2015, Table 4). In contrast, a self-identified Nationalist participant - i.e. a member of the minority with lower power in the conflict wrote that "Aborigines, Indian people, Black South Africans, American Indians, Palestinians [were similar to their own group] ... They have had their native countries taken and been murdered and persecuted" (Cohrs et al. 2015). These examples show the potential boundaries of inclusive victim consciousness which does not always include the other conflict party or all types of victim groups. Additionally, in some cases inclusive victim narratives may not even focus on the outgroup's interests and well-being, but instead may be used merely rhetorically to strengthen the ingroup's conflict position and strategic alliances (McNeill et al. 2017).

\section{The pitfalls of inclusive victimhood: power differences, silencing and demobilization}

Although the effects of inclusive narratives of suffering on establishing harmonious intergroup relations are fairly well documented, these processes may fail or even have conflict-enhancing consequences in post-conflict societies. What are often deemed to be "harmonious" intergroup relations may sometimes serve to maintain power differences and impunity, as well as mask inequality (Dixon et al. 2012; Saguy et al. 2009; see also Chapter 11 in this volume).

First, inclusive narratives of suffering can take on different forms as discussed earlier (i.e. selective or universal inclusive narratives; Cohrs et al. 2015) and can incorporate the experiences of different groups (e.g. adversary versus unrelated victim groups; Warner et al. 2014). Some forms of inclusive victim consciousness involve ignoring or silencing certain groups' experiences while privileging others. For example, overly inclusive victim narratives that are abstract and do not specify any group (e.g. "All Lives Matter"; "Crimes against Humanity") deny or diminish the unique experiences of victim groups (Vollhardt 2013; Leach and Allen 2017; Solomon and Martin 2019). Additionally, they can reduce empathy and raise undue expectations of forgiveness among the perpetrator group (Greenaway et al. 2012), while demobilizing collective action among the victim group demanding justice (Greenaway et al. 2011).

Furthermore, the outcome of inclusive victim narratives depends on the power of the group shaping the narrative. For high-power groups, narratives of suffering that incorporate both the ingroup and outgroup's suffering can be used strategically to justify ingroup violence and gain further legitimacy 
(McNeill and Vollhardt 2020). Inclusive narratives of suffering by high-power group members can also be viewed as a form of denial especially when the experiences of the (high-power) ingroup and low-power outgroup are equated (Twali et al. 2020). For example, in a speech to commemorate the 99th anniversary of the Armenian genocide, the Turkish Prime Minister Erdoğan declared that it was important to remember and understand this violence in the context of the "suffering for Turkish, Kurdish, Arab, Armenian and millions of other Ottoman citizens" during and after the First World War (Armenian Weekly 2014). Although on the surface this narrative appears to be inclusive, by strategically using it on the anniversary of a genocide that is actively denied by the Turkish state, Erdoğan was, in effect, denying the unique experience of the Armenian genocide and the role of the state in perpetrating the violence. Suffering is portrayed as a universal human experience during war, and more specifically as a shared experience of the region, without differentiating targeted violence intended to destroy a specific group and violence carried out in the context of military confrontations, which affected many groups in the region. Moreover, Turkey under Erdoğan continues to support policies that harm Armenian Turks and other minorities in Turkey (Bilali et al. 2019), showing that seemingly inclusive construals do not always go along with prosocial actions.

Similarly, in Sri Lanka, leaders from the Sinhalese majority group have historically utilized an inclusive narrative of suffering that focuses on terrorism (perpetrated by the LTTE) to delegitimize the political efforts of the less powerful Tamil minority, while legitimizing violence committed by the Sinhalese government and evading domestic and international criticism for human rights abuses committed in the process (Nadarajah and Sriskandarajah 2005). Specifically, since the end of the civil war in 2009, after the state's military secured a unilateral victory by annihilating the LTTE, an official ethos of triumph and an inclusive narrative of victimization has been maintained by the Sri Lankan state. This narrative focuses on defeating a terrorist organization that plagued the country for 26 years, causing mass destruction to both Sinhalese and Tamils alike (Jayakody and Penić 2021; Nadarajah 2018; Cronin-Furman 2020). However, this seemingly inclusive narrative is silent on claims that violence was carried out by state forces specifically against the Tamil minority or it can be used to legitimize such violence, thereby circumventing questions of accountability (Bala 2015; Cronin-Furman 2020).

As these examples show, inclusive victim consciousness does not always go along with prosocial attitudes or behaviours towards the other party/parties in the conflict. For example, among Jewish Israelis and Americans in the United States, inclusive narratives of suffering only increased support for policies benefiting Palestinians and Pakistanis, respectively, when participants were not concerned about losing support from other nations if they acknowledged the adversary's suffering (Adelman et al. 2016). Similarly, in a nationally representative survey study conducted in post-war Sri Lanka, different motives underlying inclusive victim consciousness predicted varied 
intergroup outcomes among the former parties to the war, particularly in relation to accountability (Jayakody and Penic 2021). Specifically, among the high-power Sinhalese ethnic group, inclusive victim consciousness predicted greater support for impartial prosecutions (conducted both domestically and with international involvement) of human rights violations of both parties only when they acknowledged crimes that their ingroup committed against the Tamil minority. In the absence of acknowledging such ingroup crimes, inclusive victim consciousness predicted less support for prosecutions, which appears to highlight the potentially strategic and defensive nature of inclusive victimhood claims made by the high-power majority (Jayakody and Penić 2021). These findings need to be understood in the context of what the justice process means for both parties. For the Tamil minority, the historical oppression suffered, and the way in which the war ended with high civilian casualties attributed to the actions of the state military, are important (OHCHR 2021). Accordingly, for Tamils, accountability measures are crucial and international involvement is necessary to ensure their fair implementation. Conversely, for many Sinhalese, the ending of the civil war and the violent separatist claims of the LTTE are important and accountability measures are seen as undermining the heroic actions of their state and military (see Lecamwasam 2016).

Among low-power groups, inclusive narratives that incorporate both the ingroup and high- power groups' suffering may inadvertently demobilize resistance efforts. For example, Kurds from Turkey who hold inclusive victimhood narratives were less likely to support policies that challenged Turkey's dominance (e.g. "bring lawsuits against Turkey in the European Court of Human Rights", "Kurds should support resistance organizations"; Adelman et al. 2016). Similarly, Sri Lankan Tamils who hold inclusive narratives of the suffering of all civilians irrespective of ethnicity or religion, are less likely to support impartial prosecutions of human rights violations (Jayakody and Penić 2021). These effects can, again, be explained by the lack of attention to power differences that overly inclusive victim narratives in asymmetric conflicts entail.

\section{Conclusion}

In conclusion, inclusive narratives of suffering are commonly found in postconflict societies and need to be considered in the transitional justice process. Several studies reviewed in this chapter indicate the potential of inclusive victim consciousness to foster reconciliation and justice and other outcomes commonly deemed to be positive in post-conflict settings. In line with important critiques of these approaches (see, for example, Chapter 11 in this volume; Penic et al. 2020), however, and of the focus on "harmony" as a goal of intergroup relations (e.g. Dixon et al. 2012; Saguy et al. 2009), we caution against uncritically utilizing (overly) inclusive narratives in post-conflict societies due to the risk of masking power differences between groups, legitimizing violence and silencing the narratives of individuals whose experiences 
are not included in their ingroup's official narrative. Instead of assuming that inclusive victim narratives are inherently positive and constructive, their specific function in each given context needs to be considered, given the power relations and status differences between the different actors involved. Transitional justice researchers and practitioners therefore have to engage in a nuanced, contextualized analysis of each conflict when constructing or drawing on inclusive narratives of suffering.

First, the scope of inclusive victimhood narratives that are to be utilized within transitional justice processes requires careful consideration. Social identities are complex and fluid, and it is easy to overlook nuances such as intersecting identities, intragroup disagreements concerning the boundaries of identities or the role of civilians' suffering versus that of combatants. Excluding certain experiences from seemingly inclusive narratives can endanger the success of the transitional justice processes that are to be implemented.

A second factor that can affect the success of a transitional justice process involves the specific framing of any given inclusive victimhood narrative. As stated before, when the framing is too abstract, it can diminish the uniqueness of a group's experience and ignore oppressive hierarchies, thereby contributing to the status quo and failing to address the roots of conflict. Inclusive victim narratives can also be more selective and, for example, focus on other groups who hold an analogous role to the ingroup, but within a different conflict setting. These narratives can take into account the interests and well-being of other groups to varying degrees and/or be used strategically to defend the ingroup's initial position. Hence, one might infer that inclusive narratives of suffering will only be successful in the transitional justice process if they are nuanced and effectively framed. As high-power groups often have the upper hand in framing narratives, the role of alternative media, education and other independent civil society organizations is important in creating, disseminating and contributing to the perception that nuanced inclusive victim narratives are morally right and widely accepted in a given society (Bilali 2014).

Finally, there are clear ethical boundaries and limits to inclusive narratives, such as when perpetrator groups in asymmetric conflicts and genocides attempt to construct inclusive narratives to relativize atrocities, justify impunity or maintain oppressive social relations. In such cases, resistance against inclusive narratives of victimization is informative about the political controversies in a conflicted setting (see Chapter 11 in this volume). Additionally, in such contexts resistance against inclusive victim narratives can be morally just as important as it might be to promote them in some other contexts.

\section{References}

Abeyratne, Sirimal. "Economic roots of political conflict: The case of Sri Lanka". The World Economy, vol. 27, no. 8, 2004, pp. 1295-1314, doi:10.1111/j.14679701.2004.00645.x. 
Adelman, Levi, Bernhard Leidner, Helin Ünal, Eman Nahhas, and Nurit Shnabel. "A whole other story: Inclusive victimhood narratives reduce competitive victimhood and intergroup hostility". Personality and Social Psychology Bulletin, vol. 42, no. 10, Oct. 2016, pp. 1416-1430, doi:10.1177/0146167216662868.

Armenian Weekly. "Erdogan Issues Statement on 'Events of 1915". Armenian Weekly, 23 April 2014, https://armenianweekly.com/2014/04/23/erdogan-issues-sta tement-events-1915/. Accessed 28 February 2021.

Auerbach, Yehudith. "The reconciliation pyramid: A narrative-based framework for analyzing identity conflicts". Political Psychology, vol. 30, no. 2, 2009, pp. 291-318, doi:10.1111/j.1467-9221.2008.00692.x.

Bala, Mytili. "Transitional justice in Sri Lanka: Rethinking post-war diaspora advocacy for accountability". DePaul Int'l Human Rights Law Journal, vol. 1, no. 1, 2015, pp. 1-47, https://via.library.depaul.edu/ihrlj/vol1/iss1/2.

Bilali, Rezarta. "Between fiction and reality in post-genocide Rwanda: Reflections on a social-psychological media intervention for social change". Journal of Social and Political Psychology, vol. 2, no. 1, 2014, pp. 387-400, doi:10.5964/jspp.v2i1.288.

Bilali, Rezarta, Yeshim Iqbal, and Samuel Freel. "Understanding and counteracting genocide denial". Confronting humanity at its worst: Social psychological perspectives on genocide, edited by Leonard Newman, New York, Oxford University Press, 2019, pp. 284-311, doi:10.1093/oso/9780190685942.003.0011.

Christopher, Anthony John. "Divide and Rule': The impress of British separation policies”. Area, vol. 20, no. 3, 1988, pp. 233-240, www.jstor.org/stable/20002624.

Cohrs, J. Christopher, Andrew McNeill, and Johanna Ray Vollhardt. "The two-sided role of inclusive victimhood for intergroup reconciliation: Evidence from Northern Ireland". Peace and Conflict: Journal of Peace Psychology, vol. 21, no. 4, 2015, pp. 634-647, doi:10.1037/pac0000141.

Cole, Elizabeth R. "Intersectionality and research in psychology". American Psychologist, vol. 64, no. 3, 2009, pp. 170-180, doi:10.1037/a0014564.

Corry, Avigail, and Sulaiman Khatib. "Why we, Palestinians and Israelis, insist on mourning our dead together". The Nation, 2019, www.thenation.com/article/archi ve/palestinians-israelis-mourning-our-dead-together/.

Cronin-Furman, Kate. "Human rights half measures: Avoiding accountability in postwar Sri Lanka”. World Politics, vol. 72, no. 1, 2020, pp. 121-163, doi:10.1017/ S0043887119000182.

de Silva, C. R. "Sinhala-Tamil ethnic rivalry: The background". From independence to statehood: Managing ethnic conflict in five African and Asian states, edited by R. B. Goldmann and A. J. Wilson, New York, St. Martin's Press, 1984, p. 116.

DeVotta, Neil. "Control democracy, institutional decay, and the quest for Eelam: Explaining ethnic conflict in Sri Lanka”. Pacific Affairs, vol. 73, no. 1, 2000, pp. 55-76, doi:10.2307/2672284.

DeVotta, Neil. "From ethnic outbidding to ethnic conflict: The institutional bases for Sri Lanka's separatist war". Nations and Nationalism, vol. 11, no. 1, 2005, pp. 141159, doi:10.1111/j.1354-5078.2005.00196.x.

DeVotta, Neil. "Illiberalism and ethnic conflict in Sri Lanka". Journal of Democracy, vol. 13, no. 1, 2002, pp. 84-98, doi:10.1353/jod.2002.0004.

Dixon, John, Mark Levine, Steve Reicher, and Kevin Durrheim . "Beyond prejudice: Relational inequality, collective action, and social change revisited". The Behavioral and Brain Sciences, vol. 35, no. 6, 2012, pp. 451-466, doi:10.1017/ s0140525x12001550. 
Dovidio, John F., Samuel L. Gaertner, and Tamar Saguy. "Commonality and the complexity of 'we': Social attitudes and social change". Personality and Social Psychology Review, vol. 13, no. 1, 2009, pp. 3-20, doi:10.1177/1088868308326751.

Elcheroth, Guy, and Stephen Reicher. Identity, violence and power: Mobilizing hatred, demobilising dissent. London, Palgrave Macmillan, 2017.

Ferguson, Neil, Mark Burgess, and Ian Hollywood. "Who are the victims? Victimhood experiences in postagreement Northern Ireland". Political Psychology, vol. 31, no. 6, 2010, pp. 857-886, doi:10.1111/j.1467-9221.2010.00791.x.

Garagozov, Rauf. "Painful collective memory: Measuring collective memory affect in the Karabakh conflict." Peace and Conflict: Journal of Peace Psychology, vol. 22, no. 1, 2016, pp. 28-35, doi:10.1037/pac0000149.

Greenaway, Katharine H., Winnifred R. Louis, and Michael J.A. Wohl. "Awareness of common humanity reduces empathy and heightens expectations of forgiveness for temporally distant wrongdoing". Social Psychological and Personality Science, vol. 3, no. 4, 2012, pp. 446-454, doi:10.1177/1948550611425861.

Greenaway, Katharine H., Emerald A. Quinn, and Winnifred R. Louis. “Appealing to common humanity increases forgiveness but reduces collective action among victims of historical atrocities". European Journal of Social Psychology, vol. 41, no. 5, 2011, pp. 569-573, doi:10.1002/ejsp.802.

Greenwood, Ronni Michelle. "Intersectional political consciousness: Appreciation for intragroup differences and solidarity in diverse groups". Psychology of Women Quarterly, vol. 32, no. 1, 2008, pp. 36-47, doi:10.1111/j.1471-6402.2007.00405.x.

Hameiri, Boaz, and Arie Nadler. "Looking backward to move forward: Effects of acknowledgment of victimhood on readiness to compromise for peace in the protracted Israeli-Palestinian conflict". Personality and Social Psychology Bulletin, vol. 43, no. 4, 2017, pp. 555-569, doi:10.1177/0146167216689064.

Haniffa, Farzana. "Muslims in Sri Lanka's ethnic conflict". Polity: A Journal for Peace, Democracy and Pluralism, vol. 4, no. 2, 2007, pp. 16-18.

Hornsey, Matthew J., and Michael A. Hogg. "Assimilation and diversity: An integrative model of subgroup relations". Personality and Social Psychology Review, vol. 4, no. 2, 2000, pp. 143-156, doi:10.1207/S15327957PSPR0402_03.

Jayakody, Sumedha, and Sandra Penić. The influence of an inclusive victimhood narrative on support for prosecutions in postwar Sri Lanka. Manuscript in preparation, 2021.

Leach, Colin Wayne, and Aerielle M. Allen. "The social psychology of the Black Lives Matter meme and movement". Current Directions in Psychological Science, vol. 26, no. 6, 2017, pp. 543-547, doi:10.1177/0963721417719319.

Lecamwasam, Nipunika. "Transitional justice in post-war Sri Lanka: Dilemmas and prospects". Polity: A Journal for Peace, Democracy and Pluralism, vol. 7, no. 1, 2016, pp. 14-17.

McNeill, Andrew, Samuel Pehrson, and Clifford Stevenson. "The rhetorical complexity of competitive and common victimhood in conversational discourse". European Journal of Social Psychology, vol. 47, no. 2, 2017, pp. 167-179, doi:10.1002/ ejsp. 2255.

McNeill, Andrew, and Johanna Ray Vollhardt. "We all suffered!: The role of power in rhetorical strategies of inclusive victimhood and its consequences for intergroup relations". The Social Psychology of Collective Victimhood, edited by Johanna Ray Vollhardt, New York, Oxford University Press, 2020, pp. 337-358, doi:10.1093/oso/ 9780190875190.003.0016. 
Nadarajah, Suthaharan. "The Tamil proscriptions: Identities, legitimacies, and situated practices". Terrorism and Political Violence, vol. 30, no. 2, 2018, pp. 278-297, doi:10.1080/09546553.2018.1432214.

Nadarajah, Suthaharan, and Dhananjayan Sriskandarajah. "Liberation struggle or terrorism? The politics of naming the LTTE". Third World Quarterly, vol. 26, no. 1, 2005, pp. 87-100, doi:10.1080/0143659042000322928.

Nair, Rashmi, and Johanna Ray Vollhardt. "Intersectional consciousness in collective victim beliefs: Perceived intragroup differences among disadvantaged groups". Political Psychology, May2019, doi:10.1111/pops.12593.

Nair, Rashmi, and Johanna Ray Vollhardt. "Intersectionality and relations between oppressed groups: Beliefs of intersectional differences and commonalities and their policy implications". Journal of Social Issues, vol. 76, no. 4, 2020, pp. 993-1013.

Noor, Masi, Nurit Shnabel, Samer Halabi, and Arie Nadler. "When suffering begets suffering: The psychology of competitive victimhood between adversarial groups in violent conflicts". Personality and Social Psychology Review, vol. 16, no. 4, 2012, pp. 351-374, doi:10.1177/1088868312440048.

Noor, Masi, Johanna Ray Vollhardt, Silvia Mari, and Arie Nadler. "The social psychology of collective victimhood”. European Journal of Social Psychology, vol. 47, no. 2, 2017, pp. 121-134, doi:10.1002/ejsp.2300.

Office of the United Nations High Commissioner for Human Rights (OHCHR). Promotion reconciliation, accountability and human rights in Sri Lanka. 2021, www. ohchr.org/Documents/Countries/LK/Sri_LankaReportJan2021.docx.

Penić, Sandra, Johanna Ray Vollhardt, and Stephen Reicher. "Reconciliation versus justice? It depends on the context: The role of symmetric and asymmetric violence in predicting postconflict attitudes". Social Psychological and Personality Science, Apr. 2020, doi:10.1177/1948550620915064.

Reicher, Stephen, Stephen Reicher, Clare Cassidy, Ingrid Wolpert, Nick Hopkins, and Mark Levine. "Saving Bulgaria's Jews: An analysis of social identity and the mobilisation of social solidarity". European Journal of Social Psychology, vol. 36, no. 1, Jan./Feb. 2006, pp. 49-72, doi:10.1002/ejsp.291.

Rosenthal, Lisa. "Incorporating intersectionality into psychology: An opportunity to promote social justice and equity". American Psychologist, vol. 71, no. 6, 2016, pp. 474 485, doi:10.1037/a0040323.

Saguy, Tamar, Nicole Tausch, John F. Dovidio, and Felicia Pratto. "The irony of harmony: Intergroup contact can produce false expectations for equality". Psychological Science, vol. 20, no. 1, 2009, pp. 114-121, doi:10.1111/j.14679280.2008.02261.x.

Schwarz, Walter. The Tamils of Sri Lanka. 2nd ed., London, Minority Rights Group, 1983.

Shnabel, Nurit, Yaniv Belhassen, and Shira Mor. "From victimhood to peace activism: The potential role of personal loss and inclusive victim beliefs". Group Processes \& Intergroup Relations, vol. 21, no. 8, 2017, pp. 1144-1154, doi:10.1177/ 1368430217699463.

Shnabel, Nurit, Samer Halabi, and Masi Noor. "Overcoming competitive victimhood and facilitating forgiveness through re-categorization into a common victim or perpetrator identity". Journal of Experimental Social Psychology, vol. 49, no. 5, 2013, pp. 867-877, doi:10.1016/j.jesp.2013.04.007.

Solomon, Johanna, and Adam Martin. "Competitive victimhood as a lens to reconciliation: An analysis of the Black Lives Matter and Blue Lives Matter 
movements". Conflict Resolution Quarterly, vol. 37, no. 1, 2019, pp. 7-31, doi:10.1002/crq.21262.

Twali, Michelle Sinayobye. "The role of identity transformations in comparative victim beliefs? Evidence from South Sudanese diaspora". Journal of Social and Political Psychology, vol. 7, no. 2, 2019, pp. 1021-1043, doi:10.5964/jspp.v7i2.865.

Twali, Michelle, Sinayobye, Boaz, Hameiri, Johanna Ray, Vollhardt, and Arie Nadler. "Experiencing acknowledgment versus denial of the in-group's collective victimization." The social psychology of collective victimhood, edited by Johanna Ray Vollhardt, New York, Oxford University Press, 2020, doi:10.1093/oso/9780190875190.003.0014.

Vollhardt, Johanna Ray. "Collective victimization". The Oxford handbook of intergroup conflict, edited by Linda Tropp, New York, Oxford University Press, 2012, pp. $136-157$.

Vollhardt, Johanna Ray. "Crime against humanity' or 'crime against Jews'? Acknowledgment in construals of the Holocaust and its importance for intergroup relations". Journal of Social Issues, vol. 69, no. 1, 2013, pp. 144-161, doi:10.1111/ josi.12008.

Vollhardt, Johanna Ray. "Inclusive victim consciousness in advocacy, social movements, and intergroup relations: Promises and pitfalls". Social Issues and Policy Review, vol. 9, no. 1, 2015, pp. 89-120, doi:10.1111/sipr.12011.

Vollhardt, Johanna Ray. "The role of victim beliefs in the Israeli-Palestinian conflict: Risk or potential for peace?" Peace and Conflict, vol. 15, no. 2, 2009, pp. 135-159, doi:10.1080/10781910802544373.

Vollhardt, Johanna Ray, and Rezarta Bilali. "The role of inclusive and exclusive victim consciousness in predicting intergroup attitudes: Findings from Rwanda, Burundi, and DRC". Political Psychology, vol. 36, no. 5, 2015, pp. 489-506, doi:10.1111/pops.12174.

Vollhardt, Johanna Ray, and Michelle Sinayobye Twali. "Emotion-based reconciliation requires attention to power differences, critical consciousness, and structural change”. Psychological Inquiry, vol. 27, no. 2, 2016, pp. 136-143, doi:10.1080/ 1047840X.2016.1160762.

Vollhardt, Johanna Ray, et al. "Beyond comparisons: The complexity and contextdependency of collective victim beliefs". Manuscript under revision, 2021.

Warner, Ruth H., Michael J.A. Wohl, and Nyla R. Branscombe. "When do victim group members feel a moral obligation to help suffering others?" European Journal of Social Psychology, vol. 44, no. 3, 2014, pp. 231-241, doi:10.1002/ejsp.2010. 


\title{
13 How crowds transform identities
}

\author{
Yasemin Gülsüm Acar and Stephen Reicher
}

\section{Introduction}

In this chapter we address the role of crowd events in reshaping the boundaries of group inclusion and exclusion. In this way we hope to shed some new light on the process of reconciliation - of how it can be facilitated and how it can be undermined through the dynamics of mass action.

Empirically, our discussion is based on two major events in the recent history of Turkey, both of which were centred on the question of the nature of Turkish nationhood. We start with the 2013 Gezi Park protests which sought to assert a new vision of Turkey and, in so doing, brought together groups who, previously, had been deeply (and, at times, violently) opposed. Kurds stood side by side with nationalist Turks, even after decades of assimilationist policies and conflict, Alevis with Sunnis, despite discrimination and violence, and LGBT activists, who were often maligned and marginalized by any or all of these groups. We then turn to the post-2016 coup "Democracy Watches" gatherings, which also brought people together under the badge of nationhood but which excluded many, such as the Kurds, who were defined as a threat, as were those who sympathized with them - or at least opposed repressive measures being taken against them. This contributed to both the deepening and the broadening of conflict, where previously there had been a process of reconciliation.

At first glance, it might seem rather strange to address the issue of reconciliation through the prism of crowd psychology, and even stranger to suggest that crowds might be a resource for reconciling opposed groups. After all, crowds are traditionally associated with chaos and discord. According to Gustave Le Bon's (1895) classic text, they undermine reason and restraint and lead ordinarily rational individuals into frenzied extremes of destruction. What on earth could crowds have to do with reconciliation?

\section{Crowds and social identity}

In order to answer this question, we need to rethink the nature of crowd psychology and the process of reconciliation - the link between the two lying

DOI: $10.4324 / 9781003167280-17$ 
in the centrality of social identity processes in both. The concept was introduced to social psychology through the work of Henri Tajfel and John Turner (1986), which posits that at different times, different aspects of the self-system will be salient (in church, religious identity; at a rally, political identity, etc.). Moreover, when different identities are salient, we will behave in terms of the different beliefs, understandings and priorities associated with them: reverent when religious, raucous when political. Over the past four decades, these insights have been applied to the analysis of crowd action (Drury and Reicher 2020; Reicher 1984, 2001, 2017). Not all physical crowds are psychological groups. Sometimes they consist of individuals who have no sense of commonality with others - people crowded onto a train, say. But one sees the contrast when something happens which creates a sense of shared social identity among them - the train breaks down and people begin to view themselves and others as aggrieved commuters. Behaviour changes, people become closer, united in a shared grievance against the train company (Neville et al. 2020).

What happens in such psychological crowds is not that people lose identity, and hence lose control, but rather shift from personal to social identity. Correspondingly, they do not lose all their standards or lose control over their behaviour. Rather, control shifts to collective beliefs, understandings and priorities. This accords with historical studies which show that crowds, including the most extreme and violent crowds, don't do just anything. Rather, crowd action is socially patterned, reflecting collective beliefs, revealing perceptions of who is friend, who is foe, and how they should be treated (Davis 1973; Thompson 1971).

However, it is not just that crowd action reflects social identity, it also serves to create and change social identities (Drury and Reicher 2009; Reicher 1996). One recurring pattern, for instance, arises as a psychologically disparate crowd (say a protest comprising many different groups, some even actively opposed to one another) is treated as if they were all the same by external agents such as the police. This leads to a sense of common fate and can unite those previously opposed within a single emergent category (e.g. Drury and Reicher 2000; Stott and Drury 2000).

Moreover, group identities can be transformed not only for those involved but also for those who observe crowds. As Benedict Anderson (1983) famously argued, large categories like the nation are always "imagined communities", since it would be impossible for all members to assemble together. However, crowds that represent the nation (and other such extended categories) can be seen as the imagined community made manifest.

At the same time, crowd events can be seen as performative acts, deliberately structured in such a way as to create and sustain specific constructions of social identity. This is particularly clear from the literature on festivals and commemorations (e.g. Gillis 1994) which illustrates how these are carefully staged in order to define social relations within the group (who belongs, who takes precedence and who represents us) and between groups. Indeed, where 
understandings of the group change, or where different versions of the group compete at the same time, these are reflected in the changing choreography of collective events (Gelvin 1998; Ozouf 1991).

\section{Reconciliation and social identity}

In this chapter, then, we join together the study of how crowds create social identities with the study of how social identities impact intergroup relations both in terms of reconciling those previously opposed to one another and dividing those previously united. As stated above, we do this in the context of Turkey, a country whose sense of nationhood has always been troubled and contested - and which, as a consequence, remains deeply divided on multiple axes (Poulton 1997). Turkey is split geographically, between a largely rural, traditional and devout Sunni Muslim population and the more urban, modern and secular one. It is also split ethnically, with a long-standing conflict between the state and Kurds, and on religious grounds between Alevis, an often unrecognized heterodox Islamic minority, and the majority Sunni Muslims. Furthermore it is split ideologically, with the political left and right having violently clashed most notably in the years leading up to the 1980 coup.

We examine two of the largest crowd events in recent Turkish history: the 2013 Gezi Park protests and the post 2016-coup "Democracy Watches" gatherings. Both events were bound up with defining what it means to be a citizen of Turkey and involved both elements of unification and of division. However, in contrast to what went before, what was striking in the Gezi Park protests was the way in which they included and brought together previously disparate groups within their definition of nationhood. While reconciliation may not have been the objective of the protests, we discuss how the this provided an opportunity for groups who have long been disconnected and in many cases in conflict with each other (such as Muslim faith groups and LGBT activists) to reconcile.

On the other hand, what was striking about the "Democracy Watches" gatherings, which followed the failed attempt by the military to oust President Recep Tayyip Erdoğan, was the way that they were deliberately aimed at excluding particular groups which, previously, had been accepted as part of the nation. We discuss how this reignited conflict between groups previously involved in a process of reconciliation and also widened the scope of this conflict.

We explore how these outcomes came about by drawing on some of our previous (i.e. Acar and Uluğ 2016; Uluğ and Acar 2015, 2018), and ongoing (i.e. Acar and Reicher manuscript in preparation) studies. The Gezi Park research consists of semi-structured interviews with protest participants in 2013-14 (Acar and Uluğ 2016; Uluğ and Acar 2015), and, later, discussions on the outcomes of the protests in 2016 (Ulug and Acar 2018). The ongoing research consists of analysis of archival media footage of events, as well as 
participant observation at one of the "Democracy Watches" gatherings in Taksim on 21 July 2016 (Acar and Reicher manuscript in preparation; Acar and Sandal Önal forthcoming).

\section{The Gezi Park protests}

\section{The events at Gezi Park}

In 2013, Prime Minister Erdoğan's government initiated a project aimed at redeveloping the Taksim Square area in the centre of İstanbul. Part of pedestrianizing Taksim involved plans to remove Gezi Park, one of the few remaining green spaces in the centre of the European side of the city and replacing it with a building in the style of an Ottoman-style artillery barracks. Strong objections were made about the proposed artillery barracks, as they would remove the Gezi Promenade and also harm mature trees in the area. Furthermore, that the barracks would house a shopping mall was also met with objections, based on the reason that the park was an area used for public recreation being replaced with a consumerist space.

There was also a third, ideological, objection. For many liberals and leftists in Turkey, who claim the heritage of Mustafa Kemal, the founder of the contemporary nation, Taksim is an urban space representing a modern, postOttoman Turkey. In contrast to old İstanbul's restrictive traditional norms, Taksim became the place where men and women could co-exist and participate equally in a secular atmosphere (Gül et al. 2014). The ideological struggles in the 1960s and 1970s brought another layer of symbolism to Taksim, as it became synonymous with socialist ideology and the labour movement. Taksim has, since the 1950s, been the preferred location for political rallies, public meetings and demonstrations. The May Day demonstration on 1 May 1977 were a turning point in Turkish political history. An unknown gunman concealed in a nearby building killed 34 people and injured hundreds of others. The events created a strong symbolic link between Taksim and the leftists in Turkey.

Therefore, the government's intention to reoccupy the square was considered provocation enough, to do so with the construction of a building along pre-modern militaristic lines was even worse and seen as an attempt to erase the symbolic meaning of the square. In occupying Gezi Park, the protesters were doing more than simply opposing a specific urban development. They were defending their vision of a modern nation against what they perceived as Erdoğan's archaic authoritarian vision.

On 28 May 2013, a small group of protesters camped in the park and refused to leave. Images of the police burning protesters' tents and using tear gas to disperse them spread quickly across social media and brought attention to the protests. The size of the protests grew until 31 May when, after an early morning police raid, thousands began to gather in Taksim to protest. Over 1,000 protesters marched on foot over the Bosphorus Bridge from the 
Asian side to the European side of İstanbul to join protesters in Taksim and neighbouring Beşiktaş. On 1 June, the protests spread to Ankara and İzmir, where protesters assembled to show solidarity with those in İstanbul. After being met with police resistance these became centres of occupation in their own right. In the following days, people across the country - in total between 2.5 and 3.5 million - took to the streets in solidarity and to raise their voices regarding the plans for the park. The focus of the protests quickly shifted from environmental and urban policies to a general opposition to the ruling Adalet ve Kalkınma Partisi (AKP - Justice and Development Party) and to then Prime Minister Recep Tayyip Erdoğan.

The park and surrounding Taksim Square remained an occupied space until 11 June, when police entered the square in the harshest crackdown since the start of the movement. On 15 June, the police entered Gezi Park itself and cleared out the protesters, using, as a pretext, a meeting by Prime Minister Erdoğan in another part of İstanbul. After the eviction, there was an increase in protests and demonstrations, with events occurring on and off every weekend throughout mid-2013.

The Gezi Park protests were unique in Turkey for their ability to bring together people who spanned the country's traditional divides, oftentimes with the only common ground being their opposition to Erdoğan and his party. Religious and ethnic minorities (i.e. Kurds, Alevis, Armenians) had a strong presence at the protests, as did LGBT activists. Socialist and the main opposition parties were also present, with some more nationalist groups represented as well.

\section{Common experience, common repression and the production of unity}

The combination of opposition to the AKP, the contextual factors of ongoing events and discontent with government policy, and the police brutality in the streets brought different groups together who oftentimes did not see one another as part of a common community. In some of our previous work (Acar and Uluğ 2016; Acar 2018; Uluğ and Acar 2015, 2018, 2019) Gezi Park protesters described the way that participation in the protests changed their perception of others. A study involving 34 participants from various groups, political parties or institutions pointed to multiple instances of common fate and resultant experiences of togetherness.

At the most basic level, the mere experience of protesting together with others blurred previous boundaries between "us" and "them" and created a common category of protester:

Many different segments came together. You no longer had LGBT, trans, Armenian, CHP, right-wing, or right-wingers. There were a lot of people there to show their reaction to the violent, wild, fascist attitudes of the police or the state. 
In part, this was a process of living in proximity and discovering commonalities that overcame previous assumptions of difference -between feminists and Muslim groups, say, as shown in the following: "Meeting the anti-capitalist Muslims was really interesting ... Iftar meals, the earth tables were unbelievable ... Even though I don't fast, I really looked forward to breakfast because I was going to their earth table" (feminist activist cited in Acar and Ulug 2016). It also came out of the need for mutual support to cope with the basic conditions of the protest. As Ulug and Acar (2018, 2019) show, Gezi Park functioned as an open-air commune. Tents and blankets were shared. Food and water were distributed and a variety of facilities, including a medical clinic and library, were established by the participants. The park and camp area were cleaned by protesters. Lists of items that were needed were posted in the park and on social media, and items would be brought by supporters. If such mutual support is, as we argued above, a consequence of shared social identity, it equally functions as an antecedent, cementing a sense of "we are in this together".

What is more, the various groups managed to work together. That they created an effective and harmonious society in miniature, even with very limited resources, was a source of shared pride which further consolidated a shared sense of identity, mutual respect and transcendence of previous differences:

We showed the world a model of democracy there. "Democracy can be such a thing", we said. We showed "we can go hand in hand with each other, even though we are not like each other, we can exist together in a society by respecting each other".

(Trans activist cited in Uluğ and Acar 2015)

However, while these mutual efforts to survive in harsh times were important, they were framed by the context of repression they had all experienced at the hands of the police. Common repression led to a common category of resistors even among unlikely combinations. Sometimes, this process brought together nationalist Turks and Kurds - previously opposed in armed conflict. As the nationalists found themselves, for the first time, on the receiving end of state brutality, they began to doubt their own previous understandings, to empathize with the Kurdish experience of repression and to question their support for conflict:

Of course, we experienced really interesting things. The gas bombs that were thrown there, the injured people, the oppression; against all this, for example, nationalist Turks would come and say to us "We never understood you, you've experienced this oppression for years ... there were also those who compared themselves to us, "Here in İstanbul's centre, they are calling us the "enemy". I wonder what happened in the east and we didn't see it?"

(Kurdish activist cited in Acar and Uluğ 2016) 
So, whether Muslim or LGBT, nationalist or Kurdish - whichever side of Turkey's entrenched divides one had occupied outside Gezi Park - within the park itself, the protesters were equally subject to police violence and hence came to be on the same side.

This sense of unity in diversity (in face of common adversity) was not just an idea, it was a felt experience. It was embedded in the sensual fabric of the protests. One only had to look at them. The different parties, organizations and groups all had their various flags and banners, the colours that represented them, hanging in the park and on the front of the Atatürk Cultural Centre at the edge of Taksim Square. Walking through the park you could see shades of red of various communist groups, the purple of feminist organizations, combinations of green, red, and yellow for pro-Kurdish groups, not to mention the LGBT rainbow flag and anarchists' black. When reflecting on the protests, some participants would refer to the "many colours of Gezi" and how this patchwork of people came together and coalesced in a common cause.

What is more, the experience was not ephemeral. It did not dissipate as soon as people were evicted from the square. In the years following the protests, many activists still referred to the experiences of togetherness they had at Gezi as a point at which other groups began to embrace their groups' goals for social justice, as well as the new connections that were formed.

We always kept other organizations, other social movements at arm's length. We kind of went along with the feminist movement, the antimilitary movement, ecologic, women's movement, but going arm in arm to a protest is something else ... It's like having a roommate. You can be really good friends with someone but you can have problems when you move in together. [But] at Gezi, we became "roommates" with at least 30 social movements.

(LGBTI activist cited in Uluğ and Acar 2018)

In sum, the Gezi Park protests provide a powerful example of how crowd events can transform the identities of participants. This was achieved through creating a conception of nationhood which, although being rooted in opposition to the AKP government as pursuing an anti-national course, did bring together groups that had previously been opposed to one another and in some cases were even in open conflict with each other.

Of course, this is not a reconciliation process in the conventional sense. No one set out to get on better with anyone. Groups did not go to Gezi Park in order to change their social relations with each other. They didn't evaluate the event in terms of the effects of these relations. But precisely for these reasons Gezi Park is particularly interesting to understand informal, emergent and bottom-up dynamics of reconciliation.

At this point, though, a caveat is in order. We must beware of going from universal condemnation of crowds to universal praise. For, as we shall see 
next, crowds don't only redefine categories to include those who were previously excluded and reverse processes of conflict between these groups. They can equally redraw the boundaries to exclude those who were previously included and hence invigorate intergroup conflict.

\section{The 2016 post-coup "Democracy Watch" gatherings}

\section{The July 2016 coup attempt}

On 15 July 2016, a faction of the Turkish Armed Forces, calling themselves the Yurtta Sulh Konseyi (Peace at Home Council), attempted a coup d'état against Turkey's state institutions. The Peace at Home Council coordinated operations in major cities and key locations in an attempt to remove President Erdoğan. Within a couple of hours, President Erdoğan, who was on holiday in southwest Turkey at the time, gave a FaceTime interview on CNN Türk, during which he called upon his supporters to take to the streets in defiance of the military-imposed curfew. His statement and encouragement to take to the streets was reiterated by other members of his government, including the mayor of Ankara, and soon thousands responded by opposing the military presence around İstanbul and Ankara.

Within a matter of hours, the crowds defeated the coup, and soldiers who took part in the coup attempt surrendered on the Bosphorus Bridge in İstanbul. The AKP regained control of the government and blamed the exiled religious leader Fethullah Gülen and his followers for instigating the coup. But regaining control came at a high price: the event is considered the bloodiest coup attempt in Turkey's political history; 241 people were killed and 2,194 were injured. Following the coup attempt, the government issued a state of emergency that lasted approximately two years. During emergency rule, the government enacted 32 emergency decrees, removing over 100,000 people from public service, and permanently closed nongovernmental organizations, universities and other entities with supposed ties to Gülen or who were otherwise in opposition to the AKP.

\section{The "Democracy Watch" gatherings}

In the weeks following the coup attempt, the government encouraged citizens to continue their presence on the streets with so-called Democracy Watch gatherings organized in major centres and squares in İstanbul and Ankara, including Taksim Square in İstanbul. These nightly meetings were considered a continuation of the civil resistance that took place during the night of 15 July. In contrast with the Gezi Park protests, the Democracy Watches had strong institutional support; food and water were distributed, portable toilets were brought to Taksim Square, and numerous stages were erected, with local radio personalities and others leading the festivities every evening. 
On 7 August 2016, the AKP, together with two other major political parties, the Cumhuriyet Halk Partisi (CHP - Republican People's Party) and the Milliyetçi Hareket Partisi (Nationalist Movement Party), held an anti-coup rally in Yenikap1, İstanbul. Notably, the pro-Kurdish Halkların Demokratik Partisi (HDP - Peoples' Democratic Party) was not invited. The Turkish media announced that millions of people were in attendance at the meeting, although no official estimate exists. President Erdoğan spoke to attendees at Yenikapı Square from a large stage draped with national flags and images of Erdoğan and the founder of the Turkish Republic, Mustafa Kemal Atatürk. Rather than party banners, Erdoğan encouraged participants to carry Turkish flags. In his two-hour speech, Erdoğan extolled the virtues of the citizens who took to the streets on the night of the coup attempt, praising them and their sacrifices.

In contrast to the many different types of flags and banners on display in Taksim during the Gezi Park protests, during the "Democracy Watch" gatherings, the only symbol in Taksim Square was the Turkish flag. One flag took up the entire space of the Atatürk Cultural Centre, with wording that read "Sovereignty belongs to the nation." Beyond the "Democracy Watch" gatherings, this message of unifying under a single national flag could be found all across İstanbul. After the coup attempt, a message on the subway read:

Dear İstanbulites ... Being one and being together, giving your heart and soul in hand, we showed the power of being a nation to the whole world, together we have protected our democracy, our freedom and our homeland. Now is the time for our flag to wave proudly, let's hang our moon and star flag from our workplaces and our homes, and let's be one and be together in its shadow.

(Acar and Sandal Önal forthcoming)

The AKP government also put the coup attempt and the resistance against it into a historical framework. The "Democracy Watch" gatherings utilized familiar tropes related to Turkey's 1919-23 War of Independence, creating and perpetuating the myth of a "second founding" after 2016 (Konya 2020). Therefore, the crowds that rose up to prevent the coup were lauded as saviours of the country and of democracy. They were consistently honoured in the national media through personal stories and the traumas that were experienced on the night of the attempted coup. Those who died received official "martyr" status, and the resistance of that night became a war comparable to the American and French Revolutions (Taş 2018). Erdoğan stated that " 15 July is the second War of Independence for the Turkish nation. Let us know it like that. They [threatened] us with Sèvres in 1920 and persuaded us to [accept] Lausanne in 1923' (Hürriyet Daily News 2016). In doing so, he created a narrative that continued the one that created the Turkish Republic, whereby Western Imperialism attempts to "destroy" the Turkish state, but it 
is the people that resist and prevent its destruction. Turkish history texts were revised to include the events, and national landmarks and squares were renamed to keep the memory of the coup attempt alive.

Critically, the notion of a "coup" relies not only on an external enemy but also on an internal enemy. It therefore serves not only to bring the nation together against foreign foes, but also against those within the nation who are characterized as the dupes or collaborators of these foes. One should note, though, that in different coups the nature of the internal enemy (and hence the identity of those who need to be excluded) changes. During the 1980 coup the target was the "anarchists" (referring mostly to young politicized leftists). In this case the focus was the "terrorists". In practice this meant anyone who opposed the AKP and President Erdoğan. Hence, although the ostensible focus of the event was one of inclusion and unification within the nation, the Democracy Watches served to narrow the definition of the category so as to exclude many groups which, previously, could be included as Turkish.

So, while at one level the Democracy Watches and the Gezi Park protests were similar in that they both involved elements of both inclusion and exclusion, at another level they were diametrically opposed. The Gezi Park protests were ostensibly an act of opposition (rejecting the AKP as representing the nation) but one that brought together opposed groups in an extended definition of the nation. The Democracy Watches were ostensibly acts of unification (bringing the nation together after experiencing trauma) but nevertheless excluded previously reconciled groups from a narrowed definition of the nation.

This contrast was visible at many levels. We have seen how Gezi Park was a riot of different colours and styles and flags manifesting "unity in difference" (Konya 2020, p. 18). By contrast, the "Democracy Watches" gatherings were uniformly uniform: a single colour (red), and a single flag (the Turkish national standard) for all. Whereas the Gezi Park protests were bottom-up, encouraging a multitude of voices and emphasizing the need to learn from one another, the "Democracy Watch" gatherings were rigidly topdown, allowing only one voice, namely that of Erdoğan and his AKP. Indeed, the contrast between the two events is not just an analytic claim, it is emphasized by Erdoğan himself:

One of the biggest heroes of the July 15 was our youth ... Immediately taking action, they stood up against tanks and retrieved the areas invaded by the coup plotters ... Those coming there that night were not the youth of Gezi Park. Those who came there that night were the ones who loved the country.

(Presidency of the Republic of Turkey 2017)

Time and again during the "Democracy Watch" events, those present and those who opposed the plotters on the night of the coup are described as 
"the nation", while others are described either as "terrorists" or as "terrorist supporters". Moreover, the crowd participated actively in this construction, sharing their personal stories, booing when anyone was named as an enemy of the state (Acar and Reicher in progress). In this way Erdoğan, the AKP leadership and their followers co-created an exclusive boundary to Turkish nationhood.

Having said this, the prototypical "terrorist other" is identified with the Kurds and the pro-Kurdish political parties (notably the pro-Kurdish HDP, even though they held the third largest percentage of votes garnered by the four major parties). While other opposition parties such as the CHP were invited to participate in the Democracy Meeting (albeit on Erdoğan's terms), the HDP was not, and when asked why Erdoğan replied:

As I always say, I can meet any opinion, any group that has the four principles: One homeland, one nation, one state, one flag ... I do not come together with those who are involved in terrorism and are intertwined with terrorism. This is my red line.

(Diken 2016)

Just as what happened in Gezi Park did not stay in Gezi Park but impacted longer-term social relations, the same is true of the "Democracy Watch" gatherings - although this time they undermined rather than promoted processes of reconciliation. Prior to the coup, the government was involved in a peace process with the Partiya Karkerên Kurdistan (PKK - Kurdish Workers' Party). It was the calm brought about by this process in a region that had been marked by conflict for decades that allowed the HDP to gain popularity as a pro-minority and egalitarian party. The "Democracy Watch" gatherings were part of a process, however, which positioned Erdoğan's opponents as enemies of the state and, hence, as illegitimate participants in the political and social sphere.

This had begun pre-coup after the HDP won 80 seats in the June 2015 general election and deprived Erdoğan's AKP of an overall majority. Mounting conflict led to the collapse of the peace process with the PKK. As we have seen, the "Democracy Watch" gatherings were used to broaden the definition of the "terrorist other" to include the HDP. Subsequently, it was broadened still further to include all those who criticized Erdoğan's Kurdish policy, with many of the 1,128 intellectuals and academics, who, in January 2016, had signed a "peace petition", being prosecuted as "terrorist sympathizers". In effect, to oppose Erdoğan was to be a "non-citizen" (Acar and Coşkan 2020).

\section{Conclusion}

The two cases we have considered in this chapter highlight the different ways in which crowd events can impact upon how boundaries of identity are drawn and intergroup histories rewritten. 
In sum, the mass rallies of August 2016, like those witnessed three years earlier in Gezi Park, served as a performative construction of group boundaries - and, more specifically, of Turkish national identity. As acts of boundary making both necessarily involved inclusion and exclusion, unification and differentiation. But whereas the Gezi Park protests served to broaden the conventional boundaries of inclusion, the "Democracy Watch" gatherings served to narrow down previous definitions. Correspondingly, whereas the Gezi Park protests promoted reconciliation (including between nationalists and Kurds), the August 2016 rallies disrupted reconciliation with the Kurds and accentuated existing fault lines in society between Erdoğan's mainly traditional and rural base and his urban liberal opponents so as to produce new forms of conflict.

The overall point that comes out of this is that reconciliation may well be a matter of category relations but that, more basically, category relations are a function of how category boundaries are drawn - that is, how we define who is "us" and who is "them". And, as recent research has shown, crowd events are one of the major sites in which these definitions can change (Drury and Reicher 2020). That is not to say that crowds always produce such change. Indeed, many crowds serve to confirm existing social relations. Indeed, there is an abundance of literature on how commemorations, festivals and other mass phenomena are central to telling us who we are and who is "us" (e.g. Gillis 1994). But that doesn't mean that these are irrelevant for reconciliation, simply that they confirm rather than change existing prospects for reconciliation.

One final comment based on a final contrast between the Gezi Park protests and the "Democracy Watches" rallies: as we stressed earlier, the Gezi Park crowds were not intended as a reconciliation process, but they nevertheless led to a process of reconciliation. The "Democracy Watch" gatherings, however, were very deliberately choreographed in order to narrow Turkish nationhood around the figure of the president. Yet the effects came about irrespective of whether they were intended to or not. It is simply that, if we can understand the path from crowd dynamics to categorical change to the prospects for reconciliation, we are in a better position to harness those dynamics for the sake of resolving old antagonisms rather than creating new ones.

\section{References}

Acar, Yasemin Gülsüm. "Gezi'den Sonra Ne Oldu? Güçlenmenin, Politikleşmenin ve Örgütlenmenin Kolektif Eylemlerdeki Rolü [What happened after Gezi? The role of empowerment, politicization and organization in collective action]". Turkish Psychology Articles, vol. 21, 2018, pp. 62-81.

Acar, Yasemin Gülsüm, and Canan Coşkan. "Academic activism and its impact on individual-level mobilization, sources of learning, and the future of academia in Turkey”. Journal of Community \& Applied Social Psychology, vol. 30, no. 4, 2020, pp. 388-404, https://doi.org/10.1002/casp.2455. 
Acar, Yasemin Gülsüm, and Elif Sandal Önal. "Military coups in Turkey and their effect on political culture and national identity". Intergroup Relations in Turkey, Abingdon, Routledge and CRC Press, forthcoming.

Acar, Yasemin Gülsüm, and Stephen D. Reicher. How crowds stop social change: An analysis of pro-government democracy meetings in post-coup Turkey. Manuscript in preparation.

Acar, Yasemin Gülsüm, and Özden Melis Uluğ. "Examining prejudice reduction through solidarity and togetherness experiences among Gezi Park activists in Turkey". Journal of Social and Political Psychology, vol. 4, no. 1, 2016, pp. 166179, https://doi.org/10.5964/jspp.v4i1.547.

Anderson, Benedict. Imagined communities: Reflections on the origin and spread of nationalism. London, Verso, 1983.

Davis, Natalie Zemon. "The rites of violence: Religious riot in sixteenth-century France”. Past \& Present, vol. 59, no. 1, 1973, pp. 51-91, https://doi.org/10.1093/pa st/59.1.51.

Diken. "HDP'yi Yenikapı'ya çağırmayan Erdoğan: Terörle iç içe olanlarla bir araya gelmem". 7 August 2016, www.diken.com.tr/hdpyi-yenikapiya-da-davet-etmeye n-Erdoğan-terorle-ic-ice-olanlarla-bir-araya-gelmem/.

Drury, John, and Stephen D. Reicher. "Collective action and psychological change: The emergence of new social identities". British Journal of Social Psychology, vol. 39, no. 4, 2000, pp. 579-604, https://doi.org/10.1348/014466600164642.

Drury, John, and Stephen D. Reicher. "Collective psychological empowerment as a model of social change: Researching crowds and power". Journal of Social Issues, vol. 65, no. 4, 2009, pp. 707-725, https://doi.org/10.1111/j.1540-4560.2009.01622.x.

Drury, John, and Stephen D. Reicher. "Crowds and collective behaviour". Oxford research encyclopedia: Psychology. Oxford, Oxford University Press, 2020, doi:10.1093/acrefore/9780190236557.013.304.

Gelvin, James L. Divided loyalties: Nationalism and mass politics in Syria at the close of empire. Berkeley, University of California Press, 1998.

Gillis, John R. Commemorations: The politics of national identity. Princeton, NJ, Princeton University Press, 1994.

Gül, Murat, John Dee, and Cahide Nur Cünük. "İstanbul's Taksim Square and Gezi Park: The place of protest and the ideology of place". Journal of Architecture and Urbanism, vol. 38, no. 1, 2014, pp. 63-72, https://doi.org/10.3846/20297955.2014. 902185.

Hürriyet Daily News. "Erdoğan's remarks on treaty that formed modern Turkey irk opposition". 29 September 2016, www.hurriyetdailynews.com/Erdoğans-rema rks-on-treaty-that-formed-modern-turkey-irk-opposition-104386.

Konya, Nazlı. "Making a people: Turkey's 'Democracy Watches' and Gezi-envy". Political Theory, 2020, https://doi.org/10.1177/0090591720981904.

Le Bon, Gustave. The crowd: A study of the popular mind. 1895. Reprint. New York, Viking, 1960.

Neville, Fergus G., Novelli, John Drury, and Stephen D. Reicher. "Shared social identity transforms social relations in imaginary crowds". Group Processes \& Intergroup Relations, 2020, https://doi.org/10.1177\%2F1368430220936759.

Ozouf, Mona. Festivals and the French Revolution. Cambridge, MA, Harvard University Press, 1991.

Poulton, Hugh. The top hat, the grey wolf and the crescent. New York, New York University Press, 1997. 
Presidency of the Republic of Turkey. Our youth were on the front line against July 15 coup attempt. 28 May 2017,www.tccb.gov.tr/en/news/542/77389/our-youth-wer e-on-the-front-line-against-july-15-coup-attempt.

Reicher, Stephen D. “'The Battle of Westminster': Developing the social identity model of crowd behaviour in order to explain the initiation and development of collective conflict”. European Journal of Social Psychology, vol. 26, no. 1, 1996, pp. 115-134, https://doi.org/10.1002/(SICI)1099-0992(199601)26:1<115:AID-EJSP740>3.0.CO;2-Z.

Reicher, Stephen D. “'La beauté est dans la rue': Four reasons (or perhaps five) to study crowds". Group Processes \& Intergroup Relations, vol. 20, no. 5, 2017, pp. 593-605, https://doi.org/10.1177/1368430217712835.

Reicher, Stephen D. "The psychology of crowd dynamics". Blackwell handbook of social psychology: Group processes, edited by Michael A. Hogg and Scott Tindale, Oxford, Blackwell, 2001, pp. 182-208.

Reicher, Stephen D. "The St. Pauls' riot: An explanation of the limits of crowd action in terms of a social identity model". European Journal of Social Psychology, vol. 14, no. 1, 1984, pp. 1-21, https://doi.org/10.1002/ejsp.2420140102.

Stott, Clifford, and John Drury. "Crowds, context and identity: Dynamic categorization processes in the "poll tax riot"”. Human Relations, vol. 53, no. 2, 2000, pp. 247-273.

Thompson, Edward P. "The moral economy of the English crowd in the eighteenth century". Past \& Present, no. 50, 1971, pp. 76-136.

Tajfel, Henri, and John C. Turner. "The social identity theory of intergroup behaviour". Psychology of intergroup relations, Chicago, Hall Publishers, 1986.

Taş, Hakk1. "The 15 July abortive coup and post-truth politics in Turkey". Southeast European and Black Sea Studies, vol. 18, no. 1, 2018, pp. 1-19, https://doi.org/10. 1080/14683857.2018.1452374.

Uluğ, Özden Melis, and Yasemin Gülsüm Acar. "Names will never hurt us': A qualitative exploration of Çapulcu identity through the eyes of Gezi Park protesters". British Journal of Social Psychology, vol. 58, no. 3, 2019, pp. 714-729, https://doi. org/10.1111/bjso.12305.

Uluğ, Özden Melis, and Yasemin Gülsüm Acar. "We are more than alliances between groups': A social psychological perspective on the Gezi Park protesters and negotiating levels of identity". "Everywhere Taksim": Sowing the seeds for a new Turkey at Gezi. Amsterdam, Amsterdam University Press, 2015.

Uluğ, Özden Melis, and Yasemin Gülsüm Acar. "What happens after the protests? Understanding protest outcomes through multi-level social change". Peace and Conflict: Journal of Peace Psychology, vol. 24, no. 1, 2018, p. 44, https://doi.org/10. 1037/pac0000269. 


\title{
14 Collective resilience
}

\author{
Sandra Penić, John Drury and Zacharia Bady
}

A classic pitfall of transitional justice discourse and practice resides in creating a binary between active perpetrators and passive victims (Gready and Robins 2014; Shaw et al. 2010). Affected civilians are generally assumed to be powerless, helpless and subject to various forms of suffering, whereas the ways in which they socially organize to avoid or cope with violence are typically neglected. Accordingly, transitional justice measures are all too often limited to institutional mechanisms dominated by international elite networks of donors and professionals, who claim rights on behalf of the victims (Madlingozi 2010). The participation of affected civilians is usually limited: a small number of citizens are involved in transitional justice mechanisms through prescribed roles, such as witnesses and defendants. Consequently, those most affected by violations frequently have little or no opportunity to impact upon the goals of the transitional justice process or the nature of particular mechanisms (Gready and Robins 2014).

This account of civilians as passive victims, however, tends to overlook emergent forms of coordination, solidarity and collective agency within survivor communities and, consequently, the role they could play in a process of conflict transformation. A growing number of studies suggest that collective violence does not necessarily disrupt communities and that collective coping with the adversity of war may be much more common than traditionally assumed. For example, a recent meta-analysis (Bauer et al. 2016) of nearly 20 studies conducted in over 40 countries has found a strong, persistent pattern that exposure to war violence tends to increase social cooperation at the local level, including community participation and prosocial behaviour (for similar findings see also Arjona et al. 2016; Bellows and Miguel 2009; Fritz 1961/ 1996; Gáfaro et al. 2014; Gilligan et al. 2014; Nussio 2019; Vélez et al. 2016). Why this occurs, however, is still poorly understood.

In sum, this chapter makes the argument that the capacity for collective resilience of civilians in armed conflicts represents an important forgotten resource for conflict transformation. We suggest that a better understanding of the processes through which communities cooperate to face war, and its aftermath, will also open new ways of thinking about conflict transformation, and that concepts developed in recent social psychological research on

DOI: $10.4324 / 9781003167280-18$ 
collective emergencies and disasters can inform our understanding of both types of processes.

\section{A social identity model of collective psychosocial resilience}

The overemphasis on passive victimhood and mental disorder as an outcome of conflict appears to echo a long tradition of thinking about collective behaviour in mass emergencies and disasters. Early theories of "panic" suggested that emergencies inevitably lead to psychological vulnerability and a breakdown of norms, with the crowd as the conduit for these pathological outcomes (see Quarantelli 2001). Yet one of the most frequently observed patterns of behaviour in emergencies and disasters is the very opposite of what "panic" theories would predict. The evidence of widespread supportive behaviours across a variety of types of emergency and disaster (e.g. Fritz and Williams 1957; Drury 2018; Grimm et al. 2014) contradicts the notion that individualistic flight and mindless contagion represent the default reactions, as "panic" theories suggest.

Existing social bonds - whether family ties or wider social capital networks - account for much of the evidence of supportive behaviours in emergencies and disasters (e.g. Aldrich and Meyer 2015; Feinberg and Johnson 2001; Mawson 2017). However, in many major incidents, there is evidence of widespread helping, cooperation and other forms of social coordination even among people with no prior connections (Clarke 2002). "Disaster community" and similar terms have been coined to characterize the emergent collective relationships of support and spontaneous cooperation commonly found immediately following an emergency (Kaniasty and Norris 1999).

The social identity model of collective psychosocial resilience (Drury 2012; Drury et al. 2019) attempts to explain this evidence of spontaneous social support and coordination among strangers in emergencies. It suggests that the sense of common fate people may experience in relation to a fire, bombing or other threat can lead them to see themselves as a single group. In gestalt terms, the figure-and-ground shifts from "me in relation to other individuals" to "us in relation to the emergency". Such common fate created by the disaster setting forms the basis of an emergent social identity, shared with others in the same situation.

Extending the boundaries of identity from the personal self to a collective self (which might be defined as "those of us affected by the emergency") means extending the boundaries of concern. Shared social identity motivates solidarity behaviours towards "us" in the form of support and cooperation. While the proposition that shared identity increases supportive behaviours towards ingroup members is well established (e.g. Gaertner and Dovidio 2012; Levine et al. 2005), the model described here applies this notion to events where there is time pressure and threat to both helper and helped. It also suggests that the shared social identity in question is one specific to, and 
a function of, that threatening context. Evidence that shared social identity arises in emergencies and increases supportive behaviours to others affected by the emergency is provided, for example, in interviews and archival analysis of a range of emergencies and disasters, including the 7 July 2005 London bombings, the 1989 Hillsborough disaster, sinking ships, floods and earthquakes (Drury et al. 2009a, 2009b; Ntontis et al. 2018).

In addition to providing the motivation to support others in the group, shared social identity can lead people to expect support from others who share their group membership. Expecting support, in such contexts, has a number of consequences. First, it increases people's sense of efficacy or empowerment. Second, it facilitates joint action, as people are able to anticipate and to coordinate each other's actions. Third, it enables people to regulate each other's behaviour and to ensure the collective response is in line with common norms and values. These different pathways, and how they produce coordinated support activities (such as, for example, the collective self-regulation of looters), have been documented empirically in a survey conducted among a representative sample of over 1,000 people who survived the Maule earthquake in Chile in 2010 (Drury et al. 2016).

Expected support, and the actions that flow from that support, make it easier for crowd members to help each other to reach safety, and hence contribute to their well-being and survival. Thus, collective psychosocial resilience, in this context, refers to "the way a shared identity allows groups of survivors to express and expect solidarity and cohesion, and thereby to coordinate and draw upon collective sources of support" (Drury et al. 2019).

Most "disaster communities" decline over time. Those affected exhaust their material and psychosocial resources, and previous social divisions resurface (Kaniasty 2020; Kaniasty and Norris 1999). Floods are a good example, here. In these events, the secondary stressors (Lock et al. 2012) following the disaster may cause more distress than the disaster itself, as people try to cope with insurance, continued disruption and damage to their homes. As a consequence, the need for psychosocial support through shared social identity can peak just at a time when the contextual affordances that produced such an identity - that is, the common fate experienced during the flood itself - may be diminished.

Recent research has investigated the processes by which the benefits of emergent shared identity may be retained in the "recovery" phase of a flood. Interviews carried out some months after the floods in York, UK, in 2015-16 suggested that those affected used a range of criteria to define themselves as a group (e.g. not just common fate in relation to the flood but also shared experience of secondary stressors afterwards). They also actively posited a group identity in various ways to keep the new community alive. This included referring to a shared history in conversation as a reminder of the common past, as well as organizing meetings, Facebook groups and commemorations in which a version of the shared identity of the flood community was invoked and celebrated (Ntontis et al. 2020). 
Some would argue that people affected by disaster eventually need to move on from the identities associated with the disaster and that, therefore, part of the recovery process is to let go of such identities rather than keep them alive. However, an important distinction should made between different types of identities associated with disasters. If a "victim" identity in which "others can never understand our needs" prevails, the possibility of forming supportive relationships with external groups may become closed off. But survivors also develop "resilient" collective identities, which are defined broadly enough to enable the mobilization of external solidarity. As an example, the support groups associated with the Grenfell Tower fire of 2017 have successfully created alliances with others to help survivors, families and the local community to campaign for justice (Tekin and Drury 2020).

\section{Collective psychosocial resilience in the context of political violence}

Because war and other forms of political violence can be so destructive, most research and practice related to transitional justice has been guided by a focus on the negative psychological and social impact of trauma (Vollhardt 2012). But a growing number of studies suggest that exposure to collective violence does not automatically have a debilitating effect, and that individuals and communities can be remarkably resilient. For example, several studies suggest that most people directly affected by traumatic events do not develop psychiatric disorders (Barber and Doty 2013; Linley and Joseph 2004) or that exposure to collective violence can increase social cooperation, prosocial behaviour, egalitarian preferences, community cohesion and participation (Bauer et al. 2016; Blattman 2009).

But how does this happen? As pointed by Bauer and colleagues (2016, p. 22), "the research to date has done a far better job of establishing the effect of war violence on later cooperation than of explaining it". Most available explanations tend to focus on social processes related to conflict dynamics. Some authors argue that experiencing violence collectively increases cohesion by reinforcing the conflict-defined identities (Lupu and Peisakhin 2017; Rohner et al. 2013). Similarly, some authors draw on evolutionary theories of parochial altruism to argue that intergroup competition - and collective violence as its extreme form - favours prosociality towards ingroup members (Choi and Bowles 2007; Haidt 2012). Other explanations focus on more local, community dynamics and point to a "collective coping mechanism whereby members of communities that have few options to flee band together to cope with threats and trauma" (Gilligan et al. 2014, p. 616, emphasis added).

A more comprehensive explanation can be drawn from the social identity model of collective psychosocial resilience exposed above (Drury 2012, 2018): the experience of common fate (shared exposure to collective violence) can foster shared social identity, which then serves as a basis for mutually supportive behaviour and coordinated action. Contrary to previous 
explanations, the model does not presume that violence necessarily reinforces already established or conflict-defined identities; violence can also be conducive to the emergence of new social identities - a new "we" - and sometimes even of inclusive social identities beyond the conflict cleavage. Prima facie, wars differ from disasters in important ways. Yet, in many disasters, there is a clear intergroup context of historical disadvantage (Tekin and Drury submitted) or outright intergroup hostility (Drury et al. 2009). These contexts shape attributions of cause and blame, and they impact relations within the affected ingroup, where social divisions can be exacerbated as well as transcended (Kaniasty and Norris 1999). For these reasons, we suggest that the social identity model carries over from disasters to wars: it can help us to explain the conditions under which collective resilience arises in both types of calamities.

\section{Political violence and the reinforcement of shared social identity}

A number of studies have shown that experiencing collective violence can reinforce existing social identities that facilitate prosocial behaviour and coordinated action among ingroup members. For example, in the wellresearched aftermath of the " $9 / 11$ " terrorist attack on the World Trade Center, there was a strong increase in national patriotism (Skitka 2005) and the consequent supportive behaviours, such as increased volunteering and donating (Glynn et al. 2003; Penner et al. 2005). Robert Putnam, a long-time critic of an increasingly individualistic and atomistic society in the United States, has observed in an article entitled "A better society in a time of war":

Since Sept. 11, we Americans have surprised ourselves in our solidarity. Roughly a quarter of all Americans, and more than a third of all New Yorkers, report giving blood in the aftermath of the attacks. Financial donations for the victims and their rescuers have reached almost $\$ 1$ billion. Attendance at places of worship has increased.

New York Times (2001)

The strengthening of shared social identities is also well documented in cases of internal intergroup conflicts, such as civil wars. Studies focusing on the communal level have shown that collective exposure to violence can reinforce social cohesion and solidarity (Bauer et al. 2016). In contrast to the assumption that civilians are passive victims of violence, which predominates in transitional justice discourse, recent studies suggest that organized communities can be successful even in avoiding or limiting violence. Oliver Kaplan (2017) explored cases from Colombia to show how unarmed civilians can influence armed actors and limit violence. His research highlights the role of social identity processes, particularly the role of community cohesion in reinforcing peaceful community norms and enabling collective organizing. 
However, not all studies show that violence reinforces the established social identities; sometimes it has a detrimental impact on community or national cohesion (e.g. Hager et al. 2019; Kijewski and Freitag 2018; Barclay Child and Nikolova 2020; Dell and Querubin 2018; Vélez et al. 2016). According to the social identity model of collective psychosocial resilience (Drury 2012; Drury et al. 2019), the emergence of shared social identity is predicated on the sense of common fate in relation to collective violence. In conflict dynamics, violence that is indiscriminately imposed on an entire community by an outgroup is particularly likely to reinforce the sense that "we are all in this together" and consequently solidify the shared identity (Drury and Reicher 2009). For example, in the cases of violent political repression in Tunisia and Egypt, Elizabeth Nugent (2020) showed how indiscriminate repression by the authoritarian regime created shared political identity, decreased polarization and increased cooperation among the members of opposition; by contrast, targeted repression fragmented the opposition and contributed to its failure to challenge authoritarian regimes. Krzysztof Krakowski (2020) found that, in Colombia, indiscriminate violence against local communities increased community cohesion by spurring individuals to band together, strengthening their shared communal identity. However, asymmetric guerrilla war characterized by selective violence against civilians reduced community cohesion by instilling fear and suspicion among community members. Fear of one's neighbours can contribute to the establishment of a "law of silence" that erodes social bonds and decreases community cohesion (see Kaplan 2017).

\section{Political violence and the foregrounding of inclusive identities}

The reinforcement of conflict-induced identities and internal cohesion due to violence can at the same time enhance the cleavages between the conflict groups. Guided by the assumption that "violence begets violence", some authors have argued that the conflict-induced reinforcement of intragroup bonding and cooperation comes at the cost of further outgroup derogation (Choi and Bowles 2007; Haidt 2012). For example, whereas studies on the 9/ 11 terrorist attack have shown, as previously described, an increase in national patriotism and prosocial behaviour towards compatriots, they have also shown that the violence fostered mobilization for the invasion of Iraq and widespread Islamophobia (Ross 2013). The troubling corollary is, therefore, that collective violence might enhance intragroup cooperation while simultaneously raising the risk of future social divisions and renewed intergroup conflict (Bauer et al. 2016).

However, a growing number of studies indicate that collective victimization does not necessarily lead to outgroup antagonism but can, on the contrary, foster prosocial behaviour beyond group boundaries. Studies in various conflict-affected societies, such as Liberia (Hartman and Morse 2020), Darfur (Hazlett 2020), Colombia (Tellez 2019), the North Caucasus (Bakke et al. 
2009), the former Yugoslavia (Penic et al. 2017, 2018, 2020; Spini et al. 2019), as well as comparative studies conducted across multiple countries (Elcheroth 2006; Spini et al. 2008) show that collective exposure to violence can enhance support for peace, human rights or reconciliation with the "enemy" side. Some authors explain such findings in terms of individual psychological factors, such as the "post-traumatic growth" of war-affected individuals, who become more altruistic and socially engaged (see Bellows and Miguel 2009; Gilligan, Pasquale and Samii 2014), or by heightened awareness of the actual cost of war, which makes peace and reconciliation a more palatable option for directly affected individuals (see Bakke et al. 2009; Fair et al. 2018; Tellez 2019).

We suggest that the findings can be further explained by the social identity model of collective psychosocial resilience (Drury 2012; Drury et al. 2019): when violence is collectively understood as shared across the conflict cleavage, it can foster the preservation or emergence of inclusive social identities, which are the basis for pro-peace behaviour. For example, studies show that inclusive social identities are at the core of rescue and solidarity behaviour in genocides (Monroe 2008; Reicher et al. 2006) and that inclusive identities among victims of violence enhance their support for reconciliation (see Chapter 12 in this volume). Inclusive identities may be new (e.g. inclusive victim groups) or rooted in existing social categories (e.g. inclusive local or national identities).

Particularly telling is a study on the emergence of an inclusive identity and resistance to violence in a context in which it would have been least expected: the trench warfare in the First World War. With strongly bonded "brothers in arms" in a persistent, violent and bloody conflict against the enemy guided by the official "kill or be killed" policy, trench warfare seemingly epitomizes the inherent link between intragroup cooperation and intergroup aggression. Yet Tony Ashworth (2000) showed systematic occurrences of "live and let live" truces, whereby enemies stopped fighting by agreement for a period of time, the best-known example being the Christmas truces in 1914. These truces occurred despite being explicitly forbidden by authority and, hence, were unofficial and illegal. The process of the emergence of truces described by Ashworth largely corresponds to the social identity model of collective psychosocial resilience. Ashworth describes how the conditions of close proximity and the shared experience of war eroded abstract images of the enemy and fostered perception of similarities and common fate. This led to the emergence of "a consciousness of kind among antagonists" (p. 133) and "fellow-feelings" (p. 143), further strengthened through shared conversations, humour, reciprocal singing and intertrench gossip. The emergence of the perception of common fate and shared identity among trench soldiers was facilitated by the structural similarities in conditions on both sides, as powerfully voiced by one soldier:

When one is in the front line one cannot help having a fairly deep sympathy for the wretched fellow in the other front line across 'no-man's- 
land'; one knows that he is going through just as many dangers and discomforts, and that he is simply carrying out the orders of some general whose dangers and discomforts are infinitely less, and the hatred that you both have towards these generals breeds a common sympathy that is irresistible.

A growing number of studies further emphasize the importance of structural characteristics of violence - in particular, the degree to which victimization is shared across group boundaries - for the emergence of inclusive identities. These studies show that collective exposure to symmetric violence, which similarly affects members of opposing groups, can give rise to a perception of commonality of fate and shared grievances that challenge the "us versus them" framing of the conflict. By contrast, asymmetric violence, which disproportionately affects one of the groups, tends to freeze group boundaries, leave an enduring sense of the impossibility of togetherness and, thereby, fuel intergroup animosities further (Penic et al. 2017, 2018; Spini 2008; Spini, Morselli and Elcheroth 2019).

Other studies highlight the role of leaders and other influence agents in the mobilization of inclusive identities (Haslam et al. 2010). Jana Krause (2018) conducted a thick ethnographic analysis of two vulnerable communities - i.e. religiously mixed and socially excluded - that managed to prevent violence between religious groups in Nigeria and Indonesia. She showed that the key social process involved the active mobilization of inclusive identities across the conflict cleavage by local community leaders. This included the rejection of simplistic conflict narratives and one-sided blame, and the promotion of proactive "we-thinking" and inclusive local community identities (e.g. "us people of Dadin Kowa" as opposed to Muslim versus Christian identities). The inclusive community identity was a basis for the emergence of collective agency and social control, such as the establishment of informal institutions for conflict management, and the emergence of norms of repression of radical individuals who wanted to instigate fighting.

As these various studies show, violence does not necessarily beget violence, but it can foster support for peace and reconciliation. Within the scope of the Pluralistic Memories Project, researchers from Burundi, Sri Lanka and Palestine have collected some 200 testimonies among witnesses of collective violence. The testimonies show that stories about identity-based victimization tend to co-exist with stories that challenge the conflict-defined boundaries and the simple representation of "us versus them", for example the experiences of help and support across frontlines in the midst of violence. Analyses of nationally representative surveys conducted in Sri Lanka or in the West Bank and Jerusalem show that such diverse conflict narratives are an important resource for conflict transformation: being able to know and freely communicate about diverse experiences that go beyond the simple "us versus them" narrative is linked to increased community attachment and perceived 
efficacy (Penic and Elcheroth 2020), and to stronger support for the establishment of transitional justice mechanisms, such as truth commissions, impartial prosecutions or reparations (Penic et al. submitted).

Yet despite existing as valuable resources in the stock of lived experiences, stories of inclusive resilience tend to remain invisible in public discourse. For what reason? We have seen that leadership matters in mobilizing inclusive identities, and the same observation applies to the mobilization of exclusive, antagonistic identities (Haslam et al. 2010). Intergroup conflicts thus typically involve an interpretative struggle over the delineation of the boundaries of common fate (Elcheroth and Reicher 2014; Herrera and Reicher 1998). As part of this struggle, influence agents may selectively promote or suppress stories of conflict experiences to give credence to their preferred narrative. Stories of solidarity across "enemy" lines, in particular, tend to be omitted by influential warmongering actors who emphasize more readily stories of ingroup victimization (e.g. Ramanathapillai 2006). And such motivated omissions are not limited to discourses of political and military leaders. In the case of the 1914 Christmas truce, for instance, newspapers in belligerent countries either minimized the extent of fraternization or - in the case of France - even censored the stories entirely (Weintraub 2001). In times of war, even in contemporary democracies, the mainstream media channels typically construct conflict-supportive narratives, about ingroup victimization and outgroup perpetration, while marginalizing or omitting contradictory information (Bar-Tal et al. 2014; Feldman et al. 2015; Happer and Philo 2013; Lewis 2004). Such politicized narratives are the main source of information about the conflict for many people living far from the front lines. Ironically, then, studies show that the greater the distance from the front lines, the lower the support for peace (Tellez 2019), transitional justice principles (Elcheroth and Spini 2014) or reconciliation (Bakke et al. 2009).

\section{Political violence and the emergence of new identities}

While collective violence can foster a sense of common fate along the boundaries of already existing, psychologically meaningful groups (e.g. one's nation or local community), it can - through the same socio-psychological mechanism - produce new forms of social categories and actors, such as emergent survivor communities, for example (Drury and Reicher 2000; Drury, Cocking and Reicher 2009a, 2009b ).

The power of events of collective violence to shape social identities has been shown by Bady (2020), who examined how war experiences related to social identities among a representative sample of the Sri Lankan population eight years after the end of the civil war that tore the country for almost 30 years. Participants were asked to evaluate how 12 potential markers of identity (e.g. religion, language, economic situation) mattered to them and others in various ways, as a basis for social identification, social support, discrimination or perceived social norms, for example. Bady's analysis not only 


\section{6}

Sandra Penić, John Drury and Zacharia Bady

showed that participants' understanding of identity depended on the area's cumulative exposure to violence, but that it was shaped by specific historic war events. These findings suggest that localized experiences of war have sparked the emergence of shared conceptions of identity that remain tied to the triggering event over years (in one case, the impact was still discernible two and a half decades later).

To understand such longevity of identities that have arisen in specific circumstances, it is important to consider that subsequent (post-)war experiences may be as important as the triggering event itself in drawing the boundaries of common fate. Research among Syrian refugees in Jordan showed that the longer refugees had been in exile, the more secondary stressors (e.g. being unemployed) predicted identification with other refugees through a sense of common fate (Alfadhli et al. 2019: 5-11). In line with the social identity model of collective psychosocial resilience (Drury 2012; Drury et al. 2019), identification with other refugees predicted providing as well as expecting support from other refugees, the latter in turn predicting a sense of collective efficacy (among Syrian refugees in both Turkey and Jordan; Alfadhli et al. 2019).

Ethnographic observations and interviews with Syrian refugees in Jordan further show that external actors and institutions create the context that defines which shared identity is relevant and which forms of resilience are possible. In order to access basic humanitarian aid, institutional mechanisms categorize and treat refugees as a group, and hence help to define the boundaries of mutual support by reinforcing a sense of shared identity among them (Alfadhli and Drury 2018). The refugee identity is also a basis of stigma and discrimination from the locals, which further reinforces a sense of common fate and identity (Alfadhli and Drury 2018).

The so-called Northern Muslims in Sri Lanka constitute another instructive case discussed in detail by Surenthiraraj (2020; see also Chapter 6 in this volume). It illustrates how a resilient community can emerge out of a war experience, but also shows that the "victim" image entailed in transitional justice and humanitarian mechanisms can, ironically, constrain possibilities of resilience. In the midst of a civil war raging between the Liberation Tigers of Tamil Ealam (LTTE) and the Sri Lankan armed forces, the LTTE forcibly evicted the entire Muslim population from the five Northern Province districts of the island under its control. The expelled relocated mostly among Muslim communities in other parts of the country, guided by expectations of solidarity based on shared Muslim identity (Brun 2010; Surenthiraraj and de Mel 2019). And, indeed, testimonies from the displaced typically emphasize how host communities initially assisted them in many ways, such as offering them shelter in their homes, land and schools, and providing them with food and clothes (Brun 2010; Citizens' Commission 2012; Surenthiraraj and de Mel 2019). The label "Northern Muslim" gradually came to denote the new community created by the common experience of expulsion, both for the evicted themselves and for other Sri Lankans (Thiranagama 2011, 2013). 
As the displacement - first believed to be temporary - persisted, a number of circumstances fostered tensions between guest and host communities. As the Northern Muslims proved resilient in terms of educational and economic advancement as well as in terms of political activism, some members of the host communities came to perceive them as threatening competitors for limited resources who benefited from unfair advantages due to their displaced status (Brun 2010; Citizens' Commission 2012; Haniffa 2015). When return became possible with the ending of the war, state and humanitarian agencies considered that assistance for the Northern Muslims should have a low priority compared to that for those displaced during the last stages of the war. This illustrates an ironic consequence of humanitarian and transitional justice discourse that evaluates victimhood in terms of "the greatest need" (Haniffa 2015): their very resilience in facing the challenges of displacement eventually complicated the implementation of the Northern Muslims' rights as well as their relations with the host communities where they have lived in displacement. As a result, three decades after their eviction, many Northern Muslims have to prove their resilience once more in managing life between two places.

As the case of the Northern Muslims shows, the resilience of war-affected communities should not imply negating the responsibility of their state, or of the international community, to protect and support them. The discourse of "resilience" has sometimes been used as a cover by those in power to avoid their responsibility of looking after the most vulnerable. For example, Juliet Gardiner (2010) explains how the British government used the slogan "Britain can take it" as a propaganda tool when many people in London were being killed and suffered during the Blitz air raids of the Second World War. Civilians' capacity to prevent and cope with collective violence cannot replace adequate external protection, but should rather be acknowledged as a crucial first step in planning protection and prevention. Models of resilience need to specify and be explicit that the "strengths" of survivor groups and others, in the long term, often depend on the role of the authorities in scaffolding their agency - through provision of appropriate information and resources (Drury et al. 2019).

\section{Conclusion}

In this chapter, we have reviewed multiple studies from various conflictaffected societies that empirically show that civilians in armed conflicts are not just passive victims, but can be remarkably resilient. These studies point to the social and collective nature of resilience: whereas individuals may have limited capacity to face collective violence alone, when they band together they can develop social resources to jointly cope with hardship but also to confront the divisive logic of violence itself. We have applied the social identity model of collective psychosocial resilience to explain this process: under certain circumstances, collective violence can foster a sense of common fate 


\section{8}

Sandra Penić, John Drury and Zacharia Bady

and the emergence of shared social identity, which then serves as a basis for solidarity and collective agency. Going beyond the predominant focus on the conflict-defined identities in research on intergroup conflicts, the studies we have reviewed show that violence can reinforce various existing social identities (e.g. local community identity), but also foster the emergence of new social identities, and sometimes even inclusive identities beyond the conflict cleavage.

Whereas collective resilience seems to be ubiquitous in conflict settings, it remains a forgotten resource for conflict transformation in transitional justice discourse and practice, which tend to focus on the victimhood of affected civilians. Yet there are concrete dangers of such misplaced focus. Whenever transitional justice silences experiences of collective resilience, it is at risk of feeding into history-writing that depicts communities as helpless, disoriented or otherwise dependent on their state or on the international community to guide, contain and protect them. This can be actively disempowering for the affected communities, leaving them with little or no agency in challenging power relations. Moreover, the focus on victimhood as a dominant form of identity politics in post-conflict settings can foster a climate of competitive victimhood claims that deny victim status to the "other", thereby perpetuating conflict-defined divisions. It follows that when transitional justice practice makes visible how communities have built social resources to jointly cope with hardship or confront the divisive logic of violence, it conveys inspiring experiences of collective empowerment. However, the recognition of community resilience does not absolve the state or international actors from the responsibility of providing adequate civilian protection. Instead, it should be a starting point for designing effective protection together with the directly concerned communities, drawing upon their experiences and capacities.

For example, stories of collective resilience can be an important source for social learning that can empower communities when faced with future risks of violence. Moreover, stories about communities that have stood together against the divisions can serve as symbols of hope, demonstrating that living together and jointly working for reconciliation are valuable and realistic objectives shared across conflict lines (see Krause 2018). The widespread dissemination of such stories through transitional justice practice could strengthen cooperative norms and the legitimacy of pro-peace leadership, which are vital for the establishment of sustainable peace.

\section{References}

Aldrich, Daniel P., and Michelle A. Meyer. "Social capital and community resilience". American Behavioral Scientist, vol. 59, no. 2, 2015, pp. 254-269, doi:10.1177/0002764214550299.

Alfadhli, Khalifah, H. Cakal, and J. Drury. "The role of emergent shared identity in psychosocial support among refugees of conflict in developing countries". International Review of Social Psychology, vol. 32, no. 1, 2019, p. 2. 
Alfadhli, Khalifah, and John Drury. "The role of shared social identity in mutual support among refugees of conflict: An ethnographic study of Syrian refugees in Jordan”. Journal of Community \& Applied Social Psychology, vol. 28, no. 3, 2018, pp. $142-155$.

Arjona, Ana. "Institutions, civilian resistance, and wartime social order: A processdriven natural experiment in the Colombian Civil War". Latin American Politics and Society, vol. 58, no. 3, 2016, pp. 99-122.

Ashworth, Tony. Trench warfare, 1914-1918: The live and let live system. London, Palgrave Macmillan, 2000.

Bady, Zacharia. Ethnicity and complex identities in times of uncertainty: A configurational approach to study multiple self-positionings and their perceived recognition by others in social surveys. Unpublished doctoral dissertation, University of Lausanne, 2020.

Bakke, Kristin M., John O’Loughlin, and Michael D. Ward. "Reconciliation in conflict-affected societies: Multilevel modelling of individual and contextual factors in the North Caucasus of Russia". Annals of the Association of American Geographers, vol. 99, no. 5, 2009, pp. 1012-1021.

Barber, Brian K., and Samuel Benjamin Doty. "How can a majority be resilient? Critiquing the utility of the construct of resilience through a focus on youth in contexts of political conflict". Handbook of resilience in children of war, edited by Chandi Fernando and Michel Ferrari, New York, Springer, 2013, pp. 233-252.

Barclay Child, Travers, and Elena Nikolova. "War and social attitudes". Conflict Management and Peace Science, vol. 37, no. 2, 2020, pp. 152-171.

Bar-Tal, Daniel, Neta Oren, and Rafi Nets-Zehngut. "Sociopsychological analysis of conflict-supporting narratives: A general framework". Journal of Peace Research, vol. 51, no. 5, 2014, pp. 662-675.

Bauer, Michal, Christopher Blattman, Julie Chytilová, Joseph Henrich, Edward Miguel, and Tamar Mitts. "Can war foster cooperation?". Journal of Economic Perspectives, vol. 30, no. 3, 2016, pp. 249-274.

Bellows, John, and Edward Miguel. "War and local collective action in Sierra Leone". Journal of Public Economics, vol. 93, nos 11-12, 2009, pp. 1144-1157.

Blattman, Christopher. "From violence to voting: War and political participation in Uganda". American Political Science Review, vol. 103, no. 2, 2009, pp. 231-247.

Brun, Cathrine. "Hospitality: Becoming 'IDPs' and 'hosts' in protracted displacement". Journal of Refugee Studies, vol. 23, no. 3, 2010, pp. 337-355.

Brun, Cathrine. "Local citizens or internally displaced persons? Dilemmas of long term displacement in Sri Lanka". Journal of Refugee Studies, vol. 16, no. 4, 2003, pp. 376-397.

Choi, Jung-Kyoo, and Samuel Bowles. "The coevolution of parochial altruism and war”. Science, vol. 318, no. 5850, 2007, pp. 636-640.

Citizen's Commission on the Expulsion of Muslims from the Northern Province by the LTTE in October 1990. The quest for redemption: The story of the Northern Muslims. Colombo, Law \& Society Trust, 2012.

Clarke, Lee. "Panic: Myth or reality?". Contexts, vol. 1, no. 3, 2002, pp. 21-26.

Dell, Melissa, and Pablo Querubin. "Nation building through foreign intervention: Evidence from discontinuities in military strategies". The Quarterly Journal of Economics, vol. 133, no. 2, 2018, pp. 701-764.

Drury, John "Collective resilience in mass emergencies and disasters: A social identity model”. The social cure: Identity, health, and well-being, edited by Jolanda Jetten, 
Catherine Haslam and S. Haslam Alexander, Hove, Psychology Press, 2012, pp. 195-215.

Drury, John. "The role of social identity processes in mass emergency behaviour: An integrative review". European Review of Social Psychology, vol. 29, no. 1, 2018, pp. 38-81, https://doi.org/10.1080/10463283.2018.1471948.

Drury, John, Rupert Brown, Roberto González, and Daniel Miranda. "Emergent social identity and observing social support predict social support provided by survivors in a disaster: Solidarity in the 2010 Chile earthquake". European Journal of Social Psychology, vol. 46, no. 2, 2016, pp. 209-223.

Drury, John, Holly Carter, Chris Cocking, Evangelos Ntontis, Selin Tekin Guven, and Richard Amlôt. "Facilitating collective resilience in the public in emergencies: Twelve recommendations based on the social identity approach". Frontiers in public health, vol. 7, 2019, pp. 141.doi:10.3389/fpubh.2019.00141.

Drury, John, Chris Cocking, and Steve Reicher. "Everyone for themselves? A comparative study of crowd solidarity among emergency survivors." British Journal of Social Psychology, vol. 48, no. 3, 2009a, pp. 487-506, doi:10.1348/014466608X357893.

Drury, John, Chris Cocking, and Steve Reicher. "The nature of collective resilience: Survivor reactions to the 2005 London bombings". International Journal of Mass Emergencies and Disasters, vol. 27, no. 1, 2009b, pp. 66-95.

Drury, John, and Steve Reicher. "Collective action and psychological change: The emergence of new social identities". British Journal of Social Psychology, vol. 39, no. 4, 2000, pp. 579-604.

Drury, John, and Steve Reicher. "Collective psychological empowerment as a model of social change: Researching crowds and power". Journal of Social Issues, vol. 65, no. 4, 2009, pp. 707-725.

Elcheroth, Guy. "Individual-level and community-level effects of war trauma on social representations related to humanitarian law". European Journal of Social Psychology, vol. 36, no. 6, 2006, pp. 907-930.

Elcheroth, Guy, and Stephen D. Reicher. "Not our war, not our country": Contents and contexts of Scottish political rhetoric and popular understandings during the invasion of Iraq". British Journal of Social Psychology, vol. 53, no. 1, 2014, pp. $112-133$.

Elcheroth, Guy, and Dario Spini. "Beyond collective denial: Public reactions to human rights violations and the struggle over the moral continuity of communities". War, community, and social change, edited by Guy Elcheroth, Dario Spini and Dinka Corkalo Biruski, New York, Springer, 2014, pp. 205-226.

Fair, C. Christine, Rebecca Littman, Neil Malhotra, and Jacob N. Shapiro. "Relative poverty, perceived violence, and support for militant politics: Evidence from Pakistan". Political Science Research and Methods, vol. 6, no. 1, 2018, pp. 57-81.

Feinberg, William E., and Norris R. Johnson. "Primary group size and fatality risk in a fire disaster". Human behavior in fire: Understanding human behavior for better fire safety design. Cambridge, MA, Second International Symposium, 2001, pp. 11-22.

Feldman, Stanley, Leonie Huddy, and George E. Marcus. Going to war in Iraq: When citizens and the press matter. Chicago, University of Chicago Press, 2015.

Fritz, Charles E. Disasters and mental health: Therapeutic principles drawn from disaster studies. Newark, Disaster Research Center, University of Delaware, 1961/1996.

Fritz, Charles E., and Harry B. Williams. "The human being in disasters: A research perspective". The Annals of the American Academy of Political and Social Science, vol. 309, no. 1, 1957, pp. 42-51, doi.org/10.1177/000271625730900107. 
Gaertner, Samuel L. and John F. Dovidio. "The common ingroup identity model". Handbook of theories of social psychology, vol. 2, edited by Paul A. M. Van Lange, Arie W. Kruglanski and E. Tory Higgins, Thousand Oaks, CA, SAGE, 2012, pp. 439-457.

Gáfaro, Margarita, Ana María Ibáñez, and Patricia Justino. Local institutions and armed group presence in Colombia. HiCN Working Paper 178. Households in Conflict Network, Brighton, University of Sussex, Institute of Development Studies, 2014.

Gardiner, Juliet. The Blitz: The British under attack. London, HarperCollins, 2010.

Gilligan, Michael J., Benjamin J. Pasquale, and Cyrus Samii. "Civil war and social cohesion: Lab-in-the-field evidence from Nepal". American Journal of Political Science, vol. 58, no. 3, 2014, pp. 604-619.

Glynn, Simone A., Michael P. Busch, George B. Schreiber, Edward L. Murphy, David J. Wright, Yongling Tu, and Steven H. Kleinman. "Effect of a national disaster on blood supply and safety: The September 11 experience". Jama, vol. 289, no. 17, 2003, pp. 2246-2253.

Gready, Paul, and Simon Robins. "From transitional to transformative justice: A new agenda for practice”. International Journal of Transitional Justice, vol. 8, no. 3, 2014, pp. 339-361.

Grimm, Anna, Lynn Hulse, Marek Preiss, and Silke Schmidt. "Behavioural, emotional, and cognitive responses in European disasters: Results of survivor interviews". Disasters, vol. 38, no. 1, 2014, pp. 62-83.

Hager, Anselm, Krzysztof Krakowski, and Max Schaub. "Ethnic riots and prosocial behavior: Evidence from Kyrgyzstan”. American Political Science Review, vol. 113, no. 4, 2019, pp. 1029-1044.

Haidt, Jonathan. The righteous mind: Why good people are divided by politics and religion. New York, Vintage, 2012.

Haniffa, Farzana. "Competing for victim status: Northern Muslims and the ironies of Sri Lanka's post-war transition". Stability: International Journal of Security and Development, vol. 4, no. 1, 2015, p. 21, https://doi.org/10.5334/sta.fj.

Happer, Catherine, and Greg Philo. "The role of the media in the construction of public belief and social change". Journal of Social and Political Psychology, vol. 1, no. 1, 2013, pp. 321-336.

Hartman, Alexandra C., and Benjamin S. Morse. "Violence, empathy and altruism: Evidence from the Ivorian refugee crisis in Liberia". British Journal of Political Science, vol. 50, no. 2, 2020, pp. 731-755.

Haslam, S. Alexander, Stephen D. Reicher, and Michael J. Platow. The new psychology of leadership: Identity, influence and power. Hove, Psychology Press, 2010.

Hazlett, Chad. "Angry or weary? How violence impacts attitudes toward peace among Darfurian refugees". Journal of Conflict Resolution, vol. 64, no. 5, 2020, pp. 844-870.

Herrera, Marina, and Stephen D. Reicher. "Making sides and taking sides: An analysis of salient images and category constructions for pro-and anti-Gulf War respondents". European Journal of Social Psychology, vol. 28, no. 6, 1998, pp. 981-993.

Kaniasty, Krzysztof. "Social support, interpersonal, and community dynamics following disasters caused by natural hazards". Current Opinion in Psychology, vol. 32, 2020, pp. 105-109, https://doi.org/10.1016/j.copsyc.2019.07.026.

Kaniasty, Krzysztof, and Fran Norris. "The experience of disaster: Individuals and communities sharing trauma". Response to disaster: Psychosocial, community, and 


\section{Sandra Penić, John Drury and Zacharia Bady}

ecological approaches, edited by Richard Gist and Bernard Lubin, Psychology Press, 1999, pp. 25-61.

Kaplan, Oliver. Resisting war: How communities protect themselves. Cambridge, Cambridge University Press, 2017.

Kijewski, Sara, and Markus Freitag. "Civil war and the formation of social trust in Kosovo: Posttraumatic growth or war-related distress?". Journal of Conflict Resolution, vol. 62, no. 4, 2018, pp. 717-742.

Krakowski, Krzysztof. "Pulled together or torn asunder? Community cohesion after symmetric and asymmetric civil war". Journal of Conflict Resolution, vol. 64, nos 7-8, 2020, pp. 1470-1498.

Krause, Jana. Resilient communities: Non-violence and civilian agency in communal war. Cambridge, Cambridge University Press, 2018.

Levine, Mark, Amy Prosser, David Evans, and Stephen Reicher. "Identity and emergency intervention: How social group membership and inclusiveness of group boundaries shape helping behavior". Personality and Social Psychology Bulletin, vol. 31, no. 4, 2005, pp. 443-453.

Lewis, Justin. "Television, public opinion and the war in Iraq: The case of Britain". International Journal of Public Opinion Research, vol. 16, no. 3, 2004, pp. 295-310.

Linley, P. Alex, and Stephen Joseph. "Positive change following trauma and adversity: A review". Journal of Traumatic Stress: Official Publication of the International Society for Traumatic Stress Studies, vol. 17, no. 1, 2004, pp. 11-21.

Lock, Sarah, G. James Rubin, Virginia Murray, M. Brooke Rogers, Richard Amlôt, and Richard Williams. "Secondary stressors and extreme events and disasters: A systematic review of primary research from 2010-2011". PLoS Currents, vol. 4, 2012. doi:10.1371/currents.dis.a9b76fed1b2dd5c5bfcfc13c87a2f24f.

Lupu, Noam, and Leonid Peisakhin. "The legacy of political violence across generations”. American Journal of Political Science, vol. 61, no. 4, 2017, pp. 836-851.

Madlingozi, Tshepo. "On transitional justice entrepreneurs and the production of victims". Journal of Human Rights Practice, vol. 2, no. 2, 2010, pp. 208-228.

Mawson, Anthony R. Mass panic and social attachment: The dynamics of human behavior. London, Routledge, 2017.

Monroe, Kristen Renwick. "Cracking the code of genocide: The moral psychology of rescuers, bystanders, and Nazis during the Holocaust". Political Psychology, vol. 29, no. 5, 2008, pp. 699-736.

Ntontis, Evangelos, John Drury, Richard Amlôt, G. James Rubin, and Richard Williams. "Emergent social identities in a flood: Implications for community psychosocial resilience". Journal of Community \& Applied Social Psychology, vol. 28, no. 1, 2018, pp. 3-14.

Ntontis, Evangelos, John Drury, Richard Amlôt, G. James Rubin, and Richard Williams . "Endurance or decline of emergent groups following a flood disaster: Implications for community resilience". International Journal of Disaster Risk Reduction, vol. 45, 2020, https://doi.org/10.1016/j.ijdrr.2020.101493.

Nugent, Elizabeth R. After repression: How polarization derails democratic transition. Princeton, NJ, Princeton University Press, 2020.

Nussio, Enzo. "Can crime foster social participation as conflict can?". Social Science Quarterly, vol. 100, no. 3, 2019, pp. 653-665.

Penić, Sandra, Daniel Dukes, Guy Elcheroth, Sumedha Jayakody, and David Sander. "Beyond personal empathy: Perceiving empathy as socially shared predicts support for transitional justice mechanisms". Submitted. 
Penic, Sandra, Guy Elcheroth, and Davide Morselli. "Inter-group forgiveness in the aftermath of symmetric and asymmetric communal violence: Contact density and nationalistic climates as contextual mediators". European Journal of Social Psychology, vol. 47, no. 2, 2017, pp. 209-227.

Penić, Sandra, and Guy Elcheroth. "Shared diverse conflict memories predict community cohesion and psychological well-being". Paper presented at the annual conference of the International Society for Political Psychology on Polarization, Misinformation, and Entrenched Group Conflict: Harnessing Political Psychology to Find Solutions to Problems, July 14-16, 2020.

Penic, Sandra, Guy Elcheroth, and Dario Spini. "When is collective exposure to war events related to more acceptance of collective guilt?". Journal of Conflict Resolution, vol. 62, no. 1, 2018, pp. 143-173.

Penić, Sandra, Johanna Ray Vollhardt, and Stephen Reicher. "Reconciliation versus justice? It depends on the context: The role of symmetric and asymmetric violence in predicting postconflict attitudes”. Social Psychological and Personality Science, vol. 12, no. 2, 2021, pp. 202-212.

Penner, Louis, Michael T. Brannick, Shannon Webb, and Patrick Connell. "Effects on volunteering of the September 11, 2001, attacks: An archival analysis 1". Journal of Applied Social Psychology, vol. 35, no. 7, 2005, pp. 1333-1360.

Putnam, Robert. "A better society in a time of war". New York Times, 19 October 2001.

Quarantelli, Enrico Louis. "Panic, sociology of". International encyclopedia of the social and behavioural sciences, edited by N. J. Smelser and P. B. Baltes, New York, Pergamon Press, 2001, pp. 11020-11023.

Ramanathapillai, Rajmohan. "The politicizing of trauma: A case study of Sri Lanka". Peace and Conflict: Journal of Peace Psychology, vol. 12, no. 1, 2006, pp. 1-18.

Rauff, Salithamby Abdul, and Zulkarnain A. Hatta. "Armed conflict termination in Sri Lanka: An opportunity to end displaced life and renew Tamil-Muslim relations". Asian Social Science, vol. 9, no. 2, 2013, p. 219.

Reicher, Stephen, Clare Cassidy, Ingrid Wolpert, Nick Hopkins, and Mark Levine. "Saving Bulgaria's Jews: An analysis of social identity and the mobilisation of social solidarity". European Journal of Social Psychology, vol. 36, no. 1, 2006, pp. 49-72.

Rohner, Dominic, Mathias Thoenig, and Fabrizio Zilibotti. "Seeds of distrust: Conflict in Uganda". Journal of Economic Growth, vol. 18, no. 3, 2013, pp. 217-252.

Ross, Andrew A. G. Mixed emotions: Beyond fear and hatred in international conflict. Chicago, University of Chicago Press, 2013.

Shaw, Rosalind, Lars Waldorf, and Pierre Hazan, editors. Localizing transitional justice: Interventions and priorities after mass violence. Stanford, CA, Stanford University Press, 2010.

Skitka, Linda J. "Patriotism or nationalism? Understanding post-September 11, 2001, flag-display behavior". Journal of Applied Social Psychology, vol. 35, no. 10, 2005, pp. 1995-2011.

Spini, Dario, Guy Elcheroth, and Rachel Fasel. "The impact of group norms and generalization of risks across groups on judgments of war behavior". Political Psychology, vol. 29, no. 6, 2008, pp. 919-941.

Spini, Dario, Davide Morselli, and Guy Elcheroth. "War experiences and emerging rights claims in postwar former Yugoslavia: The role of generalized conflict exposure and collective anomie". European Journal of Social Psychology, vol. 49, no. 6, 2019, pp. 1173-1189. 


\section{Sandra Penić, John Drury and Zacharia Bady}

Surenthiraraj, Esther. Memory, rhetoric, and identity: A reading of Sri Lanka's postwar conjuncture. Unpublished doctoral dissertation, University of Lausanne, 2020.

Surenthiraraj, Esther, and Neloufer de Mel. "Two homes, refugees in both': Contesting frameworks - the case of the Northern Muslims of Sri Lanka”. Journal of Social and Political Psychology, vol. 7, no. 2, 2019, pp. 1044-1064.

Tekin, Selin and John Drury. "How can those affected by a disaster meet their needs for justice? Campaign strategies and partial victories following the Grenfell Tower fire". SocArXiv, November 15, 2020, doi:10.31235/osf.io/xrcfq.

Tellez, Juan Fernando. "Worlds apart: Conflict exposure and preferences for peace". Journal of Conflict Resolution, vol. 63, no. 4, 2019, pp. 1053-1076.

Thiranagama, Sharika. "Claiming the state: Postwar reconciliation in Sri Lanka". Humanity: An International Journal of Human Rights, Humanitarianism, and Development, vol. 4, no. 1, 2013, pp. 93-116.

Thiranagama, Sharika. In my mother's house: Civil war in Sri Lanka. Philadelphia, University of Pennsylvania Press, 2011.

Turner, John C. "The experimental social psychology of intergroup behaviour". Intergroup behaviour, edited by J. C. Turner and H. Giles, Oxford, Blackwell, 1981, pp. 66-101.

Vélez, María, Alejandra Carlos, Andres Trujillo, Lina Moros, and Clemente Forero. "Prosocial behavior and subjective insecurity in violent contexts: Field experiments". PloS one, vol. 11, no. 7, 2016.

Vollhardt, Johanna Ray. "Collective victimization". Oxford handbook of intergroup conflict. Edited by Linda R. Tropp, Oxford, Oxford University Press, 2012, pp. 136-157.

Weintraub, Stanley. Silent night: The story of the World War I Christmas truce. New York, Simon \& Schuster, 2001. 


\section{On the futures of reckoning with the past Neloufer de Mel and Guy Elcheroth}

Transitional justice stands, today, as the paradigmatic framework for justice after the atrocities of wars, genocides and human rights abuses of autocratic regimes. Reflecting on what it has so far achieved in a relatively short time span of three decades or so, Pablo de Greiff (2020) noted that it has "helped to give richer content to the notion of justice" by giving visibility to victims, shaping key elements in criminal justice, facilitating reparations, establishing forums for truth telling and mandates for institutional reform (p. 252). It has also bolstered, notes de Greiff, the entrenchment of rights to justice both in doctrine and practice, and has taught the criminal justice system how to cope with the consequences of amnesties and statutes of limitation, develop prosecutorial prioritization and provide plural formats for the delivery of justice (p. 252).

Ambitious projects, however, often court clay feet. It is possible to see, with the hindsight of three decades, that many of the "settlements" brokered by transitional justice's mechanisms have been partial, ambiguous and even contradictory. Their instability emerges from what de Greiff notes as challenges pertaining to all justice projects: "selectivity in the implementation of human rights norms, the tendency to 'securitize' all sorts of topics, and ... the "closing of civic space" (p. 253). In addition, transitional justice has been specifically vulnerable to an instrumental use of its mechanisms for political "turn-taking" and to paying insufficient attention to specific contexts, resulting in an "isormorphic mimicry", or belief that success in one place automatically translates as the same in another (pp. 254-55). This is a problem which de Greiff sees as also arising from donor agendas and the work of an elite global and mobile group of professionals within the field. What follows is that technicalities take over, in "an institutional engineering" that shapes questions such as how to set up a special court or truth commission, rather than what may be the best way of satisfying victims' rights to justice (p. 255).

The chapters in this volume uphold de Greiff's assessment of where transitional justice is at today, foregrounding in particular where it has failed its promise. In doing so they contribute to questioning, on a scholarly register, its framings and legacies, taking both a long, historical view and highlighting its current tendencies - be these mandates, implementation, intransigent

DOI: $10.4324 / 9781003167280-19$ 
contexts, racialized geographies, shifting goalposts, or sidelined local resources, groups and experiences. Briony Jones argued in Chapter 11 for working with resistance as a way of pointing to both the incomplete nature of "knowing" and revitalizing the field. The impulse of this book has been precisely this: taking seriously sources of disappointment and opposition, but also engaging with transitional justice towards repair, conceptual gain and course correction, rather than dismissing its legacy altogether.

A central tension within transitional justice, as pointed out in the different contributions in this book but particularly foregrounded in Tim Murithi's opening chapter, is of the emphasis on accountability and restoration of order based on a unifying master narrative versus a reckoning with the past that is more inclusive of different points of view, ethical choices and ways of remembering. While the first demands certitude, the latter acknowledges the need for an open-ended process, prone to contestation as varied memories and narratives of the past find their voice. In societies that have gone through the atrocities of apartheid, genocide or civil warfare, the notion of transition - to a new regime or to post-war reconstruction - carries the comforting certitude that the tragedy belongs to the past, and that a moral and social victory draws a firm line between a divisive past and a consensual present. Celebrating victory over a past that is "over" too quickly can come at a cost however, especially when forms of injustice bigger than what can be undone during an "extraordinary" transitional justice process, with a short-term mandate, are part of the problem. As Rothberg (2019, p. 15) noted, citing Robert Meister (2011, p. 26), rapid reconciliation based on a common understanding that "the evil is past" can be a questionable priority when it implies foregoing the necessary quest for social justice between the groups that structurally benefited from criminal regimes and those that were harmed.

The three contributions to the first section of this book provided vivid accounts of how official consensus that "the evil is past" has been achieved after apartheid in South Africa (Chapter 2), after the genocide in Rwanda (Chapter 3) and after civil war in Sri Lanka (Chapter 4), resulted in social fallout. Interestingly, while political will to create consensus is clearly discernible through each of these three cases, the relationship with human rights discourse appears more complex. While the South African Truth and Reconciliation Commission (TRC) clearly foregrounded a language of human rights, Rwanda's multi-modal transitional justice experiment unfolded through a complex mixture of running with the "global norm" and denouncing its limitations, whereas the war-winning Sri Lankan government took a path of open opposition to transitional justice delivered in the name of international human rights norms (and to international institutions, such as the United Nations Human Rights Council). One thing we can learn from these three cases placed side-by-side is that the declaration of "moral victory", and the simultaneous postponement of "material redistribution", can come in different guises. Human rights is only one of the languages mobilized to 
prioritize reunification (on the terms of the victorious regime or coalition of forces) over social and economic transformation. Depending on particular political configurations and histories of struggle, appealing to collectively cherished ideals of national emancipation and sovereignty, for example, can serve similar functions of rallying a broad spectrum of actors around chosen priorities.

The parallel (or sequential) tracks of special courts seeking accountability for extraordinary violence, and truth commissions for reckoning, dialogue and the admission of "smaller" crimes as windows into larger patterns, might be seen as transitional justice's current best answer to tackle the potentially contradictory imperatives of settling certainties and opening up diverse perspectives. The two routes are, however, interlinked. Even though they abide by distinct evidentiary processes, their respective focuses draw upon each other to create a bigger picture. This is because the extraordinary violence adjudicated in transitional justice courts is scripted on the "slow violence" which Rob Nixon (2011) writes of in another context (of ecological destruction), but which has a bearing on what we discuss here. Here, "slow" stands for the structural violence audible, for instance, at TRCs, which provides a context and template for the proliferating and acute forms of violence (pp. 2-3).

Attentiveness to the longue durée of violence inevitably raises questions about responsibility. Michael Rothberg's (2019) recent discussion of the "implicated subject" is particularly instructive here. The implicated subject is both real people in situated, material contexts who bear responsibility, for example as descendants and/or beneficiaries of systems of political violence, economic privilege, social discrimination, ecological plunder and so on, as well as "a trope for describing a contingent, shifting, and socially constituted position in that world". The implicated subject stands, therefore, for a broader reckoning of both slow, attritional forms of violence - the historical harms of racism, casteism, slavery and colonialism - and of the violence of war economies, corruption, ecological destruction, indebtedness and distributive distortion (Arbor 2007; Mani 2008; Duthie 2008; Gready and Robbins 2014; Urban-Walker 2016). Accountability and reparation for both of these sets of harms have yet to take place, however, on a meaningful scale. The contributions to the second section of this book vividly illustrated what can be the price for such oversights in the delivery of transitional justice. This ranges from societies that remain segregated along the same lines along which the economic crimes have been committed historically (which are racial lines in the case of South Africa, as discussed by Durrheim and Murray in Chapter 5), to post-generations which are made, in the best of cases, to claim rights responding to the trauma of their parents rather than to the inherited challenges of their own living circumstances (Chapter 6), or victim-survivors left with a potentially inflammatory combination of a language of virtuous struggle and an unfulfilled promise of justice (Chapter 7).

According to Rothberg (2019, p. 10), traditional forms of accountability for past misdeeds struggle to repair the harms of structural violence (such as 


\section{8}

economic crimes) because the spectrum of actors involved is discomforting, and responsibility is elusive as long as the spotlight is on individual victims and perpetrators. The figure of the implicated subject represents, therefore, "not a solution but a problem" (p. 200), a nettle transitional justice has yet to fully grasp. The challenges range from denial to scope: the "breadth of implication in a globally connected world" (p. 200), and the elusiveness of its " "agents' ... [who] appear on the surface amorphous - more faceless and nameless - than the perpetrators of legally defined and proscribed violations" (Mani 2008, p. 255). To ignore these interlinked structural harms, to highlight civil and political rights over socio-economic and cultural rights, is, however, to risk losing credibility in the very societies that transitional justice aims to benefit (Arbor 2007; Mani 2008). As Gready and Robbins (2014) noted in their call for a shift from transitional to a more transformative justice, a "new agenda of practice" has become necessary. This demand also implies a call for research as a critical practice on, and for, transitional justice that would find new and persuasive ways of analysing implication and responsibility.

Working with complex forms of implication in past injustice is also a condition for the inclusion of groups whose trajectories belie the victim-perpetrator binary, such as the former combatants discussed by Usoof-Thowfeek and Gunasekera in Chapter 10, whose pathways in and out of combat have been marked by manifold forms of coercion and violence. Relatedly, it provides a context to the experiences of actors kept "at a distance" in current ways of delivering justice, either literally, as a consequence of conflictgenerated exile (Chapter 8), or when the gap between the legal procedures of justice and cultural expectations of justice seems insurmountable (Chapter 9). It thereby opens up hitherto under-explored possibilities for building more inclusive processes for addressing past injustice, which are not only premised on the establishment of proof for individual guilt, adversariality or individual entitlement for reparation, but also collective patterns of historic violence whose consequences span into the present. To be of pragmatic and ethical value, these processes have to foreground the ethical, social and political alliances capable of undoing, here and now, the consequences of past injustice and facilitate what Rothberg $(2019$, p. 12) dubs long-distance solidarity between diverse groups of beneficiaries and victims who move towards each other in a joint commitment to create fairer structures.

This volume coalesced around the scholars, themes and issues that both framed and emerged from the Lausanne Summer School on Transitional Justice and Conflict Transformation, and the Pluralistic Memories Project from which the summer school emanated, and the chapters reflect this orientation. They offer insights on how group psychology, commemoration, justice beyond the law, combatant reintegration, victim solidarities, diasporas and postgenerations can add to the reconceptualization of transitional justice. They pay less attention, therefore, from a disciplinary lens of, say, developmental or political science, or legal or security studies, to questions 
on post-war development, institutional reform (including constitutional, legal and security sector restructuring), or the consolidation of democracy and good governance. They stay interested in these topics, however, given their intersections with the case studies at hand. Nor do they discuss at length cultural work for peacebuilding and long-term change which de Greiff (2020) rightly notes as "the least developed in terms of doctrine and practice" within transitional justice (p. 257); an observation endorsed in Chapter 3 on how individual commemorations on the Rwandan genocide through music and art were overshadowed by official top-down imperatives of remembering. Nor do they analyse the anatomy of the state - or more precisely, how we may move beyond what Ruti Teitel (2014) once called "steadystate justice" (p. 4) to theorize the state not as an abstraction (which thereafter permits its stability to be constructed), but as an "archipelago", or chain of logics incorporating the cultural/ethno-nationalistic, juridical, neoliberal and militarized, which combine and reconfigure contingently (Amar 2013).

Addressing such a state requires new vocabularies and schemas from transitional justice research including how we may avoid the ever-present nation-state which influences, also in this book, the identification of the particular case studies. Our intuitive understanding of what defines a "case" is typically bounded by the notion of a sovereign territory, even when some case studies are comparative, or include diasporas and groups that claim a right to return, or an anticipated state. For example, Parmentier, Rauschenbach and Hein's contribution (Chapter 8) showed not only how the taken for granted boundaries of national territories become visible (and problematic) once we take into account justice stakeholders located beyond these boundaries, but also why the analysis necessarily has to work with national frames as established social and political realities. We may not, therefore, want to dismiss the nation-state as a unit of analysis altogether given its primacy in international and humanitarian law) but, rather, we should be aware of the paradox of keeping to its borders when the nationalisms that underwrite its imaginaries have been turned into intractable grounds for violence.

To shed light on the unsettled nature of transitional justice, including research in the field, then, is to acknowledge that transforming injustice is, inherently, about work in progress. This refusal to settle often courts impatience. Noting that, because transitional justice can never fully redress all violations, de Greiff calls for a principled pragmatism invested in problemsolving and prevention of violence, rather than the utopianism he sees behind the endless rounds of critique that the human rights community has fallen prey to $(2020$, p. 257). The binary, however, between continuous critical reflection - which is also the habitus of research - and a pragmatic, ready-to-go practice on the basis of the gravities at stake, requires reframing. Qadri Ismail (2013), addressing a conference on "Ethical Futures", noted that if "one understands ethics, very crudely, as making a claim upon the good, and politics upon the possible, the statement challenges us to imagine 
the should, without being constrained by the could" (p. 2). Ethics is frequently aligned with justice; the "could" signals political conditions and judgements, and the "should" an anticipatory idealist promise. "Settlements" after systemic violence teach us, however, that neither the "could" nor the "should" is without politics.

Collective interpretations of what is desirable and feasible do not emerge in a vacuum, but are actively shaped and mobilized by those who have a stake in the outcome. Claims that peace is illusive (e.g. because the enemy is too hateful) or that a fairer distribution of privilege is out of reach (e.g. because people are intrinsically resistant to change) are typically easier to uphold than the claim that peace and equity are intrinsically unwanted. In democracy, everyone's view of what "should be" is meant to be given the same weight, but by orienting the collective perception of what "could be", influential elites can effectively bypass democratic aspirations. If one thinks (as we do) that scholars have a responsibility to facilitate transitional justice processes that are more democratic and inclusive, this aim certainly cannot be achieved through (technocratically) prescribing "the good", but rather by amending unduly narrow understandings of "the possible". In transitional justice, neglecting existing collective resources can sometimes lead to ignoring the potentially most desirable options prematurely, i.e. a failure even to consider them as serious options in the deliberative process.

The ethical and pragmatic implications highlighted in the four contributions presented in the final section of this book can, therefore, be far-reaching. They brought into consideration options traditionally viewed as impractical, such as working with spoilers (Chapter 11) or with people's capacity to connect with the suffering of communities different from their own (Chapter 12). They also revealed that what communities can become is not overdetermined, once and for all, by what they have been during the darkest (or brightest) hours of their collective trajectory. Communities can see their boundaries, values or capabilities shift in unpredictable ways by the experiences they go through collectively, be it by gathering at the same time and place as a crowd (Chapter 13) or by developing a sense of common fate throughout a wider pattern of events (Chapter 14).

Critically, therefore, these contributions have reminded us that the concept of transition applies equally to how we think about justice following violence, as well as to the needs of justice stakeholders and to the pathways available to meet these needs. Survivor expectations of, and settlements with, justice change over time. What someone feels is just when beginning a post-war life, for instance, may not be adequate justice later on in life. How justice is experienced, defined, promised and understood by different constituencies is shaped and measured along shifting individual and social relations. Therefore, creating justice in the aftermath of violence, whether we understand it as implication and responsibility (Rothberg 2019) or as ethical futures (Ismail 2013), is best thought of as a heuristic, rather than a point of resolution. It should be something that allows us to see further, and to open new 
pathways in the next act, rather than to celebrate victory or the final stroke of a pen on a peace agreement. What applies to the political holy grails that conflict actors strive for also applies to the intellectual ideal of conceptual definitiveness. The chapters in this book, therefore, in dialogue with each other as well as with other voices from within and without the transitional justice community, might offer the transitional justice field something more precious than new certainties: a nurturing of its continuous becoming.

\section{References}

Amar, Paul. The security archipelago: Human security states, sexuality politics, and the end of neoliberalism. Duke University Press, 2013.

Arbor, Louise. "Economic and social justice for societies in transition". International Law and Politics, vol. 40, no. 1, 2007, pp. 1-27.

Bell, Christine, Colm Campbell, and Fionnuala Ní Aoláin. "Transitional justice: (Re) conceputalising the field". International Journal of Law in Context, vol. 3, no. 2, 2007, pp. 81-88.

De Greiff, Pablo. "The future of the past: Reflections on the current state and prospects of transitional justice". International Journal of Transitional Justice, vol. 14, 2020, pp. 251-259.

Duthie, Roger. "Toward a development-sensitive approach to transitional justice". International Journal of Transitional Justice, vol. 2, 2008, pp.292-309.

Gready, Paul, and Simon Robbins. "From transitional to transformative justice: A new agenda for practice." International Journal of Transitional Justice, vol. 8, 2014, pp. 339-361.

Ismail, Qadri. On (not) knowing one's place: A critique of cultural relativism. Working paper series, no. 4, International Centre for Ethnic Studies, 2013.

Mani, Rama. "Dilemmas of expanding transitional justice or forging the nexus between transitional justice and development". International Journal of Transitional Justice, vol. 2, 2008, pp. 253-265.

Meister, Robert. After evil: A politics of human rights. Columbia University Press, 2011.

Nixon, Rob. Slow violence and the environmentalism of the poor. Harvard University Press, 2011.

Rothberg, Michael. The implicated subject: Beyond victims and perpetrators. Stanford University Press, 2019.

Teitel, Ruti G. Globalizing transitional justice: Contemporary essays. Oxford University Press, 2014.

Urban-Walker, Margaret. "Transformative reparations?: A critical look at the current trend in thinking about gender-just reparations". International Journal of Transitional Justice, vol. 10, 2016, pp.108-125. 


\section{Index}

Abahlali baseMjondolo 97, 100

abduction and murder, narrative on 128-30, 131, 132, 133-4

Abeyratne, Sirimal 173

Abeywardena, Sandani 126

Acar, Yasemin Gülsüm 15, 183-96

Acar, Y.G. and Coşkan, C. 193

Acar, Y.G. and Reicher, S.D. 185-6, 193

Acar, Y.G. and Sandal Önal, E. 191

Acar, Y.G. and Uluğ, Ö.M. 185, 187, 188

accountability 54, 80,114, 133, 139,

176-7, 216-17; criminal accountability

$118,120,128$; justice and 110, 125;

lack of 121-2; legal accountability 36 ,

111-12, 118; order restoration and

216; reparations and 217; resistance to

58-9; tension between

commemoration of past violations

and 21 ; traditional forms of,

weaknesses of 217-18. see also

criminal accountability

Adaderana 58

Adamson, Fiona 119

Adelman, L., Leidner, B., Ünal, H., Nahhas, E. and Shnabel, N. 176

Adou Djané, D.F. and Jones, B. 162

Adou Djané, Dit Fatogoma 162, 163, $165 \mathrm{n} 2$

Affected Women's Forum in Sri Lanka 125

Africa Confidential 164

African National Congress (ANC) 4, 27-8, 91-2, 95-6

African Union (AU) 29; Côte d'Ivoire and 161

Akindès, Francis 163

Alagiah, George 57

Aldrich, D.P. and Meyer, M.A. 198

Alexander, Neville 22
Alfadhli, K. and Drury, J. 206

Alfadhli, K., Cakal, H. and Drury, J. 206

All Ceylon Buddhist Congress 54

Allport, Gordon 68-9

Amar, Paul 219

Amarasingam, Amarnath 109

Amnesty International 113, 132

Anderson, Benedict 184

Anketell, Niran 52

anti-immigrant violence: nationalism and 96; phenomenon of $83,92,94,95$, 96, 98, 99, 100

anti-Muslim sentiment in Sri Lanka 56

Antonovskaya, Vasilina 141

Apartheid Guns and Money (Van

Nuuren. H.) 31

apartheid in South Africa: apartheid project, implementation of (1948-94)

22-3, 70-71; apartheid system, racialized segregation and 70-71; celebration of end of 21-33;

effectiveness in moulding minds 23 ; memory and 22-4; nation divided during time of 23-4; race identities, apartheid system and 24

Apartheid Museum in Johannesburg 28

Aranthalawa, massacre of Buddhist monks in (1987) 55

Arbor, Louise 32, 217, 218

Archaeological Heritage Management in Sri Lanka, Presidential Task Force for 58

Argentina: Comisión Argentina de Derechos Humanos 113; Comisión de Ex-exiliados Argentinos por la Reparación (CER) 114; Comisión de Exiliados Argentinos en Madrid (CEA-M) 114; Comisión de Exiliados 
Políticos de la República Argentina (COEPRA) 114; diaspora communities in transitional justice, case of 109-10, 111-12, 113-14, 116, 118-20; Hijas y Hijos del Exilio organization in 113-14; memories of repression in, repositioning of exiles in 113-14; National Commission on the Disappearance of Persons (CONADEP) 110, 111; Reparación al Exilio (1998) in 114; transitional justice in, early cases of 158

Arjona, Ana 197

armed conflict 2, 12, 131, 180; civilians as passive victims of 197, 207-8; injustice resulting from 117 ; internecine conflict 25 ; roles in, dealing with differences in 171-2; Sinhala Buddhist-Muslim conflict in Sri Lanka 55-6; South Sudan, conflict in 172; ubiquity in conflict settings 208; victim-survivors of conflict-related violence 125

Armenian genocide, Turkey and 176

Armenian Weekly 176

Arndt, Jochen S. 70

Ashworth, Tony 203-4

Athas, Iqbal 57

Auerbach, Yehudith 174

Azmi, Fazeeha 144

Bady, Zacharia 15, 197-214

Bagilishya, Déogratias 39

Bah, Abu Bakkar 161

Baines, E. and Stewart, B. 46

Bakke, K.M., O'Loughlin, J. and Ward, M.D. 202-3, 205

Bala, Mytili 176

Balasco, Lauren Marie 2

Baldo, Suliman 161

Baldwin, Gretchen 36, 41, 45, 46

Ballard, R. and Jones, G.A. 72, 73

Ballard, Richard 71, 72

Banny, Konan 162

Bar-Tal, D., Oren, N. and Nets-Zehngut, R. 205

Barber, B.K. and Doty, S.B. 200

Barchiesi, Franco 26

Barclay Child, T. and Nikolova, E. 202

Barlow, F.K., Paolini, S., Pedersen, A., Hornsey, M.J. et al. 69

Bauer, M., Blattman, C., Chytilová, J., Henrich, J. et al. 197, 200, 201, 202 BBC 44
Beavon, Keith 73

Bedoya, Nicolas 112

Belgium, special commission on colonial past in 2

belief in a just world (BJW), authority of law and 128-31

Bell, T. and Ntsebeza, D. 26

Bellamy, A.J. and Williams, P.D. 161

Bellows, J. and Miguel, E. 197, 203

belonging, material and symbolic 87

Ben-Josef Hirsch, Michael 3, 25

Benda, Richard 38

Bennett, T., Brems, E., Corradi, G., Nijzink, L. and Schotsmans, M. 158

Berdal, M. and Ucko, D.H. 138, 139

Beristain, Dr Carlos 117

Bermudez, Anastasia 110, 112-13, 114, 117

Bermùdez Liévano, Andrés 118

Bettencourt, L., Dixon, J. and Castro, P. 69

Bilali, R., Iqbal, Y. and Freel, S. 176

Bilali, Rezarta 178

Billig, M. and Marinho, C. 7, 12

Billig, Michael 8

Bizimungu, Julius 46

Bizimungu, Pasteur 38

Black Economic Empowerment (BEE) in South Africa 73

black inferiority, imposition in South Africa of 23-4

Black Lives Matter 6

Black Skin, White Marks (Fanon, F.) 23

Blackie, L. and Hitchcott, N. 38

Blakely, E.J. and Snyder, M.G. 72

Blandy, S. and Lister, D. 72

Blattman, Christopher 200

Blé Goudé, Charles 162, 164

Blitz air raids in World War II 207

Bodu Bala Sena (BBS) 55

Bolin, Annalisa 45

Bolzman, Claudio 107-8

Bosnia 2

Bradley, Megan 108

Breen, D. and Nel, J. 92-3

Breen, D., Lynch, I., Nel, J. and

Matthews, I. 93

Brounéus, Karen 4

Brun, Catherine 85, 206, 207

Buckley-Zistel, S., Coloma-Beck, T., Braun, C. and Meith, F. 24

Buckley-Zistel, Susanne 36-7

Buddhism 18, 55, 56-7, 59-60, 127; All Ceylon Buddhist Congress 54; 
Buddhist majoritarianism in Sri Lanka 59; Buddhist Power Force (BBS) in Sri Lanka 55, 56; hatred, perspective on harmful nature of 128 , 129-30; temples in Sri Lanka, Hindu objections to erection of 58. see also Sinhala Buddhism

Bunting, Brian 23

Bureau of the Commissioner General of Rehabilitation (BCGR) in Sri Lanka $142-3,145$

Burnet, Jennie E. 4, 36, 37, 38, 40

Burundi 204

Buxton, Rebecca 6

Cakal, H., Hewstone, M., Schwär, G. and Heath, A. 69

Çalikşkan, Dilara 83

Campbell, C. and Turner, C. 158 capital flight, "white flight" and 71-2 celebration 6-7; apartheid in South Africa, celebration of end of 21-33; turning commemoration into 14,60 ; victory celebration and unmaking of diversity in post-war Sri Lanka 51, 52, $55,57,58,59-60$

Cell, John Whitson 70

Centre for Policy Alternatives 51, 55

Chauke, Paballo 95, 100

Choi, J.-K. and Bowles, S. 200, 202

Christopher, Anthony John 68, 71, 172

Cilliers, Charles 29-30

Citizens' Commission in Sri Lanka 206, 207

citizenship: citizens' rights, xenophobia and 96-7; citizenship problem in South Africa 95-6, 99-100; citizenship rights 87 ; language rights of citizens 129

Civil Defence Force (CDF) in Sri Lanka $126,134 \mathrm{n} 6$

civil war $5,15,29,35,46,201,216$; in Côte d'Ivoire (2002) 161; decades-long civil war in Sri Lanka 79, 125, 140-41, 172-3, 176-7, 205-6; forceful recruitment of combatants in 139; intergenerational justice in Sri Lanka and 79; political violence and emergence of new identities following 205; reintegration for former combatants in Sri Lanka 140-41; in Rwanda 35-46; in Sri Lanka, triumphalist moment of 51-3; in
Sudan 172; women combatants in Ski Lankan civil war 125

Clark, Kenneth B. 68

Clarke, Lee 198

CNN 190

Cochrane, F., Baser, B. and Swain, A. 107

Cohrs, J.C., McNeill, A. and Vollhardt, J.R. 173, 174-5

Cole, Alixabeth R. 171

Coleman, Peter T. 138

collective interpretations, emergence of 220

collective psychosocial resilience:

political violence and 200-207; social identity model of 198-201

collective resilience 197-208; Blitz air raids in World War II 207; capacity of civilians in armed conflicts for, conflict transformation and 197-8; civilians as passive victims of armed conflict 197; collective victimization, effects of 202-3; collective violence, power of events of 205-6; "disaster communities" and 198, 199; Facebook groups 199; Grenfell Tower fire (2017) 200; identities, association with disasters 200; identities, inclusive identities, political violence and foregrounding of 202-5; identities, longevity of 206; identities, political violence and emergence of new identities 205-7; inclusive resilience, lived experiences of 205; inclusive social identities 203; intergroup conflicts and 205; Jordan, Syrian refugees in 206; locality, collective coping and 200; 9/11 attack on World Trade Centre 201; political violence, emergence of new identities and 205-7; political violence, foregrounding of inclusive identities and 202-5; political violence, reinforcement of shared social identity and 201-2; shared identity, solidarity and cohesion in 199; shared social identity, political violence and reinforcement of 201-2; shared social identity, solidarity and cooperation in 198-9; silencing of, risk for transitional justice in 208; social bonds, supportive behaviours and 198; social cooperation, prosocial behaviour and 197; social identity 
model of collective psychosocial resilience 200-201; social learning, stories of collective resilience as source for 208; Sri Lanka, Northern Muslims in 206-7; support, expectation of 199; targeted repression 202; trench warfare in First World War 203-4, 205; ubiquity in conflict settings 208; violence, collective exposure to asymmetric and symmetric, effects of 204; violence, indiscriminate imposition of 202; violence, organized communities and limitation of 201; violence, selective violence against civilians 202; York, floods in (2015-16) 199

collective victimhood 171-2; effects of collective victimization 202-3

Colombage, Dinouk 147

Colombia 201, 202-3; Commission for the Clarification of Truth, Coexistence, and Non-Repetition 111; diaspora communities in transitional justice, case of 10-11, 109-10, 112-13, 114-16, 116-18, 118-20; diaspora engagement in, fragmented nature of 114-15; exiles' organizations, transnational networks of 115; Foro Internacional de Victimas in 115-16; International Bureau for Human Rights Action on Colombia 115; memory as expression of rebellion against violence and impunity in 116-17; National Centre for Historical Memory (CNMH) 112, 115, 117; Oficina Internacional de los Derechos Humanos Acción in 115; Search Unit for Missing Persons and the Special Jurisdiction for Peace 111; Truth, Memory, and Reconciliation Commission of Colombian Women in the Diaspora 115-16; Truth and Reconciliation Commission (TRC) 117-18; truth-seeking initiatives, development of 115-16

colonial histories 160

colonialism 26, 29, 217

Colvin, Christopher J. 26, 164

Comisión Argentina de Derechos Humanos 113, 115

Comisión de Ex-exiliados Argentinos por la Reparación (CER) 114

Comisión de Exiliados Argentinos en Madrid (CEA-M) 114
Comisión de Exiliados Políticos de la República Argentina (COEPRA) 114

commemoration 2-8, 29, 35, 38, 46, 59, 184-5, 194, 219; alteration of context and recognition of Tutsi victimhood in Rwanda 40-41; in authoritarian contexts, challenges of 44-6; celebration, turning commemoration into 14,60 ; economic

commemoration 30-32; Facebook groups and 199; formal commemorations 7; genocide commemoration in Rwanda 36-7, 40-44; inclusive forms of 22 ; invasiveness of 3-5; memorialization and $21,24,27$; memorialization and, facilitation of 25-6; national commemoration $36,40,45$; politics of 56-8; processes of 23 ; remembrance reduced to 6-7; transformative potential of 32

Commission for the Clarification of Truth, Coexistence, and Non-Repetition in Colombia 111 communal forgiveness, acceptance and 148

constructive resistance and importance of not knowing in transitional justice 155-65; Argentina, early cases of transitional justice in 158; change, search for 157; colonial histories 160 ; consultancies to advise and direct transitional justice 155; Côte d'Ivoire: knowledge claims and justice politics 160-64; "foreign expert" and "local beneficiary," distinction between 157-8; "global norm" of transitional justice, critique of 157; Global South experiences 157; knowledge, monoliths of 157, 158-9; legal versus non-legal approaches 158; legitimacy of transitional justice, knowledge dimension and 157; order and closure, search for 156-7; resistance as object of inquiry in transitional justice 156, 159-60; resistance as way of not knowing transitional justice 159-60; rethink on transitional justice 155-6, 164-5; transitional justice, central tension (or contradiction) within 164-5; transitional justice and its politics of knowledge 156-9; transitional justice toolkits (United 
Nations) 155; "truth," search for 156-7, 164

Consultative Task Force (CTF) in Sri Lanka 54

"contact hypothesis," Allport's notion of 68-9

contact theory, problem of segregation and $68-70$

coordination, "horizontal" and

"vertical" forms of 113

corrective moral justice, aim of 22

Corry, A. and Khatib, S. 169

Côte d'Ivoire: African Union 161; civil war (2002) 161; Economic Community of West African States (ECOWAS) 161; economic prosperity and stability in 161; France, role in 161; knowledge claims and justice politics 160-64; National Program for Social Cohesion and national Security Council 162; Ouagadougou

Agreement (2007) 161; Parti

Démocratique de la Côte d'Ivoire 161; political violence (1990-2011) in 161;

Rassemblement Démocratique Africain 161; resistance to transitional justice, analysis of 163-4; resistances, contestations on transitional justice process 162-3; Rome Statute, ratification of 162; Special Inquiry and Investigation Unit on post-electoral crisis 162; "spoilers" of transitional justice 163; Truth and Dialogue Commission (CDVR) 162, 163-4; UN Human Rights Council 161; United Nations (UN) 161, 162; "victor's justice," narrative of 161. see also constructive resistance and importance of not knowing in transitional justice

coups: attempt in Turkey (July 2016) 190-91, 192; notion of 192

COVID-19 pandemic 55, 56, 148

criminal accountability: challenges of 133 ; in context of war 128 , 133

Crisp, R.J. and Turner, R.N. 69

critical questioning of transitional justice, relevance of 12-13

Croatia 2

Cronin-Furman, Kate 176

crowds and transformation of identities 183-94; collective priorities, shifts to 184; common experience, common repression and production of unity 187-90; common repression 188; "coup," notion of 192; coup attempt in Turkey (July 2016) 190; crowd events, boundaries of group inclusion and exclusion and 183; crowds, boundaries and intergroup conflict 189-90; crowds, Le Bon's perspective on 183; crowds and social identity 183-5; democracy, societal harmony and 188; "Democracy Watches" post-coup 2016 gatherings 183, 185-6, 190-93, 194; events at Gezi Park 186-7; gatherings for "Democracy Watch" 190-93; Gezi Park protests (2013) 183, 185, 186-90, 194; group identities, transformation of 184-5; Milliyetçi Hareket Partisi (Nationalist Movement Party) 191; prototypical "terrorist other" 193; proximity and commonalities in lived experience 188; psychological crowds 184; reconciliation and social identity 185-6; repression, Kurdish experience of 188; social identities, creation and change of 184; Turkey, entrenched divides in 188-9; Turkey, LGBT activism in 183, 185, 187, 189; Turkish nationhood, nature of 183; unity, common experience, common repression and production of 187-90; unity, diversity and 189

Crush, J. and Ramachandran, S. 93

Crush, Jonathan 26, 27, 92

Dalada Maligawa (Temple of the Tooth), attack on (1998) 55

Dancy, G. and Wiebelhaus-Brahm, E. 131

Darfur 202-3

Das, Veena 46

Davis, Natalie Zemon 184

De Greiff, Pablo 215, 219

De Mel, N. and Kodikara, C. 80, 132

De Mel, N. and Samararatne, D. 126

De Mel, Neloufer 1-18, 125-37, 215-21

De Ryck, P. and Lopez Villamil, S. 113

De Silva, C.R. 172

De Votta, Neil 57, 172-3

decolonization 29, 75n1, 94; decolonized education, call for 94; and end of white privilege, calls for 93

Degni-Ségui, René 35

Dell, M. and Querubin, P. 202 
demobilization, inclusive victimhood and $175-6,177$

democracy, societal harmony and 188

"Democracy Watches" post-coup 2016 gatherings 183, 185-6, 190-93, 194

Des Forges, Alison 35, 43

Dewasiri, Nirmal Ranjith 80

Dharmawardhane, Iromi 141

Di Pasquale, Caterina 10

Diallo, Youssouf 161

diaspora communities in transitional justice 107-20; Argentina, case of 109-10, 111-12, 113-14, 116, 118-20; Colombia, case of 10-11, 109-10, 112-13, 114-16, 116-18, 118-20; coordination, "horizontal" and "Vertical" forms of 113; diaspora and exiles, notion of 107; diaspora engagement, scholarship on 108; diaspora engagement in Colombia, fragmented nature of 114-15; "diaspora" history of notion of 107 ; discussion and lessons from cases 118-20; exiles' engagement, differences in 111-13; forgotten actors, diaspora communities as 107 , $118,119,120$; framings of past in diasporas' relations to transitional justice at home 109; identity development, diasporas and 107-8; memory as lynchpin of exiles' struggles for recognition 116-18; memory dimension 108-9; peace accords, participation possibilities for victims in 112-13; remembrance, role of 117, 119, 120; Sri Lanka, case of Tamils in 108-9; transitional justice strategies, diaspora engagement with 108; transnational networking initiatives 112-13; turning points and "transformative events," role of 111-13; types of diaspora mobilizations 113-16. see also Argentina; Colombia

Díaz Pabón, Fabio Andrés 110

Diken Turkey 193

disarmament, demobilization and reintegration (DDR) process: children in 144; difficulties for 139; facets of 138; forgotten actors, need for inclusion in 148; peacebuilding and 139; post-conflict peacebuilding and transitional justice, importance of programmes for 139-40; programs of
138-40, 141-2, 144, 148; reintegration and rehabilitation aspects of 139,141 ; reintegration aspect of 139; in Sri Lanka 138-40; state narrative on 141-2

"disaster communities," collective resilience and 198, 199

Dixon, J. and Durrheim, K. 3

Dixon, J., Durrheim, K. and Thomae, M. 68

Dixon, J., Durrheim, K. and Tredoux, C. 69

Dixon, J., Elcheroth, G., Kerr, P., Drury, J. et al. 12

Dixon, J., Levine, M., Reicher, S. and Durrheim, K. 169, 175, 177

Dixon, John 15, 27, 91-103

Dosdad, A.I. and Louidor, W.E. 115

Doughty, Kirstin 36, 46

Dovidio, J.F., Gaertner, S.L. and Saguy, T. 171

Drozdzewski, D., De Nardi, S. and Waterton, E. 37

Drury, J. and Reicher, S.D. 184, 194, 202, 205

Drury, J., Brown, R., González, R. and Miranda, D. 199

Drury, J., Carter, H., Cocking, C., Ntontis, E. et al. 198, 199, 202, 203, 206, 207

Drury, J., Cocking, C. and Reicher, S. 199, 201, 205

Drury, John 12, 15, 197-214

Du Bois, W.E.B. 68

Du Toit, F. and Doxtader, E. 25

Durington, Matthew 72

Durrheim, K. and Dixon, J. 69

Durrheim, Kevin 14, 27, 67-78, 217

Duthie, Roger 217

Easter Sunday carnage (2019) in Sri Lanka 59

Echterhoff, G.E., Higgins, T, and Levine, J.M. 10

economic commemoration 30-32

Economic Community of West African States (ECOWAS) 161

economic prosperity and stability in

Côte d'Ivoire 161

Edge City 73

Egypt 202

Ekneligoda, Prageeth 134n3

Elcheroth, G. and Reicher, S.D. 205

Elcheroth, G. and Spini, D. 205 


\section{Index}

Elcheroth, Guy 1-18, 203, 215-21

Elcheroth G. and Reicher, S.D. 11

Eltringham, N. and Van Hoyweghen, S. 36

eNCA 21

Eng, D. and Kazanjian, D. 127

Erdoğan, Recep Tayyip 176; crowds and transformations of identity 185,186 , 187, 190, 191, 192, 193

Estrada Rodriguez, J.A. and Aponte Otalvaro, J.E. 107, 111, 112, 117

ethics: ethical debates, necessity for 11 ; justice and 219-20, 220-21

ethno-religious nationalism in Sri Lanka $52-3$

Étiemble, Angélina 109

European Commission 6

European Court of Human Rights (ECHR) 177

European Union (EU) 113, 118, 120

Evans, Matthew 3, 70, 92, 158

Facebook groups 199

Fair, C., Littman, R., Malhotra, N. and Shapiro, J.N. 203

Families of the Disappeared in Sri Lanka 125

Fanon, Frantz 23, 68

Farley, R., Schuman, H., Bianchi, S., Colasanto, D. and Hatchett, S. 71-2

Fasel, Rachel 128, 130

Fatton, Robert Jr. 23

Feinberg, W.E. and Johnson, N.R. 198

Feldman, S., Huddy, L. and Marcus, G. E. 205

Felstiner, W.L.F., Abel, R.L. and Sarat, A. 131

Ferguson, N., Burgess, M. and Hollywood, I. 171

Fernando, Jude Lal 51

Fernando, N.J. and Jayatunge, R.M. 147

Fernando, Ruki 58

focus group discussions (FGDs): intergenerational justice $82,85-6,87$, 88; rural women, access to law for 127

Fonseka, B. and Raheem, M. 87

Fonseka, B. and Schulz, E. 126, 131

"foreign expert" and "local beneficiary," distinction between 157-8

forgotten actors 15, 142, 148; diaspora communities as 107, 118, 119, 120

Foro Internacional de Victimas in Colombia 115-16

France, role in Côte d'Ivoire 161
Franco, M. and Pérez, C. 113

Frankenberg, Günter 128

Frederickson, George 24

freedom, divergent understandings of 132

Freedom Charter (1955) in South Africa 67

Freedom Park in Pretoria 28

Freud, Sigmund 83

Friedman, Rebekka 132; reintegration of former combatance 139, 140, 144

Friedrich, M. and Johnston, T. 36

Fritz, C.E. and Williams, H.B. 198

Fritz, Charles E. 197

frontiers: migration and race attitudes on colonial frontier and beyond 70-71, 72; segregation, new frontier for $73-4$

Gacaca tribunals in Rwanda 4, 132

Gaertner, S.L. and Dovidio, J.F. 198

Gaertner, S.L., Dovidio, J.F., and Bachman, B.A. 69

Gáfaro, M., Ibáñez, A.M. and Justino, P. 197

Gahima, Gerald 36

Galanter, Marc 126

Garagozov, Rauf 170

Garcia-Godos, J. and Sriram, C.L. 138-9

Gardiner, Juliet 207

Garreau, Joel 73

Gasana, Oscar 43

gated communities, exclusive estates and $68,72-3,73-4$

Gbagbo, Laurent 160-61, 162-4

Gbagbo, Simone 162

Gelvin, James L. 185

Gender Justice and Security Hub

(GCRF) project 134n5, 135

génocidaires in Rwanda 4, 40, 43-4

genocide in Rwanda: Catholic diocese's

recognition of mass atrocities and

39-40; commemoration of 35-46; first

national genocide commemorations

37-40; Hutu Power and 35-6; mass

atrocity of 36 ; official genocide

commemoration in Rwanda, themes

in literature on 37; survivors' associations, government partnership with 38-9

Germany, society post World War II in 6

Gezi Park in Istanbul, protests at (2013)

$183,185,186-7,188-9,190-91,192$, 193-4 
Gilligan, M.J., Pasquale, B.J. and Samii, C. 197, 200, 203

Gillis, John R. 184, 194

global inclusive victim consciousness 170

"global norm" of transitional justice, critique of 157

Global South experiences 157

Glynn, S.A., Busch, M.P., Schreiber, G. B., Murphy, E.L. et al. 201

Gobodo-Madikizela, P. et al. 30

Gomez, Mario 141

Governeur, Cédric 51

Gready, P. and Robins, S. 2, 32, 92, 197, 217, 218

Gready, Paul 2, 3, 91, 133

Greater Gauteng Business Forum (GGBF) in South Africa 97-8

Greenaway, K.H., Louis, W.R. and Wohl, M.J.A. 175

Greenaway, K.H., Quinn, E.A. and Louis, W.R. 175

Greenwood, Ronni Michelle 171

Grenfell Tower fire (2017) in London 200

Grimm, A., Hulse, L., Preiss, M. and Schmidt, S. 198

Groundviews 53

group identities: boundaries and, redefinition in conflict of 172 ; in conflict, salience of $172-3$; transformation of $184-5$

group narratives: high-power group narratives 175-6; low-power group narratives 177

Guichaoua, André 35, 38, 44

Gül, M., Dee, J. and Cünük, C.N. 186

Gülen, Fethullah 190

Gunasekera, V. and Pathiraja, K. 141, $144,145,146$

Gunasekera, Viyanga 15, 138-51, 218

Gunasinghe, Newton 79

Guyer, Sara 36

Habib, Adam 94

Habyarimana, Juvénal 35, 38

Hager, A., Krakowski, K., and Schaub, M. 202

Haider, Huma 107, 108

Haidt, Jonathan 200, 202

Halilovich, Hariz 109

Hamber, B. and Wilson, R. 159

Hameiri, B. and Nadler. A. 170

Haniffa, Farzana 79, 81, 173, 207

Hansen, Thomas Obel 159
Happer, C. and Philo, G. 205

Harris, Bronwyn 92

Hartman, A.C. and Morse, B.S. 202

Hasbullah, Shahul H. 80

Haslam, S.A., Reicher, S.D. and Platow, M.J. 204, 205

hate crime 93. see also xenophobic violence

Hazlett, Chad 202

Hector Petersen Museum in Soweto 28

Hein, Laura 15, 107-24, 219

Heleta, Savo 93

Helms, Janet 23

Herrera, M. and Reicher, S.D. 205

Hettiarachchi, Malkanthi 141, 142, 143

Hijas y Hijos del Exilio organization in Argentina 113-14

Hirsch, Marianne 81-3, 84-5

Hoffman, Eva 83

Höglund, K. and Orjuela, C. 11, 141

Homelands 95

Hook, D. and Vrdoljak, M. 72

Houphouët-Boigny, Felix 161

human rights $25,28,32,118,119-20$; academic institutions and 115; claims for 11; human rights activism 120 ; human rights community 219; human rights law, criminal prosecutions and 113; human rights norms, selectivity in implementation of 215; legal remedies and 158; liberal human rights 132; peace, reconciliation and 203; transitional justice doctrine, liberal human rights and 132; violations of $46,57-8,108,110,112$, 113-14, 116, 119-20, 148, 155, 157-8, 176-7, 215; violations of, response to legacy of 32-3; violations of, victims of 91-2; wartime human rights violations, accusations of 52

Human Rights Commission 92-3

Human Rights Council 6

Human Rights Watch 51, 113

Hürriyet Daily News 191

Hutu Power in Rwanda 35-6

Hyndman, J. and Amarasingam, A. 5

Ibreck, Rachel 36, 37, 40, 45

identities: association with disasters 200; dentity development, diasporas and 107-8; identity of rehabilitees, formalization of 145 ; inclusive identities, political violence and foregrounding of 202-5; inclusive 
social identities 203; longevity of 206; multiple intersecting identities 171 ; multiple intersecting identities, dealing with 171; political violence and emergence of new identities 205-7; reconciliation and social identity 185-6; shared identity, solidarity and cohesion in 199; shared social identity, political violence and reinforcement of 201-2; shared social identity, solidarity and cooperation in 198-9; social identities, creation and change of 184. see also crowds and transformation of identities

implicated subject 217-218

inclusive narratives: risks of 169; of suffering 169-73; of suffering, selective or universal 174, 175; of suffering, Sri Lanka perspective on 176

inclusive resilience, lived experiences of 205

inclusive victim consciousness 169-71, $173-5,176,177$; on borders of Rwanda 173-4; what it is not 170-71 inclusive victim narratives $171-3,178$ inclusive victimhood: pitfalls of 175-7; promise of $173-5$

Indonesia 204

Ingabire, Victoire 44

Ingelaere, Bert 36

injustices $13,30,67,81,127-8,169,216$; armed conflict, injustice resulting from 117; chronic injustice 5-6; economic injustice 12, 24-5, 31; historical injustices 22, 27, 162; inequalities, divisions and 71 ; moral contradiction and sense if injustice 24; past injustices, potential for dealing with $26,28,32-3,218$; societal injustice 24-5; systemic injustice 1, 23; transformation of 219; wartime injustices 80

Institute for Justice and Reconciliation (IJR) in South Africa 22, 23

intergenerational justice 79-89; belonging, material and symbolic 87 ; four-part focus group discussions (FGD) 82, 85-6, 87, 88; memory, connection and burden, memory as 83-8; memory, "duty to remember" for sake of justice 81 ; memory, right to redress and 86-8; memory, tension between remembering North and focus on Puttalam 88; post-war recovery, panaceas for 80 ; postmemory, concept of 82-3; Puttalam district in Sri Lanka 80-81, 82, 84, 85-7, 88, 89; return and postgenerations in Puttalam 84-5; rights and reparations, memory as validation for demand for 81-2; Sri Lanka, contentious history of transitional justice in 80; Sri Lanka, displacement of Northern Muslims in 81; Sri Lanka, ethnic cleavages in 79; Sri Lanka, fault lines in, social entrenchment of 79; Sri Lanka, Puttalam district and Northern Muslims of 80-81; Sri Lanka, Sinhala-Tamil ethnic binary in $80-81$; trans-generational experiences, social markers of 85-6; transitional justice, origins of 79; transitional justice, war weary communities and planning of 79-80

intergroup configurations 12

intergroup conflicts, collective resilience and 205

intergroup contact, racialized privilege and $74-5$

intergroup relations after conflict, effects of inclusive victimhood on 173-5

International Bureau for Human Rights Action on Colombia 115

International Center for Transitional Justice (ICTJ) 111, 133, 134-5n18

International Criminal Court (ICC) 162, 164

International Criminal Tribunal for Rwanda (ICTR) 36, 40

International Criminal Tribunal for the former Yugoslavia 2

International Crisis Group 52, 125

International Victims Forum 115-16

Ismail, Qadri 219-20

isomorphic mimicry 215

Israel: Alternative Memorial Day in 169; commemoration in 4; Israeli-Palestinian conflict 173

\section{Janatha Vimukthi Peramuna (People's} Liberation Front) in Sri Lanka 54; insurrection by 142

Jayakody, S. and Penić, S. 176, 177

Jayakody, Sumedha 15, 169-82

Jayasundere, R. and Valters, C. 125-6 Jayasuriya, Ranga 52

Al Jazeera 44 
Jelin, Elisabeth 108

Jenoside yakorewe Abatutsi ("genocide against the Tutsi"). in Rwanda 40

Jensen, Silvina 107, 112, 116

Jessee, Erin 4, 14, 35-50

Jimeno, Eliana 108

Jonas, Mcebisi 92

Jones, B. and Adou Djané, D.F. 163, 165

Jones, B. and Bernath, J. 156, 159, 160

Jones, B. and Lühe, U. 156, 157

Jones, Briony 15, 155-68, 216

Jordan, Syrian refugees in 206

Jung, C. and Shapiro, I. 91

justice: access to law as justice, stages for 131; broken promise for women of 131-2; corrective moral justice, aim of 22; cultural expectations of, gap between legal procedures and 218 ; distributive justice 22; effects on women of broken promise 131-2; ethics and 219-20, 220-21; immanent and ultimate 130; justice postponed, societies caught in transition and 3; pragmatic approach to 127-8; in Sri Lankan border village, understandings of 126-8; transition, application of concept to justice following violence 220-21

Justice and Development Party (AKP) in Turkey 187, 189, 190, 191, 192, 193

Kabir, Sarah 144

Kafka, Franz 129

Kagame, Paul 4; genocide in Rwanda, commemoration of $35,36,38$

Kagoro, Brian 157

Kandy, Temple of the Tooth in 55, 57

Kaniasty, K. and Norris, F. 198, 199, 201

Kaniasty, Krzysztof 199

Kaplan, Hasan 128

Kaplan, Oliver 201, 202

Kapur, Ratna 132

Karabegovicć, Dženeta 109, 120

Keck, M.E. and Sikkink, K. 120

Kelsall, Tim 132, 158

Kemal Atatürk, Mustafa 186, 191

Kende, J., Phalet, K., Van den Noortgate, W., Kara, A. and Fischer, R. 69

Kenya, Truth and Reconciliation Commission (TRC) in 1-2, 21
Kerr, P. and Durrheim, K. 98-9, 100

Kerr, P., Durrheim, K. and Dixon, J. 3; non-citizens' rights $95,98,100$

Kerr, Philippa 15, 27, 91-103

Khalili, Lalch 3

Khan, I., Minhas, A.S. and Satt, H.N. 144

Kibuye Roman Catholic Church, testimony of survivor of massacre at 38-9

Kigali Genocide Memorial, Victoire Ingabire's speach at (2010) 44

Kigali National Amahoro Stadium, first national genocide commemoration in (1995) 38

Kijewski, S. and Freitag, M. 202

Kimonyo, Jean-Paul 35

King, Elisabeth 36

Kirshner, Joshua 100

Klar, Y., Schori-Eyal, N. and Klar, Y. 4

Kleinman, Arthur 46

Klinsky, S. and Brankovic, J. 6

knowledge 156, 159; knowledge claims and justice politics in Côte d'Ivoire 160-64; monoliths of 157, 158-9; selective politics of 164

Kochanski, Adam 4, 11

Koinova, M. and Karabegovic, D. 109, 119

Koinova, Maria 119

Konya, Nazh 191, 192

Krakowski, Krzysztof 202

Krause, Jana 204, 208

Krishanthi Kumaraswamy case 126, $133-4 \mathrm{n} 2$

Krishnan, Sonny Inbaraj 144, 146

Kruglanski, A., Gelfand, M.J., Bélanger, J.J., Gunaratna, R. and Hettiarachchi, M. 143

Kruglanski, Arie 143

Kubai, Anne 40

Kurdish Workers' Party (PKK) in Turkey 193

Kwibuka 26, launch in Rwanda of 35, 36

labour struggles, xenophobic violence and 98-9

Lacroix, T. and Fiddian-Qasmiyeh, E. 108

Landau, Loren 92, 93, 100

language: language rights of citizens 129; locution at heart of law's grammar 131 


\section{Index}

Lausanne University Summer School on Transitional Justice and Conflict Transformation 13, 218-19

Laws, M., Ntakirutimana, R. and Collins, B. 36

Le Bon, Gustave 183

Leach, C.W. and Allen, A.M. 175

Lecamwasam, Nipunika 177

Leebaw, Bronwyn 32

legal authority, belief in a just world (BJW) and 128-31

legal versus non-legal approaches to transformative justice 158

Lemanski, Charlotte L. 71, 72, 73

Lemanski, C.L., Landman, K. and Durington, M. 72-3, 74

Lemmer, G. and Wagner, U. 69

Lesbian, Gay, Bisexual and Transgender (LGBT) activism 183, 185, 187, 189

Lessons Learned and Reconciliation Commission (LLRC) in Sri Lanka 53

Levine, M., Prosser, A., Evans, D. and Reicher, S. 198

Lewis, J. and Knight, J. 36

Lewis, Justin 205

liberation 100, 160; anti-apartheid liberation struggle 28 ; liberation movements 28; liberation struggle and transitional justice, practices of 94-5

Liberation Tigers of Tamil Ealam (LTTE) 125, 206; inclusive narratives of suffering 173, 176, 177;

intergenerational justice in Sri Lanka $79,80,81,83,87$; reintegration of former combatants 140-41, 142, 144, $145,146,148$; victory celebration and unmaking of diversity in post-war Sri Lanka 51, 52, 55, 57, 58, 59-60

Liberia 202-3

Licata, L. and Klein, O. 8

Linley, A.P. and Joseph, S. 200

Lipkus, I.M., Dalbert, C. and Siegler, I. C. 128

Lishivha, Welcome 75n1

Theory of Literary Production (Macheray, P.) 7-8

Little, Adrian 159

livelihood challenges for former combatants 145-6

local government elections in Sri Lanka (2018), results of 55

locality, collective coping and 200

Lock, S., Rubin, G.J., Murray, V., Rogers, M.B. et al. 199
Longman, T. and Rutagengwa, T. 37

Longman, Timothy 40

Low, Setha M. 72

Lupu, N. and Peisakhin, L. 200

Lutz, E. and Sikkink, K. 113

Maatram in Sri Lanka 125

McAuliffe, Padraig 155, 157, 159

MacCrone, I.D. 70

McDowell, Christopher 109

McEvoy, K. and McGregor. L. 108

McEvoy, K. and McGregor, L. 158

McEvoy, Kieran 158

McGilvray, D.B. and Raheem, M. 79

McGovern, Mike 161

Macheray, Pierre 7-8, 12

McKnight, Janet 4

McNeill, A. and Vollhardt, J.R. 169, 176

McNeill, A., Pehrson, S. and Stevenson, C. 175

Madlingozi, Tshepo 92, 93, 157, 197

Maes, J. 130

Maha Nayake Theras in Sri Lanka 57

Mahavämsa (Mahanama) 58

Mahindraratne, Prashanthi 134n4

Major, Laura 36, 38

majoritarianism: Buddhist majoritarianism in Sri Lanka 59; populist majoritarianism 55

Mamdani, Mahmoud 30, 91

Mandela, Nelson 4, 67, 91

Mani, Rama 32, 217, 218

Maoz, Ifat 69

Marsh, Elizabeth J. 9-10

Martin, Melissa 146

Martínez Leguízamo, Jeisson Oswaldo 107, 112-13

Mawson, Anthony R. 198

Maxwele, Chumani 93

Maylam, Paul 29

Mbembe, Achille 91, 93-4

Medawatte, Danushka 15, 125-37

Medhananda Thero, Venerable Ellawala 58

Meierhenrich, Jens 35, 36

Meister, Robert 216

memorialization: economic commemoration as act of $30-32$; memorials, displays of human remains at 42-3; problem of definitive identification of anonymous dead at memorials 44; spiritual dangers in memorial sites, perceptions of 43-4; 
Vidal's study of memorials in Rwanda 36-7

memories 6; absences in, searching for 7-8; collective memory 7; collective processes 8-9; connection and burden of 83-8; "duty to remember" for sake of justice 81 ; as expression of rebellion against violence and impunity in Colombia 116-17; as lynchpin of exiles' struggles for recognition 116-18; memory dimension for diaspora communities in transitional justice 108-9; of repression in Argentina, repositioning of exiles and 113-14; rights and reparations, memory as validation for demand for 81-2; right to redress and 86-8; "selective memories" 8 ; sharing of, transformative capacity of 9-10; silence, making sense out of 7-8; tension between remembering North and focus on Puttalam 88; truth, memory and quest for shared reality 8-10; Tuscany, shared memory of World War II massacre in 10

Michel, D.P. and Scott, D. 73

migration: creation of social justice and 69-70; in post-apartheid South Africa 71-3; social justice, persistence of racialized segregation and 70-71, $71-3,74$

military in Sri Lanka, challenges for and experiences of 144-7

Millar, Laura 8

Miller, Zinaida 158

Milliyetçi Hareket Partisi (Nationalist

Movement Party) in Turkey 191

Miriyagalla, Danura 146

Misago, Jean-Pierre 92, 93, 99, 100

Missing Persons, Office in Sri Lanka for $51,54,55,80,111$

Molefe, Osiame 28

Monroe, Kristen Renwick 203

Monson, Tamlyn 95

Motha, Stewart 128, 131

Muggah, Robert 138, 139

Murithi, Tim 14, 21-34, 71, 216

Murphy, Colleen 158

Murray, Amy Jo 14, 67-78, 217

Muslim community in Sri Lanka, post-war conflict with 59

Muslim Marriages and Divorce Act in Sri Lanka 56

Mwambari, David 36, 37
Nadarajah, S. and Sriskandarajah, D. 176

Nadarajah, Suthaharan 176

Nagy, Rosemary 155

Naidoo, Lee Anne 93

Nair, R. and Vollhardt, J.R. 170, 171

National Centre for Historical Memory $(\mathrm{CNMH})$ in Colombia 112, 115, 117

National Commission for the Fight Against Genocide (CNLG) in Rwanda 35, 36, 38, 40-41, 44-5

National Commission on the Disappearance of Persons (CONADEP) in Argentina 110, 111

National Program for Social Cohesion and National Security Council in Côte d'Ivoire 162

nationalism 46, 99, 219; "nationalismwithin-a-nationalism" in Rwanda, perpetuation of 36-7; populist nationalism 54

Nationalist Movement Party (MHP) in Turkey 191

Native Land Act (1913) in South Africa 22

N'Da, S.A. and Fokou, G. 164

negative moments, Mbembe's perspective on 91, 93-4

Neocosmos, Michael 95-6, 100n1

Network of Colombian Victims for Peace in Latin American and the Caribbean (Revicpaz-LAC) 115

Neville, F.G., Novelli, Drury, J. and Reicher, S.D. 184

New World Wealth 72

New York Times 201

Ngoga, Martin 40

Nhamuave, Ernesto 92

Nigeria 204

Nilsson, Anders 138

9/11 attack on World Trade Centre 201

Nixon, Rob 217

Njamnjoh, Francis B. 26-7, 29

non-citizens' rights 91-100; antagonisms, new to post-transition South Africa 93-5; anti-immigrant violence, nationalism and 96; anti-immigrant violence, phenomenon of $83,92,94$, 95, 96, 98, 99, 100; citizens' rights, xenophobia and 96-7; citizenship problem in South Africa 95-6, 99-100; decolonization and the end of white privilege, calls for 93; decolonized education, call for 94 ; 


\section{Index}

discussion, conclusion and 99-100; labour struggles, xenophobic violence and 98-9; negative moments, Mbembe's perspective on 91, 93-4; past, transitional justice and unfinished business of 91; residential racial segregation 92; transitional justice in South Africa, "negotiated revolution" of 91; transitional justice language, xenophobia and 97-8; Truth and Reconciliation Commission (TRC) process 91-2; xenophobia, pervasiveness of 100; xenophobia, transition between forms of 96 ; xenophobic violence, explosion of 92-3; xenophobic violence, roots of 95-6

Noor, M., Shnabel, N., Halabi, S. and Nadler, A. 171

Noor, M., Vollhardt, J.R., Mari, S. and Nadler, A. 169, 170

North Caucasus 202-3

Northern Ireland, conflict in 170, 171-2, 174-5

Northern Muslims 80-82, 84-89, 206-207

Nouwen, Sarah M.H. 157

Nowrojee, Biniafer 35

Ntontis, E., Drury, J., Amlôt, R., Rubin, G.J. and Williams, R. 199

Nugent, Elizabeth 202

Nuremberg trials 1-2

Nussio, Enzo 197

Nyamnjoh, Francis B. 67

Nyborg, Karine et al. 12

O'Connell, Siona 91

Occupied Palestinian Territories 3

Oficina Internacional de los Derechos

Humanos Acción in Colombia 115

order and closure, search for 156-7

Orjuela, Camilla 5, 80, 109

Ouagadougou Agreement (2007) 161

Ouattara, Alassane Dramane 161-4

Ozouf, Mona 185

Packard, Randall M. 71

Pagina 114

Palestine 3, 204-5; Alternative Memorial Day in 169; Israeli-Palestinian conflict 173

Palmary, Ingrid 92, 95, 97

Palmer, N., Jones, B. and Viebach, J. 158
Pancha Balavegaya (Five Great Forces) in Sri Lanka 56-7

Parasram, Ajay 5

Parmentier, Stephan 15, 107-24, 219

Parti Démocratique de la Côte d'Ivoire 161

past: past injustices, potential for dealing with 218; in South Africa, revisiting TRCs limited engagement with 27-32; transitional justice and unfinished business of the 91

Pasupathi, M., McLean, K.C. and Weeks, T. 8

Pasupathi, M., Stallworth, L.M. and Murdoch, K. 9

peacebuilding: long-term change and 219; peace accords, participation possibilities for victims in 112-13

Peiris, Kamalika 51

Penić, S. and Elcheroth, G. 205

Penić, S., Dukes, D., Elcheroth, G., Jayakody, S. and Sander, D. 205

Penić, S., Elcheroth, E. and Morselli, D. 203, 204

Penić, S., Elcheroth, G. and Spini, D. 203, 204

Penić, S., Vollhardt, J.R. and Reicher, S. D. 177,203

Penić, Sandra 15, 197-214

Penner, L., Brannick, M.T., Webb, S. and Connell, P. 201

People's Alliance for Right to Land in Sri Lanka 87

Peoples' Democratic Party (HDP) in Turkey 191, 193

Perera, Sasanka 140

Pettigrew, T.F. and Hewstone, M. 69

Pettigrew, T.F. and Tropp, L.R. 69

Pettigrew, Thomas F. 68

Pinochet, General Augusto 112

Pinto-Jayawardena, K. and Anantharajah, K. 126, 131

Pinto-Jayawardena, K. and Guthrie, J. 126

Pluralistic Memories Project (PMP) 13, 15-16, 89, 134n5, 204, 218-19

Poland, death camps in 4

political violence: collective psychosocial resilience, political violence and 200-207; in Côte d'Ivoire (1990-2011) 161; emergence of new identities and 205-7; foregrounding of inclusive identities and 202-5; identities, political violence and emergence of 
new identities 205-7; reinforcement of shared social identity and 201-2

politics 37, 72, 109, 144-6, 160, 161, 219-20; alternative politics of solidarity 97 ; of commemoration 56-8; contested politics 157, 159; economics and 30 ; identity politics 27 , 99, 208; political power and difficulties for transitional justice 11-12; political transition, regime change and 161; politics of knowledge, transitional justice and 156-9; politics of the "duty to remember" 127; selective politics of knowledge 164; Sinhala Buddhism, politics of 59-60; terror politics 60; transformative politics 140; war politics and new disparities 172; xenophobic politics 100. see also Côte d'Ivoire: knowledge claims and justice politics 160-64

Ponselet, Gaëlle 2

Portugal, revolution (1974) in 7

Posner and Vermeule (in Webber 2012) 132

post-apartheid South Africa: cities in, movement of capital from 73; racialized segregation in $71-4$

post-war recovery, panaceas for 80

post-war treatment of Tamils and Muslims in Sri Lanka 57-8

post-war victory celebration and unmaking diversity in Sri Lanka $51-60$

postgenerations $81-2,83,84-5,86,87$, $88,218-19$

postmemory, concept of $82-3$

Poulton, Hugh 185

poverty $22,25,73,93,97,131$; chronic poverty 95

power: Black Economic Empowerment

(BEE) in South Africa 73; Buddhist

Power Force (BBS) in Sri Lanka 55,

56; collective violence, power of events of 205-6; high-power group narratives 175-6; Hutu Power and genocide in Rwanda 35-6; low-power group narratives 177; political power and difficulties for transitional justice 11-12; power differences, inclusive victimhood and 175-7; power hierarchy of Sinhala Buddhism 59-60; research on, power dynamics of reintegration in Sri Lanka 143-4; state power 10, 218-19

prejudice reduction, effects of contact on 69

Premadasa, Ranasinghe 57

Presidency of Republic of Turkey 192

Prevention of Terrorism legislation in Sri Lanka 51, 55

principled pragmatism 219

problem-solving, de Greiff's call for principled pragmatism in 219

prototypical "terrorist other" 193

proximity and commonalities in lived experience 188

psychological crowds 184

punitive justice in South Africa 22

Putnam, Robert 201

Puttalam district in Sri Lanka 80-81, 82, 84, 85-7, 88, 89

\section{Quarantelli, Enrico Louis 198}

race and racism 99; anti-racism action plans 6; apartheid-generated racism in South Africa 25; historical harms of 217; internalized racism 95; race attitudes, social justice and 70-71; systemic racism in US 5-6

Raghavan, Suren 60n5-6

Rainbow Nation 27, 71, 74

Rajapaksa, Gotabaya 55, 57, 58, 59

Rajapaksa, Mahinda (and regime of) 52, $53,54,55,56,58$; honour of Vishwa Keerti Sri Sinhaladhishwara conferred on 57

Ramanathapillai, Rajmohan 8, 205

Ramaphosa, Cyril 52

Rassemblement Démocratique Africain in Côte d'Ivoire 161

Rauschenbach, M., Parmentier, S. and Van Craen, M. 108

Rauschenbach, Mina 15, 107-24, 219

reburials in Rwanda, commemorative initiatives and $39-40$

reconciliation and social identity $185-6$

Reconciliation Barometer (SARB, IJR) in South Africa 24, 27

Reddy, Thiven 27

Reeibeck, Jan van 22

rehabilitation: access to rehabilitees in Sri Lanka, research and 142-7; programme for, bolstering claim of efficacy of 143; and reintegration 


\section{Index}

within military in Sri Lanka 146-7, 148

Reicher, S., Cassidy, C., Wolpert, I., Hopkins, N. and Levine, M. 171, 203

Reicher, Stephen D. 171, 183-96

reintegration for former combatants in

Sri Lanka 138-48; access to

rehabilitees, research and $142-7$;

children in DDR process 144; civil

war 140-41; communal forgiveness

and acceptance 148; DDR process,

difficulties for 139; DDR process,

facets of 138; DDR process,

peacebuilding and 139; DDR process,

reintegration aspect of 139; DDR

process in Sri Lanka 138-40; female

ex-combatants, challenges for 146;

forgotten actors, need for inclusion in

DDR of 148; former combatants,

challenges for and experiences of

144-7; identity of rehabilitees,

formalization of 145 ; intractable

conflicts, effects of 138; livelihood

challenges $145-6$; military, challenges

for and experiences of 144-7;

post-conflict peacebuilding and

transitional justice processes,

importance of DDR programmes for

139-40; rehabilitation and

reintegration within military 146-7,

148; rehabilitation programme,

bolstering claim of efficacy of 143 ;

reintegration and rehabilitation

aspects of DDR 139, 141; research on,

power dynamics of $143-4$;

self-employment among

ex-combatants 145-6; state narrative

on DDR process 141-2; surveillance

of ex-combatants 144-5; transitional justice, inadequacy of normal justice systems and 138; unilateral victory of government forces 141, 144, 147, 176; work-related challenges 145-6

religious ethno-nationalism $52-3,58$

remembrance: collective remembrance 8 ; recollection, social practice of 9; role of, diaspora communities and 117 , 119,120 ; social psychology of 9 ; societal change and 6-12

Reparación al Exilio (1998) in Argentina 114

Reparations, Office in Sri Lanka for 51, $54,55,80$

repression, Kurdish experience of 188
Republican People's Party (CHP) in Turkey 187, 191, 193

resilience see collective resilience

resistance: contestations on transitional justice process 162-3; as object of inquiry in transitional justice 156 , 159-60; to transitional justice, analysis of 163-4; as way of not knowing transitional justice 159-60

retribution, notion of justice transcending 132

Rhodes, Cecil John 28-9, 93

The Cult of Rhodes: Remembering an Imperialist in Africa (Maylam, P.) 29

Rhodes Must Fall (RMF) as commemorative movement in South Africa 28-30, 75n1, 93

\#RhodesMustFall: Nibbling at a resilient colonialism in South Africa

(Njamnjoh, F.B.) 26

Richards, Joanne 140

Rieff, David 127

rights $94-5,99,216,217-18$; of black South Africans 100; citizens' rights, xenophobia and 96-7; citizenship rights 87; civil rights movement in US 68 ; cultural rights 218 ; to justice 215 ; justice and, demands for 45 ; to land 22; language rights of citizens 129 ; Muslim rights 207; reparations and, memory as validation for demand for 81-2, 88; socio-economic rights 218 ; war-time survivor, rights of 129 . see also human rights; non-citizens' rights

Rimé, Bernard et al. 12

Roberts, Michael 141, 144-5

Rohner, D., Thoenig, M. and Zilibotti, F. 200

Roht-Arriaza, Naomi 112, 113

Rome Statute, ratification of 162

Rose, Julia 37

Rosenthal, Lisa 171

Ross, Andrew A.G. 202

Rothberg, Michael 216, 217-18, 220

Rubli, Sandra 155

Rugira, Lonzen 40

rural women, access to law for 125-35; abduction and murder of husband, narrative on $128-30,131,132,133-4$; access to law as justice, stages for 131 ; Affected Women's Forum in Sri Lanka 125; belief in a just world (BJW), authority of law and 128-31; criminal accountability, challenges of 
133; criminal accountability in conyext of war 128, 133; displaced populations, women in 125; Families of the Disappeared in Sri Lanka 125; focus group discussions (FGDs) 127; freedom, divergent understandings of 132; hatred, Buddhist perspective on harmful nature of $128,129-30$; judicial bias against women 126; justice, broken promise of 131-2; justice, effects of broken promise of 131-2; justice, immanent and ultimate 130; justice, pragmatic approach to 127-8; justice in Sri Lankan border village, understandings of 126-8; language rights of citizens 129; legal authority, belief in a just world (BJW) and 128-31; locution at heart of law's grammar 131; Maatram in Sri Lanka 125; retribution, notion of justice transcending 132; Rwanda, gacaca courts in 132; Sierra Leone, Special Court in 132; Sri Lanka, civil war in 125; Sri Lanka, justice system in 125-6; Suriya Women's Development Centre in Sri Lanka 125; transitional justice doctrine, liberal human rights and 132; Trincomalee Women's Network in Sri Lanka 125; victimisation, phenomenon of 130 ; war-related harm to women, lack of prosecutions for 126; women combatants in Ski Lankan civil war 125; Women's Action Network in Sri Lanka 125

Rwanda 216-17, 219; civil war in 35; commemoration in authoritarian contexts, challenges of 44-6; commemorations, alteration of context and recognition of Tutsi victimhood 40-41; first national genocide commemorations 37-40; Gacaca tribunals in 4, 132; génocidaires in 4, 40, 43-4; genocide in, Catholic diocese's recognition of mass atrocities and 39-40; genocide in, commemoration of 35-46; genocide in, Hutu Power and 35-6; genocide in, mass atrocity of 36 ; genocide survivors' associations, government partnership with 38-9; Government of 42; Hutu Power 35-6; inclusive victim consciousness on borders of 173-4; International
Criminal Tribunal for (ICTR) 36, 40; Jenoside yakorewe Abatutsi

("genocide against the Tutsi"). 40;

Kibuye Roman Catholic Church, testimony of survivor of massacre at 38-9; Kigali Genocide Memorial, Victoire Ingabire's speach at (2010) 44; Kigali National Amahoro Stadium, first national genocide commemoration in (1995) 38; Kwibuka 26, launch of 35, 36; memorials, displays of human remains and 42-3; memorials, problem of definitive identification of anonymous dead at 44; memorials in, Vidal's study of 36-7; National Commission for the Fight Against Genocide (CNLG) 35, 36, 38, 40-41, 44-5; "nationalism-within-a-nationalism" in, perpetuation of 36-7; official genocide commemoration, themes in literature on 37; reburials, early commemorative initiatives and 39-40; Rwandan Patriotic Army (RPA) 40, 43; Rwandan Patriotic Front (RPF) 35-6, 37-8, 40; spiritual dangers in memorial sites, perceptions of 43-4; transitional justice in $4-5,14$; the Tutsi, towards commemoration of "1994 genocide against" 40-44; Tutsi RPF, invasion of northern Rwanda by 35

Saguy, T., Tausch, N., Dovidio, J.F. and Pratto, F. 169, 175, 177

Salehi, Miriam 160

Samaraweera, Mangala 54

Sandahiru Maha Seya (Triumphant Pagoda) in Sri Lanka 58

Saravanamuttu, Paikiasothy 14, 51-63

Satkunanathan, Ambika 125

Schaap, Andrew 157, 159

Schclarek, Miguel 114

Schonthal, B. and Walton, M.J. 56

Schröter, Melani 143

Schultz-Kraft, Markus 116-17

Schwarz, Walter 172

Scilingo, Captain Alfredo 112

Search Unit for Missing Persons and the Special Jurisdiction for Peace in

Colombia 111

security guards 94

segregation 3, 69, 73, 74; of black people in South Africa 23-4; emergence of 
new patterns of 67-8; exclusivity, development of new sites of 68; forced segregation 71; new frontier for 73-4; persistence of 68 ; racial segregation $12,68,70,71,74,92$; residential racial segregation 92 ; segregated societies, efficacy of contact interventions in 69; spatial segregation 68 ; territorial segregation 172

Seider, Roger 32

selective silences 7-8, 175-6, 208

self-employment among ex-combatants 145-6

Selim, Y. and Murithi, T. 25, 32

Senanayake, Dudley 57

settler communities, psycho-social situation of 70

shared identity, solidarity and cohesion in 199

shared social identity: political violence and reinforcement of 201-2

Sharp, Dustin N. 155, 157, 158, 160, 164

Shaw, R., Waldorf, L. and Hazan, P. 158,197

Shnabel, N., Belhassen, Y. and Mor, S. 169

Shnabel, N., Halabi, S. and Noor, N. 170,173

Sierra Leone: Special Court in 132; Truth and Reconciliation Commission (TRC) 1-2, 21

Sikkink, Kathryn 118

Silva, K.T., Razaak, M.G.M., Herath, D. and Usoof-Thowfeek, R. 145

Sinhala Buddhism: armed forces of, allegations against 57; politics of 59-60; power hierarchy of 59-60; privileging of Sinhala Buddhist identity in Sri Lanka 59; Sinhala Buddhist-Muslim conflict 55-6

Sinwell, Luke 100

Sirisena, Maithripala 53-4, 55

Skitka, Linda J. 201

social bonds, supportive behaviours and 198

social cooperation, prosocial behaviour and 197

social identities, creation and change of 184

social justice, persistence of racialized segregation and 67-75; apartheid project, implementation of (1948-94) 70-71; apartheid system 70-71; capital flight, "white flight" and 71-2; change, struggle for 67; "contact

hypothesis," Allport's notion of 68-9; contact theory, problem of segregation and 68-70; divisions, South African history of 74; exclusion and new frontier 73-4; exclusivity, development of new sites of 68 ; Freedom Charter (1955) in South Africa 67; gated communities, exclusive estates and 68, 72-3, 73-4; intergroup contact, racialized privilege and 74-5; migration, creation of social justice and 69-70; migration, post-apartheid South Africa migration in 71-3; migration, problem of 70-71, 71-3, 74; post-apartheid case 71-4; post-apartheid cities, movement of capital from 73; post-Rainbow Nation era 74; prejudice reduction, effects of contact on 69; race attitudes 70-71; segregated societies, efficacy of contact interventions in 69; segregation, emergence of new patterns of 67-8; settler community, psycho-social situation of 70; South Africa, post-apartheid reality in 67 ; transformational justice, end of apartbeid and beginning of process of 71; white privilege, persistence of 73-4 social learning, stories of collective resiliance as source for 208 socio-economics $21,25-7,37,72-3,140$, 148, 218; socio-economic redress 92

Sodaro, Amy 37

Solomon, J. and Martin, A. 175

Solomon, Ryan 92, 95, 96-7, 100

South Africa 216-17; accountability, tension between commemoration of past violations and 21; antagonisms, new to post-transition South Africa 93-5; apartheid in, celebration of end of 21-33; apartheid in, effectiveness in moulding minds 23; apartheid in, memory and 22-4; Apartheid Museum in Johannesburg 28; apartheid project, implementation of (1948-94) 22-3; Black Economic Empowerment (BEE) 73; black inferiority, imposition of 23-4; commemoration, transformative potential of 32; corrective moral justice, aim of institution of 22; distributive justice 22; divisions, South 
African history of 74; economic commemoration as act of memorialization 30-32; Freedom Park in Pretoria 28; Greater Gauteng Business Forum (GGBF) 97-8; hate-crime legislation in, lack of 93; Hector Petersen Museum in Soweto 28; Human Rights Commission 92-3; human rights violations, response to legacy of 32-3; Institute for Justice and Reconciliation (IJR) 22, 23; memorialization, economic commemoration as act of 30-32; nation divided during apartheid 23-4; Native Land Act (1913) 22; past in, revisiting TRCs limited engagement with 27-32; post-apartheid reality in 67; post-Rainbow Nation era 74; punitive justice 22; race identities, apartheid system and 24;

Reconciliation Barometer (SARB, IJR) 24, 27; Rhodes Must Fall (RMF) as commemorative movement 28-30; segregation of black people 23-4; shifting paradigms and enduring impact of TRC in 26-7; Sri Lanka government discussions on truth and reconcliation with 52; transitional justice in 3, 4, 14-15; transitional justice in, "negotiated revolution" of non-citizens' rights 91; transitional justice in, origins of 21 ; transitional justice in, transformative function of 24-5; Truth and Reconciliation Commission (TRC) 1-2, 21-2, 25-6, 29, 30, 32, 52, 71, 73, 91-2, 216; Truth and Reconciliation Commission (TRC), establishment of 21-2. see also social justice, persistence of racialized segregation and

South China Morning Post 56

South Sudan, conflict in 172

Special Inquiry and Investigation Unit on post-electoral crisis in Côte d'Ivoire 162

Spini, D., Elcheroth, G. and Fasel, R. 203

Spini, D., Morselli, D. and Elcheroth, G. 11, 203, 204

Spini, Dario 128, 130, 204

Spinola, General Antonio 7

Sri Lanka 204-5, 216-17; All Ceylon Buddhist Congress 54; anti-Muslim sentiment, exacerbation of 56 ;
Aranthalawa, massacre of Buddhist monks in (1987) 55; Archaeological Heritage Management, Presidential Task Force for 58; Buddhist Power Force (BBS) 55, 56; Bureau of the Commissioner General of

Rehabilitation (BCGR) 142-3, 145; Citizens' Commission 206, 207; Civil Defence Force (CDF) 126, 134n6; commemoration, politics of 56-8; Consultative Task Force (CTF) 54; COVID-19 pandemic in 55, 56; Dalada Maligawa (Temple of the Tooth), attack on (1998) 55; displacement of Northern Muslims in 81; Easter Sunday carnage (2019) 59; ethnic cleavages in 79; ethno-religious nationalist fervour 52-3; fault lines, opening up of 55-6; fault lines in, social entrenchment of 79; government discussions about truth and reconcliiations with South Africa 52; Janatha Vimukthi Peramuna (People's Liberation Front) 54; justice system in 125-6; Kandy, Temple of the Tooth in 55, 57; Lessons Learned and Reconciliation Commission (LLRC) 53; Liberation Tigers of Tamil Ealam (LTTE) 206; Liberation Tigers of Tamil Eelam (LTTE) 51, 52, 55, 57, 58, 59-60, 79, 80, 81, 83, 87, $125,140-41,142,144,145,146,148$, $173,176,177$; local government elections (2018), results of 55; Maha Nayake Theras in 57; Missing Persons, Office of 51, 54, 55, 80, 111; Muslim community, post-war conflict with 59; Muslim Marriages and Divorce Act 56; Northern Muslims in 206-7; "One Sri Lanka," notion of 56; Pancha Balavegaya (Five Great Forces) 56-7; People's Alliance for Right to Land 87; post-war treatment of Tamils and Muslims 57-8; post-war victory celebration and unmaking diversity in 51-60; Prevention of Terrorism legislation in 51, 55; privileging of Sinhala Buddhist identity in 59; Puttalam district and Northern Muslims of 80-81; Reparations, Office of 51, 54, 55, 80; Sandahiru Maha Seya (Triumphant Pagoda) 58; Sinhala Buddhism, power hierarchy of 59-60; Sinhala Buddhist 
armed forces, allegations against 57;

Sinhala Buddhist-Muslim conflict 55-6; Sinhala-Tamil ethnic binary in 80-81; Sri Lanka Freedom Party (SLFP) 52, 53; Sri Lanka People's Front (SLPP) 53, 55, 59-60; Tamil Tigers 51, 52, 55, 57, 58, 59-60, 79, $80,81,83,87,125,140-41,142,144$, 145, 146, 148, 173, 176, 177, 206; Tamils in, diaspora community and 108-9; transitional justice in 5, 12 , 14-15; transitional justice in, majority resistance to $58-9$; transitional justice in, short window for 53-5; triumphalist moment in 51-3; United National Party (UNP) 52-3; "unity in diversity," idea of 55-6; wartime human rights violations, accusations of 52; Yahapalanaya (Good

Governance) government 53-4, 55. see also intergenerational justice; rural women, access to law for

Sri Lanka,: contentious history of transitional justice in 80

Srilal, Ranga 56

Sriram, Chandra L. 157

state power 10, 218-19

Statman, James M. 71

Stokke, E. and Wiebelhaus-Brahm, E. 115

Stott, C. and Drury, J. 184

Straus, Scott 35, 44

Subedi, D.B. 141, 143

Subotić, Jelena 159

suffering, inclusive narratives of 169-78;

Armenian genocide, Turkey and 176;

collective victimhood 171-2;

conflict-specific inclusive victim

consciousness 170; demobilization, inclusive victimhood and 175-6, 177; global inclusive victim consciousness 170; group boundaries and identities, redefinition in conflict of 172; group identities in conflict, salience of 172-3; high-power group narratives 175-6; inclusive narratives, risks of 169 ; inclusive narratives of suffering 169-73; inclusive narratives of suffering, selective or universal 174, 175; inclusive narratives of suffering, Sri Lanka perspective 176; inclusive victim consciousness 169-71, 173-5, 176, 177; inclusive victim consciousness, what it is not $170-71$; inclusive victim narratives, defining the reference points for 171-3, 178; inclusive victimhood, pitfalls of 175-7; inclusive victimhood, promise of 173-5; intergroup relations after conflict, effects of inclusive victimhood on 173-5; Israel, Alternative Memorial Day in 169; Israeli-Palestinian conflict 173; low-power group narratives 177; multiple intersecting identities 171 ; multiple intersecting identities, dealing with 171; Northern Ireland, conflict in 170, 171-2, 174-5; Palestine,

Alternative Memorial Day in 169; power differences, inclusive victimhood and 175-7; rebuilding social relationships 169; roles in conflicts, dealing with differences in 171-2; silencing of experiences, inclusive victimhood and 175-6; South Sudan, conflict in 172; transitional justice as inclusive process 169; transitional justice process and 173

Surenthiraraj, E. and De Mel, N. 85, 206

Surenthiraraj, Esther 15, 79-90, 206

Suriya Women's Development Centre in Sri Lanka 125

surveillance of ex-combatants in Sri Lanka 144-5

Sutton, R.M. and Winnard, E.J. 128

Swiss National Science Foundation (SNSF) 15-16, 89, 165n3

Swisspeace 110

Taş, Hakki 191

Tajfel, Henri 184

Tamayo Gomez, Camilo 117

Tamil Tigers in Sri Lanka 125, 206; inclusive narratives of suffering 173 , 176,177 ; intergenerational justice in Sri Lanka 79, 80, 81, 83, 87; reintegration of former combatants 140-41, 142, 144, 145, 146, 148; victory celebration and unmaking of diversity in post-war Sri Lanka 51, 52, $55,57,58,59-60$

Tangri, R. and Southall, R. 73

targeted repression, collective resilience and 202

Teitel, Ruti G. 79, 219

Tekin, S. and Drury, J. 200, 201

Tellez, Juan Fernando 202, 205 
Teodora, A.-T. and Oprescu, S.-O. 107 These Are the Things that Sit with Us (Gobodo-Madikizela, P. et al.) 30

Thiranagama, Sharika 12, 81, 88, 206

Thompson, C. and Carter, R. 23

Thompson, Edward P. 184

Thomson, S. and Nagy, R. 132, 158

Tifara, Kenneth 95

trans-generational experiences, social markers of 85-6

transformational justice: end of apartbeid and beginning of process of 71; legitimacy of, knowledge dimension and 157; turning points and "transformative events," role of 111-13

transitional justice: accountability and order restoration 216; achievements of, de Greiff's reflections on 215; analysis, political power and difficulties of 11-12; central tension (or contradiction) within $21,164-5$, 216; commemoration becoming invasive 3-5; constructive resistance and importance of not knowing in 155-65; continuous becoming of, nurture of 220-21; critical questioning of, relevance of $12-13$; crossroads for 1-6; current position, assessment of 215-16; definitional question 1-2; disenchantments with 6; doctrine of, liberal human rights and 132; domestic processes of, legitimacy of "foreign" actors in 11; dynamics of, complexities of 11-12; ethical debates, necessity for 11 ; expectations of 6 ; extraordinary circumstances, question of focus upon 2-3; framings of past in diasporas' relations to justice at home 109; inadequacy of normal justice systems and 138; as inclusive process 169; intergroup configurations 12 ; justice postponed, societies caught in transition and 3; language of, xenophobia and 97-8; majority resistance in Sri Lanka against 58-9; mechanisms of, instability of 215 ; origins of 21, 79; past injustices, potential for dealing with 218; politics of knowledge and 156-9; practice of 1-2; problem-solving in, de Greiff's call for principled pragmatism in 219; process and suffering, inclusive narratives of 173; process of, laudable nature of setting in motion 13 ; processes of, high stakes of 6 ; in Rwanda 4-5, 14; scales of transformation 10-12; scope of, calls for expansion of 5-6; selective silences 7-8; in South Africa 3, 4, 14-15; special courts and truth commissions, parallel tracks of 217; in Sri Lanka 5, 12, 14-15; strategies for, diaspora engagement with 108; systemic change, discontent in community concerning implementation of 2-3; transformative function of 24-5; transitional justice toolkits (United Nations) 155; truth, memory and quest for shared reality 8-10; unintended consequences, shifts in social ecologies and 11-12;

vocabularies and schemas for, need for innovation in 219 ; war weary communities and planning of 79-80; writing about, aims in 13-15

transnational networking initiatives $112-13$

trench warfare in First World War 203-4, 205

Trincomalee Women's Network in Sri Lanka 125

triumphalist moment in Sri Lanka 51-3

Tromp, Beauregard 92

"truth": memory and quest for shared reality 8-10; search for 156-7, 164; truth-seeking initiatives, development of 115-16

Truth, Memory, and Reconciliation Commission of Colombian Women in the Diaspora 115-16

Truth and Dialogue Commission (CDVR) in Côte d'Ivoire 162, 163-4

Truth and Reconciliation Commission (TRC) in Colombia 117-18

Truth and Reconciliation Commission (TRC) in South Africa 1-2, 21-2, 25-6, 29, 30, 32, 52, 71, 73, 91-2, 216; establishment of 21-2

Truth and Reconciliation Commission (TRC) process, non-citizens' rights and $91-2$

Tshishonga, Ndwakhulu 67

Tunisia 202

Turkey: entrenched divides in 188-9; Justice and Development Party (AKP) 187, 189, 190, 191, 192, 193; Kurdish Workers' Party (PKK) 193; LGBT 


\section{Index}

activism in $183,185,187,189$;

Nationalist Movement Party (MHP)

191; Peoples' Democratic Party

(HDP) in 191, 193; Presidency of

Republic of 192; Republican People's

Party (CHP) 187, 191, 193; Turkish

nationhood, nature of 183 . see also

crowds and transformation of

identities

Turner, John 184

Turner, Rhiannon N. 70

Turner, R.N., Hewstone, M., Voci, A., Paolini, S. and Christ, O. 69

Twali, Michelle Sinayobye 15, 169-82

Twali, M.S., Hameiri, B., Vollhardt, J.R. and Nadler, A. 176

UCT (Cape Town University) 93-4

Uluğ, Ö.M. and Acar, Y.G. 185, 187, 188,189

unilateral victory of government forces in Sri Lanka 141, 144, 147, 176

unintended consequences, shifts in social ecologies and 11-12

United National Party (UNP) in Sri Lanka 52-3

United Nations (UN) 56, 115, 118, 155, 162; Convention on Prevention and Punishment of Crime of Genocide (1948) 36; Côte d'Ivoire 161, 162; General Assembly 45; High Commissioner for Human Rights (UNHCR) 51, 177; Human Rights Council for Côte d'Ivoire 161; Human Rights Council (UNHRC) 53, 54, 59, 161, 216-17; International Day of Reflection on 1994 Genocide Against Tutsi in: Rwanda (April 7th) 45; Security Council 161; UNESCO World Heritage List 45

unity: common experience, common repression and production of 187-90; diversity and 189; "unity in diversity," idea of 55-6

Urban-Walker, Margaret 217

Usoof-Thowfeek, Ramila 15, 138-51, 218

Uwilingiyimana, Agathe 38

Vale, Peter 92, 96

Van Der Westhuizen, Christi 23

Van Hear, N. and Liberatore, G. 109

Van Hoyweghen, Saskia 40

Van Vuuren, Hennie 30, 31-2
Van Zyl, Paul 91

Vélez, M., Carlos, A., Trujillo, A., Moros, L. and Forero, C. 197, 202

Venugopal, Rajesh 127

victim-survivors of conflict-related violence 125

victimhood: inclusive victim consciousness 169-71, 173-5, 176, 177; inclusive victim consciousness, what it is not 170-71; inclusive victimhood, pitfalls of 175-7; inclusive victimhood, promise of 173-5; phenomenon of victimisation 130; power differences, inclusive victimhood and $175-7$

Vidal, Claudine 36, 39-40

Viebach, Julia 36, 37, 38

Villa-Vicencio, Charles 22

violence: attritional forms of 217 ; collective exposure to asymmetric and symmetric, effects of 204; historic violence, collective patterns of 218 ; indiscriminate imposition of 202; longue durée of, attentiveness to 217 ; organized commities and limitation of 201; prevention of, de Greiff's call for principled pragmatism in 219 ; selective violence against civilians 202; transition, application of concept to justice following 220-21

Vishvamadhu case of gang rape in Sri Lanka 126, 133-4n2

Vollhardt, Johanna Ray 15, 169-82, 200

Vollhardt, J.R. and Bilali, R. 173

Vollhardt, J.R. and Twali, M.S. 170

Waldmeir, Patti 25

Waldorf, Lars 138, 139

Walpola, Venerable Rahula 60n2

Warner, R.H., Wohl, M.J.A. and

Branscombe, N.R. 170, 175

Webber, D., Chernikova, M.,

Kruglanski, A.W., Gelfand, M.J. et al. $141,142,143$

Webber, Jeremy 132

Weinstein, Harvey M. 155

Weintraub, Stanley 205

Weisdorf, M. and Sørensen, B.R. 147

white privilege, persistence of 73-4

For Whites Only (Cilliers, C.) 30

Wickremasinghe, Ranil 53-4, 55

Wickremesinhe, R. and Hattotuwa, S. 55 
Wiebelhaus-Brahm, Eric 108, 109, 110, 113,119

Wilkins, I. and Strydom, H. 22

Wilson, Richard A. 158

Winter, Paul 37

Wirathu, Ashin 56

Witting, A.B., Lambert, J. and Wickrama, T. 125

women: displaced populations, women in 125; female ex-combatants, challenges for 146; judicial bias against 126; justice, broken promise for women of 131-2; rural women, access to law for 125 ; war-related harm to women, lack of prosecutions for 126; women combatants in Ski Lankan civil war 125 . see also rural women, access to law for

Women, Trauma and Peacebuilding (WTP) project $134 \mathrm{n} 5$

Women's Action Network in Sri Lanka 125

Woodworth, A. and Fonseka, B. 131 work-related challenges of reintegration 145-6

World Bank 81
World Health Organization (WHO) 56

Wright, S., Aron, A., McLaughlin-Volpe, T. and Ropp, S.A. 69

xenophobia: pervasiveness of 100 ; transition between forms of 96

xenophobic violence: explosion of 92-3; roots of $95-6$

Yahapalanaya (Good Governance) government in Sri Lanka 53-4, 55

Yankelevich, Pablo 110

York, floods in (2015-16) 199

Young, Kathryne M. 131

Young, L. and Park, R. 108

former Yugoslavia 203

Zhou, S., Page-Gould, E., Aron, A., Moyer, A. and Hewstone, M. 69 Zokou, Simplice Seri 163

Zuhair, Ayseha 57, 60n2

Zulu, Andile 95

Zuma, Jacob 52

Zwelithini, King Goodwill 93 
